\title{
Cochrane
}

Library

Cochrane Database of Systematic Reviews

\section{Laparoscopic colposuspension for urinary incontinence in women} (Review)

Freites J, Stewart F, Omar MI, Mashayekhi A, Agur WI

Freites J, Stewart F, Omar MI, Mashayekhi A, Agur WI.

Laparoscopic colposuspension for urinary incontinence in women.

Cochrane Database of Systematic Reviews 2019, Issue 12. Art. No.: CD002239.

DOI: 10.1002/14651858.CD002239.pub4.

www.cochranelibrary.com 
TABLE OF CONTENTS

HEADER 1

ABSTRACT

PLAIN LANGUAGE SUMMARY

SUMMARY OF FINDINGS

BACKGROUND

OBJECTIVES

METHODS

RESULTS

Figure 1.

Figure 2.

Figure 3.

Figure 4.

DISCUSSION

AUTHORS' CONCLUSIONS

ACKNOWLEDGEMENTS

REFERENCES

CHARACTERISTICS OF STUDIES

DATA AND ANALYSES

Analysis 1.1. Comparison 1 Laparoscopic colposuspension versus open colposuspension, Outcome 1 Subjective cure within 18 months.

Analysis 1.2. Comparison 1 Laparoscopic colposuspension versus open colposuspension, Outcome 2 Subjective cure from 18 months up to 5 years.

Analysis 1.3. Comparison 1 Laparoscopic colposuspension versus open colposuspension, Outcome 3 Objective cure within 18 months.

Analysis 1.4. Comparison 1 Laparoscopic colposuspension versus open colposuspension, Outcome 4 Objective cure from 18 months up to 5 years.

Analysis 1.5. Comparison 1 Laparoscopic colposuspension versus open colposuspension, Outcome 5 Objective cure after 5 years.

Analysis 1.6. Comparison 1 Laparoscopic colposuspension versus open colposuspension, Outcome 6 Length of inpatient stay (days).

Analysis 1.7. Comparison 1 Laparoscopic colposuspension versus open colposuspension, Outcome 7 Time to return to daily activities (days).

Analysis 1.8. Comparison 1 Laparoscopic colposuspension versus open colposuspension, Outcome 8 Operation time (minutes).

Analysis 1.9. Comparison 1 Laparoscopic colposuspension versus open colposuspension, Outcome 9 Blood loss (mL). .......... Analysis 1.10. Comparison 1 Laparoscopic colposuspension versus open colposuspension, Outcome 10 Duration of catheterisation (days).

Analysis 1.11. Comparison 1 Laparoscopic colposuspension versus open colposuspension, Outcome 11 Perioperative complications (number of events).

Analysis 1.12. Comparison 1 Laparoscopic colposuspension versus open colposuspension, Outcome 12 Bladder perforations.

Analysis 1.13. Comparison 1 Laparoscopic colposuspension versus open colposuspension, Outcome 13 De novo detrusor overactivity (urodynamic diagnosis).

Analysis 1.14. Comparison 1 Laparoscopic colposuspension versus open colposuspension, Outcome 14 Voiding dysfunction within 18 months.

Analysis 1.15. Comparison 1 Laparoscopic colposuspension versus open colposuspension, Outcome 15 Quality of life. .......... Analysis 2.1. Comparison 2 Laparoscopic colposuspension versus midurethral sling procedures, Outcome 1 Subjective cure within 18 months.

Analysis 2.2. Comparison 2 Laparoscopic colposuspension versus midurethral sling procedures, Outcome 2 Number of women with de novo urgency symptoms.

Analysis 2.3. Comparison 2 Laparoscopic colposuspension versus midurethral sling procedures, Outcome 3 Incontinence episodes per week.

Analysis 2.4. Comparison 2 Laparoscopic colposuspension versus midurethral sling procedures, Outcome 4 Objective cure within 18 months. 
Analysis 2.5. Comparison 2 Laparoscopic colposuspension versus midurethral sling procedures, Outcome 5 Length of inpatient stay (days).

Analysis 2.6. Comparison 2 Laparoscopic colposuspension versus midurethral sling procedures, Outcome 6 Time to return to daily activities (days).

Analysis 2.7. Comparison 2 Laparoscopic colposuspension versus midurethral sling procedures, Outcome 7 Operation time (mins).

Analysis 2.8. Comparison 2 Laparoscopic colposuspension versus midurethral sling procedures, Outcome 8 Perioperative complications (number of events).

Analysis 2.9. Comparison 2 Laparoscopic colposuspension versus midurethral sling procedures, Outcome 9 De novo detrusor overactivity (urodynamic diagnosis) within 18 months.

Analysis 2.10. Comparison 2 Laparoscopic colposuspension versus midurethral sling procedures, Outcome 10 Voiding dysfunction within 18 months.

Analysis 3.1. Comparison 3 Laparoscopic colposuspension with sutures versus laparoscopic colposuspension with mesh and staples, Outcome 1 Subjective cure within 18 months.

Analysis 3.2. Comparison 3 Laparoscopic colposuspension with sutures versus laparoscopic colposuspension with mesh and staples, Outcome 2 Objective cure within 18 months.

Analysis 3.3. Comparison 3 Laparoscopic colposuspension with sutures versus laparoscopic colposuspension with mesh and staples, Outcome 3 Perioperative complications.

Analysis 3.4. Comparison 3 Laparoscopic colposuspension with sutures versus laparoscopic colposuspension with mesh and staples, Outcome 4 De novo detrusor overactivity within 18 months.

ADDITIONAL TABLES

APPENDICES

WHAT'S NEW

HISTORY

CONTRIBUTIONS OF AUTHORS

DECLARATIONS OF INTEREST

SOURCES OF SUPPORT

DIFFERENCES BETWEEN PROTOCOL AND REVIEW 
[Intervention Review]

\section{Laparoscopic colposuspension for urinary incontinence in women}

Jawad Freites $^{1}$, Fiona Stewart ${ }^{2}$, Muhammad Imran Omar ${ }^{3,4}$, Atefeh Mashayekhi², Wael I Agur ${ }^{5}$

1Department of Obstetrics \& Gynaecology, York Hospitals NHS Foundation Trust, Scarborough, UK. ${ }^{2}$ c/o Cochrane Incontinence, Population Health Sciences Institute, Newcastle University, Newcastle upon Tyne, UK. 3European Association of Urology, Arnhem, Netherlands. ${ }^{4}$ Academic Urology Unit, University of Aberdeen, Aberdeen, UK. ${ }^{5}$ School of Medicine, Dentistry and Nursing, University of Glasgow, Glasgow, UK

Contact address: Wael I Agur, School of Medicine, Dentistry and Nursing, University of Glasgow, Glasgow, G12 8QQ, UK. Wael.Agur@glasgow.ac.uk.

Editorial group: Cochrane Incontinence Group

Publication status and date: New search for studies and content updated (no change to conclusions), published in Issue 12, 2019.

Citation: Freites J, Stewart F, Omar MI, Mashayekhi A, Agur WI. Laparoscopic colposuspension for urinary incontinence in women. Cochrane Database of Systematic Reviews 2019, Issue 12. Art. No.: CD002239. DOI: 10.1002/14651858.CD002239.pub4.

Copyright ( 2019 The Cochrane Collaboration. Published by John Wiley \& Sons, Ltd.

\section{A B S T R A C T}

\section{Background}

Laparoscopic colposuspension was one of the first minimal access operations for treating stress urinary incontinence in women, with the presumed advantages of shorter hospital stays and quicker return to normal activities.

This Cochrane Review was last updated in 2010.

\section{Objectives}

To assess the effects of laparoscopic colposuspension for urinary incontinence in women; and summarise the principal findings of relevant economic evaluations of these interventions.

\section{Search methods}

We searched the Cochrane Incontinence Specialised Register (22 May 2019), which contains trials identified from CENTRAL, MEDLINE, MEDLINE In-Process, MEDLINE Epub Ahead of Print, CINAHL, ClinicalTrials.gov, WHO ICTRP and handsearching of journals and conference proceedings.

\section{Selection criteria}

Randomised controlled trials of women with urinary incontinence that included laparoscopic surgery in at least one arm.

\section{Data collection and analysis}

We independently extracted data from eligible trials, assessed risk of bias and implemented GRADE.

\section{Main results}

We included 26 trials involving 2271 women.

Thirteen trials (1304 women) compared laparoscopic colposuspension to open colposuspension and nine trials (412 women) to midurethral sling procedures. One trial (161 women) compared laparoscopic colposuspension with one suture to laparoscopic colposuspension with two sutures; and three trials ( 261 women) compared laparoscopic colposuspension with sutures to laparoscopic colposuspension with mesh and staples. The majority of trials did not follow up participants beyond 18 months. Overall, there was unclear risk of selection, performance and detection bias and generally low risk of attrition and reporting bias. 
There is little difference between laparoscopic colposuspension using sutures and open colposuspension for subjective cure within 18 months (risk ratio (RR) 1.04, 95\% confidence interval ( $\mathrm{Cl}$ ) 0.99 to 1.08 ; 6 trials, 755 women; high-quality evidence). We are uncertain whether laparoscopic colposuspension using mesh and staples is better or worse than open colposuspension for subjective cure within 18 months (RR $0.75,95 \% \mathrm{Cl} 0.61$ to $0.93 ; 3$ trials, 362 women; very low-quality evidence) or whether there is a greater risk of repeat continence surgery with laparoscopic colposuspension. Laparoscopic colposuspension may have a lower risk of perioperative complications (RR $0.67,95 \% \mathrm{Cl}$ 0.47 to 0.94 ; 11 trials, 1369 women; low-quality evidence). There may be similar or higher rates of bladder perforations with laparoscopic colposuspension (RR 1.72, 95\% $\mathrm{Cl} 0.90$ to 3.29; 10 trials, 1311 women; moderate-quality evidence). Rates for de novo detrusor overactivity (RR 1.29, 95\% Cl 0.72 to 2.30; 5 trials, 472 women) and voiding dysfunction (RR 0.81, 95\% Cl 0.50 to 1.31; 5 trials, 507 women) may be similar but we are uncertain due to the wide confidence interval. Five studies reported on quality of life but we could not synthesise the data.

There may be little difference between laparoscopic colposuspension using sutures and tension-free vaginal tape (TVT) for subjective cure within 18 months (RR 1.01, 95\% Cl 0.88 to 1.16; 4 trials, 256 women; low-quality evidence) or between laparoscopic colposuspension using mesh and staples and TVT (RR $0.71,95 \% \mathrm{Cl} 0.55$ to $0.91 ; 1$ trial, 121 women; low-quality evidence). For laparoscopic colposuspension compared with midurethral slings, there may be lower rates of repeat continence surgery (RR $0.40,95 \% \mathrm{Cl} 0.04$ to $3.62 ; 1$ trial, 70 women; lowquality evidence) and similar risk of perioperative complications (RR $0.99,95 \% \mathrm{Cl} 0.60$ to $1.64 ; 7$ trials, 514 women; low-quality evidence) but we are uncertain due to the wide confidence intervals. There may be little difference in terms of de novo detrusor overactivity (RR $0.80,95 \% \mathrm{Cl} 0.34$ to 1.88 ; 4 trials, 326 women; low-quality evidence); and probably little difference in terms of voiding dysfunction (RR 1.06 , $95 \% \mathrm{Cl} 0.47$ to $2.41 ; 5$ trials, 412 women; moderate-quality evidence) although we are uncertain due to the wide confidence interval. Five studies reported on quality of life but we could not synthesise the data. No studies reported on bladder perforations.

Low-quality evidence indicates that there may be higher subjective cure rates within 18 months with two sutures compared to one suture (RR 1.37, $95 \% \mathrm{Cl} 1.14$ to $1.64 ; 1$ trial, 158 women). Comparing one suture and two sutures, one suture may have lower rates of repeat continence surgery (RR $0.35,95 \% \mathrm{Cl} 0.01$ to $8.37 ; 1$ trial, 157 women) and similar risk of perioperative complications (RR $0.88,95 \% \mathrm{Cl} 0.45$ to 1.70 ) but we are uncertain due to the wide $95 \% \mathrm{Cls}$. There may be higher rates of voiding dysfunction with one suture compared to two sutures (RR 2.82; $95 \% \mathrm{Cl} 0.30$ to 26.54; 1 trial, 158 women; low-quality evidence), but we are uncertain due to the wide confidence interval. This trial did not report bladder perforations, de novo detrusor overactivity or quality of life.

We are uncertain whether laparoscopic colposuspension with sutures is better or worse for subjective cure within 18 months compared to mesh and staples (RR 1.24, 95\% Cl 0.96 to 1.59; 2 trials, 180 women; very low-quality evidence) or in terms of repeat continence surgery (RR $0.97,95 \% \mathrm{Cl} 0.06$ to $14.91 ; 1$ trial, 69 women; very low-quality evidence). Laparoscopic colposuspension with sutures may increase the number of perioperative complications compared to mesh and staples (RR 1.94, 95\% Cl 1.09 to 3.48; 3 trials, 260 women; low-quality evidence) but rates of de novo detrusor overactivity may be similar (RR $0.72,95 \% \mathrm{Cl} 0.17$ to $3.06 ; 2$ trials, 122 women; low-quality evidence), however, we are uncertain due to the wide confidence interval. None of the studies reported bladder perforations, voiding dysfunction or quality of life.

\section{Authors' conclusions}

The data indicate that, in terms of subjective cure of incontinence within 18 months, there is probably little difference between laparoscopic colposuspension and open colposuspension, or between laparoscopic colposuspension and midurethral sling procedures. Much of the evidence is low quality, meaning that a considerable degree of uncertainty remains about laparoscopic colposuspension. Future trials should recruit adequate numbers, conduct long-term follow-up and measure clinically important outcomes.

A brief economic commentary identified three studies. We have not quality-assessed them and they should be interpreted in light of the findings on clinical effectiveness.

\section{PLAIN LANGUAGE SUMMARY}

\section{Keyhole (laparoscopic) surgery through the abdomen for treating urinary incontinence in women}

\section{Review question}

We investigated whether keyhole surgery (laparoscopic colposuspension) was better than other types of surgery to treat urinary incontinence (leakage of urine) in women. We also compared different methods of laparoscopic colposuspension to each other.

\section{Background}

Urinary incontinence is a common debilitating problem for many women. Around a third of women of child-bearing age leak urine during physical exertion or when they cough, laugh or sneeze. When urinary incontinence persists after non-surgical treatment, surgery is often recommended. Laparoscopic colposuspension is an operation carried out through a small incision in the abdomen to hold and support the tissues around the neck of the bladder.

\section{How up-to-date is this review?}

The evidence is current up to 22 May 2019. 


\section{Study characteristics}

We identified 26 trials with 2271 women that either compared laparoscopic colposuspension with other types of surgery for managing urinary incontinence or compared different approaches of laparoscopic colposuspension. All the trials followed up the women for at least 18 months after surgery, with some trials lasting around five years. We looked at the robustness of each trial's methods and the number of women involved to judge the quality of the evidence they presented.

\section{Key results}

High-quality evidence means that we are confident that laparoscopic colposuspension with sutures (keyhole surgery with stitches) is as effective as open colposuspension (traditional surgery) for curing incontinence in the short term (up to 18 months after surgery). However, we are not sure whether there are fewer risks of complications during and after surgery with laparoscopic or open colposuspension.

Procedures using a midurethral sling (a sort of hammock that supports the neck of the bladder) may be as effective as laparoscopic colposuspension in curing urinary incontinence in the short term and avoiding surgical complications. Women may be less likely to need repeat surgery with a 'sling' than with laparoscopic colposuspension. We are not sure about these results because the evidence was low quality.

Laparoscopic colposuspension with two sutures may be better than with one suture for curing urinary incontinence in the short term, and for reducing the risk of voiding dysfunction and the need for more surgery, but there may be little difference between laparoscopic colposuspension with two sutures or with one in terms of surgical complications. Again, we are not sure about these results because the evidence was low quality.

We are very uncertain whether laparoscopic colposuspension with mesh and staples is better than open colposuspension or laparoscopic colposuspension with sutures for curing urinary incontinence. We are also very uncertain whether women who have laparoscopic colposuspension with mesh and staples or with sutures need less repeat surgery. We are very uncertain about the results because the quality of evidence was very low.

The evidence that we found relating to the effect of laparoscopic colposuspension on quality of life was inconclusive and could not be generalised.

\section{Quality of the evidence}

In general, the quality of the evidence was low. This means that we cannot be certain about the overall effectiveness of laparoscopic colposuspension compared to other treatments for urinary incontinence due to low numbers of women participating in the trials, risk of bias, and differences between trials in the statistical results. 
SUMMARY OF FINDINGS

Summary of findings for the main comparison. Laparoscopic colposuspension compared to open colposuspension for urinary incontinence in women

Laparoscopic colposuspension compared to open colposuspension for urinary incontinence in women

Patient or population: women with urinary incontinence

Setting: secondary care

Intervention: laparoscopic colposuspension

Comparison: open colposuspension

\begin{tabular}{|c|c|c|c|c|c|c|}
\hline \multirow[t]{2}{*}{ Outcomes } & \multicolumn{2}{|c|}{ Anticipated absolute effects ${ }^{\star}(95 \% \mathrm{Cl})$} & \multirow{2}{*}{$\begin{array}{l}\text { Relative ef- } \\
\text { fect } \\
(95 \% \mathrm{CI})\end{array}$} & \multirow{2}{*}{$\begin{array}{l}\text { № of partici- } \\
\text { pants } \\
\text { (studies) }\end{array}$} & \multirow{2}{*}{$\begin{array}{l}\text { Quality of the } \\
\text { evidence } \\
\text { (GRADE) }\end{array}$} & \multirow[t]{2}{*}{ Comments } \\
\hline & $\begin{array}{l}\text { Risk with open } \\
\text { colposuspen- } \\
\text { sion }\end{array}$ & $\begin{array}{l}\text { Risk with laparoscopic } \\
\text { colposuspension }\end{array}$ & & & & \\
\hline \multirow{2}{*}{$\begin{array}{l}\text { Subjective cure within } 18 \text { months: } \\
\text { laparoscopic colposuspension using } \\
\text { sutures }\end{array}$} & \multicolumn{2}{|l|}{ Study population } & \multirow{2}{*}{$\begin{array}{l}\text { RR } 1.04 \\
\text { (0.99 to } 1.08)\end{array}$} & \multirow{2}{*}{$\begin{array}{l}755 \\
\text { (6 RCTs) }\end{array}$} & \multirow{2}{*}{$\begin{array}{l}\oplus \oplus \oplus \oplus \\
\text { High }\end{array}$} & \\
\hline & 789 per 1000 & $\begin{array}{l}821 \text { per } 1000 \\
\text { (781 to } 852)\end{array}$ & & & & \\
\hline \multirow{2}{*}{$\begin{array}{l}\text { Subjective cure within } 18 \text { months: } \\
\text { laparoscopic colposuspension using } \\
\text { mesh and staples }\end{array}$} & \multicolumn{2}{|l|}{ Study population } & \multirow{2}{*}{$\begin{array}{l}\text { RR } 0.75 \\
\text { (0.61 to } 0.93)\end{array}$} & \multirow{2}{*}{$\begin{array}{l}362 \\
\text { (3 RCTs) }\end{array}$} & \multirow{2}{*}{$\begin{array}{l}\oplus \ominus \ominus \ominus \\
\text { Very lowa,b,c }\end{array}$} & \\
\hline & 906 per 1000 & $\begin{array}{l}679 \text { per } 1000 \\
(552 \text { to } 842)\end{array}$ & & & & \\
\hline Quality of life & \multicolumn{2}{|l|}{-} & - & $\begin{array}{l}742 \\
\text { (5 RCTs) }\end{array}$ & - & $\begin{array}{l}\text { Trials collected QoL evidence } \\
\text { using a range of validated ques- } \\
\text { tionnaires. Data were unsuit- } \\
\text { able for synthesis and indicated } \\
\text { little evidence of a difference } \\
\text { between the groups. }\end{array}$ \\
\hline $\begin{array}{l}\text { Repeat continence surgery: } \\
\text { follow-up } 1 \text { year }\end{array}$ & & & & $\begin{array}{l}60 \\
(1 \mathrm{RCT})\end{array}$ & & $\begin{array}{l}\text { At } 5 \text { years } 3 / 30 \text { in the laparo- } \\
\text { scopic colposuspension group } \\
\text { and } 0 / 30 \text { in the open colposus- } \\
\text { pension group had repeat con- } \\
\text { tinence surgery. }\end{array}$ \\
\hline \multirow[t]{2}{*}{$\begin{array}{l}\text { Adverse effects: perioperative com- } \\
\text { plications (number of events) }\end{array}$} & \multicolumn{2}{|l|}{ Study population } & \multirow[t]{2}{*}{$\begin{array}{l}\text { RR } 0.67 \\
\text { (0.47 to } 0.94)\end{array}$} & \multirow[t]{2}{*}{$\begin{array}{l}1369 \\
(11 \mathrm{RCTS})\end{array}$} & \multirow{2}{*}{$\begin{array}{l}\oplus \oplus \ominus \ominus \\
\text { Lowb,d }\end{array}$} & \\
\hline & 174 per 1000 & 117 per 1000 & & & & \\
\hline
\end{tabular}

174 per $1000 \quad 117$ per 1000 


\begin{tabular}{|c|c|c|c|c|c|c|}
\hline \multirow{3}{*}{\multicolumn{2}{|c|}{$\begin{array}{l}\text { Adver } \\
\text { tions }\end{array}$}} & \multicolumn{2}{|r|}{ (82 to 164 ) } & \multirow{2}{*}{$\begin{array}{l}\text { RR } 1.72 \\
(0.90 \text { to } 3.29)\end{array}$} & \multirow{2}{*}{$\begin{array}{l}1311 \\
\text { (10 RCTs) }\end{array}$} & \multirow{3}{*}{$\begin{array}{l}\oplus \oplus \oplus \ominus \\
\text { Moderate }\end{array}$} \\
\hline & & \multicolumn{2}{|c|}{ Study population } & & & \\
\hline & & 18 per 1000 & $\begin{array}{l}30 \text { per } 1000 \\
(16 \text { to } 58)\end{array}$ & & & \\
\hline & \multirow{2}{*}{$\begin{array}{l}\text { Adverse effects: de novo detrusor } \\
\text { overactivity (urodynamic diagnosis) } \\
\text { Follow-up: } 18 \text { months }\end{array}$} & \multicolumn{2}{|c|}{ Study population } & \multirow{2}{*}{$\begin{array}{l}\text { RR } 1.29 \\
(0.72 \text { to } 2.30)\end{array}$} & \multirow{2}{*}{$\begin{array}{l}472 \\
\text { (5 RCTs) }\end{array}$} & \multirow{2}{*}{$\begin{array}{l}\oplus \oplus \oplus \ominus \\
\text { Moderate }\end{array}$} \\
\hline$\stackrel{0}{\stackrel{0}{\circ}} \stackrel{3}{\stackrel{0}{0}}$ & & 75 per 1000 & $\begin{array}{l}96 \text { per } 1000 \\
(54 \text { to } 172)\end{array}$ & & & \\
\hline 预. & \multirow{2}{*}{$\begin{array}{l}\text { Adverse effects: voiding dysfunc- } \\
\text { tion }\end{array}$} & \multicolumn{2}{|c|}{ Study population } & \multirow{2}{*}{$\begin{array}{l}\text { RR } 0.81 \\
(0.50 \text { to } 1.31)\end{array}$} & \multirow{2}{*}{$\begin{array}{l}507 \\
\text { (5 RCTs) }\end{array}$} & \multirow{2}{*}{$\begin{array}{l}\oplus \oplus \oplus \ominus \\
\text { Moderate }\end{array}$} \\
\hline 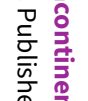 & & 109 per 1000 & $\begin{array}{l}88 \text { per } 1000 \\
\text { (54 to } 142)\end{array}$ & & & \\
\hline
\end{tabular}

${ }^{\star}$ The risk in the intervention group (and its $95 \%$ confidence interval) is based on the assumed risk in the comparison group and the relative effect of the intervention (and its $95 \% \mathrm{Cl})$.

Cl: confidence interval; QoL: quality of life; RCT: randomised controlled trial; RR: risk ratio

\section{GRADE Working Group grades of evidence}

High quality: further research is very unlikely to change our confidence in the estimate of effect.

Moderate quality: further research is likely to have an important impact on our confidence in the estimate of effect and may change the estimate.

Low quality: further research is very likely to have an important impact on our confidence in the estimate of effect and is likely to change the estimate.

Very low quality: we are very uncertain about the estimate.

aDowngraded one level due to unclear risk of selection bias.

bDowngraded one level for inconsistency due to unexplained statistical heterogeneity.

cDowngraded one level for imprecision due to small sample sizes and few trials.

dDowngraded one level due to unclear risk of selection, detection and performance bias.

eDowngraded one level for imprecision due to wide $95 \% \mathrm{Cls}$, indicating high uncertainty about possible benefit or harm.

\section{Summary of findings 2 . Laparoscopic colposuspension compared to midurethral sling procedures for urinary incontinence in women}

Laparoscopic colposuspension compared to midurethral sling procedures for urinary incontinence in women

Patient or population: women with urinary incontinence

Setting: secondary care

Intervention: laparoscopic colposuspension

Comparison: midurethral sling procedures 


\begin{tabular}{|c|c|c|c|c|c|c|c|}
\hline \multirow{2}{*}{\multicolumn{2}{|c|}{ Oे }} & \multicolumn{2}{|c|}{ Anticipated absolute effects ${ }^{\star}(95 \% \mathrm{Cl})$} & \multirow{2}{*}{$\begin{array}{l}\text { Relative ef- } \\
\text { fect } \\
(95 \% \mathrm{CI})\end{array}$} & \multirow{2}{*}{$\begin{array}{l}\text { № of partici- } \\
\text { pants } \\
\text { (studies) }\end{array}$} & \multirow{2}{*}{$\begin{array}{l}\text { Quality of the } \\
\text { evidence } \\
\text { (GRADE) }\end{array}$} & \multirow[t]{2}{*}{ Comments } \\
\hline & & $\begin{array}{l}\text { Risk with midurethral } \\
\text { sling procedures }\end{array}$ & $\begin{array}{l}\text { Risk with laparoscopic colpo- } \\
\text { suspension }\end{array}$ & & & & \\
\hline : & \multirow{2}{*}{$\begin{array}{l}\text { Subjective cure within } \mathbf{1 8} \\
\text { months: laparoscopic colposus- } \\
\text { pension using sutures versus TVT }\end{array}$} & \multicolumn{2}{|l|}{ Study population } & \multirow{2}{*}{$\begin{array}{l}\text { RR } 1.01 \\
\text { (0.88 to } 1.16)\end{array}$} & \multirow{2}{*}{$\begin{array}{l}256 \\
\text { (4 RCTs) }\end{array}$} & \multirow{2}{*}{$\begin{array}{l}\oplus \oplus \oplus \ominus \\
\operatorname{Low}^{a}, \mathrm{~b}\end{array}$} & \\
\hline 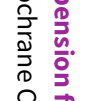 & & 741 per 1000 & $\begin{array}{l}748 \text { per } 1000 \\
\text { (652 to } 859)\end{array}$ & & & & \\
\hline 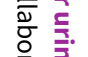 & \multirow{2}{*}{$\begin{array}{l}\text { Subjective cure within } \mathbf{1 8} \\
\text { months: laparoscopic colposus- } \\
\text { pension using mesh versus TVT }\end{array}$} & \multicolumn{2}{|l|}{ Study population } & \multirow{2}{*}{$\begin{array}{l}\text { RR } 0.71 \\
\text { (0.55 to } 0.91)\end{array}$} & \multirow{2}{*}{$\begin{array}{l}121 \\
(1 \mathrm{RCT})\end{array}$} & \multirow{2}{*}{$\begin{array}{l}\oplus \oplus \odot \ominus \\
\text { Lowc }^{c}\end{array}$} & \\
\hline 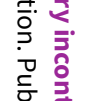 & & 829 per 1000 & $\begin{array}{l}588 \text { per } 1000 \\
\text { (456 to } 754)\end{array}$ & & & & \\
\hline 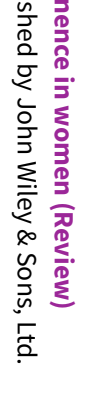 & Quality of life & - & & - & $\begin{array}{l}385 \\
(5 \mathrm{RCTS})\end{array}$ & - & $\begin{array}{l}\text { Trials collected } \\
\text { QoL evidence using } \\
\text { a range of validat- } \\
\text { ed questionnaires. } \\
\text { Data were unsuit- } \\
\text { able for synthesis } \\
\text { and indicated little } \\
\text { evidence of a dif- } \\
\text { ference between } \\
\text { the groups. }\end{array}$ \\
\hline & \multirow[t]{2}{*}{$\begin{array}{l}\text { Repeat continence surgery: } \\
\text { follow-up } 1 \text { year }\end{array}$} & \multicolumn{2}{|c|}{$\begin{array}{l}1 / 32 \text { women in the laparoscopic colposuspension group } \\
\text { and } 3 / 38 \text { women in the midurethral slings group had re- } \\
\text { peat continence surgery. }\end{array}$} & \multirow[t]{2}{*}{$\begin{array}{l}\text { RR } 0.40 \\
\text { (0.04 to } 3.62)\end{array}$} & \multirow[t]{2}{*}{$\begin{array}{l}70 \\
(1 \mathrm{RCT})\end{array}$} & \multirow[t]{2}{*}{$\begin{array}{l}\oplus \oplus \ominus \ominus \\
\text { Lowc }\end{array}$} & \\
\hline & & 79 per 1000 & $\begin{array}{l}32 \text { per } 1000 \\
\text { ( } 3 \text { to } 286)\end{array}$ & & & & \\
\hline & \multirow{2}{*}{$\begin{array}{l}\text { Adverse effects: perioperative } \\
\text { complications (number of events) }\end{array}$} & \multicolumn{2}{|l|}{ Study population } & \multirow{2}{*}{$\begin{array}{l}\text { RR } 0.99 \\
\text { (0.60 to } 1.64)\end{array}$} & \multirow{2}{*}{$\begin{array}{l}514 \\
(7 \mathrm{RCTs})\end{array}$} & \multirow{2}{*}{$\begin{array}{l}\oplus \oplus \ominus \ominus \\
\text { Lowb,d }\end{array}$} & \\
\hline & & 99 per 1000 & $\begin{array}{l}98 \text { per } 1000 \\
(59 \text { to } 162)\end{array}$ & & & & \\
\hline & $\begin{array}{l}\text { Adverse effects: bladder perfora- } \\
\text { tions }\end{array}$ & - & - & - & - & - & Not reported. \\
\hline & \multirow{2}{*}{$\begin{array}{l}\text { Adverse effects: de novo detrusor } \\
\text { overactivity (urodynamic diagno- } \\
\text { sis) } \\
\text { Follow-up: } 18 \text { months }\end{array}$} & \multicolumn{2}{|l|}{ Study population } & \multirow{2}{*}{$\begin{array}{l}\text { RR } 0.80 \\
\text { (0.34 to } 1.88)\end{array}$} & \multirow{2}{*}{$\begin{array}{l}326 \\
(4 \mathrm{RCTs})\end{array}$} & \multirow{2}{*}{$\begin{array}{l}\oplus \oplus \ominus \ominus \\
\text { Lowb,d }\end{array}$} & \\
\hline a & & 62 per 1000 & 50 per 1000 & & & & \\
\hline
\end{tabular}




\begin{tabular}{|c|c|c|c|c|c|}
\hline \multicolumn{6}{|c|}{ (21 to 117 ) } \\
\hline \multirow{2}{*}{$\begin{array}{l}\text { Adverse effects: voiding dysfunc- } \\
\text { tion }\end{array}$} & Study popu & & \multirow{2}{*}{$\begin{array}{l}\text { RR } 1.06 \\
\text { (0.47 to } 2.41)\end{array}$} & \multirow{2}{*}{$\begin{array}{l}412 \\
\text { (5 RCTs) }\end{array}$} & \multirow{2}{*}{$\begin{array}{l}\oplus \oplus \oplus \ominus \\
\text { Moderateb }\end{array}$} \\
\hline & 41 per 1000 & $\begin{array}{l}44 \text { per } 1000 \\
(19 \text { to } 99)\end{array}$ & & & \\
\hline
\end{tabular}

${ }^{\star}$ The risk in the intervention group (and its $95 \%$ confidence interval) is based on the assumed risk in the comparison group and the relative effect of the intervention (and its $95 \% \mathrm{Cl})$.

Cl: confidence interval; QoL: quality of life; RCT: randomised controlled trial; RR: risk ratio; TVT: tension-free vaginal tape

\section{GRADE Working Group grades of evidence}

High quality: further research is very unlikely to change our confidence in the estimate of effect.

Moderate quality: further research is likely to have an important impact on our confidence in the estimate of effect and may change the estimate.

Low quality: further research is very likely to have an important impact on our confidence in the estimate of effect and is likely to change the estimate.

Very low quality: we are very uncertain about the estimate.

aDowngraded one level due to unclear risk of bias in most domains.

bDowngraded one level: small sample size and the confidence interval includes the possibility of no important effect, and also an important harm.

'Downgraded two levels due to serious imprecision: single trial with small sample size.

dDowngraded one level due to unclear risk of selection, performance and detection bias.

Summary of findings 3. Laparoscopic colposuspension with one suture compared to laparoscopic colposuspension with two sutures for urinary incontinence in women

Laparoscopic colposuspension with one suture compared to laparoscopic colposuspension with two sutures for urinary incontinence in women

Patient or population: women with urinary incontinence

Setting: secondary care

Intervention: laparoscopic colposuspension with one suture

Comparison: laparoscopic colposuspension with two sutures

\begin{tabular}{|c|c|c|c|c|c|c|}
\hline \multirow[t]{2}{*}{ Outcomes } & \multicolumn{2}{|c|}{ Anticipated absolute effects ${ }^{\star}(95 \% \mathrm{Cl})$} & \multirow{2}{*}{$\begin{array}{l}\text { Relative effect } \\
(95 \% \mathrm{CI})\end{array}$} & \multirow{2}{*}{$\begin{array}{l}\text { № of partici- } \\
\text { pants } \\
\text { (studies) }\end{array}$} & \multirow{2}{*}{$\begin{array}{l}\text { Quality of the } \\
\text { evidence } \\
\text { (GRADE) }\end{array}$} & \multirow[t]{2}{*}{ Comments } \\
\hline & $\begin{array}{l}\text { Risk with laparoscopic col- } \\
\text { posuspension with two su- } \\
\text { tures }\end{array}$ & $\begin{array}{l}\text { Risk with laparoscopic colposus- } \\
\text { pension with one suture }\end{array}$ & & & & \\
\hline \multirow{2}{*}{$\begin{array}{l}\text { Subjective cure within } 18 \\
\text { months }\end{array}$} & Study population & & \multirow{2}{*}{$\begin{array}{l}\text { RR } 1.37 \\
\text { (1.14 to } 1.64)\end{array}$} & \multirow{2}{*}{$\begin{array}{l}158 \\
(1 \mathrm{RCT})\end{array}$} & \multirow{2}{*}{$\begin{array}{l}\oplus \oplus \ominus \ominus \\
\text { Lowa,b }^{a}\end{array}$} & \\
\hline & 889 per 1000 & 1000 per 1000 & & & & \\
\hline
\end{tabular}




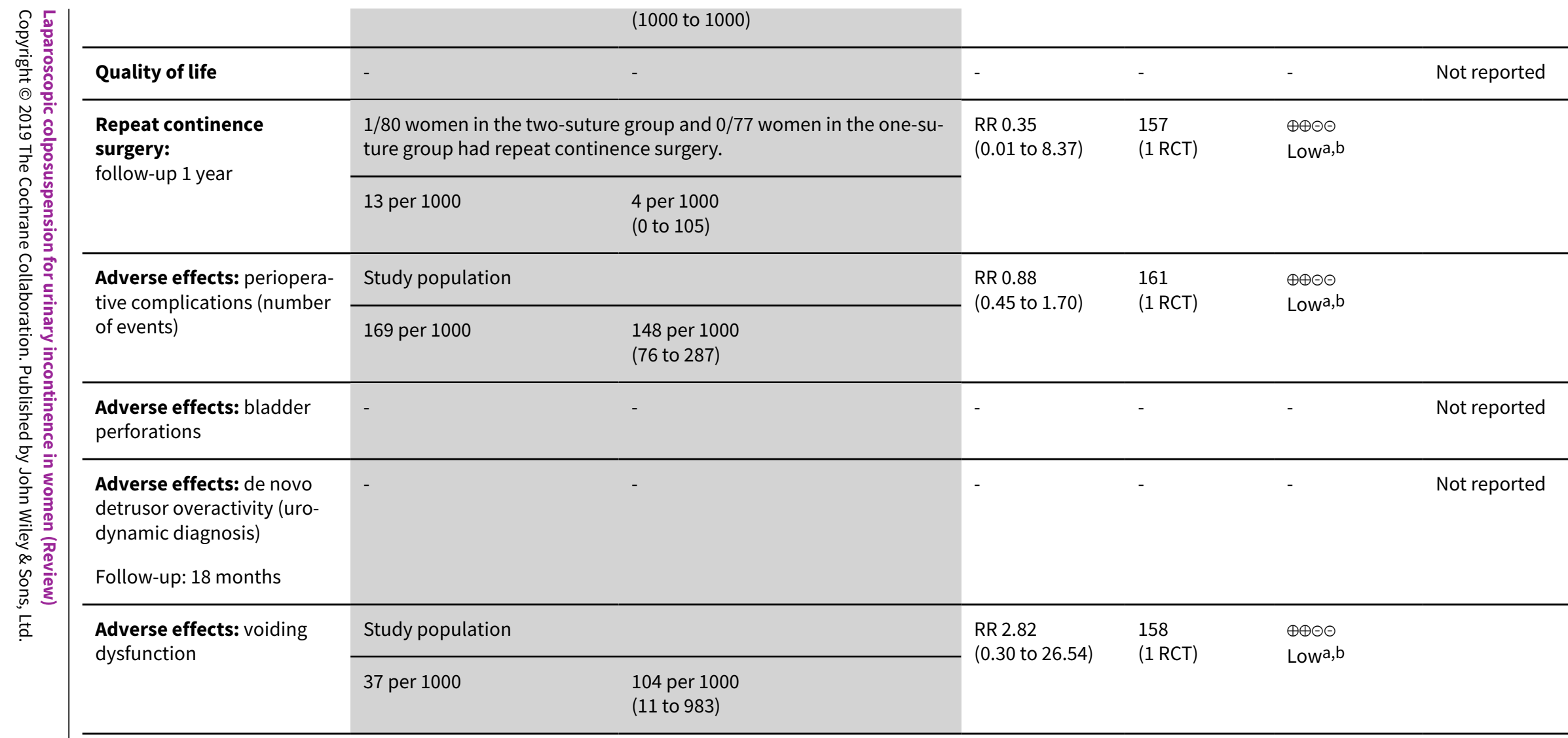

${ }^{*}$ The risk in the intervention group (and its $95 \%$ confidence interval) is based on the assumed risk in the comparison group and the relative effect of the intervention (and its $95 \% \mathrm{Cl})$.

Cl: confidence interval; QoL: quality of life; RCT: randomised controlled trial; RR: risk ratio

\section{GRADE Working Group grades of evidence}

High quality: further research is very unlikely to change our confidence in the estimate of effect.

Moderate quality: further research is likely to have an important impact on our confidence in the estimate of effect and may change the estimate.

Low quality: further research is very likely to have an important impact on our confidence in the estimate of effect and is likely to change the estimate.

Very low quality: we are very uncertain about the estimate.

aDowngraded one level due to serious imprecision: one single small trial and wide Cls indicating possibility of benefit or harm in either direction

bDowngraded one level due to high risk of detection bias. 


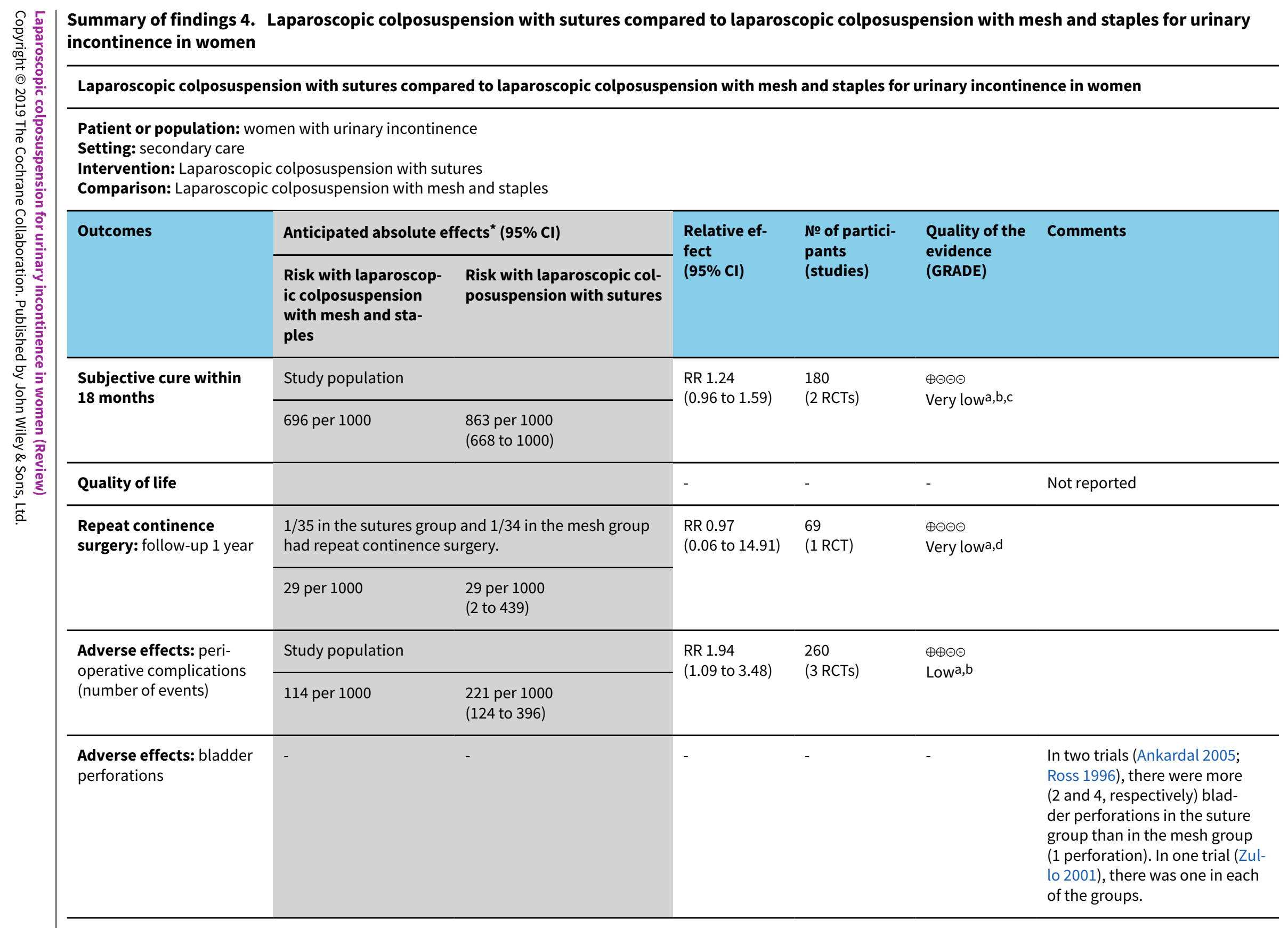




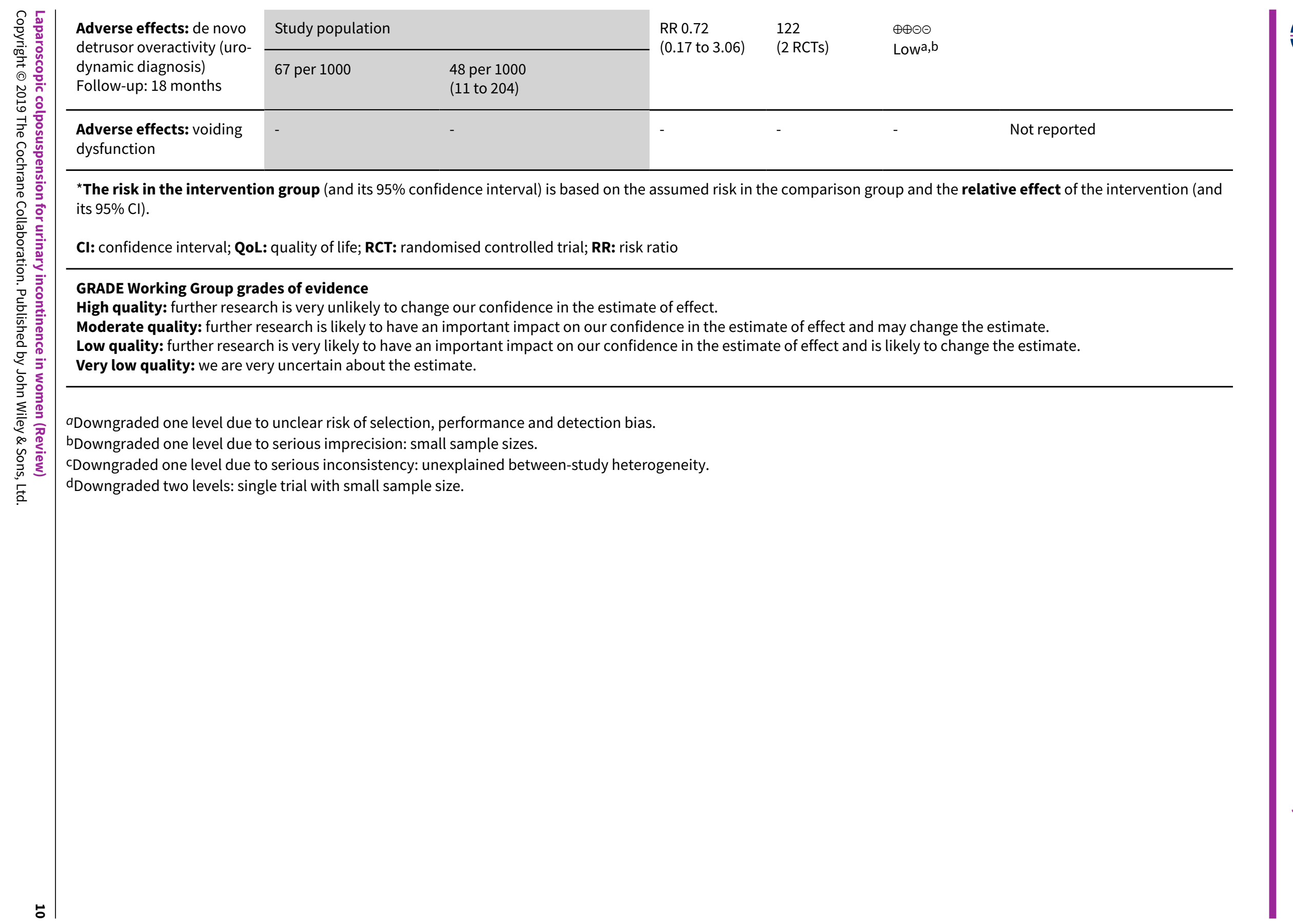




\section{B A C K G R O U N D}

\section{Description of the condition}

Urinary incontinence ( $\mathrm{UI})$ is a common and often debilitating problem for many adult women. It is classified into different types. Stress urinary incontinence (SUI) is defined by the involuntary loss of urine associated with physical exertion and activities that increase intra-abdominal pressure. The International Continence Society and International Urogynaecological Association define urodynamic stress incontinence (USI) as the involuntary leakage of urine during increased abdominal pressure in the absence of a detrusor contraction, noted during filling cystometry (Haylen 2010). Therefore, diagnosis based on this definition requires urodynamic investigation. Urgency urinary incontinence (UUI) is defined as involuntary loss of urine accompanied by or immediately preceded by urgency. Detrusor overactivity (DO) is a diagnosis of involuntary detrusor muscle contractions that are not due to neurological disorders; the diagnosis must be made using urodynamic investigations (Haylen 2010). Mixed urinary incontinence (MUI) is the complaint of involuntary leakage associated both with urgency and with exertion, effort, sneezing or coughing (Abrams 2013). It is thought that urinary incontinence could be due to laxity of the supporting ligament of the pelvis as a result of altered connective tissue (Papa Petros 2010).

Prevalence estimates vary widely (Botlero 2008), but evidence suggests that $25 \%$ to $45 \%$ of adult women are affected by urinary incontinence and that 3\% to $25 \%$ of women have some degree of stress incontinence, with older women more likely to be affected (Abrams 2013). Additionally, a survey published in the British Journal of Obstetrics and Gynaecology demonstrated that up to a third of women of child-bearing age are incontinent during physical exertion or when they cough (Wilson 1996). A longitudinal study of 3763 women showed a prevalence of $37.9 \%$ of persistent urinary incontinence 12 years after birth. Compared with having vaginal delivery, women who delivered exclusively by Caesarean section were less likely to have persistent urinary incontinence. However, this was not the case in women who had a combination of Caesarean section and vaginal birth (MacArthur 2016).

Stress urinary incontinence constitutes a huge financial economic burden to society. In the USA, the annual total direct costs of urinary incontinence in both men and women is over USD 16 billion (1995 USD; Chong 2011), with societal costs of USD 26.2 billion (1995 USD; Wagner 1998). Approximately, USD 13.12 billion (1995 USD) of the total direct costs of urinary incontinence is spent on SUI (Chong 2011; Kunkle 2015). About 70\% of this USD 13.12 billion is borne by people with SUI, mainly through routine care (purchasing pads and disposable underwear (diapers), laundry and dry cleaning). This constitutes a significant individual financial burden. Of the remaining $30 \%$ of costs, $14 \%$ is spent on nursing home admission, $9 \%$ on treatment, $6 \%$ on addressing complications and $1 \%$ on diagnosis (Chong 2011).

A study in the USA reported that approximately $1 \%$ of the median annual household income (USD 50,000 to USD 59,999 in 2006) was spent by women on incontinence management. This study estimated that women spent an annual mean amount of USD 751 to USD 1277 (2006 USD) on incontinence. This cost increases with the severity of the symptoms (Subak 2008). The indirect cost associated with SUI exerts a social and psychological burden that is unquantifiable (Chong 2011; Kilonzo 2004). Nevertheless, Birnbaum 2004 estimated that the annual average direct medical costs of SUI for one year (1998 USD) was USD 5642 and USD 4208 for indirect workplace costs. The cost of management and treatment of SUI appears to have increased over time due to increasing prevalence and an increased desire for improved quality of life. This, in turn, has resulted from improved recognition of the condition, as well as increased use of surgical and non-surgical managements. Guidelines developers usually recommend that surgery for $\mathrm{UI}$ is only considered, by women and their healthcare providers, after other non-invasive or conservative treatments have been tried and failed (NICE 2019).

\section{Description of the intervention}

Surgical procedures to remedy stress urinary incontinence generally aim to lift and support the urethro-vesical junction between the urethra and the bladder and increase bladder outlet resistance. However, there is disagreement regarding the precise mechanism by which continence is achieved after surgery. The choice of procedures is often influenced by co-existent problems, a surgeon's specialty or preference and the physical features of the person affected. Numerous surgical methods have been described but essentially they fall into seven categories:

1. open abdominal retropubic urethropexy (e.g. colposuspension (Burch), Marshall-Marchetti-Krantz; Lapitan 2017);

2. laparoscopic retropubic colposuspension (this review);

3. anterior vaginal repair (anterior colporrhaphy) (e.g. Kelly, Pacey; Glazener 2017a);

4. midurethral/suburethral slings (traditional retropubic tension-free vaginal tape (TVT; Ford 2017), transobturator tape (TOT; Rehman 2017); and single incision slings (Nambiar 2017));

5. needle suspensions (e.g. Pereyra, Stamey; Glazener 2017b);

6. periurethral injections (Kirchin 2017); and

7. artificial sphincters.

\section{How the intervention might work}

Laparoscopic incontinence procedures were first introduced in the early 1990s, with the advantage to patients that they avoided the major incisions of conventional open surgery (Vancaillie 1991). It was claimed that this would result in shorter lengths of hospital stay and shorten the time to return to normal activities.

The most popular laparoscopic procedure for urinary incontinence is laparoscopic colposuspension. As in open colposuspension, sutures are inserted into the vaginal tissues on either side of the neck of the bladder; these are then attached to a ligament on the inside of the pelvic bone called the ileopectineal ligaments on each side respectively. There are, however, technical variations in how the laparoscopic approach is carried out. This would include a variation in the number and type of sutures used and where these are anchored or attached, the use of mesh and staples as an alternative to sutures and whether the laparoscopic approach is carried out transperitoneal (when the laparoscope is inserted into the abdominal cavity) or extraperitoneal (when the laparoscope not inserted into the abdominal cavity) (Abrams 2013; Jarvis 1999).

\section{Why it is important to do this review}

Treatment for stress incontinence includes conservative, pharmacological and surgical therapies. This review is one of a series of inter-related Cochrane Reviews of surgical approaches for the management of urinary incontinence. These include: Ford 2017; Glazen- 
er 2017a; Glazener 2017b; Kang 2015; Kirchin 2017; and Rehman 2017.

In the current context of controversies surrounding the safety of incontinence surgery using mesh, colposuspension has been revived as a preferred treatment option. It is therefore important to revisit the evidence base for this intervention to enable women and clinicians to make informed treatment decisions. In addition, the review also summarises published evidence for both the impacts of the interventions on resource use (costs) and for their comparative efficiency (cost-effectiveness).

\section{O B JECTIVES}

To assess the effects of laparoscopic colposuspension for urinary incontinence in women; and summarise the principal findings of relevant economic evaluations of these interventions.

\section{METHODS}

\section{Criteria for considering studies for this review}

\section{Types of studies}

We included randomised controlled trials (RCTs) or quasi-RCTs of women with stress or mixed urinary incontinence that included laparoscopic colposuspension in at least one arm.

\section{Types of participants}

We included studies of adult women with urinary incontinence who were diagnosed with one or more of the following:

- urodynamic stress incontinence (urodynamic diagnosis)

- stress incontinence (clinical diagnosis)

- mixed incontinence (stress incontinence plus other urinary symptoms such as urgency incontinence)

The definitions we used for the above diagnoses were those used by the authors of the trial reports.

\section{Types of interventions}

At least one arm of a study must have involved laparoscopic colposuspension to treat urinary incontinence.

We made the following nine comparisons.

1. Laparoscopic colposuspension versus no treatment or sham operation

2. Laparoscopic colposuspension versus conservative interventions (e.g. pelvic floor muscle training, electrical stimulation, cones, biofeedback)

3. Laparoscopic colposuspension versus open colposuspension (abdominal surgery)

4. Laparoscopic colposuspension versus traditional sling procedures (abdominal and vaginal surgery)

5. Laparoscopic colposuspension versus midurethral sling procedures (abdominal and vaginal surgery)

6. Laparoscopic colposuspension versus needle suspension (abdominal and vaginal surgery)

7. Laparoscopic colposuspension versus anterior vaginal repair

8. Laparoscopic colposuspension versus periurethral injections

9. One method of laparoscopic colposuspension versus another

\section{Types of outcome measures}

We selected outcome measures used in this review on the basis of their relevance to the clinical cure or improvement of incontinence. As such, we adopted the recommendations made by the Standardisation Committee of the International Continence Society (ICS), which recommends that research looking into the effects of therapeutic interventions for women with urinary incontinence should take into consideration the following outcome domains:

- patient's observations with respect to the symptoms of urinary incontinence

- quantification of patient's symptoms

- clinician's observations (functional and anatomical)

- patient's quality of life

- adverse effects

We have not abstracted urodynamic measurements such as uroflowmetry, post-void residual, leak point pressure and both abdominal and detrusor pressure in this review as they are surrogate measures of bladder function, with uncertain clinical significance.

\section{Primary outcomes}

- Subjective outcome (women's perception of incontinence cure)

* Subjective cure of urinary incontinence within 18 months (short-term)

* Subjective cure of urinary incontinence after 18 months and within five years (medium-term)

* Subjective cure of urinary incontinence after five years (longterm)

\section{Secondary outcomes}

- Women's observations

* Patient-reported use of pads, or number of pads used

* Urgency symptoms (de novo symptoms) or urgency incontinence (clinical diagnosis without urodynamics)

\section{- Quantification of symptoms}

* Number of incontinent episodes (bladder diary)

* Pad tests of quantified leakage (mean volume or weight of urine loss)

- Objective cure (clinicians' measures)

* Stress testing (alone or at cystometrogram)

* Urodynamically-assessed incontinence (the observation of urinary stress incontinence on filling cystometry in the absence of a detrusor contraction)

\section{- Quality of life}

* Condition-specific quality-of-life measures, for example, Urogenital Distress Inventory (Shumaker 1994), or specific instruments designed to assess incontinence

* General health status measures, for example, Short Form 36 (Ware 1993) 
- Surgical outcome measures

* Repeat continence surgery

* Pain or analgesia requirements

* Length of inpatient stay

* Time to return to normal activity level

* Operation time

* Blood loss

* Duration of catheterisation

\section{- Adverse effects}

* Perioperative surgical complications, for example, infection, haemorrhage, bladder perforation (number of events)

* De novo detrusor overactivity (urodynamic diagnosis)

* Voiding dysfunction

* Urinary retention

\section{Main outcomes for 'Summary of findings' tables}

We included the following seven outcomes in 'Summary of findings' tables:

1. Subjective cure; within 18 months

2. Quality of life (condition-specific assessed with standardised questionnaire, such as the Short Incontinence Impact Questionnaire (SIIQ))

3. Repeat continence surgery

4. Adverse effects: perioperative complications (e.g. pain, bleeding); number of events

5. Adverse effects: bladder perforations

6. Adverse effects: de novo detrusor overactivity

7. Adverse effects: voiding dysfunction

\section{Search methods for identification of studies}

We did not impose any language or other limits on the searches.

\section{Electronic searches}

\section{Search for clinical effectiveness studies}

We drew on the search strategy developed for Cochrane Incontinence. We identified relevant trials from the Cochrane Incontinence Specialised Register. For more details of the search methods used to build the Specialised Register, please see the Group's webpages where details of the Register's development (from inception) and the most recent searches performed to populate the Register can be found. To summarise, the Register contains trials identified from the Cochrane Central Register of Controlled Trials (CENTRAL), MEDLINE, MEDLINE In-Process, MEDLINE Epub Ahead of Print, ClinicalTrials.gov, World Health Organization International Clinical Trials Registry Platform (WHO ICTRP), National Institute for Health Research Be Part of Research (NIHR Be Part of Research) and handsearching of journals and conference proceedings. Many of the trials in the Cochrane Incontinence Specialised Register are also contained in CENTRAL.

The date of the last search was 22 May 2019.

The Cochrane Incontinence Specialised Register was searched using the Group's own keyword system. The search terms we used are given in Appendix 1.

\section{Search for economic evaluations}

We also performed supplementary electronic searches designed to identify published reports of relevant economic evaluations to inform the brief economic commentary (BEC) (see 'Incorporating economic evidence' in the Methods). We searched the following databases:

- MEDLINE on OvidSP (covering 1 January 1946 to week 5 July 2018) searched on 10 August 2018;

- Embase on OvidSP (covering 1 January 1980 to week 32 2018) searched on 10 August 2018;

- NHS Economic Evaluation Database (NHS EED) on OvidSP (1st Quarter 2016) searched on 6 April 2017 (this database is no longer updated by the producer).

Appendix 2 contains details of these supplementary electronic searches, including the search terms we used.

\section{Searching other resources}

In addition to the aforementioned searches of bibliographic databases, journals and conference proceedings, we checked all reference lists of identified trials and other relevant articles. We also contacted authors and trialists in the field to identify any additional or unpublished data or trials.

\section{Data collection and analysis}

\section{Selection of studies}

Two review authors independently screened the list of titles and abstracts generated by the search and retrieved full-text articles of potentially relevant trials, which two review authors independently assessed for eligibility. We resolved any differences of opinion through discussion or by involving a third review author.

\section{Data extraction and management}

Two review authors independently extracted data from the included trials using a standardised data extraction form. We resolved any disagreement by discussion or by consulting a third review author. We contacted trial authors where there was insufficient information regarding the outcomes or other relevant aspects of the published reports. We processed data from the included trials according to the Cochrane Handbook for Systematic Reviews of Interventions (Higgins 2011a).

\section{Assessment of risk of bias in included studies}

We assessed the risk of bias in the included trials using the Cochrane 'Risk of bias' tool (Higgins 2017). Two review authors independently assessed the following domains: random sequence generation; allocation concealment; blinding of participants and personnel; blinding of outcome assessment; incomplete outcome data; selective reporting; and other bias. We resolved any differences of opinion through consensus or by consulting a third review author.

\section{Measures of treatment effect}

We based analyses on available data from all included trials relevant to the comparisons and outcomes of interest. For categorical outcomes, we related the numbers reporting an outcome to the numbers at risk in each group to calculate a risk ratio (RR) with $95 \%$ confidence intervals $(\mathrm{CI})$. For continuous variables, we used 
means and standard deviations (SD) to calculate a mean difference (MD) with $95 \% \mathrm{Cl}$. Where data required us to calculate RRs or MDs were not given, we utilised the most detailed numerical data available (e.g. test statistics, $P$ values) to calculate the actual numbers or mean and SDs.

\section{Unit of analysis issues}

The primary analysis was per woman randomised. Where trials had more than two treatment arms, we analysed each pair of arms as a separate comparison. To avoid double-counting participants, where a trial with three treatment arms was included in two subgroups in the same meta-analysis, we divided the number of participants and events by half in the group that was included twice in the meta-analysis.

\section{Dealing with missing data}

We analysed the data on an intention-to-treat basis as far as possible. The principles of intention-to-treat analysis are that outcome data must be measured on all participants, all randomised participants must be included in the analysis and participants must be retained in the intervention groups to which they were assigned (Higgins 2011b). However, for this review the criterion set for intention-to-treat analysis was that participants be retained and analysed in the intervention groups to which they had been assigned. Where this was not the case, we considered whether the trial should be excluded. We made attempts to obtain missing data from the original trialists. However, where this was not possible, we reported data as given in the trials, except where there was evidence of differential loss to follow-up between the intervention groups. In that case, we considered the use of imputation of missing data.

Where mean values were reported without SDs, we assumed the outcome to have a SD equal to the highest SD from the other trials within the same analysis using the Review Manager 5 (RevMan 5) calculator where feasible (Review Manager 2014).

\section{Assessment of heterogeneity}

We only combined trial data if there was no clinical heterogeneity. We investigated differences between trials if significant heterogeneity was found from the $\mathrm{Chi}^{2}$ test or the $\mathrm{I}^{2}$ statistic (Higgins 2003). We followed the guidance in the Cochrane Handbook for Systematic Reviews of Interventions in order to deal with significant heterogeneity according to interpretations of the $\mathrm{I}^{2}$ statistic as follows (Deeks 2017).

- $0 \%$ to $40 \%$ : might not be important

- $30 \%$ to $60 \%$ : may represent moderate heterogeneity

- $50 \%$ to $90 \%$ : may represent substantial heterogeneity

- $75 \%$ to $100 \%$ : considerable heterogeneity

We assessed heterogeneity between studies by visual inspection of plots of the data, the $\mathrm{Chi}^{2}$ test for heterogeneity and the $\mathrm{I}^{2}$ statistic (Higgins 2003). We deemed visual heterogeneity positive when the confidence intervals of studies did not overlap. This was then confirmed by formal statistical testing.

\section{Assessment of reporting biases}

Had data allowed, we planned to assess the likelihood of potential publication bias using funnel plots, provided that 10 or more eligible trials were identified.

\section{Data synthesis}

We combined trials with similar interventions in a meta-analysis using a fixed-effect model unless there was evidence of heterogeneity across studies. Where significant heterogeneity existed, we used a random-effects model.

\section{Subgroup analysis and investigation of heterogeneity}

We performed subgroup analyses comparing the variations in surgical techniques within similar surgical procedure subgroups, e.g. laparoscopic colposuspension using sutures or laparoscopic colposuspension using mesh compared with open colposuspension. This latter subgroup analysis was conducted to reflect the recent clinical trend favouring using sutures with laparoscopic colposuspension rather than mesh.

\section{Sensitivity analysis}

Had data allowed, we had planned sensitivity analyses comparing trials with low risk of selection bias to those with high risk of selection bias.

\section{'Summary of findings' tables}

We used the GRADE system to assess the quality of the body of evidence (Guyatt 2008). This approach uses four categories (very low, low, moderate and high) to rate the quality of evidence available for selected outcomes. As an example, evidence from RCTs starts at a level of high quality but may be downgraded if there are other indications of low quality, such as small sample sizes or high risk of bias. Where we applied such downgrading, we have noted it in footnotes in the 'Summary of findings' tables.

\section{Incorporating economic evidence}

Following the search outlined in the Search methods for identification of studies, we developed a brief economic commentary (BEC) to summarise the availability and principal findings of the full economic evaluations that compare laparoscopic colposuspension versus other procedures for treating urinary incontinence in women (Shemilt 2019). This BEC encompasses full economic evaluations (i.e. cost-effectiveness analyses, cost-utility-analyses and cost-benefit analyses), conducted alongside or based upon one or more RCTs included in the main review of intervention effects (primarily trial-based economic evaluations), or using a modelling framework (primarily model-based economic evaluations). This commentary focuses on the extent to which principal findings of eligible economic evaluations indicate that an intervention might be judged favourably or unfavourably from an economic perspective when implemented in different settings.

\section{RE S U L T S}

\section{Description of studies}

\section{Results of the search}

\section{Search for clinical effectiveness studies}

We screened a total of 96 records produced by the literature search and identified 61 reports of 26 included studies. The flow of literature through the assessment process is shown in Figure 1. Seven trials were reported only as abstracts (Adile 2001; Burton 1997; Maher 2004; Mirosh 2005; Morris 2001; Stangel-Wojcikiewicz 2008; Summitt 2000). Where we required more detailed trial information we contacted the trial authors. 
Figure 1. PRISMA study flow diagram: search for effectiveness studies

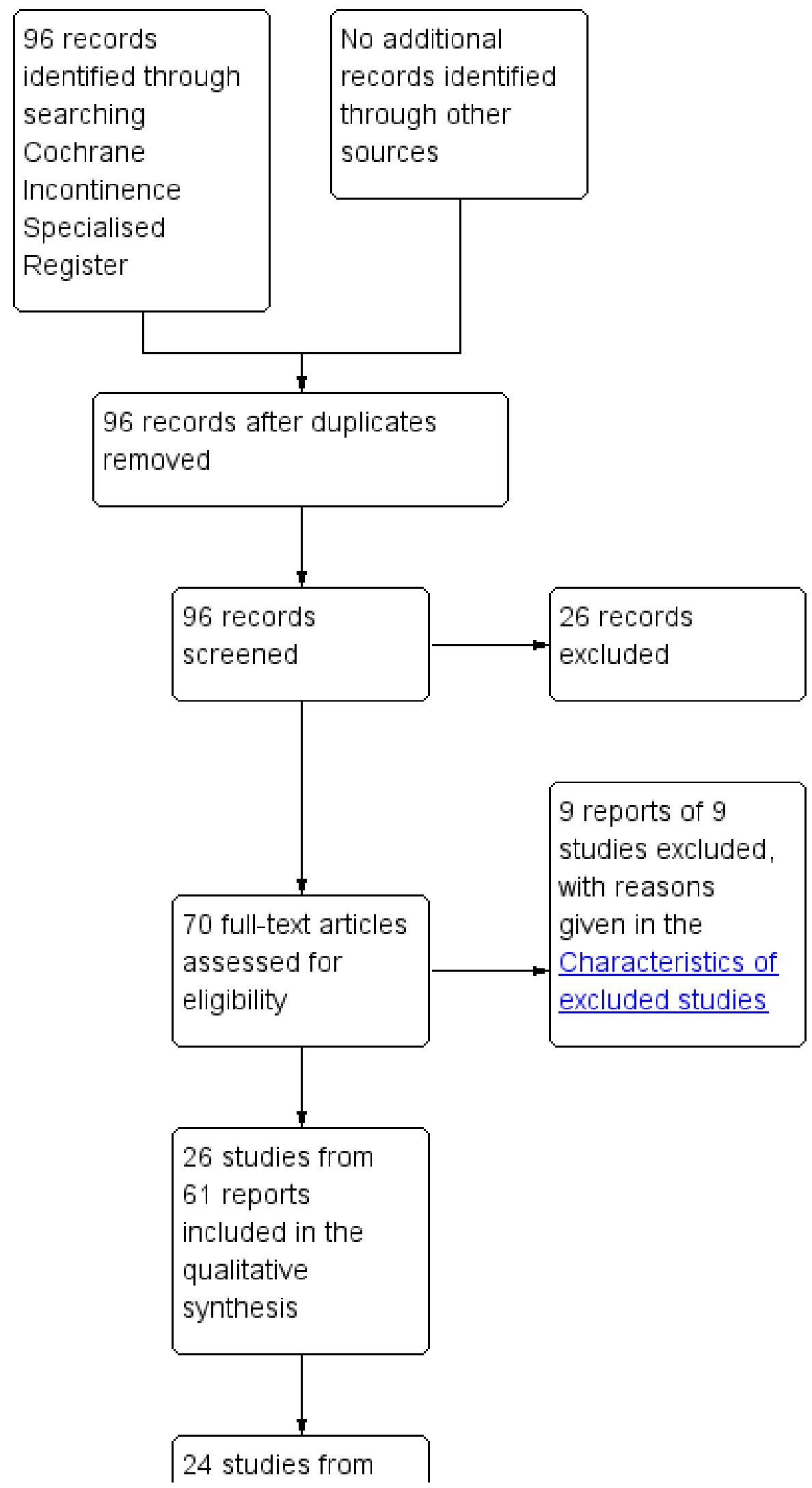


Figure 1. (Continued)

24 studies from
59 reports
included in the
quantitative
synthesis
(meta-analysis)


In total, we included 26 trials in this review (Adile 2001; Ankardal 2004; Ankardal 2005; Burton 1997; Carey 2006; Cheon 2003; Fatthy 2001; Foote 2006; Kitchener 2006; Maher 2004; Mirosh 2005; Morris 2001; Paraiso 2004; Persson 2000; Persson 2002; Ross 1996; Samiee 2009; Stangel-Wojcikiewicz 2008; Su 1997; Summitt 2000; Tuygun 2006; Ustun 2003; Ustun 2005; Valpas 2004; Wallwiener 1995; Zullo 2001).

Figure 2. PRISMA study flow diagram: search for economic evaluations for the BEC

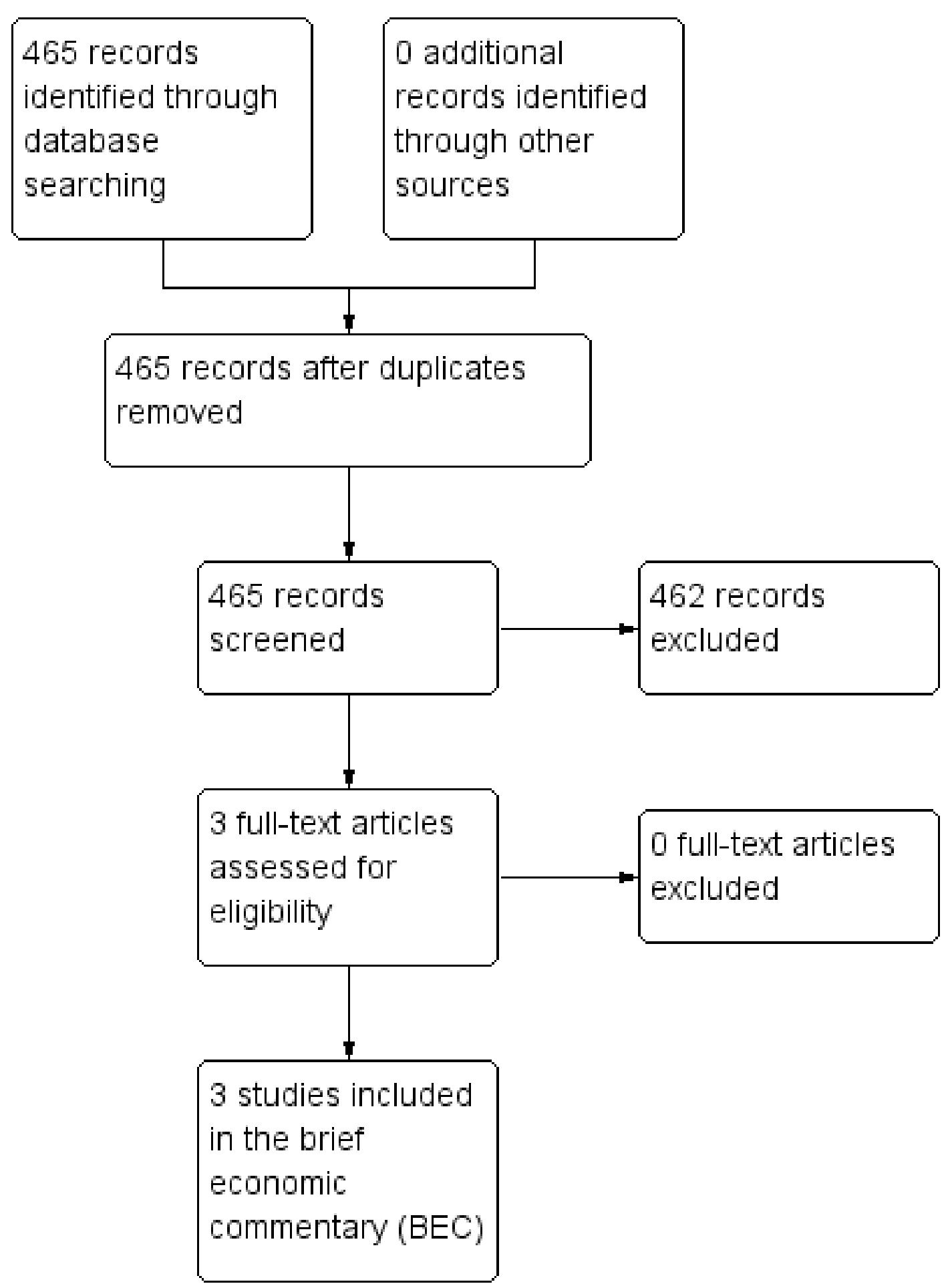

\section{Search for economic evaluations}

Searches for economic evaluations to inform the development of the brief economic commentary (BEC) produced a total of 465 titles and abstracts to be screened, from which three met the inclusion criteria (Cody 2003; Dumville 2006; Valpas 2006). The flow of literature through the assessment process is shown in Figure 2. 


\section{Included studies}

Of the 26 included trials, thirteen (1396 women) involved the comparison of laparoscopic with open colposuspension (Ankardal 2004; Ankardal 2005; Burton 1997; Carey 2006; Cheon 2003; Fatthy 2001; Kitchener 2006; Morris 2001; Stangel-Wojcikiewicz 2008; Su 1997; Summitt 2000; Tuygun 2006; Ustun 2005). Nine (412 women) compared laparoscopic colposuspension with midurethral vaginal tapes; seven with retropubic TVT, one with SPARC and one with TOT approach (Adile 2001; Foote 2006; Maher 2004; Mirosh 2005; Paraiso 2004; Persson 2002; Samiee 2009; Ustun 2003; Valpas 2004). Five trials compared the variation in the surgical techniques and methods of laparoscopic colposuspension (444 women; Ankardal 2005; Persson 2000; Ross 1996; Wallwiener 1995; Zullo 2001).

Detailed information about the included trials can be found in the Characteristics of included studies.

\section{Design}

The included trials were RCTs or quasi-RCTs of surgery for urinary incontinence, with laparoscopic colposuspension in at least one arm.

\section{Sample sizes}

Sample sizes ranged from 20 to 300 , with 18 trials (68\%) having fewer than 50 women in each arm.

\section{Participants}

The 26 included trials randomised a total of 2271 women. Judged on the trial reports, all participants had had prior urodynamic investigation, although this was only clearly stated in 22 trials (Ankardal 2004; Ankardal 2005; Burton 1997; Carey 2006; Cheon 2003; Fatthy 2001; Foote 2006; Kitchener 2006; Maher 2004; Mirosh 2005; Paraiso 2004; Persson 2000; Persson 2002; Ross 1996; Su 1997; Samiee 2009; Stangel-Wojcikiewicz 2008; Summitt 2000; Ustun 2003; Ustun 2005; Valpas 2004; Zullo 2001). Thus, all trials appeared to have been undertaken on women with urodynamic stress incontinence.

All but three of the included trials stated their exclusion criteria (Morris 2001; Tuygun 2006; Ustun 2003). Seventeen trials excluded women with previous continence surgery; eight did not (Carey 2006; Fatthy 2001; Foote 2006; Kitchener 2006; Maher 2004; Stangel-Wojcikiewicz 2008; Tuygun 2006; Wallwiener 1995). For one of these trials, recurrent urinary stress incontinence was an inclusion criteria (Maher 2004). Twelve trials excluded women who had had previous retropubic surgery (Adile 2001; Ankardal 2004; Ankardal 2005; Burton 1997; Carey 2006; Foote 2006; Kitchener 2006; Mirosh 2005; Persson 2000; Samiee 2009; Summitt 2000; Zullo 2001).

Twelve trials excluded women with detrusor overactivity (Fatthy 2001; Foote 2006; Kitchener 2006; Mirosh 2005; Paraiso 2004; Ross 1996; Su 1997; Samiee 2009; Stangel-Wojcikiewicz 2008; Summitt 2000; Ustun 2005; Valpas 2004), while one trial excluded women with urgency incontinence but included women with urgency symptoms (Persson 2000).

Twelve trials excluded women with varying degrees of pelvic organ prolapse (Fatthy 2001; Foote 2006; Maher 2004; Mirosh 2005; Paraiso 2004; Persson 2000; Persson 2002; Samiee 2009; Stangel-Wojcikiewicz 2008; Su 1997; Wallwiener 1995; Zullo 2001).
Eight trials excluded women who required concomitant gynaecological operations, making the trial intervention a sole procedure (Adile 2001; Ankardal 2004; Ankardal 2005; Foote 2006; Mirosh 2005; Persson 2002; Summitt 2000; Valpas 2004).

\section{Duration of follow-up}

All trials reported follow-up outcomes within 18 months (shortterm), with the exception of one (Morris 2001). Five trials had a follow-up time longer than 18 months and within five years (medium-term; Adile 2001; Burton 1997; Kitchener 2006; Paraiso 2004; Tuygun 2006), while three trials reported on follow-up after five years (long-term; Burton 1997; Morris 2001; Paraiso 2004).

\section{Interventions and comparators}

\section{Method of laparoscopic approach}

Of the included 26 trials, 16 stated the method of approach used for the laparoscopic colposuspension. Ten trials used the transperitoneal approach (Ankardal 2004; Burton 1997; Carey 2006; Cheon 2003; Foote 2006; Persson 2000; Ross 1996; Summitt 2000; Ustun 2005; Zullo 2001), while five trials used the extraperitoneal approach (Fatthy 2001; Paraiso 2004; Samiee 2009; Tuygun 2006; Valpas 2004). One compared a transperitoneal with an extraperitoneal approach (Wallwiener 1995).

\section{Laparoscopic compared with open colposuspension}

Twelve trials compared laparoscopic colposuspension with open colposuspension but they were not consistent in either the number or type of mesh or sutures used (Ankardal 2004; Ankardal 2005; Burton 1997; Carey 2006; Cheon 2003; Fatthy 2001; Kitchener 2006; Morris 2001; Stangel-Wojcikiewicz 2008; Summitt 2000; Tuygun 2006; Ustun 2005). Burton 1997 used absorbable Dexon sutures and Tuygun 2006 used polyglactin sutures, whereas seven trials used either non-absorbable sutures (mainly Ethibond; Ankardal 2004; Ankardal 2005; Carey 2006; Cheon 2003; Kitchener 2006; Su 1997; Summitt 2000), or polypropylene sutures (Fatthy 2001). With the exception of Ankardal 2004, all trials used the same number and type of suspension material for both the laparoscopic and open procedures. Ankardal 2004 used a polypropylene mesh and titanium staples for the laparoscopic colposuspensions and sutures for the open colposuspensions.

\section{Laparoscopic colposuspension compared with midurethral sling} procedures

Nine trials compared laparoscopic colposuspension with self-fixing vaginal mesh slings (Adile 2001; Foote 2006; Maher 2004; Mirosh 2005; Paraiso 2004; Persson 2002; Samiee 2009; Ustun 2003; Valpas 2004). Seven of these studies used a TVT for the vaginal sling technique and one study used SPARC (Foote 2006), which is a midurethral sling similar to TVT but is inserted from above downwards rather than from below upwards. One study compared TOT with laparoscopic colposuspension using silk sutures (Samiee 2009), and one study used tacker mesh for the laparoscopic colposuspension (Valpas 2004), whereas four trials reported using two single-bite non-absorbable sutures each side (Foote 2006; Paraiso 2004; Persson 2002; Ustun 2003). The main differences between the interventions in this group was the type of anaesthesia used. In all trials, the laparoscopic colposuspensions were performed under a general anaesthetic. Further details about the anaesthesia were reported in six trials, with two reporting that the self-fixing sling operations were performed under local anaesthetic with sedation 
(Persson 2002; Valpas 2004), under regional anaesthesia (spinal or epidural) in two trials (Adile 2001; Mirosh 2005), and a combination of general, regional and local with sedation in two other trials (Paraiso 2004; Ustun 2003).

\section{One method of laparoscopic colposuspension versus another}

Five trials compared different operative techniques or approaches for laparoscopic colposuspension (Ankardal 2005; Persson 2000; Ross 1996; Wallwiener 1995; Zullo 2001). Of these, three trials compared polypropylene mesh fixed with staples or tacks with Ethibond or Gore-Tex sutures (Ankardal 2005; Ross 1996; Zullo 2001). Persson 2000 compared two single-bite Gore-Tex sutures with one double-bite suture on each side of the urethra. Wallwiener 1995 compared extraperitoneal with transperitoneal access using GoreTex sutures or mesh and staples.

\section{Outcome measures}

Fourteen trials reported subjective cure as a measure of operative success (Ankardal 2004; Ankardal 2005; Carey 2006; Cheon 2003; Fatthy 2001; Foote 2006; Kitchener 2006; Maher 2004; Morris 2001; Persson 2000; Persson 2002; Ustun 2003; Valpas 2004; Zullo 2001), although they used different instruments and scales to assess cure:

- urine leakage reported by women;

- use of pads; and

- questionnaires completed by women.

Thirteen trials used objective measures in the form of a pad test or reported incontinence episodes (Ankardal 2004; Ankardal 2005; Burton 1997; Cheon 2003; Fatthy 2001; Foote 2006; Kitchener 2006; Morris 2001; Paraiso 2004; Persson 2000; Persson 2002; Su 1997; Valpas 2004). Eleven trials used urodynamic measurements preand postoperatively but put their emphasis on different parameters, not all using the measurements as their definition of cure (Burton 1997; Carey 2006; Cheon 2003; Fatthy 2001; Maher 2004; Paraiso 2004; Ross 1996; Su 1997; Summitt 2000; Ustun 2003; Zullo 2001).

Ten trials assessed leakage observed by a health professional on a clinical stress test, which reported the data as objective cure rates. Six trials used negative urodynamic testing as their definition of cure (Burton 1997; Carey 2006; Cheon 2003; Fatthy 2001; Stangel-Wojcikiewicz 2008; Summitt 2000), while four trials used a negative pad test as their definition of objective cure (Ankardal 2004; Ankardal 2005; Kitchener 2006; Morris 2001).
Ten trials assessed quality of life as an outcome (Ankardal 2004; Ankardal 2005; Carey 2006; Cheon 2003; Foote 2006; Kitchener 2006; Maher 2004; Mirosh 2005; Paraiso 2004; Valpas 2004). However, all the trials used various assessment questionnaires (e.g. Short Form 36 (SF-36), King's Health Questionnaire (KHQ), Incontinence Impact Questionnaire (IIQ), Urogenital Distress Inventory (UDI)) and in differing combinations. Two trials that assessed quality of life did not report which validated questionnaire they used and did not report the results (Cheon 2003; Mirosh 2005).

All except three trials reported the number of perioperative complications and types of complications. One of these reported no major complications (Wallwiener 1995); the other two reported that the number of complications were similar in each arm (Maher 2004; Morris 2001).

Morris 2001 only reported on de novo detrusor overactivity after five years, which was similar in each arm. Maher 2004 reported de novo detrusor overactivity and voiding dysfunction. Both of these outcomes were found to be similar in each arm.

\section{Excluded studies}

We excluded nine trials from the review (ISRCTN44339585; Choi 2006; Foote 2007; Koster 1996; Lee 1997; Lernis 1997; NCT00573703; Prezioso 2013; Salam 2004). Four were either not RCTs or did not mention a randomisation process (Choi 2006; Lee 1997; Lernis 1997; Salam 2004). One prospective study had no comparator group (Prezioso 2013). One study was withdrawn as it did not start (NCT00573703). Another study did not assess laparoscopy for incontinence (Koster 1996). Personal correspondence with one trial author confirmed that one study did not start recruitment (ISRCTN44339585). In another study, randomisation broke down when one recruitment source only referred women for the laparoscopic procedure, leading to the trial continuing as a cohort study (Foote 2007).

More details can be found in the Characteristics of excluded studies.

\section{Risk of bias in included studies}

Figure 3 and Figure 4 summarise the 'Risk of bias' assessment for the included trials. 
Figure 3. 'Risk of bias' graph: review authors' judgements about each 'Risk of bias' item presented as percentages across all included studies

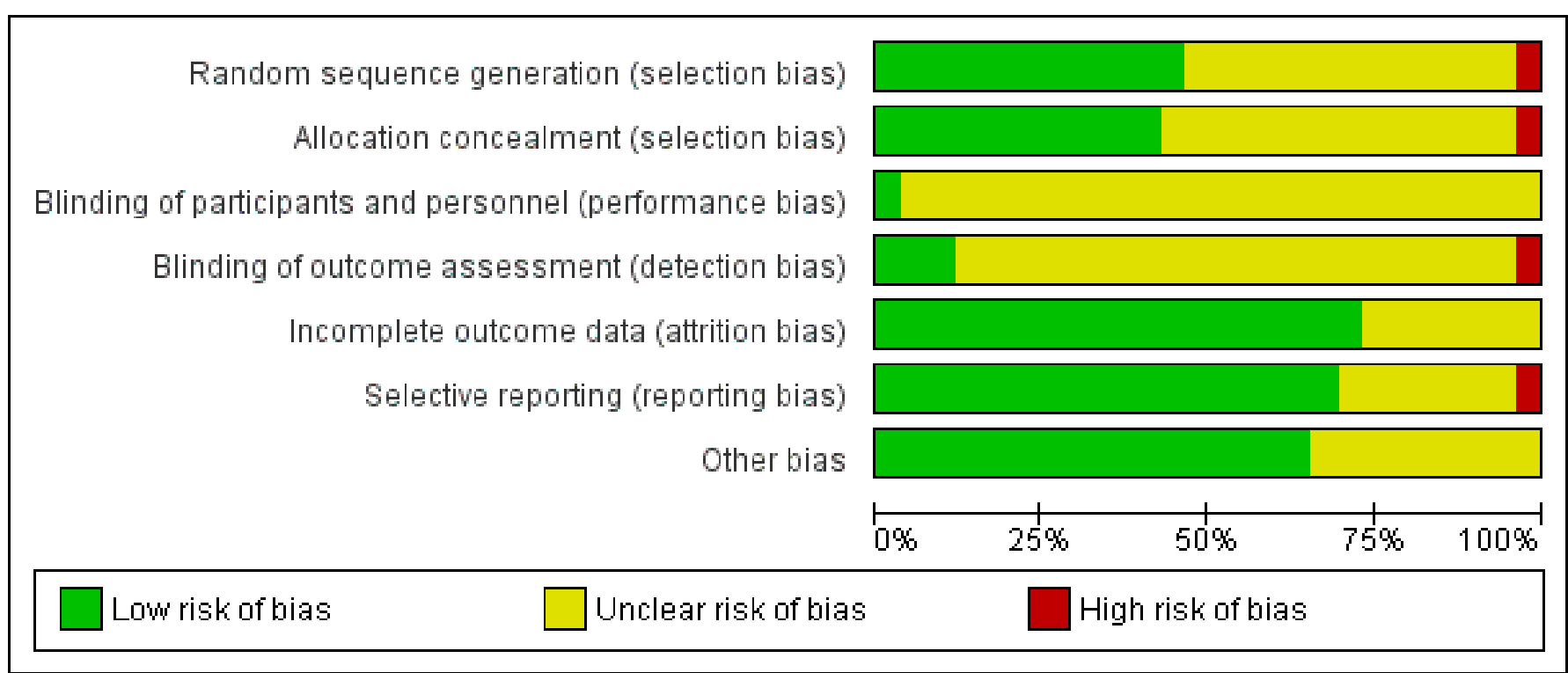


Figure 4. 'Risk of bias' summary: review authors' judgements about each 'Risk of bias' item for each included study

\begin{tabular}{|c|c|c|c|c|c|c|c|}
\hline & 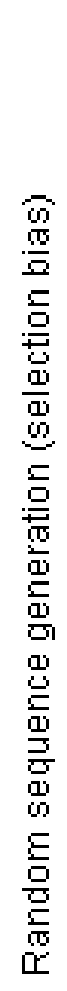 & 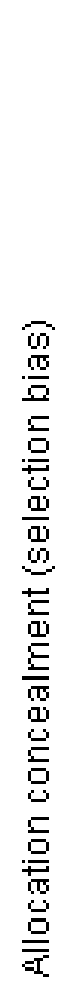 & 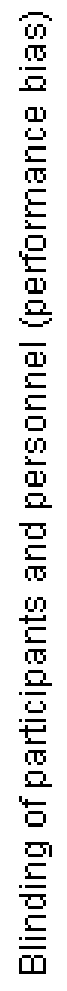 & 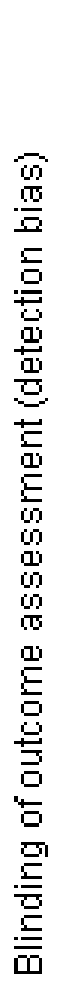 & 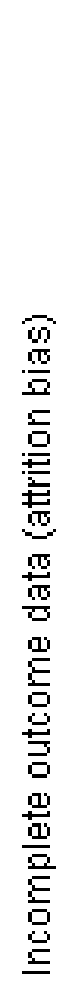 & 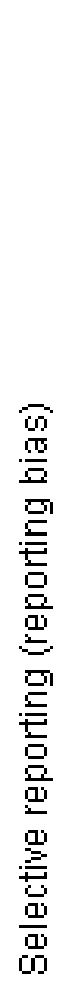 & 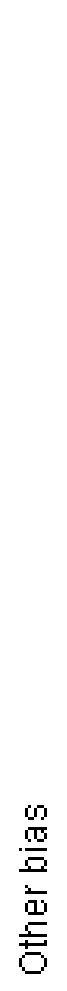 \\
\hline Adile 2001 & $?$ & $?$ & $?$ & $?$ & $?$ & $?$ & $?$ \\
\hline Ankardal 2004 & $?$ & + & $?$ & $?$ & + & + & + \\
\hline Ankardal 2005 & $?$ & + & $?$ & $?$ & + & + & + \\
\hline Burton 1997 & $?$ & $?$ & $?$ & $?$ & $?$ & + & $?$ \\
\hline Carey 2006 & + & + & + & $?$ & + & + & + \\
\hline Cheon 2003 & + & + & $?$ & $?$ & + & + & + \\
\hline Fatthy 2001 & $\Omega$ & + & $?$ & $?$ & C & + & + \\
\hline Foote 2006 & $\Omega$ & $?$ & $?$ & $?$ & + & + & + \\
\hline Kitchener 2006 & + & $?$ & $?$ & $?$ & + & + & + \\
\hline Maher 2004 & 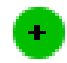 & $?$ & $?$ & $?$ & 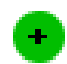 & + & $?$ \\
\hline Mirosh 2005 & $?$ & $?$ & $?$ & $?$ & 1 & $?$ & $?$ \\
\hline Morris 2001 & ? & $?$ & $?$ & $?$ & + & $?$ & $?$ \\
\hline$\ldots$ & 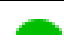 & 1 & 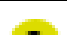 & ? & ค & 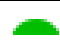 & \\
\hline
\end{tabular}


Figure 4. (Continued)

\begin{tabular}{|c|c|c|c|c|c|c|c|}
\hline Morris 2001 & $?$ & $?$ & $?$ & $?$ & + & $?$ & $?$ \\
\hline Paraiso 2004 & + & + & $?$ & + & + & + & + \\
\hline Persson 2000 & + & + & $?$ & 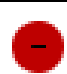 & $?$ & + & $?$ \\
\hline Persson 2002 & + & + & $?$ & + & + & + & + \\
\hline Ross 1996 & $?$ & + & $?$ & $?$ & + & + & + \\
\hline Samiee 2009 & $?$ & $?$ & $?$ & $?$ & $?$ & ? & + \\
\hline Stangel-Wojcikiewicz 2008 & $?$ & ? & ? & ? & + & ? & ? \\
\hline Su 1997 & . & & $?$ & $?$ & + & + & + \\
\hline Summitt 2000 & $?$ & $?$ & $?$ & $?$ & $?$ & $?$ & $?$ \\
\hline Tuygun 2006 & $?$ & ? & $?$ & ? & $?$ & + & + \\
\hline Ustun 2003 & $?$ & ? & $?$ & $?$ & + & & ( \\
\hline Ustun 2005 & + & + & $?$ & $?$ & + & + & + \\
\hline Valpas 2004 & $\oplus$ & + & $?$ & $?$ & 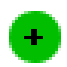 & + & $?$ \\
\hline Wallwiener 1995 & $?$ & ? & ? & ? & ? & ? & + \\
\hline Zullo 2001 & + & ? & $?$ & + & + & + & + \\
\hline
\end{tabular}




\section{Allocation}

\section{Random sequence generation}

We judged 12 trials to be at low risk for sequence generation (Carey 2006; Cheon 2003; Fatthy 2001; Foote 2006; Kitchener 2006; Maher 2004; Paraiso 2004; Persson 2000; Persson 2002; Ustun 2005; Valpas 2004; Zullo 2001). We judged one trial to be high risk in this domain because of deviations from the randomisation and allocation procedure for participants who were not willing to undergo laparoscopic colposuspension (the trial authors did not report the number of participants for which this was the case; Su 1997). The remaining 13 trials did not report their methods in sufficient detail to judge whether allocation to groups was fully randomised and therefore were at unclear risk of bias (Adile 2001; Ankardal 2004; Ankardal 2005; Burton 1997; Mirosh 2005; Morris 2001; Ross 1996; Samiee 2009; Stangel-Wojcikiewicz 2008; Summitt 2000; Tuygun 2006; Ustun 2003; Wallwiener 1995).

\section{Allocation concealment}

We judged 12 trials to be at low risk for allocation concealment (Ankardal 2004; Ankardal 2005; Burton 1997; Carey 2006; Cheon 2003; Fatthy 2001; Paraiso 2004; Persson 2002; Persson 2000; Ross 1996; Ustun 2005; Valpas 2004). We judged one trial to be high risk in this domain because of deviations from the randomisation and allocation procedure for participants who were not willing to undergo laparoscopic colposuspension (the trial authors did not report the number of participants for which this was the case; Su 1997). The remaining 13 trials did not provide sufficient information to permit judgement and therefore we classified them as unclear (Adile 2001; Foote 2006; Kitchener 2006; Maher 2004; Mirosh 2005; Morris 2001; Samiee 2009; Stangel-Wojcikiewicz 2008; Summitt 2000; Tuygun 2006; Ustun 2003; Wallwiener 1995; Zullo 2001).

\section{Blinding}

\section{Blinding of participants and care givers (performance bias}

We judged only one trial to be at low risk of performance bias in terms of blinding (Carey 2006). In this trial, participants and assessors were blinded in that the abdominal wounds were dressed in theatre in an identical fashion. As such, both participants and ward staff were masked to the procedure performed until the removal of dressings prior to discharge. For the remainder of the trials, we judged the risk of performance bias to be unclear on the grounds that blinding of participants and care givers is generally not possible in the context of surgical trials; it is not clear the extent to which knowledge of the intervention allocated could have an impact on outcomes.

Furthermore, it was unclear the degree to which performance bias may have been present due to the surgical learning curve. The surgeons in three trials had performed fewer than 20 laparoscopic colposuspensions before starting the trial (Burton 1997; Cheon 2003; Fatthy 2001). Other trials either reported surgeons as being senior gynaecologists with extensive experience in both procedures (Ankardal 2004; Ankardal 2005; Carey 2006; Kitchener 2006), or did not report the experience of the surgeons (Morris 2001; Summitt 2000).

\section{Blinding of outcome assessors (detection bias)}

We judged one trial to be at high risk of detection bias because the same physician who operated on the participants also performed the follow-up evaluations and interviews without being blinded (Persson 2000). Three trials employed adequate methods of blinding of outcome assessors and we therefore judged them to be at low risk of detection bias (Paraiso 2004; Persson 2002; Zullo 2001). We judged the remaining trials to be unclear in terms of risk of detection bias because they did not report sufficient detail with regard to blinding of outcome assessors.

\section{Incomplete outcome data}

Nineteen trials reported sufficient information regarding attrition to be judged at low risk of attrition bias; generally they reported no differential attrition, provided adequate explanations for losses to follow-up and/or carried out intention-to-treat analysis (Ankardal 2004; Ankardal 2005; Carey 2006; Cheon 2003; Fatthy 2001; Foote 2006; Kitchener 2006; Maher 2004; Mirosh 2005; Morris 2001; Paraiso 2004; Persson 2002; Ross 1996; Stangel-Wojcikiewicz 2008; Su 1997; Ustun 2003; Ustun 2005; Valpas 2004; Zullo 2001).

We judged the following seven trials to be unclear due to insufficient information (Adile 2001; Burton 1997; Persson 2000; Samiee 2009; Summitt 2000; Tuygun 2006; Wallwiener 1995).

\section{Selective reporting}

We judged 18 trials to be at low risk of reporting bias (Ankardal 2004; Ankardal 2005; Burton 1997; Carey 2006; Cheon 2003; Fatthy 2001; Foote 2006; Kitchener 2006; Maher 2004; Paraiso 2004; Persson 2000; Persson 2002; Ross 1996; Su 1997; Tuygun 2006; Ustun 2005; Valpas 2004; Zullo 2001). We judged one trial to be at high risk (Ustun 2003), while we judged seven trials to be unclear (Adile 2001; Mirosh 2005; Morris 2001; Samiee 2009; Stangel-Wojcikiewicz 2008; Summitt 2000; Wallwiener 1995).

\section{Other potential sources of bias}

Persson 2000 set out to enrol 280 participants but the trial authors became convinced during follow-up that one trial arm had a higher cure rate. For ethical reasons, they therefore performed an interim analysis on the objective one-year cure rate on 108 participants, which confirmed a higher cure rate in one group. Thereafter, further enrolment was stopped and only the 161 participants who had already been recruited were followed up; the analysis was adjusted for the early stopping. We judged this trial to be at unclear risk of bias, as the early stoppage may have had an impact on the overall result.

In one trial, the number of women recruited fell short of the target, owing to limitations of time and recruiting problems (Valpas 2004). As a result, this study was also stopped prematurely. However, the trial authors still considered the groups to be comparable and they analysed data without adjustment after stopping the study. We judged this trial to be at unclear risk of bias, as it was not clear if this could have had an impact on the overall result.

We judged seven other trials that were published as conference abstracts to be unclear regarding other potential sources of bias (Adile 2001; Burton 1997; Maher 2004; Mirosh 2005; Morris 2001; Stangel-Wojcikiewicz 2008; Summitt 2000). We judged the remaining 17 trials to be at low risk of bias (Ankardal 2004; Ankardal 2005; Carey 2006; Cheon 2003; Fatthy 2001; Foote 2006; Kitchener 2006; Paraiso 2004; Persson 2002; Ross 1996; Samiee 2009; Su 1997; Tuygun 2006; Ustun 2003; Ustun 2005; Wallwiener 1995; Zullo 2001). 


\section{Effects of interventions}

See: Summary of findings for the main comparison Laparoscopic colposuspension compared to open colposuspension for urinary incontinence in women; Summary of findings 2 Laparoscopic colposuspension compared to midurethral sling procedures for urinary incontinence in women; Summary of findings 3 Laparoscopic colposuspension with one suture compared to laparoscopic colposuspension with two sutures for urinary incontinence in women; Summary of findings 4 Laparoscopic colposuspension with sutures compared to laparoscopic colposuspension with mesh and staples for urinary incontinence in women

\section{Laparoscopic colposuspension versus no treatment or sham operation}

We did not find any eligible trials.

\section{Laparoscopic colposuspension versus conservative interventions (e.g. pelvic floor muscle training, electrical stimulation, cones, biofeedback)}

We did not find any eligible trials.

\section{Laparoscopic colposuspension versus open colposuspension}

Thirteen trials compared laparoscopic with open colposuspension (Ankardal 2004; Ankardal 2005; Burton 1997; Carey 2006; Cheon 2003; Fatthy 2001; Kitchener 2006; Morris 2001; Summitt 2000; Stangel-Wojcikiewicz 2008; Su 1997; Tuygun 2006; Ustun 2005). We later subgrouped these into those trials that utilised sutures to carry out the colposuspension and those trials that used mesh and staples. This addressed the statistically significant heterogeneity reflected in some of the results when combining different methods of carrying out the colposuspension.

All the trials had different lengths of follow-up: one trial for six months (Carey 2006); five trials for one year (Ankardal 2004; Ankardal 2005; Cheon 2003; Su 1997; Summitt 2000); one trial for 6 and 18 months (Fatthy 2001); one trial for 6, 12 and 24 months (Kitchener 2006); one trial for six months, one year, three years and five years (Burton 1997); one trial from 18 months to five years (Tuygun 2006); and two trials for 18 months (Stangel-Wojcikiewicz 2008; Ustun 2005).

Outcome data for six to 18 months' follow-up were therefore available for 10 trials. Longer-term data, over five years, were only available for two trials (Burton 1997; Morris 2001). Morris 2001 had only five- to seven-year follow-up data, with no earlier follow-up results reported. The ability to synthesise data was also limited by the variable tests and definitions used to measure subjective and objective outcomes across the trials and failure to report standard deviations.

\section{Primary outcomes}

\section{Subjective cure of urinary incontinence within 18 months}

The pooled RR for subjective cure of urinary incontinence within 18 months after laparoscopic colposuspension relative to open colposuspension was $0.92(95 \% \mathrm{Cl} 0.81$ to $1.05 ; 1117$ women; Ankardal 2004; Ankardal 2005; Carey 2006; Cheon 2003; Fatthy 2001; Kitchener 2006; Tuygun 2006; Ustun 2005; Analysis 1.1). The test for subgroup differences indicated heterogeneity between subgroups $(\mathrm{P}<$ 0.00001 ). The $95 \% \mathrm{Cls}$ of the two summary estimates do not overlap, which suggests that using sutures or mesh and staples has dif- ferent effects. Within 18 months, there is little difference between laparoscopic colposuspension using sutures and open colposuspension in terms of subjective cure (RR 1.04, 95\% Cl 0.99 to $1.08,755$ women; Ankardal 2005; Carey 2006; Cheon 2003; Fatthy 2001; Kitchener 2006; Ustun 2005; high-quality evidence; Analysis 1.1; Summary of findings for the main comparison). We are uncertain whether there is any difference in subjective cure between laparoscopic colposuspension (using mesh and staples) and open colposuspension (RR 0.75, 95\% Cl 0.61 to 0.93, 362 women; Ankardal 2004; Ankardal 2005; Tuygun 2006; very low-quality evidence; Analysis 1.1; Summary of findings for the main comparison).

\section{Subjective cure of urinary incontinence after 18 months and within five years}

Two trials reported subjective cure at between 18 months and five years' follow-up (Kitchener 2006; Tuygun 2006). There appears to be little difference between laparoscopic colposuspension and open colposuspension (RR $0.94,95 \% \mathrm{Cl} 0.77$ to 1.14 ; 323 women; Analysis 1.2).

The test for subgroup differences regarding laparoscopic colposuspension with sutures and laparoscopic colposuspension with mesh and staples did not identify evidence of heterogeneity $(P=0.16)$ and the $95 \% \mathrm{Cls}$ of the two summary estimates overlapped closely. Therefore, there was no evidence that the effects may be different in these two subgroups.

\section{Subjective cure of urinary incontinence after five years}

At five years' follow-up, one trial found no evidence of a difference in subjective cure rates between women undergoing laparoscopic colposuspension and those undergoing open colposuspension (RR $1.53,95 \% \mathrm{Cl} 1.00$ to 2.35; 64 women; Morris 2001). One trial measured subjective cure on a 1 to 10 visual analogue scale (VAS), where a higher score equals a better outcome (Burton 1997). At five-year follow-up, the mean score in the laparoscopic group was 9.4, compared to 4.4 in the open group.

\section{Secondary outcomes}

Women's observations

None of the included studies reported this outcome.

\section{Quantification of symptoms}

Two trials used different methods to quantify symptoms. There appeared to be little difference between the groups in incontinence episodes per 24 hours at 18 months' follow-up in one trial (MD - 0.12 episodes, $95 \% \mathrm{Cl}-0.68$ to $0.92 ; 73$ women; Fatthy 2001 ). Another trial reported more incontinence episodes per 24 hours in the laparoscopic group than in the open group at 18 months' follow-up but reported data without standard deviations ( 6 versus 2, 30 women in each group; Burton 1997).

\section{Objective cure (clinicians' measures)}

There appears to be little or no difference between laparoscopic and open colposuspension in terms of objective cure within 18 months (RR 0.94, 95\% Cl 0.86 to 1.02; 1117 women; Ankardal 2004; Ankardal 2005; Burton 1997; Carey 2006; Cheon 2003; Fatthy 2001; Kitchener 2006; Summitt 2000; Ustun 2005; Analysis 1.3).

It is not clear if the effect may be different depending on whether laparoscopic colposuspension is performed with sutures or with 
mesh and staples, according to the test for subgroup differences ( $P$ $=0.01$ and overlapping $95 \% \mathrm{Cls}$ ).

The analysis for objective cure rates between 18 months and five years showed no evidence of a difference between laparoscopic and open colposuspension, using random-effects analysis due to the different directions of effect in the two trials (RR $0.82,95 \% \mathrm{Cl}$ 0.41 to 1.63; 290 women; Burton 1997; Kitchener 2006; Analysis 1.4).

At five-year follow-up, there was no evidence of a difference in objective cure rates between laparoscopic and open colposuspension using random-effects analysis due to the different directions of effect in the two trials (RR $0.89,95 \% \mathrm{Cl} 0.28$ to $2.80 ; 107$ women; Burton 1997; Morris 2001; Analysis 1.5).

\section{Quality of life}

Five trials measured quality of life using a variety of questionnaires (Ankardal 2004; Ankardal 2005; Carey 2006; Cheon 2003; Kitchener 2006; Table 1). The evidence is summarised below.

One trial used the SF-36, SUDI (Short Urogenital Distress Inventory) and IIQ questionnaires (Carey 2006). Both the SUDI and IIQ scores equally improved postoperatively in the two groups but no further details were available.

Two trials used a VAS to assess symptoms of 'bother' caused and their impact on different quality of life domains (Ankardal 2004; Ankardal 2005). In one trial the improvement was greater in the open colposuspension group with regard to physical activity one year after surgery (Ankardal 2004).

One trial used a number of validated questionnaires (Kitchener 2006). These included SF-36, the Bristol Female Lower Urinary Tract Symptom Questionnaire (BFLUTS), Symptom Severity and Symptom Impact Index and the EQ-5D-3L. Kitchener 2006 reported results for the SF-36 and EQ-5D-3L and showed that both treatment arms had improved scores after two years with no evidence of a difference between groups.

One trial assessed quality of life but details of the instrument used and further results were lacking in the trial report (Cheon 2003).

\section{Surgical outcome measures}

\section{Repeat continence surgery}

In one trial, at five years' follow-up three out of 30 women (10\%) in the laparoscopic group in one trial had repeat continence surgery compared with none out of 30 in the open group (Burton 1997). None of the other trials reported this outcome.

\section{Pain or analgesia requirements}

Women who underwent a laparoscopic colposuspension appeared to have significantly less pain and needed less postoperative analgesia but the trials did not present data in a form suitable for quantitative synthesis (Burton 1997; Carey 2006; Cheon 2003; Fatthy 2001; Kitchener 2006; Tuygun 2006).

\section{Length of inpatient stay}

All trials, with the exception of Morris 2001, reported the length of hospital stay to be longer for open colposuspension. Eight trials reported data in such a way that could be analysed, favouring laparoscopic colposuspension due to a shorter hospital stay (MD -1.20 days, $95 \% \mathrm{Cl}-1.84$ to -0.56 ; 1142 women; Ankardal
2004; Ankardal 2005; Carey 2006; Cheon 2003; Kitchener 2006; Stangel-Wojcikiewicz 2008; Summitt 2000; Tuygun 2006; Analysis 1.6).

\section{Time to return to normal activity level}

Where reported, the time to return to normal activities was significantly longer for open colposuspension (MD -14.27 days, $95 \% \mathrm{Cl}$ -25.17 to -3.38 ; 401 women; Carey 2006; Cheon 2003; Fatthy 2001; Tuygun 2006; Analysis 1.7).

\section{Operation time}

Laparoscopic colposuspension with either sutures or with mesh and staples took significantly longer than open colposuspension (sutures: MD 25.27 minutes, 95\% CI 6.21 to 44.33; 549 women; mesh and staples MD 16.77 minutes; $95 \% \mathrm{Cl} 6.59$ to 26.95; 379 women; Ankardal 2004; Ankardal 2005; Carey 2006; Fatthy 2001; Su 1997; Summitt 2000; Tuygun 2006; Analysis 1.8). We analysed the data with a random-effects model because there was significant heterogeneity $\left(I^{2}=94 \%\right)$, probably due to a combination of factors such as the considerable variation in operation times reported in the trials, the different definitions of operation time used by the trial authors and the different levels of experience of the surgeons performing the operations.

\section{Blood loss}

Based on nine trials, the estimated blood loss was higher in the open groups (MD $-87.64 \mathrm{~mL}, 95 \% \mathrm{Cl}-141.70$ to -33.58 ; 940 women; Ankardal 2004; Burton 1997; Carey 2006; Cheon 2003; Fatthy 2001; Stangel-Wojcikiewicz 2008; Su 1997; Summitt 2000; Tuygun 2006; Analysis 1.9).

\section{Duration of catheterisation}

While six trials reported the mean duration of catheterisation, only four reported their data with standard deviations (Ankardal 2004; Cheon 2003; Su 1997; Tuygun 2006). It appeared that women undergoing laparoscopic colposuspension required less catheterisation time than those having open colposuspension, (MD -2.39 days, $95 \% \mathrm{Cl}-3.48$ to -1.30 ; 449 women; Analysis 1.10).

\section{Adverse effects}

\section{Perioperative complications}

Laparoscopic colposuspension may slightly reduce the risk of perioperative complications compared with open colposuspension (RR 0.67, $95 \% \mathrm{Cl} 0.47$ to 0.94; 1369 women; Ankardal 2004; Ankardal 2005; Burton 1997; Carey 2006; Cheon 2003; Fatthy 2001; Kitchener 2006; Su 1997; Summitt 2000; Tuygun 2006; Ustun 2005; low-quality evidence; Analysis 1.11; Summary of findings for the main comparison). The test for subgroup differences indicated little evidence of heterogeneity between subgroups, which could be due to different kinds of laparoscopic colposuspension $(P=0.60)$. Furthermore, the $95 \% \mathrm{Cls}$ of the two summary estimates overlapped closely, so it may be that laparoscopic colposuspension using sutures compared with open colposuspension does not have a different effect from laparoscopic colposuspension using mesh and staples.

In terms of bladder perforation, there may be similar or higher rates with laparoscopic colposuspension compared with open colposuspension (RR $1.72,95 \% \mathrm{Cl} 0.90$ to $3.29 ; 1311$ women; Ankardal 2004; Ankardal 2005; Burton 1997; Carey 2006; Cheon 2003; Fatthy 2001; Kitchener 2006; Stangel-Wojcikiewicz 2008; Tuygun 2006; Us- 
tun 2005; moderate-quality evidence; Analysis 1.12; Summary of findings for the main comparison).

With respect to the test for subgroup differences regarding laparoscopic colposuspension with sutures and laparoscopic colposuspension with mesh and staples, there was no evidence of heterogeneity $(P=0.29)$ and the $95 \% \mathrm{Cls}$ of the two summary estimates overlapped closely. Therefore, there is little indication that the effects may be different in these two subgroups. Two trials reported cases of laceration to the obturator vein during laparoscopic colposuspension (Carey 2006; Summitt 2000).

\section{De novo detrusor overactivity}

Whether laparoscopic colposuspension or open colposuspension is used probably makes little difference in terms of de novo detrusor overactivity within 18 months (RR $1.29,95 \% \mathrm{Cl} 0.72$ to $2.30 ; 472$ women; Burton 1997; Carey 2006; Cheon 2003; Fatthy 2001; Ustun 2005; moderate-quality evidence; Analysis 1.13). However, the confidence intervals are wide and cross the line of no effect, spanning both benefits and harms, so differences between the two procedures are not apparent.

It is uncertain whether laparoscopic colposuspension increases the risk of de novo detrusor overactivity in the long-term (RR for 18 months to 5 years $1.00,95 \% \mathrm{Cl} 0.07$ to 15.12 and RR for more than 5 years 1.22, $95 \% \mathrm{Cl} 0.40$ to 3.75; Burton 1997; Morris 2001; Analysis 1.13).

\section{Voiding dysfunction}

There is probably little difference between laparoscopic and open colposuspension in terms of voiding dysfunction (RR $0.81,95 \%$ Cl 0.50 to 1.31; 507 women; Burton 1997; Carey 2006; Cheon 2003; Stangel-Wojcikiewicz 2008; Ustun 2005; moderate-quality evidence; Analysis 1.14; Summary of findings for the main comparison). However, the confidence intervals are wide and cross the line of no effect, spanning both benefits and harms, so differences between the two procedures are not apparent.

\section{Laparoscopic colposuspension versus traditional sling procedures}

We did not find any eligible trials.

\section{Laparoscopic colposuspension versus midurethral sling procedures}

Nine trials investigated laparoscopic colposuspension with newer 'self-fixing' sling procedures (Adile 2001; Foote 2006; Maher 2004; Mirosh 2005; Paraiso 2004; Persson 2002; Samiee 2009; Ustun 2003; Valpas 2004). Within these nine trials there were variations in the techniques (TVT, TOT or SPARC slings) and type of material (sutures or mesh) used for both of the procedures. For this reason, we used subgroups within the comparison graphs. All trials reported data within 18 months and five of the them had follow-up at one year postoperatively (Foote 2006; Paraiso 2004; Persson 2002; Mirosh 2005; Valpas 2004). The ability to synthesise data was limited in some areas by the variation in tests and definitions used for subjective and objective outcomes. For this reason, we have reported some data in Table 2. A published supplementary version of one trial reported long-term follow-up (four to eight years) (Paraiso 2004).

\section{Primary outcomes}

\section{Subjective cure of urinary incontinence within 18 months}

The pooled RR for subjective cure of urinary incontinence within 18 months after laparoscopic colposuspension relative to midurethral slings was 0.91 (95\% Cl 0.80 to 1.02; 377 women; Foote 2006; Maher 2004; Persson 2002; Ustun 2003; Valpas 2004; Analysis 2.1). There may be little difference between laparoscopic colposuspension with sutures in terms of subjective cure compared to midurethral slings (RR 1.01, 95\% Cl 0.88 to 1.16; 256 women; Foote 2006; Maher 2004; Persson 2002; Ustun 2003; low-quality evidence; Analysis 2.1; Summary of findings 2). Open colposuspension may be more effective than laparoscopic colposuspension with mesh in terms of subjective cure (RR $0.71,95 \% \mathrm{Cl} 0.55$ to $0.91 ; 121$ women; Valpas 2004; Analysis 2.1; Summary of findings 2; low-quality evidence). There was little evidence of heterogeneity $(P=0.02)$ and the $95 \% \mathrm{Cl}$ s of the two summary estimates overlapped closely. Therefore there is little indication that the effects may be different in these two subgroups.

\section{Subjective cure of urinary incontinence after 18 months and within five years}

At 18 months to five years' follow-up, based on one small trial, there was no evidence of a difference in subjective cure between laparoscopic colposuspension and midurethral slings (RR 1.18, 95\% Cl 0.36, 3.81; 53 women; Paraiso 2004).

\section{Subjective cure of urinary incontinence after five years}

None of the trials reported this outcome.

\section{Secondary outcomes}

\section{Women's observations}

Data from two small trials showed no evidence of a difference in urgency symptoms (de novo symptoms) between laparoscopic colposuspension and midurethral slings (RR $0.44,95 \% \mathrm{Cl} 0.13$ to 1.47 ; 201 women; Foote 2006; Valpas 2004; Analysis 2.2).

\section{Quantification of symptoms}

Data from two trials suggested that women who had laparoscopic colposuspension had fewer incontinence episodes per week than those who had midurethral slings (MD -1.40 episodes, $95 \% \mathrm{Cl}-2.07$ to -0.73 ; 150 women; Foote 2006; Paraiso 2004; Analysis 2.3).

One trial reported pad test data but not in a way suitable for analysis (Valpas 2004).

\section{Objective cure (clinicians' measures)}

Midurethral slings appear to be slightly better than laparoscopic colposuspension in terms of objective cure within 18 months (RR $0.8895 \% \mathrm{Cl} 0.81$ to 0.95 ; 575 women; Adile 2001; Foote 2006; Maher 2004; Paraiso 2004; Persson 2002; Ustun 2003; Valpas 2004; Analysis 2.4). It is not clear if the effect may be different depending on whether laparoscopic colposuspension is performed with sutures or with mesh, according to the test for subgroup differences $(\mathrm{P}=$ 0.01 and overlapping 95\% confidence intervals). Furthermore, we cannot draw firm conclusions because there was only one trial in the mesh and staples subgroup.

Samiee 2009 reported objective cure rates of $75 \%$ for laparoscopic colposuspension and $84.20 \%$ TOT, which was determined by no urinary leakage during stress and analysed with urodynamic eval- 
uation, However, they did not specify the method of laparoscopic colposuspension in the non-translated full-text of the paper.

\section{Quality of life}

Six trials measured quality of life using various validated instruments (UDI, IIQ, SF-36, KHQ and VAS; Foote 2006; Maher 2004; Mirosh 2005; Paraiso 2004; Samiee 2009; Valpas 2004). The trials collected quality-of-life evidence using a range of validated questionnaires and the data indicated little evidence of a difference between the groups (Table 2).

\section{Surgical outcome measures}

\section{Repeat continence surgery}

There may be lower rates of repeat continence surgery for laparoscopic colposuspension compared with midurethral slings, however, the confidence intervals are very wide and cross the line of no effect, spanning both benefits and harms, so differences between the two procedures are not apparent (low-quality evidence; Summary of findings 2). One trial reported that one out of 32 women and three out of 38 women underwent repeat continence surgery in the laparoscopic colposuspension and midurethral slings groups respectively (RR 0.40, 95\% Cl 0.04 to 3.62; 70 women; Persson 2002).

\section{Pain or analgesia requirements}

Only two trials assessed the use of postoperative analgesia and pain relief (Paraiso 2004; Valpas 2004). Valpas 2004 reported that the use and doses of analgesics were lower in the TVT group, whereas Paraiso 2004 found little difference between the length of time (in hours) that patient-controlled analgesia (PCA) was used in the groups. The data were unsuitable for meta-analysis.

\section{Length of inpatient stay}

Based on data from two trials, the length of inpatient stay was longer for women undergoing laparoscopic colposuspension than for those undergoing midurethral sling procedures (MD 1.06 days, $95 \% \mathrm{Cl} 0.59$ to 1.53 , 128 women; Maher 2004; Ustun 2003). When we included data from trials where we imputed standard deviations, the mean difference was greater and with narrower 95\% Cls (MD 1.18 days, $95 \% \mathrm{Cl} 0.82$ to 1.55 , 322 women; Foote 2006; Maher 2004; Mirosh 2005; Ustun 2003; Valpas 2004; Analysis 2.5).

\section{Time to return to normal activity level}

Where reported, the time to return to normal activities was longer for laparoscopic colposuspension (MD 7.14 days, 95\% Cl 4.60 to 9.67; 280 women; Foote 2006; Maher 2004; Valpas 2004; Analysis 2.6).

\section{Operation time}

Laparoscopic surgery took longer than midurethral sling surgery (MD 26.26 minutes, 95\% Cl 6.57 to 45.95; 198 women; Maher 2004; Persson 2002; Ustun 2003). However, it is unclear if this is a clinically important difference.

In analysing operation time, when we included the trials where we imputed standard deviations, the mean difference was greater and with narrower $95 \%$ Cls (MD 25.85 minutes, $95 \% \mathrm{Cl} 13.56$ to 38.13; 392 women; Foote 2006; Maher 2004; Mirosh 2005; Persson 2002; Ustun 2003; Valpas 2004; Analysis 2.7). We used a random-effects model to analyse the data because there was significant heterogeneity $\left(1^{2}=87 \%\right)$, probably due to a combination of factors such as the considerable variation in the operation times reported in the trials, the different definitions of operation time used by the trial authors and the different levels of experience of the surgeons performing the operations.

\section{Blood loss}

None of the trials reported this outcome.

\section{Duration of catheterisation}

Four trials reported the duration of indwelling catheterisation but the data were not suitable for meta-analysis (see Table 2).

\section{Adverse effects \\ Perioperative complications}

Seven of the trials reported perioperative complications (Adile 2001; Foote 2006; Mirosh 2005; Paraiso 2004; Persson 2000; Ustun 2003; Valpas 2004). There may be no evidence of a difference between laparoscopic colposuspension and midurethral slings in terms of perioperative complication rates (RR $0.99,95 \% \mathrm{Cl} 0.60$ to 1.64; 514 women; low-quality evidence; Analysis 2.8; Summary of findings 2). With respect to the test for subgroup differences regarding laparoscopic colposuspension with sutures and laparoscopic colposuspension with mesh and staples, there was no evidence of heterogeneity $(P=0.17)$ and the $95 \% \mathrm{Cls}$ of the two summary estimates overlapped. This suggests that there may be little difference in effects between these two subgroups but we cannot draw firm conclusions because there was only one trial in the mesh and staples group.

None of the trials reported bladder perforations.

\section{De novo detrusor overactivity}

There may be no evidence of a difference between laparoscopic colposuspension and midurethral slings in de novo detrusor overactivity within 18 months because we assessed the quality of evidence as low (RR 0.80, 95\% Cl 0.34 to 1.88; 326 women; Adile 2001; Maher 2004; Paraiso 2004; Ustun 2003; low-quality evidence; Analysis 2.9; Summary of findings 2).

\section{Voiding dysfunction}

There is probably little difference between laparoscopic colposuspension and midurethral slings in terms of voiding dysfunction (RR 1.06, 95\% Cl 0.47 to 2.41; 412; Foote 2006; Maher 2004; Paraiso 2004; Persson 2002; Valpas 2004; moderate-quality evidence; Analysis 2.10; Summary of findings 2). However, the confidence intervals are wide and cross the line of no effect, spanning both benefits and harms, so differences between the two procedures are not apparent.

With respect to the test for subgroup differences regarding laparoscopic colposuspension with sutures and laparoscopic colposuspension with mesh and staples, there was no evidence of heterogeneity $(P=0.77)$ and the $95 \% \mathrm{Cls}$ of the two summary estimates overlapped closely. This suggests that there may be little difference in effects between these two subgroups but we cannot draw firm conclusions because there was only one trial in the mesh and staples group.

\section{Laparoscopic colposuspension versus needle suspension}

We did not find any eligible trials. 


\section{Laparoscopic colposuspension versus anterior vaginal repair}

We did not find any eligible trials.

\section{Laparoscopic colposuspension versus periurethral injections}

We did not find any eligible trials.

\section{One method of laparoscopic colposuspension versus another}

Five trials (444 participants) looked at different methods of laparoscopic colposuspension (Ankardal 2005; Persson 2000; Ross 1996; Wallwiener 1995; Zullo 2001). One compared one double-bite suture with two single-bite sutures each side of the urethra (Persson 2000). Three compared mesh and staples with sutures (Ankardal 2005; Ross 1996; Zullo 2001). One trial compared two different methods of laparoscopic approach (Wallwiener 1995).

Wallwiener 1995 compared a transperitoneal approach with an extraperitoneal approach for laparoscopic colposuspension, and used a mixture of sutures or mesh stapler fixation; it was not clear which method of fixation they used with which operation. The sample size was small ( 22 women). Overall, 18 out of 22 women were subjectively and objectively cured; no data were reported per treatment group.

\section{Primary outcomes}

\section{Subjective cure of urinary incontinence within 18 months}

Laparoscopic colposuspension with two sutures versus laparoscopic colposuspension with one suture

Low-quality evidence from one trial indicated that there may be significantly more women reporting subjective cure after undergoing laparoscopic colposuspension with two sutures (72/81 women) than those undergoing the procedure with one suture (50/77 women), within 18 months of surgery (RR $1.37,95 \% \mathrm{Cl} 1.14$ to $1.64 ; 158$ women; Persson 2000; Summary of findings 3).

\section{Laparoscopic colposuspension with sutures versus laparoscopic} colposuspension with mesh and staples

One trial comparing sutures to mesh and staples did not report subjective measures of cure or improvement (Ross 1996). It is uncertain whether laparoscopic colposuspension with sutures leads to better subjective cure rates compared with laparoscopic colposuspension with mesh within 18 months (RR $1.28,95 \% \mathrm{Cl} 1.11$ to 1.47 ; 180 women; Ankardal 2005; Zullo 2001; very low-quality evidence; Analysis 3.1; Summary of findings 4). There was evidence of heterogeneity $\left(I^{2}=73 \%\right)$, which is unlikely to be attributable to differences between the trials since both had similar participant characteristics and both used VASs to assess subjective perception of incontinence. To address this heterogeneity, we performed a random-effects meta-analysis (RR 1.24, 95\% Cl 0.96 to 1.59), which suggests there may be little difference in terms of subjective cure when comparing sutures with mesh and staples.

\section{Subjective cure of urinary incontinence after 18 months and within five years}

Laparoscopic colposuspension with two sutures versus laparoscopic colposuspension with one suture

Not reported.
Laparoscopic colposuspension with sutures versus laparoscopic colposuspension with mesh and staples

The only trial comparing mesh and staples with sutures that also contained data beyond 18 months' follow-up reported that the subjective cure rate was significantly $(P<0.05)$ higher in the sutures group than in the mesh and staples group at both 24 and 36 months (Zullo 2001). This trial reported the subjective outcomes as subjective failure rates as opposed to subjective cure rates and evaluated them using a VAS. They reported that subjective failure rate was significantly $(P<0.05)$ lower in the sutures group than in the mesh and staples group 24 months (20.0\% versus $36.7 \%$, respectively), and 36 months ( $33.3 \%$ versus $53.3 \%$, respectively) after surgery. The same study went on to conclude that laparoscopic colposuspension performed with sutures is more effective than laparoscopic colposuspension accomplished with the use of prolene meshes in the long term, and the use of prolene meshes should be avoided in the treatment of stress incontinence.

\section{Subjective cure of urinary incontinence after five years}

None of the studies reported this outcome.

\section{Secondary outcomes}

\section{Women's observations}

In one trial comparing one double-bite suture with two single-bite sutures, a higher proportion of women in the one-suture group reported postoperative urgency symptoms than in the two-suture group (6/78, 7.8\% compared to 4/83, 4.9\%; Persson 2000$)$.

\section{Quantification of symptoms}

None of the studies reported this outcome.

\section{Objective cure (clinicians' measures)}

In one trial comparing one double-bite suture with two single-bite sutures, the objective cure rate was significantly higher in the twosuture group than in the one-suture group (RR $1.42,95 \% \mathrm{Cl} 1.14$ to $1.77 ; 149$ women; Persson 2000).

All trials comparing mesh and staples with sutures defined objective failure as leakage observed on the clinical stress test. The random-effects meta-analysis, carried out because of the different directions of effect observed in the trials, indicated that there may be no difference within 18 months' follow-up between laparoscopic colposuspension with mesh and with sutures (RR 1.17, 95\% Cl 0.89 to 1.55; 243 women; Ankardal 2005; Ross 1996; Zullo 2001).

One small trial comparing mesh and staples with sutures presented data at three-year follow-up, which also indicated no evidence of a difference between the groups (RR $1.50,95 \% \mathrm{Cl} 0.83$ to $2.70 ; 52$ women; Zullo 2001).

\section{Quality of life}

None of the studies reported this outcome.

\section{Surgical outcome measures}

\section{Repeat continence surgery}

Based on low-quality evidence from a single trial, there may be little difference between laparoscopic colposuspension with one or two sutures in terms of repeat continence surgery. One woman in the two-suture group ( 80 women) had repeat continence surgery, 
compared to none in the one-suture group ( $\mathrm{RR} 0.35,95 \% \mathrm{Cl} 0.01$ to 8.37; 157 women; Persson 2000; Summary of findings 3).

We cannot be certain if there is any difference in the numbers of women undergoing repeat continence surgery between laparoscopic colposuspension with sutures (1/35 women) and laparoscopic colposuspension with mesh and sutures (1/34 women) because we assessed the quality of evidence as very low (RR 0.97, 95\% $\mathrm{Cl} 0.06$ to 14.91; Ross 1996; Summary of findings 4).

\section{Pain or analgesia requirements}

None of the studies reported this outcome.

\section{Length of inpatient stay}

In one trial comparing one double-bite suture with two single-bite sutures, the median length of hospital stay was 1.7 days in both groups (Persson 2000).

In two trials comparing mesh and staples with sutures, length of hospital stay was the same regardless of whether sutures or mesh were used (Ross 1996; Zullo 2001). In one trial, the length of hospital stay was shorter in the mesh group (mean 2.1, SD 1.3 days) than in the sutures group (mean 3.3, SD 2.5 days; Ankardal 2005).

\section{Time to return to normal activity level}

None of the studies reported this outcome.

\section{Operation time}

In one trial comparing one double-bite suture with two single-bite sutures, the median operating time was 17 minutes longer among those allocated to two sutures (Persson 2000).

Ankardal 2005 reported longer operating time for sutures (mean 84, SD 30 minutes) compared to mesh and staples (74, SD 25 minutes). The same trial also reported longer catheterisation time for sutures (mean 6.2, SD 9.2 days) than for mesh and staples (mean 1.9, SD 2.5 days).

\section{Blood loss}

None of the studies reported this outcome.

\section{Duration of catheterisation}

In one trial comparing one double-bite suture with two single-bite sutures, the mean time of catheterisation was 2.5 days in both groups (Persson 2000).

\section{Adverse effects}

\section{Perioperative surgical complications}

In one trial comparing one double-bite suture with two single-bite sutures, there may be no evidence of a difference between the one-suture and two-suture groups in terms of perioperative surgical complications, totaling $15 / 78$ and $14 / 83$ in the one-suture and two-suture groups respectively (RR $0.88,95 \% \mathrm{Cl} 0.45$ to $1.70 ; 161$ women; low-quality evidence; Persson 2000; Summary of findings $3)$.

Persson 2000 did not report bladder perforations for laparoscopic colposuspension with one suture versus two sutures.

There may be a greater risk of perioperative complications with laparoscopic colposuspension using sutures versus laparoscopic col- posuspension using mesh (RR 1.94, 95\% $\mathrm{Cl} 1.09$ to $3.48 ; 260$ women; Ankardal 2005; Ross 1996; Zullo 2001; low-quality evidence; Summary of findings 4).

In two trials, there were more bladder perforations in the suture group than in the mesh group (2 versus 1 (Ankardal 2005); 4 versus 1 (Ross 1996). In one trial, there was one in each of the groups (Zullo 2001).

\section{De novo detrusor overactivity}

De novo detrusor activity was not reported for laparoscopic colposuspension with one suture versus laparoscopic colposuspension with two sutures.

There may be no evidence of a difference between laparoscopic colposuspension with sutures and laparoscopic colposuspension with mesh and sutures in the number of women with de novo detrusor overactivity (RR $0.72,95 \% \mathrm{Cl} 0.17$ to $3.06 ; 122$ women; Ross 1996; Zullo 2001; low-quality evidence; Analysis 3.4; Summary of findings 4).

\section{Voiding dysfunction}

One trial comparing one double-bite suture with two single-bite sutures suggests that there may be no evidence of a difference between the groups in the numbers of women with voiding dysfunction; $1 / 77$ and $3 / 81$ in the one-suture and two-sutures groups respectively (RR 2.82, 95\% Cl 0.30 to 26.54; 158 women; Persson 2000; low-quality evidence; Summary of findings 3 ).

Voiding dysfunction was not reported for laparoscopic colposuspension with sutures compared with laparoscopic colposuspension with mesh and staples.

\section{Results of subgroup analyses}

\section{Open colposuspension using sutures versus laparoscopic colposuspension using mesh and staples}

Although subjective cure within 18 months seems to favour open colposuspension using sutures over laparoscopic colposuspension using mesh and staples, the quality of evidence was very low. Therefore, we are uncertain whether laparoscopic colposuspension using mesh and staples is better or worse than open colposuspension for subjective cure within 18 months (RR $0.75,95 \% \mathrm{Cl} 0.61$ to 0.93 ; 3 trials, 362 women; very low-quality evidence; see Analysis 1.1.2).

\section{DISCUSSION}

\section{Summary of main results}

The 26 eligible trials that we identified addressed only three of the prespecified comparisons. In particular, there were no comparisons with non-surgical management. The three comparisons addressed by the included trials in this review are: laparoscopic colposuspension versus open colposuspension; laparoscopic colposuspension versus other minimally invasive procedures (midurethral slings); and one type of laparoscopic colposuspension versus another. 
Laparoscopic colposuspension versus open colposuspension (abdominal surgery)

High-quality evidence indicates that laparoscopic colposuspension with sutures and open colposuspension are similarly effective in terms of subjective cure of urinary incontinence at up to 18 months' follow-up (Summary of findings for the main comparison). However, we cannot be certain of the effectiveness of laparoscopic colposuspension with mesh and staples compared to open colposuspension as the quality of evidence is very low (Summary of findings for the main comparison). In terms of subjective cure, we identified insufficient evidence to draw robust conclusions regarding the relative effectiveness of laparoscopic versus open colposuspension beyond 18 months after surgery.

In terms of objective cure up to 18 months after surgery, open colposuspension appears to be slightly better than laparoscopic colposuspension but beyond this point there may be little difference between the procedures. Trials collected evidence relating to quality of life using a range of validated questionnaires; these data indicated little difference between the groups but it was not possible to assess the quality of this evidence. It appears that laparoscopic colposuspension may take longer than open colposuspension but it is possible that this is offset by less blood loss, shorter inpatient stay, less catheterisation time and quicker return to daily activities. All of these are consistent with reviews of other laparoscopic operations (McCormack 2001; Sauerland 2010; Sauerland 2011).

With regard to possible harms, there is probably little difference between laparoscopic and open colposuspension in the de novo detrusor overactivity and voiding dysfunction but there may be similar or higher rates of bladder perforations with laparoscopic colposuspension (Summary of findings for the main comparison). Laparoscopic colposuspension may reduce the risk of perioperative complications relative to open colposuspension (Summary of findings for the main comparison). It is uncertain whether there is any difference between laparoscopic colposuspension and open colposuspension in the risk of requiring repeat continence surgery because the quality of evidence is very low (Summary of findings for the main comparison).

\section{Laparoscopic colposuspension versus midurethral sling procedures}

Low-quality evidence suggests there may be little difference between laparoscopic colposuspension compared with midurethral sling procedures in terms of subjective cure of urinary incontinence within 18 months after surgery, the risk of requiring repeat continence surgery, and the risk of perioperative complications and de novo detrusor overactivity (Summary of findings 2).

There is probably little difference between laparoscopic colposuspension and midurethral slings in terms of voiding dysfunction. Trials collected evidence relating to quality of life using a range of validated questionnaires; these data indicated little difference between the groups and it was not possible to assess the quality of this evidence. Bladder perforations were not reported by the studies.

In terms of objective cure up to 18 months after surgery, laparoscopic colposuspension may be slighter better than midurethral slings. There may be little difference between the two kinds of procedure in terms of objective measures of incontinence and pain or analgesia requirements. There may however be lower rates of repeat continence surgery with laparoscopic surgery although this is based on data from one small trial. It may be that laparoscopic colposuspension requires a longer operating time, longer inpatient stay and a longer time to return to normal activity levels than midurethral sling procedures. Nevertheless, it is important to consider the possible impact of the surgical learning curve in the context of surgical outcomes.

\section{One method of laparoscopic colposuspension against another}

Low-quality evidence suggests that laparoscopic colposuspension with two sutures may be more effective than one suture in terms of subjective cure of urinary incontinence within 18 months after surgery. However, there may be little difference between one and two sutures in terms of adverse effects or the risk of requiring repeat continence surgery, the number of perioperative complications, and voiding dysfunction (Summary of findings 3 ). Trials did not report quality of life, bladder perforations or de novo detrusor activity.

We are uncertain whether there is any difference between laparoscopic colposuspension with sutures or mesh and staples in terms of subjective cure of urinary incontinence within 18 months or number requiring repeat continence surgery, as the quality of evidence was very low (Summary of findings 4). There may be no difference between using sutures or mesh and staples in terms of number of perioperative complications and de novo detrusor overactivity (Summary of findings 4). The trials did not report quality of life or voiding dysfunction. The limited quantity and low quality of available evidence means that we cannot be certain whether laparoscopic colposuspension with sutures or with mesh and staples is more effective in terms of other patient- or clinician-reported outcomes.

Insufficient evidence means that we cannot draw any conclusions regarding the relative benefits or risks of laparoscopic colposuspension with either the transperitoneal or extraperitoneal approaches.

\section{Brief economic commentary}

A cost-effectiveness analysis by Dumville 2006, alongside a RCT compared open colposuspension with laparoscopic colposuspension in women with SUI in the UK. Dumville 2006 conducted the cost analysis from the perspective of the UK National Health Service (NHS), and healthcare resource use data (2002 to 2003, GBP) relating to the surgery, associated hospital stay and first six months after hospital discharge were collected prospectively for each participant. The data required for the calculation of quality adjusted life years (QALYS) were collected prospectively using the EQ-5D-3L questionnaire at baseline, 6,12 and 24 months. The economic evaluation was for both a six-month and up-to-24-month time horizon. Healthcare resource use over six-month follow-up resulted in costs of GBP 1805 for the laparoscopic arm and GBP 1433 for the open arm (differential mean cost GBP 372, 95\% credibility interval (Crl) 274 to 471). At six months, QALYs were slightly higher on average in the laparoscopic arm relative to the open arm $(0.005$, $95 \% \mathrm{Crl}-0.012$ to 0.023$)$. On average, the incremental cost per extra QALY provided by the laparoscopic approach was GBP 74,400 at six months. At 24 months, the laparoscopic arm again had higher mean QALYs compared to the open surgery group $(0.04,95 \% \mathrm{Crl}-0.009$ to 0.086$)$. If the laparoscopic colposuspension did not incur any significant additional costs after six months compared with open colposuspension, then the incremental cost per extra QALY reduced to GBP 9300 at 24 months. The probability that laparoscopic col- 
posuspension is cost-effective was $86 \%$ when the decision maker was willing to pay up to GBP 30,000 for an additional QALY. Dumville 2006 concluded that laparoscopic colposuspension is not cost-effective when compared with open colposuspension during the first six months but the additional QALYs might be judged to be worth the additional cost after 24-months' follow-up.

Valpas 2006 reported a cost-effectiveness analysis alongside a RCT that compared laparoscopic mesh colposuspension with TVT as a primary surgical treatment in women with stress urinary incontinence over a follow-up period of one year in Finland. The primary outcome was negative stress test and 48-hour pad test $(<8 \mathrm{~g} / 48 \mathrm{~h})$ and secondary outcomes were health-related quality of life. These were collected prospectively during the main period of hospitalisation, six weeks after surgery and after one year of follow-up. Cost items included costs of the treatments in each treatment arm, other hospital costs and productivity costs.

Primary and secondary outcomes in the TVT group were significantly better than laparoscopic mesh colposuspension as measured by the negative stress test (60 versus $29 ; 95 \% \mathrm{Cl}$ for change between the groups 12.7 to 43.9$)$, VAS $(0=$ no inconvenience at all; $10=\max -$ imal inconvenience; 0.8 versus $2.4 ; 95 \% \mathrm{Cl}$ for change between the groups 0.65 to 2.07 ) and Urinary Incontinence Severity Score (UISS; 1.1 versus $2.8 ; 95 \% \mathrm{Cl}$ for change between the groups 0.27 to 2.94 ). The between-group difference in the 48-hour pad test did not reach statistical significance ( 3 versus $12.4 ; 95 \% \mathrm{Cl}$ for change between the groups -2.8 to $30.4 ; \mathrm{P}=0.105)$. The total costs per participant at one year of follow-up for laparoscopic mesh colposuspension was EUR 3262 while TVT cost EUR 2081 (2000 EUR). Valpas 2006 concluded that when the VAS or UISS are used as the outcome measure, TVT is more cost-effective than laparoscopic mesh colposuspension over a follow-up period of one year $(P<0.0001)$.

Another cost-effectiveness analysis compared TVT with Burch colposuspension, laparoscopic colposuspension, traditional suburethral retropubic sling procedure and injectables. Cody 2003 utilised clinical data from a systematic review of RCTs conducted up to mid-2002 and the modelled results for a time horizon of up to 10 years. The analysis of costs and resources used was based on the UK payer's perspective (UK NHS). Based on clinical evidence, this study assumed that traditional sling effectiveness was equivalent to open colposuspension, that the effectiveness of laparoscopic colposuspension was equivalent to or possibly worse than open colposuspension (which is consistent with the findings of this review; see Summary of findings for the main comparison), and that use of injectables was the least effective procedure. This study reported the cost (2001 GBP) to be GBP 1058 per woman with an average of 2.9 days hospital stay for TVT, GBP 1317 per woman and average hospital stay of 4.6 days for laparoscopic colposuspension, GBP 1301 per woman and average hospital stay of 7.1 days for open colposuspension, GBP 1340 per woman and average hospital stay of 7.2 days for traditional sling and GBP 1305 per woman with an average hospital stay of two days for injectables. The study concluded that TVT was more likely to be considered cost-effective compared with the other surgical procedures based on the assumptions that traditional slings have the same effectiveness as open colposuspension and are also more costly; that laparoscopic colposuspension has the same or lower effectiveness as open colposuspension and similar costs; and that injectable agents are less effective than TVT but of greater cost.
We did not subject these identified economic evaluations to critical appraisal and we do not attempt to draw any firm or general conclusions regarding the relative costs or efficiency of laparoscopic colposuspension in treatment of stress urinary incontinence.

\section{Overall completeness and applicability of evidence}

We did not identify any relevant trials comparing laparoscopic colposuspension to non-surgical management or to anterior vaginal repair or to traditional sling procedures. Therefore, we cannot know if laparoscopic colposuspension may be better or worse than these other treatments.

It is worth noting that 11 of 25 included trials did not report women's subjective assessment of cure of incontinence. Furthermore, the methods of measuring subjective cure and quality of life varied, which may have some effect on the applicability of our findings. The paucity of long-term follow-up data and the lack of standardisation in how outcomes were both measured and reported across all of the trials still means that we remain uncertain about the effectiveness of laparoscopic colposuspension beyond 18 months. In addition, we did not identify sufficient evidence about the cost-effectiveness of laparoscopic colposuspension.

However, the trials identified here have provided evidence for some areas of clinical uncertainty. The findings presented here are based on evidence from interventions and trial populations that are largely representative of clinical practice. Furthermore, we can be confident that our comprehensive search strategies and data collection were sufficient to identify all the available evidence, notwithstanding the inherent limitations of searching bibliographic databases.

\section{Quality of the evidence}

Methodological assessment plays a crucial role in determining the quality of evidence supporting the estimated size of treatment effects of any intervention. In this review, we assessed the methodological flaws of the included trials, using the reports of the trials. Therefore, our judgement of methodological quality and hence the quality of effect estimates was influenced by the quality of reporting.

With regards to attrition bias, the rates of withdrawals and losses to follow-up were high in some of the included trials but with small differences in rates within treatment groups. In terms of size, most of the included trials were small, meaning that a high attrition rate would result in underpowering the trials and an increased risk of type II error (false negative results). A common problem with most of the included trials was incomplete reporting, particularly with respect to the trial methods and data. Thus, we assessed some risk of bias domains 'unclear' due to incomplete reporting of methods.

The quality of evidence presented here is generally low, largely due to risk of bias attributable to suboptimal randomisation and allocation procedures and to insufficient numbers of trial participants, making the trials underpowered. Furthermore, the trials often do not present their findings transparently and with useable data. However, we identified little indication of publication bias or indirectness.

\section{Potential biases in the review process}

To reduce the risk of bias in the process of identifying relevant evidence we searched all relevant bibliographic databases with a com- 
prehensive search strategy, broad inclusion criteria and without any language restrictions.

In this updated review, we identified outcomes for the 'Summary of findings' tables. As the review authors were already aware of the trials that were included in the previously published version of the review, it could have an impact on the outcomes selected, which could be a potential source of bias in this current update of the review.

\section{Agreements and disagreements with other studies or reviews}

Our findings relating to laparoscopic versus open colposuspension differ substantially from those of a narrative non-systematic review of the management of urinary incontinence in women, which found laparoscopic colposuspension to be $20 \%$ less successful than open colposuspension (Thakar 2000). Furthermore, a long-term comparative study suggested the subjective cure rates at 10 years after surgery were higher in women undergoing laparoscopic colposuspension than open colposuspension (Barr 2009).

Broadly speaking, our findings agree with the conclusions of clinical guidelines in the UK, which recommend that colposuspension (either open or laparoscopic) is offered as one of the routine procedures for stress urinary incontinence (NICE 2019). The UK guideline concludes that open and laparoscopic colposuspension are equally effective but that there may be a slightly higher risk of bladder injury with the laparoscopic approach. Our findings suggest that, overall, there is probably a similar risk of complications and adverse effects between laparoscopic and open colposuspension.

\section{AUTHORS' CONCLUSIONS}

\section{Implications for practice}

In this review we have tried to answer several clinical questions. We cannot tell from the available evidence whether laparoscopic colposuspension is better than no treatment, sham treatment, conservative interventions, traditional sling procedures, needle suspension, anterior vaginal repair or periurethral injections as we did not identify any trials investigating these trials.

Moderate-quality evidence suggests that laparoscopic colposuspension and open colposuspension are likely to be similar in terms of women's subjective cure of urinary incontinence, at least in the short-term. However, the very low-quality evidence means we are uncertain if there is any difference between laparoscopic and open colposuspension in the numbers of women requiring repeat continence surgery after laparoscopic colposuspension.

Low-quality evidence suggests laparoscopic colposuspension and midurethral slings may be similar in terms of women's subjective cure of urinary incontinence, at least in the short-term. The two procedures may also be similar in terms of the number of women requiring repeat continence surgery. We cannot tell if there is any difference between laparoscopic colposuspension and midurethral sling procedures in terms of quality of life.

Low-quality evidence suggests that laparoscopic colposuspension with two sutures may be more effective than one suture in terms of subjective cure of urinary incontinence but there may be little difference when laparoscopic colposuspension with sutures is compared with laparoscopic colposuspension with mesh and sta- ples. Low-quality evidence suggests there may be little difference between one or two sutures in the numbers of women requiring repeat continence surgery. We cannot tell from the available evidence if there are any differences between sutures and mesh and staples in terms of quality of life or the numbers of women requiring repeat continence surgery. Nor can we tell from the available evidence if there are any differences in outcomes between the transperitoneal or extraperitoneal approaches.

Low-quality evidence suggests the risk of perioperative complications and de novo detrusor overactivity may be similar when laparoscopic colposuspension is compared to open colposuspension or to midurethral sling procedures. The risk of adverse effects may also be similar when laparoscopic colposuspension with one suture is compared to laparoscopic colposuspension with two sutures. We cannot be certain about the relative risk of adverse effects when comparing any other kinds of laparoscopic colposuspension.

In the context of current safety concerns regarding the use of tapes in continence surgery (Scottish Government 2017), the Food and Drug Administration (FDA) reclassifying urogynecologic surgical mesh instrumentation from class I medical devices (low risk) into class II (intermediate risk; Federal Register 2017), and the recent publication from the European Parliament and the Council of the European Union proposing to reclassify these implantable device procedures from a class II device (medium risk) into class III device (high risk; Regulation (EU) 2017), it is particularly important that other surgical options, such as laparoscopic colposuspension, are thoroughly investigated using robust methods to ensure women and their healthcare providers can make informed decisions regarding treatment.

\section{Implications for research}

There is a need for well-designed randomised controlled trials with adequate sample sizes to assess the effectiveness of laparoscopic colposuspension in comparison with other surgical and non-surgical management options. Further recruitment to ongoing trials should be strongly encouraged and good reporting is needed to make these trials worthwhile. In particular, long-term follow-up of completed trials would provide more reliable information on both effectiveness (in terms of women's persistent or recurrent incontinence and need for repeat continence surgery) and adverse effects.

Future trials should report standardised subjective measures of cure or improvement. Objective outcomes should include repeat continence surgery and economic or cost-effectiveness measures. Furthermore, data should be reported in full for all outcomes that are measured in a trial.

Surgical trials related to urinary incontinence should systematically address, and report in usable form, surgical morbidity outcomes such as adverse perioperative events, pain scores, length of hospital stay, time to return to normal activities, development of urgency symptoms or detrusor overactivity and, especially, the need for repeat surgery or alternative interventions.

Long-term follow-up is essential for the proper evaluation of incontinence management and this should be included in all trials of laparoscopic colposuspension. 


\section{ACK N OWLEDGEMENTS}

We are grateful to the editors and peer referees who have provided valuable comments on drafts of this update and to Sheila Wallace for her help with the searches. We are also grateful to Dr Karen Boyd for providing information about her trial. We would like to acknowledge the work of all contributors to previous versions of the review, particularly Don Wilson who was responsible for the review from its inception.

An earlier version of this review was part of a project to add brief economic commentaries to Cochrane Incontinence's reviews on surgery for urinary incontinence in women (Dean 2017). This project was supported by the National Institute for Health Research (NIHR), via the Cochrane Review Incentive Scheme 2016. 


\section{REFERE N CES}

\section{References to studies included in this review}

Adile 2001 \{published data only\}

* Adile B, Cucinella G, Gugliotta G, Lo BA, Grifo S, Caputo A. A prospective randomised study of Burch laparoscopy versus tension-free vaginal tape: 2 year follow-up [Studio prospettico randomizzato Burch laparoscopica vs TVT. Follow-up a 2 anni]. Urogynaecologia International Journal 2001;15(1 Suppl):121-2. [ISSN 1121-3086; sri-incont13093]

Adile B, Granese R, Lo Bue A, Gugliotta G, Cardella AM, Adile C. A prospective randomized study comparing laparoscopic Burch versus TVT. Short and long term follow-up. International Continence Society, 33rd Annual Meeting; 2003 Oct 5-9; Florence, Italy. 2003:563. [sr-incont17164]

Cucinella G, Adile B, Gugliotta G, Lo Bue A, Grifo S, Caputo A. A prospective randomized study comparing laparoscopic Burch versus TVT. Two years follow-up (Abstract). International Urogynecology Journal 2001;12(Suppl 3):107. [sr-incont14358]

\section{Ankardal 2004 \{published data only\}}

Ankardal M. Evaluation of Surgical Methods for Treatment of Female Stress Urinary Incontinence [Doctoral thesis]. Gothenburg (Sweden): University of Gothenburg, 2005. [srincont73958]

Ankardal M, Crafoord K, Ekerydh A, Ellstrom M, Franzen K, Olsson $\mathrm{J}-\mathrm{H}$, et al. Burch colposuspension by laparoscopic or abdominal approach: report from a randomised study (Abstract number 302). International Continence Society (ICS), 31st Annual Meeting; 2001 Sept 18-21; Seoul, Korea. 2001. [srincont14383]

* Ankardal M, Ekerydh A, Crafoord K, Milsom I, Stjerndahl JH, Engh ME. A randomised trial comparing open Burch colposuspension using sutures with laparoscopic colposuspension using mesh and staples in women with stress urinary incontinence. BJOG 2004;111(9):974-81. [srincont17915]

Ankardal M, Jarbrink K, Milsom I, Heiwall B, LaustenThomsen N, Ellstrom-Engh M. Comparison of health care costs for open Burch colposuspension, laparoscopic colposuspension and tension-free vaginal tape in the treatment of female urinary incontinence. Neurourology and Urodynamics 2007;26(6):761-6. [sr-incont23845]

\section{Ankardal 2005 \{published data only\}}

Ankardal M. Evaluation of Surgical Methods for Treatment of Female Stress Urinary Incontinence [Doctoral thesis]. Gothenburg (Sweden): University of Gothenburg, 2005. [srincont73958]

Ankardal M, Jarbrink K, Milsom I, Heiwall B, LaustenThomsen N, Ellstrom-Engh M. Comparison of health care costs for open Burch colposuspension, laparoscopic colposuspension and tension-free vaginal tape in the treatment of female urinary incontinence. Neurourology and Urodynamics 2007;26(6):761-6. [sr-incont23845]
* Ankardal M, Milsom I, Stjerndahl JH, Engh ME. A three-armed randomized trial comparing open Burch colposuspension using sutures with laparoscopic colposuspension using sutures and laparoscopic colposuspension using mesh and staples in women with stress urinary incontinence. Acta Obstetricia et Gynecologica Scandinavica 2005;84(8):773-9. [sr-incont20624]

\section{Burton 1997 \{published and unpublished data\}}

Burton G. A five year prospective randomised urodynamic study comparing open and laparoscopic colposuspension. Neurourology and Urodynamics. 18 1999; Vol. 18, issue 4:295-6. [sr-incont9875]

Burton G. A five year prospective randomised urodynamic study comparing open and laparoscopic colposuspension (Abstract). International Urogynecology Journal of Pelvic Floor Dysfunction 1999;10(Suppl 1):44-5. [sr-incont9841]

Burton G. A randomised comparison of laparoscopic and open colposuspension. Neurourology and Urodynamics 1994;13(4):497-8. [sr-incont2684]

* Burton G. A three year prospective randomised urodynamic study comparing open and laparoscopic colposuspension. Neurourology and Urodynamics 1997;16(5):353-4. [srincont5836]

\section{Carey 2006 \{published data only\}}

Carey M, Maher CF, Rosamilia A, Dwyer P, Cornish A, Murray C, et al. Laparoscopic versus open colposuspension - early results of a single blind prospective randomized control trial. International Continence Society (ICS), 29th Annual Meeting; 1999 Aug 23-26; Denver (CO). 1999:224-5. [sr-incont8023]

Carey M, Rosamilia A, Dwyer P, Cornish A, Murray C, Ugoni A, et al. Laparoscopic versus open colposuspension: a prospective multicentre randomised single-blind comparison. Neurourology and Urodynamics 2000;19(4):389-91. [sr-incont9868]

* Carey MP, Goh JT, Rosamilia A, Cornish A, Gordon I, Hawthorne G, et al. Laparoscopic versus open Burch colposuspension: a randomised controlled trial [see comment]. BJOG 2006;113(9):999-1006. [sr-incont22334]

Carey MP, Maher CF, Rosamilla A, Cornish A, Ugoni A. Open or laparoscopic colposuspension - a prospective single blinded randomised control trial. Annual Meeting of the Royal Australian and New Zealand College of Obstetrics and Gynaecology. 2000. [sr-incont12089]

Carey MP, Rosamilia A, Maher C, Tsaltas J. Laparoscopic versus open colposuspension - results of a single blind prospective randomized control trial (Abstract number P5). IX Annual Scientific Meeting of the Australian Gynaecological Endoscopic Society; 1999 May 27-29; Adelaide, Australia. 1999:51. [srincont18194]

Cornish A, Carey M. Open versus laparoscopic Burch colposuspension: a randomised controlled trial [Laparoscopic versus open colposuspension for women with stress urinary incontinence: a prospective multicentre randomised single 
blind comparison of urodynamic cure of stress urinary incontinence at 6 months following surgery]. anzctr.org.au/ ACTRN12605000439640.aspx (first received 15 August 2005). [ACTRN12605000439640; sr-incont64630]

Cornish A, Fynes M, Harmer C, Hawthorne G, Rosamillia A, Carey $M$, et al. The genitourinary treatment satisfaction score for continence surgery (Abstract number 83). International Continence Society (ICS), 31st Annual Meeting; 2001 Sept 18-21; Seoul, Korea. 2001. [sr-incont14493]

\section{Cheon 2003 \{published data only\}}

* Cheon WC, Mak JH, Liu JY. Prospective randomised controlled trial comparing laparoscopic and open colposuspension. Hong Kong Medical Journal 2003;9(1):10-4. [sr-incont15758]

Mak JH, Cheon CW, Liu JY, Lee TK, Tong WM, Wong TH. Prospective randomized controlled trial comparing laparoscopic and open colposuspension (Abstract). 2nd Scientific Meeting of the Asian Society for Female Urology; 2000 Aug 26-27; Hong Kong. 2000:59-61. [sr-incont12120]

\section{Fatthy 2001 \{published data only\}}

Fatthy H, El Hao M, Samaha I, Abdallah K. Modified Burch colposuspension: laparoscopy versus laparotomy. Journal of the American Association of Gynecologic Laparoscopists 2001;8(1):99-106. [sr-incont11967]

\section{Foote 2006 \{published data only\}}

Foote A, Carne C, Lowndes C. Laparoscopic colposuspension vs vaginal mesh sling: a randomised prospective trial. Neurourology and Urodynamics 2004;23(5/6):434-5. [srincont19006]

* Foote AJ, Maughan V, Carne C. Laparoscopic colposuspension versus vaginal suburethral slingplasty: a randomised prospective trial. Australian \& New Zealand Journal of Obstetrics \& Gynaecology 2006;46(6):517-20. [sr-incont22592]

\section{Kitchener 2006 \{published data only\}}

Dumville JC, Manca A, Kitchener HC, Smith AR, Nelson L, Torgerson DJ, COLPO Study Group. Cost-effectiveness analysis of open colposuspension versus laparoscopic colposuspension in the treatment of urodynamic stress incontinence. BJOG 2006;113(9):1014-22. [ISRCTN14969683; sr-incont22332]

ISRCTN14969683. A randomised trial of open versus laparoscopic colposuspension for genuine stress incontinence. isrctn.org/ISRCTN14969683 (first received 25 October 2000). [ISRCTN14969683; TrialID.MRC COLPO; sr-incont16345]

* Kitchener HC, Dunn G, Lawton V, Reid F, Nelson L, Smith AR, COLPO Study Group. Laparoscopic versus open colposuspension--results of a prospective randomised controlled trial [see comment]. BJOG 2006;113(9):1007-13. [ISRCTN14969683; sr-incont22333]

Reid FM, Smith AR, Dunn G. Which questionnaire? A psychometric evaluation of three patient-based outcome measures used to assess surgery for stress urinary incontinence. Neurourology and Urodynamics 2007;26(1):123-8. [srincont22577]
Smith A, Kitchener H, Dunne G, Torgerson D, Lawton V, Reid F, et al. A prospective randomised controlled trial of open and laparoscopic colposuspension. Neurourology and Urodynamics 2005;24(5/6):422-3. [sr-incont20986]

\section{Maher 2004 \{published data only\}}

Maher C, Qatawneh A, Baessler K, Cropper M, Schluter P. Laparoscopic colposuspension or tension-free vaginal tape for recurrent stress urinary incontinence and/or intrinsic sphincter deficiency - a randomised controlled trial. Neurourology and Urodynamics 2004;23(5/6):433-4. [sr-incont19005]

Mirosh 2005 \{published data only\}

Mirosh M, Epp A. TVT vs laparoscopic Burch colposuspension for the treatment of stress urinary incontinence (Abstract number 640). 35th Annual Meeting of the International Incontinence Society (ICS); 2005 Aug 28-Sep 2; Montreal, Canada. 2005. [srincont20990]

\section{Morris 2001 \{published data only\}}

Morris AR, Reilly ET, Hassan A, Ramsay IN, Hawthorn RJ. 5-7 year follow-up of a randomised trial comparing laparoscopic colposuspension (LC) and open colposuspension (OC) in the treatment of genuine stress incontinence. International Urogynecology Journal 2001;12(Suppl 3):S6. [sr-incont12582]

\section{Paraiso 2004 \{published data only\}}

Jelovsek JE, Barber MD, Karram MM, Walters MD, Paraiso MF. Randomised trial of laparoscopic Burch colposuspension versus tension-free vaginal tape: long-term follow up. BJOG 2008;115(2):219-225, discussion 225. [sr-incont26265]

Paraiso MF, Walters M, Karram M, Barber M. Laparoscopic Burch colposuspension versus the tension-free vaginal tape procedure: a randomized clinical trial (Abstract). Neurourology and Urodynamics 2003;22(5):487-8. [sr-incont17108]

* Paraiso MF, Walters MD, Karram MM, Barber MD. Laparoscopic Burch colposuspension versus tension-free vaginal tape: a randomized trial. Obstetrics and Gynecology 2004;104(6):1249-58. [sr-incont19401]

\section{Persson 2000 \{published data only\}}

Persson J, Wolner-Hanssen P. Laparoscopic Burch colposuspension for stress urinary incontinence: a randomized comparison of one or two sutures on each side of the urethra. Obstetrics and Gynecology 2000;95(1):151-5. [sr-incont9014]

\section{Persson 2002 \{published data only\}}

* Persson J. Stress Urinary Incontinence Among Women: Aspects of Risk Factors, Evaluation and Surgical Treatment [PhD thesis]. Lund, Sweden: Department of Obstetrics and Gynecology, Lund University, 2001:1-61. [sr-incont16386]

Persson J, Teleman P, Eten-Bergquist C, Wolner-Hanssen P. Costanalyses based on a prospective, randomised study comparing laparoscopic colposuspension with tension-free vaginal tape procedure. Acta Obstetricia et Gynecologica Scandinavica 2002;81(11):1066-73. [sr-incont14362] 


\section{Ross 1996 \{published data only\}}

Ross J. Two techniques of laparoscopic Burch repair for stress incontinence: a prospective, randomized study. Journal of the American Association of Gynecologic Laparoscopists 1996;3(3):351-7. [sr-incont5658]

Samiee 2009 \{published data only\}

Samiee H, Tavoli Z, Ghanbari Z, Poormand GH, Taslimi SH, Eslami $B$, et al. Treatment of urinary stress incontinence: laparoscopic Burch colposuspension versus transobturator tape procedure. Majallah-i Danishkadah-'i Pizishkī [Tehran University Medical Journal] 2009;67(9):629-36. [ISSN: 1683-1764; sr-incont43325]

\section{Stangel-Wojcikiewicz 2008 \{published data only\}}

Stangel-Wojcikiewicz K. Laparoscopic Burch colposuspension compared to laparotomy for treatment urinary stress incontinence (Abstract number 121). Neurourology and Urodynamics 2008;27(7):714. [sr-incont31857]

\section{Su 1997 \{published data only\}}

Su TH, Wang KG, Hsu CY, Wei HJ, Hong BK. Prospective comparison of laparoscopic and traditional colposuspensions in the treatment of genuine stress incontinence. Acta Obstetricia et Gynecologica Scandinavica 1997;6(76):576-82. [sr-incont5558]

\section{Summitt 2000 \{published data only\}}

Summitt RL, Lucente VL, Karram MM, Shull BL, Bent AE. Randomised comparison of laparoscopic and transabdominal Burch urethropexy for the treatment of genuine stress incontinence (Abstract). Obstetrics and Gynecology 2000;95(4 Suppl 1):2. [sr-incont11862]

\section{Tuygun 2006 \{published data only\}}

Tuygun C, Bakirtas H, Eroglu M, Alisir I, Zengin K, Imamoglu A. Comparison of two different surgical approaches in the treatment of stress urinary incontinence: open and laparoscopic Burch colposuspension. Türk Üroloji Derneği 2006;32(2):248-53. [sr-incont26724]

\section{Ustun 2003 \{published data only\}}

Ustun Y, Engin-Ustun Y, Gungor M, Tezcan S. Tensionfree vaginal tape compared with laparoscopic Burch urethropexy. Journal of the American Association of Gynecologic Laparoscopists 2003;10(3):386-9. [sr-incont16694]

\section{Ustun 2005 \{published data only\}}

Ustun Y, Engin-Ustun Y, Gungor M, Tezcan S. Randomized comparison of Burch urethropexy procedures concomitant with gynecologic operations. Gynecologic and Obstetric Investigation 2005;59(1):19-23. [sr-incont20187]

\section{Valpas 2004 \{published data only\}}

* Valpas A, Ala-Nissila S, Tomas E, Nilsson CG. TVT versus laparoscopic mesh colposuspension: 5-year follow-up results of a randomized clinical trial. International Urogynecology Journal 2015;26(1):57-63. [sr-incont64697]

Valpas A, Kivela A, Penttinen J, Kauko M, Kujansuu E, Tomas E, et al. Comparison of TVT and laparoscopic colposuspension in the treatment of stress urinary incontinence (Abstract). XXXIII
Congress of the Nordic Federation of Societies of Obstetricians and Gynecologists (NFOG); 2002 June 1-4; Umea, Sweden. 2002. [sr-incont14356]

Valpas A, Kivela A, Penttinen J, Kauko M, Kujansuu E, Tomas E, et al. Intra-operative and immediate post-operative results comparing tensionfree vaginal tape (TVT) and laparoscopic colposuspension ( $\mathrm{LC}$ ) in the treatment of female stress urinary incontinence (SUI) - a randomized clinical trial (Preliminary results). 10th Congress of the European Society for Gynaecological Endoscopy; 2001 Nov 21-24; Lisbon, Portugal. 2001:355-8. [sr-incont13460]

Valpas A, Kivela A, Penttinen J, Kauko M, Kujansuu E, Tomas E, et al. Tension-free vaginal tape and laparoscopic mesh colposuspension in the treatment of stress urinary incontinence: immediate outcome and complications--a randomized clinical trial. Acta Obstetricia et Gynecologica Scandinavica 2003;82(7):665-71. [sr-incont16587]

Valpas A, Kivela A, Penttinen J, Kujansuu E, Haarala M, Nilsson CG. Tension-free vaginal tape and laparoscopic mesh colposuspension for stress urinary incontinence. Obstetrics and Gynecology 2004;104(1):42-9. [sr-incont19322]

Valpas A, Rissanen P, Kujansuu E, Nilsson C. A cost-effectiveness analysis of tension-free vaginal tape procedure vs. laparoscopic mesh colposuspension for primary female stress incontinence - a randomised clinical trial. Neurourology and Urodynamics 2005;24(5/6):418-9. [sr-incont20987]

Valpas A, Rissanen P, Kujansuu E, Nilsson CG. A costeffectiveness analysis of tension-free vaginal tape versus laparoscopic mesh colposuspension for primary female stress incontinence. Acta Obstetricia et Gynecologica Scandinavica 2006;85(12):1485-90. [sr-incont22539]

Valpas AK, Rissanen P, Kujansuu E, Nilsson CG. In a randomised clinical trial tension-free vaginal tape is more cost-effective than laparoscopic colposuspension (Abstract number 111). International Urogynecology Journal 2005;16(Suppl 2):S58-9. [sr-incont29162]

\section{Wallwiener 1995 \{published data only\}}

* Wallwiener D, Grischke EM, Rimbach S, Maleika A, Bastert G. Endoscopic retropubic colposuspension: "Retziusscopy" versus laparoscopy--a reasonable enlargement of the operative spectrum in the management of recurrent stress incontinence?. Endoscopic Surgery and Allied Technologies 1995;3(2-3):115-8. [sr-incont2928]

Wallwiener D, Grischke EM, Rimbach S, Maleika A, Kaufmann M, Bastert G. Endoscopic retropubic colposuspension:

"Retziuscopy" versus laparoscopy - a reasonable enlargement of the operative spectrum in the management of recurrent stress incontinence? [Endoskopische kolposuspension ("Retziuskopie" versus laparoskopie). Eine sinnvolle erweiterung des operationsspektrum der stressinkontinenz?]. Geburtshilfe und Frauenheilkunde 1995;5(55):235-9. [srincont2996] 


\section{Zullo 2001 \{published data only\}}

Palomba S, Russo T, luzzolino D, Cosco C, Noia R, Arduino B, et al. Comparison between two laparoscopic retropubic urethropexy. Minerva Chirurgica 2002;57(3):323-9. [srincont14445]

Piccione F, Zullo F, Palomba S, Sena T, Giovinazzi F, Biamonte M, et al. Different techniques of laparoscopic Burch colposuspension. Italian Journal of Gynaecology \& Obstetrics 2001;13(1):10-3. [ISSN:1121-8339; sr-incont18049]

Zullo F, Morelli M, Russo T, Iuzzolino D, Palomba S. Two techniques of laparoscopic retropubic urethropexy. Journal of the American Association of Gynecologic Laparoscopists 2002;9(2):178-81. [sr-incont14687]

* Zullo F, Palomba S, Piccione F, Morelli M, Arduino B, Mastrantonio P. Laparoscopic Burch colposuspension: a randomized controlled trial comparing two transperitoneal surgical techniques. Obstetrics and Gynecology 2001;98(5 Pt 1):783-8. [sr-incont12169]

Zullo F, Palomba S, Russo T, Sbano FM, Falbo A, Morelli M, et al. Laparoscopic colposuspension using sutures or prolene meshes: a 3-year follow-up. European Journal of Obstetrics, Gynecology, and Reproductive Biology 2004;117(2):201-3. [srincont19421]

\section{References to studies excluded from this review}

Choi 2006 \{published data only\}

Choi SJ, Kim YH, Choi SH, Ki WS, Kim SA, Jung H. A prospective study of transobturator tension free tape (TOT) and laparoscopic Burch operation for stress urinary incontinence (Abstract number 462). International Urogynecology Journal 2006;17(Suppl 2):307. [sr-incont64442]

\section{Foote 2007 \{published data only\}}

Foote AJ, Moore KH. The cost of urogynaecological treatments: which are more cost-effective?. Australian \& New Zealand Journal of Obstetrics \& Gynaecology 2007;47(3):240-6. [srincont23787]

\section{ISRCTN44339585 \{published data only\}}

ISRCTN44339585. Laparoscopic treatment for female urinary incontinence. isrctn.org/ISRCTN44339585 (first received 23 January 2004). [ISRCTN44339585; sr-incont17206]

\section{Koster 1996 \{published data only\}}

Koster S, Volz J, Melchert F. Indications for 3 D laparoscopy in gynecology [Zur indikation der 3 D-laparoskopie in der gynaekologie]. Geburtshilfe und Frauenheilkunde 1996;56(8):431-3. [sr-incont6892]

\section{Lee 1997 \{published data only\}}

Lee YS, Kim JH, Seo JT. A comparison of laparoscopic versus open Burch procedure for stress urinary incontinence. International Urogynecology Journal of Pelvic Floor Dysfunction 1997;8(1 Suppl):S37. [sr-incont9822]

\section{Lernis 1997 \{published data only\}}

Lernis P, Pantekhis G, Kalakoutis G. Presentation of our experience with laparoscopic colposuspension (Burch) at Makarios Hospital, Nicosia, Cyprus. Acta Obstetricia et Gynecologica Scandinavica 1997;76 Suppl 167(1):14. [srincont6669]

NCT00573703 \{published data only\}

NCT00573703, Palomba S, Zullo F. Laparoscopic Burch colposuspension versus transobturatory tape for the treatment of female urinary stress incontinence [A comparison between laparoscopic Burch colposuspension and transobturatory tape (TOT) for the treatment of female urinary stress incontinence]. clinicaltrials.gov/show/NCT00573703 (first received 14 December 2007). [NCT00573703; sr-incont61582]

Prezioso 2013 \{published data only\}

*Prezioso D, lacono F, Di Lauro G, Illiano E, Romeo G, Ruffo A, et al. Retraction note: stress urinary incontinence: long-term results of laparoscopic Burch colposuspension. BMC Surgery 2016;16(1):26 [Retraction of: BMC Surgery 2013;13(Suppl 2):S38. doi: 10.1186/1471-2482-13-S2-S38. PMC3851039]. [PMC4848875; PUBMED: 27122153]

Prezioso D, Iacono F, Di Lauro G, Illiano E, Romeo G, Ruffo $A$, et al. Stress urinary incontinence: long-term results of laparoscopic Burch colposuspension. BMC Surgery 2013;13(Suppl 2):38 [Retraction in: BMC Surgery 2016;16(1):26. doi: 10.1186/s12893-016-0141-6. PMC4848875]. [sr-incont49424; PUBMED: 24268031]

\section{Salam 2004 \{published data only\}}

Salam TA. Laproscopic versus conventional surgical treatment of genuine urinary stress incontinence (Abstract number 4). Progres en Urologie 2004;14(3 Suppl 3):6. [sr-incont31091]

\section{Additional references}

\section{Abrams 2013}

Abrams P, Cardozo L, Khoury S, Wein A (eds). In: Abrams P, Cardozo L, Khoury S, Wein A editor(s). Incontinence: 5th International Consultation on Incontinence. Recommendations of the International Scientific Committee: evaluation and treatment of urinary incontinence, pelvic organ prolapse and faecal incontinence; 2012 Feb 23-25; Paris, France. Belgium: International Consultation on Urological Diseases (ICUD), 2013.

\section{Barr 2009}

Barr S, Reid FM, North CE, Hosker G, Smith AR. The long-term outcome of laparoscopic colposuspension: a 10-year cohort study. International Urogynecological Journal Pelvic Floor Dysfunction 2009;20(4):443-5.

\section{Birnbaum 2004}

Birnbaum HG, Leong SA, Oster EF, Kinchen K, Sun P. Cost of stress urinary incontinence: a claims data analysis. PharmacoEconomics 2004;22(2):95-105. [sr-incont39892]

\section{Botlero 2008}

Botlero R, Urquhart DM, Davis SR, Bell RJ. Prevalence and incidence of urinary incontinence in women: review of 
the literature and investigation of methodological issues. International Journal of Urology 2008;15(3):230-4.

\section{Chong 2011}

Chong EC, Khan AA, Anger JT. The financial burden of stress urinary incontinence among women in the United States. Current Urology Reports 2011;12(5):358-62. [sr-incont77976]

\section{Cody 2003}

Cody J, Wyness L, Wallace S, Glazener C, Kilonzo M, Stearns S, et al. Systematic review of the clinical effectiveness and costeffectiveness of tension-free vaginal tape for treatment of urinary stress incontinence. Health Technology Assessment (Winchester, England) 2003;7(21):iii, 1-189. [sr-incont16489]

\section{CRD 2015}

Centre for Reviews and Dissemination (CRD). CRD databases: search strategies. 2015. crd.york.ac.uk/crdweb/ searchstrategies.asp (accessed 10 August 2018).

\section{Deeks 2017}

Deeks JJ, Higgins JP, Altman DG (editors) on behalf of the Cochrane Statistical Methods Group. Chapter 9: Analysing data and undertaking meta-analyses. In: Higgins JPT, Churchill R, Chandler J, Cumpston MS (editors), Cochrane Handbook for Systematic Reviews of Interventions version 5.2.0 (updated June 2017), Cochrane, 2017. Available from www.training.cochrane.org/handbook.

\section{Dumville 2006}

Dumville JC, Manca A, Kitchener HC, Smith AR, Nelson L, Torgerson DJ, et al. Cost-effectiveness analysis of open colposuspension versus laparoscopic colposuspension in the treatment of urodynamic stress incontinence. BJOG 2006;113(9):1014-22. [ISRCTN14969683; sr-incont22332]

\section{EndNote 2018 [Computer program]}

Clarivate Analytics. EndNote. Version X8.2. Philadelphia (PA): Clarivate Analytics, 2018.

\section{Federal Register 2017}

Food, Drug Administration. Department of Health and Human Services (HHS). Obstetrical and gynecological devices; reclassification of surgical instrumentation for use with urogynecologic surgical mesh. Final order. Docket No. FDA-2014-N-0297. Federal Register (accessed 19 September 2018); Vol. 82, issue 4:1598-603. Available at: federalregister.gov/documents/2017/01/06/2016-31862/ obstetrical-and-gynecological-devices-reclassification-ofsurgical-instrumentation-for-use-with.

\section{Ford 2017}

Ford AA, Rogerson L, Cody JD, Aluko P, Ogah JA. Mid-urethral sling operations for stress urinary incontinence in women. Cochrane Database of Systematic Reviews 2017, Issue 7. [DOI: 10.1002/14651858.CD006375.pub4]

\section{Glazener 2017a}

Glazener CM, Cooper K, Mashayekhi A. Anterior vaginal repair for urinary incontinence in women. Cochrane
Database of Systematic Reviews 2017, Issue 7. [DOI: 10.1002/14651858.CD001755.pub2]

\section{Glazener 2017b}

Glazener CM, Cooper K, Mashayekhi A. Bladder neck needle suspension for urinary incontinence in women. Cochrane Database of Systematic Reviews 2017, Issue 7. [DOI: 10.1002/14651858.CD003636.pub4]

\section{Guyatt 2008}

Guyatt GH, Oxman AD, Kunz R, Vist GE, Falck-Ytter Y, Schünemann $\mathrm{HJ}$. What is "quality of evidence" and why is it important to clinicians?. BMJ 2008;336(7651):995.

\section{Haylen 2010}

Haylen BT, de Ridder D, Freeman RM, Swift SE, Berghmans B, Lee J, et al. An International Urogynecological Association (IUGA)/International Continence Society (ICS) joint report on the terminology for female pelvic floor dysfunction. Neurourology and Urodynamics 2010;29(1):4-20.

\section{Higgins 2003}

Higgins JP, Thompson SG, Deeks JJ, Altman DG. Measuring inconsistency in meta-analyses. BMJ 2003;327(7414):557-60. [DOI: 10.1136/bmj.327.7414.557]

\section{Higgins 2011a}

Higgins JP, Green S (editors). Cochrane Handbook for Systematic Reviews of Interventions Version 5.1.0 (updated March 2011). The Cochrane Collaboration, 2011. Available from handbook.cochrane.org.

\section{Higgins 2011b}

Higgins JP, Deeks JJ, Altman DG (editors). Chapter 16: Special topics in statistics. In: Higgins JPT, Green S (editors). Cochrane Handbook for Systematic Reviews of Interventions. Version 5.1.0 (updated March 2011). The Cochrane Collaboration, 2011. Available from handbook.cochrane.org.

\section{Higgins 2017}

Higgins JP, Altman DG, Sterne JA (editors). Chapter 8: Assessing risk of bias in included studies. In: Higgins JPT, Churchill R, Chandler J, Cumpston MS (editors), Cochrane Handbook for Systematic Reviews of Interventions version 5.2.0 (updated June 2017), Cochrane, 2017. Available from www.training.cochrane.org/handbook.

\section{Jarvis 1999}

Jarvis GJ, Bent A, Cortesse A, McGuire A, Milani R, Quartey J, et al. Surgical treatment for incontinence in adult women surgery of female lower genito-urinary fistulae. In: Abrams P, Khoury S, Wein A editor(s). Incontinence: 1st International Consultation on Incontinence. Recommendations of the International Scientific Committee: the evaluation and treatment of urinary incontinence. Vol. 15, Plymouth: Health Publication Limited, 1999:637-68.

\section{Kang 2015}

Kang D, Han J, Neuberger MM, Moy ML, Wallace SA, AlonsoCoello $P$, et al. Transurethral radiofrequency collagen denaturation for the treatment of women with urinary 
incontinence. Cochrane Database of Systematic Reviews 2015, Issue 3. [DOI: 10.1002/14651858.CD010217.pub2]

\section{Kilonzo 2004}

Kilonzo M, Vale L, Stearns SC, Grant A, Cody J, Glazener CM, et al. Cost effectiveness of tension-free vaginal tape for the surgical management of female stress incontinence. International Journal of Technology Assessment in Health Care 2004;20(4):455-63.

\section{Kirchin 2017}

Kirchin V, Page T, Keegan PE, Atiemo KO, Cody JD, McClinton S, et al. Urethral injection therapy for urinary incontinence in women. Cochrane Database of Systematic Reviews 2017, Issue 7. [DOI: 10.1002/14651858.CD003881.pub4]

\section{Kunkle 2015}

Kunkle CM, Hallock JL, Hu X, Blomquist J, Thung SF, Werner EF Cost utility analysis of urethral bulking agents versus midurethral sling in stress urinary incontinence. Female Pelvic Medicine \& Reconstructive Surgery 2015;21(3):154-9. [srincont70311]

\section{Lapitan 2017}

Lapitan MC, Cody JD, Mashayekhi A. Open retropubic colposuspension for urinary incontinence in women. Cochrane Database of Systematic Reviews 2017, Issue 7. [DOI: 10.1002/14651858.CD002912.pub7]

\section{MacArthur 2016}

MacArthur C, Wilson D, Herbison P, Lancashire RJ, Hagen S, Toozs-Hobson $P$, et al. Urinary incontinence persisting after childbirth: extent, delivery history, and effects in a 12-year longitudinal cohort study. BJOG 2016;123(6):1022-9.

\section{McCormack 2001}

McCormack K, Scott N, Go PM, Ross SJ, Grant A, the EU Hernia Trialists Collaboration. Laparoscopic techniques versus open techniques for inguinal hernia repair. Cochrane Database of Systematic Reviews 2003, Issue 1. [DOI: 10.1002/14651858.CD001785]

\section{Nambiar 2017}

Nambiar A, Cody JD, Jeffery ST, Aluko P. Single-incision sling operations for urinary incontinence in women. Cochrane Database of Systematic Reviews 2017, Issue 7. [DOI: 10.1002/14651858.CD008709.pub3]

\section{NICE 2019}

National Collaborating Centre for Women's and Children's Health, National Institute for Health and Care Excellence (NICE). Urinary incontinence in women: management. NICE Clinical Guideline (NG 123). Available from nice.org.uk/guidance/ng123. London, UK: Royal College of Obstetricians and Gynaecologists, April 2019.

\section{Papa Petros 2010}

Papa Petros PE. The Integral Theory System. A simplified clinical approach with illustrative case histories. Pelviperineology 2010;29(2):37-51.

\section{Regulation (EU) 2017}

Council of the European Union. Position of the Council at first reading with a view to the adoption of a Regulation of the European Parliament and of the Council on medical devices. Brussels, Belgium: European Commission; 2017 March 9. Document reference No.: $\operatorname{COM(2017)129/F1.~}$ 10728/16. Interinstitutional File: 2012/0266 (COD). Available at: ec.europa.eu/transparency/regdoc/rep/1/2017/EN/ COM-2017-129-F1-EN-MAIN-PART-1.PDF Page 117/143 (accessed 25 September 2018).

\section{Rehman 2017}

Rehman H, Bezerra CA, Bruschini H, Cody JD, Aluko P. Traditional suburethral sling operations for urinary incontinence in women. Cochrane Database of Systematic Reviews 2017, Issue 7. [DOI: 10.1002/14651858.CD001754.pub4]

\section{Review Manager 2014 [Computer program]}

Nordic Cochrane Centre, The Cochrane Collaboration. Review Manager 5 (RevMan 5). Version 5.3. Copenhagen: Nordic Cochrane Centre, The Cochrane Collaboration, 2014.

\section{Sauerland 2010}

Sauerland S, Jaschinski T, Neugebauer EA. Laparoscopic versus open surgery for suspected appendicitis. Cochrane Database of Systematic Reviews 2010, Issue 10. [DOI: 10.1002/14651858.CD001546.pub3]

\section{Sauerland 2011}

Sauerland S, Walgenbach M, Habermalz B, Seiler CM, Miserez M. Laparoscopic versus open surgical techniques for ventral or incisional hernia repair. Cochrane Database of Systematic Reviews 2011, Issue 3. [DOI: 10.1002/14651858.CD007781.pub2]

\section{Scottish Government 2017}

Scottish Government. The Scottish independent review of the use, safety and efficacy of transvaginal mesh implants in the treatment of stress urinary incontinence and pelvic organ prolapse in women: final report. Available at: www.gov.scot/ publications/scottish-independent-review-use-safety-efficacytransvaginal-mesh-implants-treatment-9781786528711/. Edinburgh: The Scottish Government, (accessed prior to 14 November 2019).

\section{Shemilt 2019}

Shemilt I, Aluko P, Graybill E, Craig D, Henderson C, Drummond M, Wilson ECF, Robalino S, Vale L, on behalf of the Campbell and Cochrane Economics Methods Group. Chapter 20: Economic evidence. In: Higgins JPT, Thomas J, Chandler J, Cumpston M, Li T, Page MJ, Welch VA (editors). Cochrane Handbook for Systematic Reviews of Interventions version 6.0 (updated July 2019). Cochrane, 2019. Available from www.training.cochrane.org/handbook.

\section{Shumaker 1994}

Shumaker SA, Wyman JF, Uebersax JS, McClish D, Fantl JA, Continence Program in Women (CPW) Research Group. Healthrelated quality of life measures for women with urinary incontinence: the Incontinence Impact Questionnaire and the Urogenital Distress Inventory. Quality of Life Research 1994;3(5):291-306 


\section{Subak 2008}

Subak LL, Brubaker L, Chai TC, Creasman JM, Diokno AC, Goode PS, et al. High costs of urinary incontinence among women electing surgery to treat stress incontinence. Obstetrics and Gynecology 2008;111(4):899-907. [NCT00064662; srincont27122]

\section{Thakar 2000}

Thakar R, Stanton S. Regular review: management of urinary incontinence in women. BMJ 2000;321(7272):1326-31.

\section{Valpas 2006}

Valpas A, Rissanen P, Kujansuu E, Nilsson CG. A costeffectiveness analysis of tension-free vaginal tape versus laparoscopic mesh colposuspension for primary female stress incontinence. Acta Obstetricia et Gynecologica Scandinavica 2006;85(12):1485-90. [sr-incont22539]

\section{Vancaillie 1991}

Vancaillie TG, Schuessler W. Laparoscopic bladderneck suspension. Journal of Laparoendoscopic Surgery 1991;1(3):169-73.

\section{Wagner 1998}

Wagner TH, Hu TW. Economic costs of urinary incontinence in 1995. Urology 1998;51(3):355-61. [sr-incont16942]

\section{Ware 1993}

Ware JE, Snow KK, Kosinski M, Gandek B. SF-36 Health Survey Manual and Interpretation Guide. Boston, MA: The Health Institute, New England Medical Centre, 1993.

\section{Wilson 1996}

Wilson PD, Herbison RM, Herbison GP. Obstetric practice and the prevalence of urinary incontinence three months after delivery. British Journal of Obstetrics and Gynaecology 1996;103(2):154-61.

\section{References to other published versions of this review \\ Dean 2006}

Dean N, Ellis G, Herbison GP, Wilson D. Laparoscopic colposuspension for urinary incontinence in women. Cochrane Database of Systematic Reviews 2006, Issue 3. [DOI: 10.1002/14651858.CD002239.pub2]

\section{Dean 2017}

Dean N, Ellis G, Herbison GP, Wilson D, Mashayekhi A. Laparoscopic colposuspension for urinary incontinence in women. Cochrane Database of Systematic Reviews 2017, Issue 7. [DOI: 10.1002/14651858.CD002239.pub3]

\section{Moehrer 2000}

Moehrer B, Ellis G, Carey M, Wilson PD. Laparoscopic colposuspension for urinary incontinence in women. Cochrane Database of Systematic Reviews 2000, Issue 3. [DOI: 10.1002/14651858.CD002239]

\section{Wilson 2000}

Wilson PD, Carey M, Burton G. Laparoscopic surgery (retropubic suspension) for urinary incontinence in women. Cochrane Database of Systematic Reviews 2000, Issue 3. [DOI: 10.1002/14651858.CD002239]

* Indicates the major publication for the study

\section{CHARACTERISTICS OF STUDIES}

Characteristics of included studies [ordered by study ID]

Adile 2001

\begin{tabular}{ll}
\hline Methods & Design: RCT \\
\hline Participants & 133 women \\
& Mean ages: Group I = 51; Group II = 52 \\
& Postmenopausal: Group I = 57.5\%; Group II = 28.3\% \\
& All had urodynamics, Q tip test, vaginal profile, pad test \\
& All participants showed USI \\
& Participants that needed additional surgical procedures and those who had previous continence \\
& surgery were excluded. \\
& Group I ( $n=66$ ): LC \\
& Group II ( $n=67):$ TVT \\
& Surgeons had 6 months' training for LC and 15 days for the TVT; GA for LC and regional or LA for TVT.
\end{tabular}


Adile 2001 (Continued)

Both groups had Foley catheters and these were removed 3-4 $\mathrm{h}$ after the procedure.

Outcomes Duration of surgery, blood loss, haematomas, bladder perforations, duration of hospitalisation, subjective/objective cure rate at 6-36 months; de novo bladder overactivity

Adverse effects: 3 bladder injuries in TVT group; 2 haematomas in LC group

Notes

Unclear regarding method of randomisation

Follow-up: 3-36 months

This trial is a conference abstract with little detail reported.

\section{Risk of bias}

\begin{tabular}{|c|c|c|}
\hline Bias & Authors' judgement & Support for judgement \\
\hline $\begin{array}{l}\text { Random sequence genera- } \\
\text { tion (selection bias) }\end{array}$ & Unclear risk & Quote: "Randomised" \\
\hline $\begin{array}{l}\text { Allocation concealment } \\
\text { (selection bias) }\end{array}$ & Unclear risk & Quote: "Randomised" \\
\hline $\begin{array}{l}\text { Blinding of participants } \\
\text { and personnel (perfor- } \\
\text { mance bias) } \\
\text { All outcomes }\end{array}$ & Unclear risk & Not possible \\
\hline $\begin{array}{l}\text { Blinding of outcome as- } \\
\text { sessment (detection bias) } \\
\text { All outcomes }\end{array}$ & Unclear risk & No information \\
\hline $\begin{array}{l}\text { Incomplete outcome data } \\
\text { (attrition bias) } \\
\text { All outcomes }\end{array}$ & Unclear risk & No information \\
\hline $\begin{array}{l}\text { Selective reporting (re- } \\
\text { porting bias) }\end{array}$ & Unclear risk & No information \\
\hline Other bias & Unclear risk & This trial is a conference abstract with little detail reported \\
\hline
\end{tabular}

Ankardal 2004

\begin{tabular}{ll}
\hline Methods & Design: RCT \\
\hline Participants & Setting: 4 hospitals \\
& Country: Sweden \\
& 240 women randomised (Group I = 120; Group II = 120) \\
& All women referred with USI as their main symptom \\
& Patient characteristics similar in each group \\
\hline Interventions & Group I ( $n=109):$ LC \\
Group II $(n=98):$ OC
\end{tabular}


Ankardal 2004 (Continued)

Total of 7 surgeons. Most had performed $>60$ LCs before and supervised 2 others starting the technique. The LC was performed by the transperitoneal approach using mesh and staples. 2 non-absorbable sutures each side were used in the OC. The laparoscopic group had a urethral catheter inserted at the end of the procedure and the open group had a suprapubic catheter.

Outcomes Subjective cure and objective cure $(<8 \mathrm{~g} / 24 \mathrm{~h}$ on a 48 -h pad test, and leakage on a frequency/volume chart). VAS used to assess subjective improvement and QoL. Duration of surgery, blood loss, duration of catheter drainage, duration of hospital stay, complications (bladder perforation haematoma leading to re-operation, UTI within 1 month, wound infection and urinary retention $>5$ days).

Of the laparoscopic Group I, 5 were converted to open procedures.

Notes Withdrawals before surgery: Group I = $11(n=109)$; Group II = $22(n=98)$

Power calculation

Only analysed those that were operated on as they still had enough power, but this may be biased

Follow-up: 1 year

\section{Risk of bias}

\begin{tabular}{lll}
\hline Bias & Authors' judgement & Support for judgement \\
\hline $\begin{array}{l}\text { Random sequence genera- } \\
\text { tion (selection bias) }\end{array}$ & Unclear risk & Quote: "Patients were randomly allocated" \\
\hline $\begin{array}{l}\text { Allocation concealment } \\
\text { (selection bias) }\end{array}$ & Low risk & $\begin{array}{l}\text { Quote: "Opaque sealed envelopes were distributed to the different centres be- } \\
\text { fore starting the randomisation." }\end{array}$ \\
\hline $\begin{array}{l}\text { Blinding of participants } \\
\text { and personnel (perfor- } \\
\text { mance bias) }\end{array}$ & Unclear risk & $\begin{array}{l}\text { Blinding of participants not possible. Quote: "No attempt to mask the type of } \\
\text { procedure to the staff at the ward was made." }\end{array}$ \\
\hline
\end{tabular}

\begin{tabular}{ll}
\hline Blinding of outcome as- & Unclear risk \\
sessment (detection bias) & \\
All outcomes & \\
\hline
\end{tabular}

Incomplete outcome data Low risk No differential dropout. Adequate explanation for dropouts

(attrition bias)

All outcomes

\begin{tabular}{lll}
\hline $\begin{array}{l}\text { Selective reporting (re- } \\
\text { porting bias) }\end{array}$ & Low risk & All outcomes in methods reported in full in results \\
\hline Other bias & Low risk & No other source of potential bias identified \\
\hline
\end{tabular}

\section{Ankardal 2005}

\begin{tabular}{ll}
\hline Methods & Design: 3-arm RCT \\
& Follow-up: 1 year \\
\hline Participants & Setting: 4 hospitals \\
& Country: Sweden
\end{tabular}


Ankardal 2005 (Continued)

211 women randomised

All women referred with USI as their main symptom

Participant characteristics similar in each group

\begin{tabular}{ll}
\hline Interventions & Group I $(\mathrm{n}=79)$ : OC using sutures \\
& Group II ( $\mathrm{n}=53)$ : LC using sutures \\
Group III $(\mathrm{n}=79)$ : LC using mesh \\
\hline Outcomes & $\begin{array}{l}\text { Subjective cure and objective cure }(<8 \mathrm{~g} / 24 \mathrm{~h} \text { on a 48- } \mathrm{h} \text { pad test, and leakage on a frequency/volume } \\
\text { chart). VAS used to assess subjective improvement and QoL. Duration of surgery, blood loss, duration } \\
\text { of catheter drainage, duration of hospital stay, complications (bladder perforation, haematoma leading } \\
\text { to re-operation, UTI within } 1 \text { month, wound infection and urinary retention }>5 \text { days) }\end{array}$
\end{tabular}

\begin{tabular}{ll}
\hline Notes & $\begin{array}{l}\text { Withdrawals before surgery: Group I }(n=16) \text {, Group II }(n=4), \text { Group III }(n=4) \text { due to failure to meet all } \\
\text { inclusion criteria or regret decision after randomisation }\end{array}$ \\
Power calculation \\
Follow-up: 1 year
\end{tabular}

\section{Risk of bias}

\begin{tabular}{|c|c|c|}
\hline Bias & Authors' judgement & Support for judgement \\
\hline $\begin{array}{l}\text { Random sequence genera- } \\
\text { tion (selection bias) }\end{array}$ & Unclear risk & Quote: "randomly allocated" \\
\hline $\begin{array}{l}\text { Allocation concealment } \\
\text { (selection bias) }\end{array}$ & Low risk & Quote: "opaque sealed envelopes were used in the randomization process" \\
\hline $\begin{array}{l}\text { Blinding of participants } \\
\text { and personnel (perfor- } \\
\text { mance bias) } \\
\text { All outcomes }\end{array}$ & Unclear risk & $\begin{array}{l}\text { Blinding of participants not possible. Quote: "No attempt to mask the type of } \\
\text { procedure to the staff at the ward was made." }\end{array}$ \\
\hline $\begin{array}{l}\text { Blinding of outcome as- } \\
\text { sessment (detection bias) } \\
\text { All outcomes }\end{array}$ & Unclear risk & Not reported \\
\hline $\begin{array}{l}\text { Incomplete outcome data } \\
\text { (attrition bias) } \\
\text { All outcomes }\end{array}$ & Low risk & No differential dropout. Adequate explanations for dropouts \\
\hline $\begin{array}{l}\text { Selective reporting (re- } \\
\text { porting bias) }\end{array}$ & Low risk & Outcomes reported in full \\
\hline Other bias & Low risk & No other source of potential bias identified \\
\hline
\end{tabular}

Burton 1997

\begin{tabular}{ll}
\hline Methods & Design: RCT \\
\hline Participants & $\begin{array}{l}60 \text { women } \\
\text { Inclusion criteria: age } \geq 30, \text { moderate to severe urodynamically proven USI }\end{array}$ \\
\hline
\end{tabular}


Burton 1997 (Continued)

Exclusion criteria: previous bladder neck surgery, previous major abdominal surgery, hysterectomy, > 1st degree prolapse, diabetes, CNS condition severe COAD, steroid dependent asthma, recurrent UTI, MUCP $<25 \mathrm{~cm} \mathrm{H}_{2} \mathrm{O}$

\begin{tabular}{ll}
\hline Interventions & Group I $(n=30):$ LC \\
& Group II $(n=30):$ OC \\
& 15 previous LCs to familiarise and standardise technique, transperitoneal approach for LC, same sur- \\
& geon for all operations, Dexon suture used in both groups, suprapubic catheter
\end{tabular}

Outcomes Duration of surgery, blood loss, catheterisation time, duration of hospital stay, analgesia use, adverse events, videocystourethrography, urodynamics, residuals, voiding difficulties, 1-h pad test, urinary diary, visual analogue symptoms score

Adverse events: Group I: 1 bladder perforation, 1 UTI; Group II: 1 bladder perforation, 1 voiding difficul-
ties, 1 wound infection
3 women in Group I had repeat surgery (3 OCs)
Power calculation
Follow-up: 6 months, 1 year, 3 years and 5 years
Losses to follow-up: none at 6/12
Group I: 7 ( 3 at 1 year, 5 at 3 years, 7 at 5 years)
Group II: 6 ( 2 at 1 year, 5 at 3 years, 6 at 5 years)
This trial is a conference abstract with little detail reported

\section{Risk of bias}

\begin{tabular}{lll}
\hline Bias & Authors' judgement & Support for judgement \\
\hline $\begin{array}{l}\text { Random sequence genera- } \\
\text { tion (selection bias) }\end{array}$ & Unclear risk & $\begin{array}{l}\text { Quote: "Sixty women with urodynamically proven GSI were randomised to } \\
\text { open and laparoscopic colposuspension" }\end{array}$ \\
\hline $\begin{array}{l}\text { Allocation concealment } \\
\text { (selection bias) }\end{array}$ & Unclear risk & Not reported \\
\hline $\begin{array}{l}\text { Blinding of participants } \\
\text { and personnel (perfor- } \\
\text { mance bias) } \\
\text { All outcomes }\end{array}$ & Unclear risk & Not possible \\
\hline $\begin{array}{l}\text { Blinding of outcome as- } \\
\text { sessment (detection bias) }\end{array}$ & Unclear risk & Not reported \\
$\begin{array}{l}\text { All outcomes } \\
\begin{array}{l}\text { Incomplete outcome data } \\
\text { (attrition bias) } \\
\text { All outcomes }\end{array}\end{array}$ & Unclear risk & Not reported \\
\hline $\begin{array}{l}\text { Selective reporting (re- } \\
\text { porting bias) }\end{array}$ & Low risk & All outcomes in methods reported in results \\
\hline \begin{tabular}{l} 
Other bias \\
\hline
\end{tabular} & Unclear risk & This trial is a conference abstract with little detail reported \\
\hline
\end{tabular}


Carey 2006

Methods

Design: RCT comparing laparoscopic with OC, power calculation on non-patient-orientated outcomes only

\section{Risk of bias}

\begin{tabular}{|c|c|c|}
\hline Bias & Authors' judgement & Support for judgement \\
\hline $\begin{array}{l}\text { Random sequence genera- } \\
\text { tion (selection bias) }\end{array}$ & Low risk & $\begin{array}{l}\text { Quote: "Randomisation lists were computer generated with a block of size of } \\
\text { six, stratified for each centre and for women undergoing concomitant recto- } \\
\text { cele repair for symptomatic rectocele." }\end{array}$ \\
\hline $\begin{array}{l}\text { Allocation concealment } \\
\text { (selection bias) }\end{array}$ & Low risk & $\begin{array}{l}\text { Quote: "Subjects were randomised the day before surgery. Lists were held by } \\
\text { the nonsurgical investigator. The surgeons and operating theatre staff were in- } \\
\text { formed of the treatment group immediately prior to surgery" }\end{array}$ \\
\hline $\begin{array}{l}\text { Blinding of participants } \\
\text { and personnel (perfor- } \\
\text { mance bias) } \\
\text { All outcomes }\end{array}$ & Low risk & $\begin{array}{l}\text { Quote: "Identical iodine-soaked dressings were applied to all subjects in an at- } \\
\text { tempt to blind both patients and postoperative nursing staff to the procedure } \\
\text { performed. The mode of surgery was not documented on the postoperative } \\
\text { record." }\end{array}$ \\
\hline $\begin{array}{l}\text { Blinding of outcome as- } \\
\text { sessment (detection bias) } \\
\text { All outcomes }\end{array}$ & Unclear risk & Not reported \\
\hline $\begin{array}{l}\text { Incomplete outcome data } \\
\text { (attrition bias) } \\
\text { All outcomes }\end{array}$ & Low risk & No differential dropout. Adequate explanation for dropouts \\
\hline $\begin{array}{l}\text { Selective reporting (re- } \\
\text { porting bias) }\end{array}$ & Low risk & Outcomes reported in full \\
\hline Other bias & Low risk & No other source of potential bias identified \\
\hline
\end{tabular}


Cheon 2003

\begin{tabular}{|c|c|}
\hline Methods & Design: RCT comparing LC with OC \\
\hline Participants & $\begin{array}{l}90 \text { women with urodynamically proven SUI } \\
\text { Excluded women who had undergone previous anti-continence surgery or ISD } \\
13(30.2 \%) \text { of Group I and } 7(14.9 \%) \text { of Group II had MUI (SUI and UUI) }\end{array}$ \\
\hline Interventions & $\begin{array}{l}\text { Group I ( } \mathrm{n}=43) \text { : OC } \\
\text { Group II }(\mathrm{n}=47) \text { : LC } \\
16(37.2 \%) \text { of Group I and } 7(14.9 \%) \text { of Group II had concomitant hysterectomy } \\
\text { Laparoscopic approaches were both transperitoneal and extraperitoneal; both open and laparoscopic } \\
\text { procedures used } 2 \text { sutures (Ethibond) } \\
2 \text { surgeons had performed > } 15 \text { LCs before starting the trial. }\end{array}$ \\
\hline Outcomes & $\begin{array}{l}\text { Subjective cure and improvement, objective urodynamic testing, duration of operation (colposuspen- } \\
\text { sion only), EBL, duration of bladder training, length of in-patient stay, time to return to normal activi- } \\
\text { ties, days leave taken, complications and change in severity of incontinence (1-h pad test) }\end{array}$ \\
\hline Notes & $\begin{array}{l}\text { Total perioperative complications: Group I = 15; Group II = } 11 \\
\text { Bladder perforations: } 2 \text { in laparoscopic group and } 0 \text { in OC group } \\
1 \text { woman in Group I converted to open procedure } \\
\text { Follow-up: } 1 \text { year }\end{array}$ \\
\hline
\end{tabular}

\section{Risk of bias}

\begin{tabular}{|c|c|c|}
\hline Bias & Authors' judgement & Support for judgement \\
\hline $\begin{array}{l}\text { Random sequence genera- } \\
\text { tion (selection bias) }\end{array}$ & Low risk & $\begin{array}{l}\text { Quote: "Patients were randomised according to a computer-generated ran- } \\
\text { dom number table." }\end{array}$ \\
\hline $\begin{array}{l}\text { Allocation concealment } \\
\text { (selection bias) }\end{array}$ & Low risk & $\begin{array}{l}\text { Quote: "Each patient was assigned by opening the next sequentially num- } \\
\text { bered, sealed, opaque envelope." }\end{array}$ \\
\hline $\begin{array}{l}\text { Blinding of participants } \\
\text { and personnel (perfor- } \\
\text { mance bias) } \\
\text { All outcomes }\end{array}$ & Unclear risk & Not possible \\
\hline $\begin{array}{l}\text { Blinding of outcome as- } \\
\text { sessment (detection bias) } \\
\text { All outcomes }\end{array}$ & Unclear risk & Not reported \\
\hline $\begin{array}{l}\text { Incomplete outcome data } \\
\text { (attrition bias) } \\
\text { All outcomes }\end{array}$ & Low risk & No withdrawals reported. All randomised participants included in analysis \\
\hline $\begin{array}{l}\text { Selective reporting (re- } \\
\text { porting bias) }\end{array}$ & Low risk & Outcomes reported in full \\
\hline Other bias & Low risk & No other source of potential bias identified \\
\hline
\end{tabular}


Fatthy 2001

\begin{tabular}{|c|c|}
\hline Methods & Design: RCT \\
\hline Participants & $\begin{array}{l}74 \text { women } \\
\text { Inclusion criteria: urodynamically diagnosed USI } \\
\text { Exclusion criteria: DI, underactive detrusor, ISD, limited vaginal mobility, stage III and IV vaginal pro- } \\
\text { lapse, contraindications to laparoscopy and surgery in general }\end{array}$ \\
\hline Interventions & $\begin{array}{l}\text { Group I }(n=34): \text { LC } \\
\text { Group II }(n=40) \text { : OC } \\
\text { Extraperitoneal approach, number } 1 \text { non-absorbable polypropylene suture, } 1 \text { suture on each side of } \\
\text { urethrovesical junction, } 1 \text { st surgeon performed } 23 \text { and } 2 \text { nd surgeon } 16 \text { laparoscopic procedures before } \\
\text { starting the trial, prophylactic cephradine } 1 \mathrm{~g} 3 \text { times/day for } 24 \mathrm{~h}\end{array}$ \\
\hline & $\begin{array}{l}\text { Catheterisation Group I: Foley for } 24 \mathrm{~h} \text {, removed if postvoid volume }<100 \mathrm{~mL} \text {; Group II: Bonnano supra- } \\
\text { pubic catheter for } 48 \mathrm{~h} \text {, removed if postvoid volume }<100 \mathrm{~mL}\end{array}$ \\
\hline
\end{tabular}

Outcomes

$24 \mathrm{~h}$ urinary diary, urodynamics at 6 and 18 months by independent urologist who was blinded to procedure performed, assessment of subjective success by questionnaire about urinary leakage, lack of need to wear pads at rest and at different activity levels, comparison of pre- and postoperative symptoms, objective success assessed through cough provocation test, Valsalva leak point pressure, MUCP, maximum urethral pressure, operating time, EBL, analgesia use (immediate postoperative pain), voiding difficulties, hospital stay, time to return to light work, pelvic relaxation (post-op rectocele), dyspareunia

Definition of cure: subjective cure $=$ dry - completely continent or only rarely requiring pad with exertion with which the woman was completely satisfied; objective cure = negative cough stress test and urodynamically confirmed absence of leakage during Valsalva manoeuvre and repeated coughing, as well as a significant improvement in MUCP

Definition of failure: subjective = change in amount of leakage with which woman was not satisfied; objective $=$ postoperative de novo $\mathrm{DI}$

Notes

Adverse effects: Group I: 1 bladder injury, 1 bladder perforation, 4 dysuria, 2 voiding difficulties; Group II: 1 bladder injury, 2 superficial wound infections, 1 retropubic haematoma, 2 dysuria, 2 voiding difficulties

Follow-up: 4 weeks postoperatively and every 6 months up to 18 months

Losses to follow-up: 1 in Group II

15 menopausal women were not receiving HRT (8 in Group I, 7 in Group II); they were prescribed HRT for $3 / 12$ before their scheduled surgery.

6 participants in Group I and 9 participants in Group II had additional rectocele repair

\section{Risk of bias}

\begin{tabular}{lll}
\hline Bias & Authors' judgement & Support for judgement \\
\hline $\begin{array}{l}\text { Random sequence genera- } \\
\text { tion (selection bias) }\end{array}$ & Low risk & $\begin{array}{l}\text { Quote: "Randomization was done using random number table balanced ran- } \\
\text { domization with blinding and disguised block length. This method ensured } \\
\text { that the number of patients allocated to each group was approximately equal } \\
\text { during the entire study." }\end{array}$ \\
\hline $\begin{array}{l}\text { Allocation concealment } \\
\text { (selection bias) }\end{array}$ & Low risk & $\begin{array}{l}\text { Quote: "The statistician did not allow surgeons or patients to know which type } \\
\text { of operation was next." }\end{array}$ \\
\hline $\begin{array}{l}\text { Blinding of participants } \\
\begin{array}{l}\text { and personnel (perfor- } \\
\text { mance bias) } \\
\text { All outcomes }\end{array}\end{array}$ & Unclear risk & Not possible \\
\hline
\end{tabular}


Fatthy 2001 (Continued)
Blinding of outcome as-
Unclear risk
Not reported sessment (detection bias)

All outcomes

\begin{tabular}{lll}
\hline $\begin{array}{l}\text { Incomplete outcome data } \\
\text { (attrition bias) } \\
\text { All outcomes }\end{array}$ & Low risk & No differential dropout. All randomised participants included in analysis \\
\hline $\begin{array}{l}\text { Selective reporting (re- } \\
\text { porting bias) }\end{array}$ & Low risk & Outcomes reported in full \\
\hline Other bias & Low risk & No other source of potential bias identified \\
\hline
\end{tabular}

Foote 2006

\begin{tabular}{ll}
\hline Methods & Design: RCT \\
\hline Participants & $\begin{array}{l}\text { Exclusion criteria: other diagnosis such as DO or voiding difficulty, previous retropubic surgery, weight } \\
>100 \mathrm{~kg}, \text { significant prolapse, required other gynaecological surgery or were unsuitable for laparoscop- } \\
\text { ic surgery }\end{array}$ \\
\hline Interventions & $\begin{array}{l}\text { Group I }(\mathrm{n}=40): \text { LC } \\
\text { Group II ( } \mathrm{n}=40): \text { vaginal mesh sling 'SPARC' } \\
\text { 1 surgeon performed all the operations. }\end{array}$ \\
\hline Outcomes & Urodynamics, bladder diary, VAS score, QoL (York and UDI) at 6 months. Intraoperative complications \\
\hline Notes & $\begin{array}{l}\text { Adverse effects: } 1 \text { bladder suturing requiring intraoperative repositioning, } 3 \text { needle perforations of the } \\
\text { bladder requiring repositioning, } 1 \text { mesh erosion, } 1 \text { with voiding difficulty in mesh group } \\
\text { Follow-up: } 6 \text { months }\end{array}$
\end{tabular}

\section{Risk of bias}

\begin{tabular}{|c|c|c|}
\hline Bias & Authors' judgement & Support for judgement \\
\hline $\begin{array}{l}\text { Random sequence genera- } \\
\text { tion (selection bias) }\end{array}$ & Low risk & $\begin{array}{l}\text { Quote: "Randomisation was performed by a computer-generated list with allo- } \\
\text { cation at the time of surgical consent." }\end{array}$ \\
\hline $\begin{array}{l}\text { Allocation concealment } \\
\text { (selection bias) }\end{array}$ & Unclear risk & Not reported \\
\hline $\begin{array}{l}\text { Blinding of participants } \\
\text { and personnel (perfor- } \\
\text { mance bias) } \\
\text { All outcomes }\end{array}$ & Unclear risk & Not possible \\
\hline $\begin{array}{l}\text { Blinding of outcome as- } \\
\text { sessment (detection bias) } \\
\text { All outcomes }\end{array}$ & Unclear risk & Not reported \\
\hline
\end{tabular}

Incomplete outcome data Low risk $\quad$ No differential dropout
(attrition bias)


Foote 2006 (Continued)

All outcomes

Selective reporting (re- Low risk $\quad$ Outcomes reported in full
porting bias)

Other bias Low risk No other source of potential bias identified

\section{Kitchener 2006}

$\begin{array}{ll}\text { Methods } & \text { Design: RCT } \\ & \text { Dates of recruitment: April 1999-February } 2002\end{array}$

\begin{tabular}{|c|c|}
\hline \multirow[t]{3}{*}{ Participants } & Setting: 6 units \\
\hline & Country: UK \\
\hline & 291 women with urodynamically proven SUI \\
\hline \multirow[t]{2}{*}{ Interventions } & $\begin{array}{l}\text { Group I }(n=144) \text { : LC using } 2 \text { Ethibond sutures each side } \\
\text { Group II }(n=147) \text { : OC }\end{array}$ \\
\hline & $\begin{array}{l}\text { Both groups were treated with the standard surgical procedure of antibiotic prophylax } \\
\text { tion, suprapubic catheterisation and patient-controlled analgesia postoperatively. }\end{array}$ \\
\hline Outcomes & $\begin{array}{l}\text { Primary outcomes: subjective question of satisfaction with outcome, objective negativ } \\
\text { Secondary outcomes: levels of operative morbidity, time to return to work }\end{array}$ \\
\hline \multirow[t]{3}{*}{ Notes } & $88 \%$ subjective data available at 2 years and $82.5 \%$ objective data available at 2 years \\
\hline & ITT and power calculation performed \\
\hline & Follow-up: 6 weeks, 6 months, 12 months and 24 months \\
\hline
\end{tabular}

\section{Risk of bias}

\begin{tabular}{|c|c|c|}
\hline Bias & Authors' judgement & Support for judgement \\
\hline $\begin{array}{l}\text { Random sequence genera- } \\
\text { tion (selection bias) }\end{array}$ & Low risk & $\begin{array}{l}\text { Quote: "Randomisation was performed by telephone at the University of York } \\
\text { using random number permuted block sizes } 2 \text { and } 4 \text { with a dispersed block } \\
\text { throughout the string, stratified by centre, age }>50 \text { years and previous bladder } \\
\text { neck surgery." }\end{array}$ \\
\hline $\begin{array}{l}\text { Allocation concealment } \\
\text { (selection bias) }\end{array}$ & Unclear risk & Not reported \\
\hline $\begin{array}{l}\text { Blinding of participants } \\
\text { and personnel (perfor- } \\
\text { mance bias) } \\
\text { All outcomes }\end{array}$ & Unclear risk & $\begin{array}{l}\text { Quote: "There was no attempt to blind the surgical procedure as this was con- } \\
\text { sidered neither practical nor pragmatic." }\end{array}$ \\
\hline $\begin{array}{l}\text { Blinding of outcome as- } \\
\text { sessment (detection bias) } \\
\text { All outcomes }\end{array}$ & Unclear risk & Not reported \\
\hline
\end{tabular}

Incomplete outcome data Low risk No differential dropout. Adequate explanation for dropouts (attrition bias) 
Kitchener 2006 (Continued)

All outcomes

Selective reporting (re- Low risk Outcomes reported in full
porting bias)

Other bias Low risk No other source of potential bias identified

Maher 2004

\begin{tabular}{|c|c|}
\hline Methods & Design: RCT \\
\hline \multirow[t]{4}{*}{ Participants } & 82 women with recurrent SUI and or ISD $\left(\mathrm{MUCP} \leq 20 \mathrm{H}_{2} \mathrm{O}\right)$ \\
\hline & Participants all had recurrent SUI \\
\hline & Previous continence surgery: Group I = 61\%; Group II = 65\% \\
\hline & $\begin{array}{l}\text { Exclusion criteria: women primarily presenting with pelvic organ prolapse, rigid urethra, those unfit for } \\
\text { GA }\end{array}$ \\
\hline Interventions & $\begin{array}{l}\text { Group I }(n=40): \text { TVT } \\
\text { Group II }(n=42): \text { LC }\end{array}$ \\
\hline \multirow[t]{3}{*}{ Outcomes } & $\begin{array}{l}\text { Subjective cure, de novo DO, voiding problems, QoL scores (change in SUDI, SIIQ, SF-36), satisfaction } \\
\text { score, length of inpatient stay, time to return to normal activities, operation time, duration of catheter } \\
\text { postoperatively, blood loss, postoperative increase in MUCP }\end{array}$ \\
\hline & $\begin{array}{l}\text { In the TVT group A, } 1 \text { woman had to be converted to } \mathrm{OC} \text { and another woman had an incidental finding } \\
\text { of grade } 1 \text { transitional cell carcinoma. }\end{array}$ \\
\hline & In the laparoscopic arm B, 9 underwent open procedures due to $\mathrm{BMI}>35$. \\
\hline \multirow[t]{6}{*}{ Notes } & $\begin{array}{l}\text { In Group I, } 1 \text { woman had to be converted to } O C \text { and another woman had an incidental finding of grade } \\
1 \text { transitional cell carcinoma. }\end{array}$ \\
\hline & In Group II, 9 underwent open procedures due to BMI > 35 \\
\hline & Power calculation was done. \\
\hline & Performed ITT analysis \\
\hline & Follow-up: 6 weeks and 6 months \\
\hline & This trial is a conference abstract with little detail reported \\
\hline
\end{tabular}

\section{Risk of bias}

\begin{tabular}{lll}
\hline Bias & Authors' judgement & Support for judgement \\
\hline $\begin{array}{l}\text { Random sequence genera- } \\
\text { tion (selection bias) }\end{array}$ & Low risk & $\begin{array}{l}\text { Quote: "A computer generated randomisation list was held by the non-surgical } \\
\text { coauthor." }\end{array}$ \\
\hline $\begin{array}{l}\text { Allocation concealment } \\
\text { (selection bias) }\end{array}$ & Unclear risk & Not reported \\
\hline $\begin{array}{l}\text { Blinding of participants } \\
\text { and personnel (perfor- } \\
\text { mance bias) }\end{array}$ & Unclear risk & Not possible \\
\hline
\end{tabular}


Maher 2004 (Continued)

All outcomes

Blinding of outcome as-
sessment (detection bias) $\quad$ Unclear risk $\quad$ Not reported

sessment (detection bias)

All outcomes

Incomplete outcome data Low risk No differential dropout
(attrition bias)

All outcomes

Selective reporting (re- Low risk Outcomes reported in full
porting bias)

porting bias)

\begin{tabular}{|c|c|c|}
\hline Other bias & Unclear risk & This trial is a conference abstract with little detail reported \\
\hline
\end{tabular}

Mirosh 2005

\begin{tabular}{|c|c|}
\hline Methods & Design: RCT \\
\hline \multirow[t]{3}{*}{ Participants } & 30 women with urodynamic SUI \\
\hline & $\begin{array}{l}\text { Participants were at least } 30 \text { years old and had no previous incontinence surgery, had no need for con- } \\
\text { current surgery }\end{array}$ \\
\hline & Exclusion criteria: included grade 3 to 4 pelvic organ prolapse, MUI \\
\hline \multirow[t]{3}{*}{ Interventions } & Group I $(n=16):$ TVT \\
\hline & Group II $(n=14):$ LC \\
\hline & $\begin{array}{l}\text { TVT operations were performed under spinal anaesthetic; LC was performed under GA. All were per- } \\
\text { formed by a single surgeon. }\end{array}$ \\
\hline
\end{tabular}

\begin{tabular}{ll}
\hline Outcomes & Primary outcomes: anaesthetic, operation, and hospital stay times \\
Secondary outcomes: patient satisfaction, QoL scores, complications \\
Postoperative complications TVT = 1 urinary retention that needed the tape loosening, \\
LC = 1 right-sided ureteric obstruction and needed the right-sided sutures removing \\
\hline Notes & $\begin{array}{l}\text { Postoperative complications: Group I = } 1 \text { urinary retention that needed the tape loosening; Group II = } 1 \\
\text { right-sided ureteric obstruction and needed the right-sided sutures removing } \\
\text { This trial is a conference abstract with little detail reported }\end{array}$
\end{tabular}

\section{Risk of bias}

\begin{tabular}{lll}
\hline Bias & Authors' judgement & Support for judgement \\
\hline $\begin{array}{l}\text { Random sequence genera- } \\
\text { tion (selection bias) }\end{array}$ & Unclear risk & Not reported \\
\hline $\begin{array}{l}\text { Allocation concealment } \\
\text { (selection bias) }\end{array}$ & Unclear risk & Not reported \\
\hline $\begin{array}{l}\text { Blinding of participants } \\
\text { and personnel (perfor- } \\
\text { mance bias) }\end{array}$ & Unclear risk & Not possible \\
\end{tabular}


Mirosh 2005 (Continued)

All outcomes

\begin{tabular}{|c|c|c|}
\hline $\begin{array}{l}\text { Blinding of outcome as- } \\
\text { sessment (detection bias) } \\
\text { All outcomes }\end{array}$ & Unclear risk & Not reported \\
\hline $\begin{array}{l}\text { Incomplete outcome data } \\
\text { (attrition bias) } \\
\text { All outcomes }\end{array}$ & Low risk & No dropouts reported \\
\hline $\begin{array}{l}\text { Selective reporting (re- } \\
\text { porting bias) }\end{array}$ & Unclear risk & $\begin{array}{l}\text { Primary outcomes reported in full, secondary outcomes reported without } \\
\text { quantitative data }\end{array}$ \\
\hline Other bias & Unclear risk & This trial is a conference abstract with little detail reported \\
\hline
\end{tabular}

\section{Morris 2001}

\begin{tabular}{|c|c|}
\hline Methods & Design: RCT \\
\hline \multirow[t]{2}{*}{ Participants } & 73 women with urodynamically (cystometry and pad test) proven SUI \\
\hline & DO was not an exclusion criteria. \\
\hline Interventions & $\begin{array}{l}\text { Group I }(n=38) \text { : LC carried out by consultants only } \\
\text { Group II }(n=35): \text { OC carried out by junior medical staff }\end{array}$ \\
\hline Outcomes & $\begin{array}{l}\text { Cystometry repeated at } 2 \text { years and pad test at 5-7 years (median of } 6 \text { years). Objective pad testing, } \\
\text { subjective assessment and de novo DO }\end{array}$ \\
\hline \multirow[t]{5}{*}{ Notes } & Figures based on ITT \\
\hline & Follow-up: 5-7 years \\
\hline & Only 5-7-year follow-up data available \\
\hline & $\begin{array}{l}5 \text { women declined formal review and } 9 \text { were lost to follow-up (resulting in } 30 \text { participants in Group I } \\
\text { and } 29 \text { participants in Group II) }\end{array}$ \\
\hline & This trial is a conference abstract with little detail reported. \\
\hline
\end{tabular}

\section{Risk of bias}

\begin{tabular}{lll}
\hline Bias & Authors' judgement & Support for judgement \\
\hline $\begin{array}{l}\text { Random sequence genera- } \\
\text { tion (selection bias) }\end{array}$ & Unclear risk & Quote: "Randomised to either LC or OC" \\
\hline $\begin{array}{l}\text { Allocation concealment } \\
\text { (selection bias) }\end{array}$ & Unclear risk & Not reported \\
\hline $\begin{array}{l}\text { Blinding of participants } \\
\begin{array}{l}\text { and personnel (perfor- } \\
\text { mance bias) } \\
\text { All outcomes }\end{array}\end{array}$ & Unclear risk & Not possible \\
\hline
\end{tabular}

\begin{tabular}{lll}
\hline Blinding of outcome as- & Unclear risk & Not reported \\
sessment (detection bias)
\end{tabular}


Morris 2001 (Continued)

All outcomes

Incomplete outcome data Low risk N N N differential dropout. Quote: "Figures are based on intention to treat."
(attrition bias)
(attrition bias)

All outcomes

Selective reporting (re- Unclear risk $\quad$ Abstract only - prespecified outcomes unclear
porting bias)

porting bias)

Other bias Unclear risk This trial is a conference abstract with little detail reported.

\section{Paraiso 2004}

\begin{tabular}{|c|c|}
\hline Methods & Design: RCT \\
\hline \multirow[t]{5}{*}{ Participants } & Setting: 2 centres, Cleveland, Ohio \\
\hline & Country: USA \\
\hline & 72 women enrolled \\
\hline & $\begin{array}{l}\text { Inclusion criteria: urodynamic SUI, urethral hypermobility (cotton-tipped swab angle } \geq 30^{\circ} \text { ), ability to } \\
\text { undergo a GA and laparoscopy }\end{array}$ \\
\hline & $\begin{array}{l}\text { Exclusion criteria: previous anti-incontinent surgery, DO on urodynamics, anterior vaginal wall pro- } \\
\text { lapse to or at the hymen }\end{array}$ \\
\hline Interventions & $\begin{array}{l}\text { Group I ( } n=36) \text { : LC, combination of extraperitoneal and transperitoneal approaches used, } 2 \text { sutures of } \\
\text { Ethibond used each side and passed through ipsilateral Cooper's ligament } \\
\text { Group II ( } n=36) \text { : TVT performed under LA with sedation, regional or GA } \\
\text { Both groups had suprapubic catheters postoperatively. Surgeons each with }>80 \text { LC experience. Many } \\
\text { had concurrent surgeries, ranging from bladder biopsy to laparoscopic cholecystectomy. Concurrent } \\
\text { surgery: Group I = } 9(25 \%) \text { had hysterectomy and } 11(32 \%) \text { had adhesiolysis; Group II = } 8(22 \%) \text { had hys- } \\
\text { terectomy and } 4(11 \%) \text { had adhesiolysis. }\end{array}$ \\
\hline
\end{tabular}

Outcomes Primary outcome: objective cure (no leakage on postoperative urodynamics), de novo DO, voiding difficulty and post-void residual. Objective assessment performed at 1 year postoperatively. Subjective assessment, UDI, IIQ, POP-Q, urinary diaries, VAS, all at 1-2 and then 4-8 years postoperatively

Perioperative complications, EBL, change in haematocrit, analgesia requirement, hospital stay, number of days to normal voiding, hospital cost

Notes

Adverse effects: Group I = 2 participants had sutures found in the bladder, which were replaced; 1 participant had a bowel injury, which was repaired at the time of the operation. Group II = 1 participant required intraoperative blood transfusion; 2 bladder perforations.

Postoperative complications included 2 participants in Group II requiring tape-releasing procedures 3 LCs were converted to OCs

Power calculation performed

Follow-up: 1, 2 and 4-8 (long-term) years

3 participants were lost to follow-up from each group. ( $\mathrm{n}=33$ in each group). Further participants lost/ withdrew for the longer term follow-up

$74 \%$ participants completed long-term follow-up at $4-8$ years ( 25 in the TVT group and 28 in the LC group). 
Paraiso 2004 (Continued)

Risk of bias

\begin{tabular}{|c|c|c|}
\hline Bias & Authors' judgement & Support for judgement \\
\hline $\begin{array}{l}\text { Random sequence genera- } \\
\text { tion (selection bias) }\end{array}$ & Low risk & $\begin{array}{l}\text { Quote: "Patients were randomized by a computer-generated randomization } \\
\text { schedule" }\end{array}$ \\
\hline $\begin{array}{l}\text { Allocation concealment } \\
\text { (selection bias) }\end{array}$ & Low risk & $\begin{array}{l}\text { Quote: "allocation to either laparoscopic Burch colposuspension or TVT con- } \\
\text { cealed in a sealed opaque envelope." }\end{array}$ \\
\hline $\begin{array}{l}\text { Blinding of participants } \\
\text { and personnel (perfor- } \\
\text { mance bias) } \\
\text { All outcomes }\end{array}$ & Unclear risk & Not possible \\
\hline $\begin{array}{l}\text { Blinding of outcome as- } \\
\text { sessment (detection bias) } \\
\text { All outcomes }\end{array}$ & Low risk & $\begin{array}{l}\text { Quote: "Interpretation of urodynamic studies } 1 \text { year after surgery was blinded } \\
\text { and performed by the enrolling surgeon and an independent urogynecologist } \\
\text { reviewer." } \\
\text { Comment: objective assessment of cure was blinded. }\end{array}$ \\
\hline $\begin{array}{l}\text { Incomplete outcome data } \\
\text { (attrition bias) } \\
\text { All outcomes }\end{array}$ & Low risk & 72 randomised, 66 analysed. No differential dropout \\
\hline $\begin{array}{l}\text { Selective reporting (re- } \\
\text { porting bias) }\end{array}$ & Low risk & Outcomes reported in full \\
\hline Other bias & Low risk & No other source of potential bias identified \\
\hline
\end{tabular}

\section{Persson 2000}

\begin{tabular}{ll}
\hline Methods & Design: RCT (randomisation 1:1) \\
\hline Participants & 161 women \\
Inclusion criteria: bothersome SUI symptoms, normal urethral closing pressure, hypermobility bladder \\
neck, objective sign of leaking (pad test), SUI with concomitant subdominant urge symptoms without \\
associated urine leakage \\
Exclusion criteria: UUI, SUI due to low urethral closing pressure $\left(<20 \mathrm{~mm} \mathrm{H}_{2} \mathrm{O}\right)$, uterovaginal descent $>$ \\
grade 1 cystocele, incontinence after previous vaginal repair, recurrent incontinence, high risk for $\mathrm{GA}$ or \\
surgical complications
\end{tabular}

Interventions

Group I ( $n=78): 1$ bilateral double-bite Goretex suture

Group II ( $n=83)$ : 2 bilateral single-bite Goretex sutures

Transperitoneal approach, vaginal fascia fixed against Coopers ligament with sutures placed approximately $2 \mathrm{~cm}$ lateral to each side of urethra and $2 \mathrm{~cm}$ distal to bladder neck. Last 84 women received $2 \mathrm{~g}$ Cefoxitin IV at induction. Additional surgery in 63 cases (Group I = 34; Group II = 29). Indwelling catheter, removed within $24 \mathrm{~h}$ postoperatively and residuals recorded, if residual $<125 \mathrm{~mL}$ discharge home, remaining women were offered delayed discharge, discharge with indwelling catheter or discharge with ISC

Outcomes

Main objective outcome variables: leakage on ultrashort pad test, operation time Secondary objective outcome variables: postoperative voiding difficulties, complications during and after surgery, EBL

Objective cure defined as no leaking at ultrashort pad test, improvement max. $1 / 3$ of preoperative leaking volume on pad test, unimproved $>1 / 3$ of preoperative leaking volume on pad test 
Trial set up to enrol 280 participants, trial authors became convinced during follow-up that 2 bilateral sutures have higher cure rate and therefore did an interim analysis on objective 1 year cure rate on 108 participants, which showed a cure rate of $87 \%$ in Group II versus $68 \%$ in Group I. Therefore further enrolment into the trial was stopped and only already enrolled participants were followed-up.

Follow-up: 2 months telephone interview, 1 year clinic visit Losses to follow-up: 1 in Group I, 2 in Group II

9 women refused follow-up pad test

\section{Risk of bias}

\begin{tabular}{lll}
\hline Bias & Authors' judgement & Support for judgement \\
\hline $\begin{array}{l}\text { Random sequence genera- } \\
\text { tion (selection bias) }\end{array}$ & Low risk & $\begin{array}{l}\text { Quote: "An independent research nurse prepared equal numbers of assign- } \\
\text { ments that indicated one or two bilateral sutures. Assignments were put in } \\
\text { opaque envelopes that were sealed, mixed and then numbered." }\end{array}$ \\
\hline $\begin{array}{l}\text { Allocation concealment } \\
\text { (selection bias) }\end{array}$ & Low risk & $\begin{array}{l}\text { Quote: "Just before surgery, the patient was assigned to one of the two study } \\
\text { groups by opening the next consecutively numbered envelope." }\end{array}$ \\
\hline $\begin{array}{l}\text { Blinding of participants } \\
\text { and personnel (perfor- } \\
\text { mance bias) } \\
\begin{array}{l}\text { All outcomes } \\
\end{array}\end{array}$ & Unclear risk & Not reported. Blinding of some personnel not possible \\
\hline
\end{tabular}

\begin{tabular}{lll}
\hline $\begin{array}{l}\text { Blinding of outcome as- } \\
\text { sessment (detection bias) }\end{array}$ & High risk & $\begin{array}{l}\text { Quote: "The same physician who operated on the patients also performed the } \\
\text { follow-up evaluations and interviews without being masked as to the number } \\
\text { of sutures used." }\end{array}$
\end{tabular}

\begin{tabular}{|c|c|c|}
\hline $\begin{array}{l}\text { Incomplete outcome data } \\
\text { (attrition bias) }\end{array}$ & Unclear risk & $\begin{array}{l}\text { Trial stopped early; } 108 \text { women analysed at this point but unclear how many } \\
\text { from each group }\end{array}$ \\
\hline
\end{tabular}

All outcomes

Trial stopped early; 108 women analysed at this point but unclear how many trom

\begin{tabular}{lll}
\hline $\begin{array}{l}\text { Selective reporting (re- } \\
\text { porting bias) }\end{array}$ & Low risk & $\begin{array}{l}\text { All outcomes in Methods reported in Results. Protocol mentioned (not pub- } \\
\text { lished) }\end{array}$ \\
\hline Other bias & Unclear risk & $\begin{array}{l}\text { Trial stopped early because "interim analysis showed a significantly lower cure } \\
\text { rate for women randomized to one suture." }\end{array}$ \\
108 women analysed at this point but unclear how many from each group
\end{tabular}

Persson 2002

\begin{tabular}{ll}
\hline Methods & Design: RCT \\
\hline Participants & Country: Sweden \\
& Approached 270 consecutive women presenting for evaluation of SUI at University Hospital Lund. In \\
& 156 of the women surgical treatment was indicated. \\
& 79 consenting women were randomised. \\
Inclusion criteria: significant SUl proven on urodynamic testing, hypermobility of bladder neck, $>5 \mathrm{~mL}$ \\
on ultrashort pad test, urethral closure $>20 \mathrm{~cm} \mathrm{H}_{2} \mathrm{O}$, urethral functional length $>25 \mathrm{~mm}$
\end{tabular}


Persson 2002 (Continued)

Exclusion criteria: predominant symptom of UUI, previous surgery for prolapse or incontinence, $\geq$ grade 2 prolapse, requiring concurrent gynaecological surgery and all with increased risk for GA and laparoscopic surgery
Group I ( $\mathrm{n}=32)$ : LC, using 2 sutures (polytetrafluoroethylene) each side, GA Group II $(n=38)$ : TVT, LA and sedation

1 surgeon performed all the LCs and 2 surgeons performed the TVTs.

Main outcome measures were subjective change in stress-induced urinary leakage and objective
change in pad test results pre and post operatively.

Notes
2-5 months following surgery, women were telephoned and answered a questionnaire. Any adverse events up to 2 months were noted. Then a 1-year follow-up appointment arranged

\section{Risk of bias}

\begin{tabular}{lll}
\hline Bias & Authors' judgement & Support for judgement \\
\hline $\begin{array}{l}\text { Random sequence genera- } \\
\text { tion (selection bias) }\end{array}$ & Low risk & $\begin{array}{l}\text { Quote: "Randomization was performed as follows: before start of the study, } \\
\text { the research nurse prepared equal numbers of assignments, indicating TV or } \\
\text { laparoscopic colposuspension. She folded the pieces of paper with the assign- } \\
\text { ments several times, mixed them, put them in opaque envelopes that were } \\
\text { sealed, mixed and then numbered." }\end{array}$ \\
\hline
\end{tabular}

\begin{tabular}{ll}
\hline $\begin{array}{l}\text { Allocation concealment } \\
\text { (selection bias) }\end{array}$ & Quote: "Randomization was performed as follows: before start of the study, \\
& $\begin{array}{l}\text { the research nurse prepared equal numbers of assignments, indicating TVT or } \\
\text { laparoscopic colposuspension. She folded the pieces of paper with the assign- } \\
\text { ments several times, mixed them, put them in opaque envelopes that were } \\
\text { sealed, mixed and then numbered." }\end{array}$
\end{tabular}

\begin{tabular}{|c|c|c|}
\hline $\begin{array}{l}\text { Blinding of participants } \\
\text { and personnel (perfor- } \\
\text { mance bias) } \\
\text { All outcomes }\end{array}$ & Unclear risk & Not possible \\
\hline $\begin{array}{l}\text { Blinding of outcome as- } \\
\text { sessment (detection bias) } \\
\text { All outcomes }\end{array}$ & Low risk & $\begin{array}{l}\text { Quote: "The follow-up examination was to be performed by a study nurse } \\
\text { blinded as to which surgical procedure the patients had been operated with. } \\
\text { To achieve blinding, the study nurse was instructed not to read the hospital } \\
\text { chart, to initially tell the patient not to talk about her surgery or any abdominal } \\
\text { scars, and to have the patient keeping a towel over the abdomen during the } \\
\text { examination to cover the scars." }\end{array}$ \\
\hline
\end{tabular}

\begin{tabular}{lll}
\hline $\begin{array}{l}\text { Incomplete outcome data } \\
\text { (attrition bias) } \\
\text { All outcomes }\end{array}$ & Low risk & No differential dropout, loss to follow-up explained adequately \\
\hline $\begin{array}{l}\text { Selective reporting (re- } \\
\text { porting bias) }\end{array}$ & Low risk & $\begin{array}{l}\text { All outcomes in Methods reported in Results. Protocol mentioned (not pub- } \\
\text { lished) }\end{array}$ \\
\hline Other bias & Low risk & No other source of potential bias identified \\
\hline
\end{tabular}

\section{Ross 1996}

\begin{tabular}{ll}
\hline Methods & Design: RCT comparing sutures and mesh in LC; same surgeon for all operations \\
\hline Participants & 69 women; \\
\hline
\end{tabular}


Ross 1996 (Continued)

Inclusion criteria: GSI demonstrated by positive cough stress test with a full bladder, hypermobile ure-

throvesical junction shown by positive Q-Tip and US test + negative CMG;

Exclusion criteria: previous incontinence surgery, DI, inferred ISD

Group I ( $\mathrm{n}=35)$ : LC using sutures (either 0 Ethibond or 0 Gortex)
Group II $(\mathrm{n}=34)$ : LC using polypropylene mesh and staples (disposable "EMS endostapler")
Same transperitoneal approach for both groups, fixation $2 \mathrm{~cm}$ lateral to urethrovesical junction and 2
cm lateral to midurethra, paravaginal fascia to Coopers ligament
Simultaneously treated gynaecological problems in both groups:
Group I: 9 laparoscopic-assisted vaginal hysterectomies, 12 modified McCull culdoplasties, 6 sacro-
colpopexies, 5 posterior repairs
Group II: 11 laparoscopic-assisted vaginal hysterectomies, 17 modified McCull culdoplasties, 4 sacro-
colpopexies, 3 posterior repairs

Outcomes Postoperative: time to void, hospital stay, return to work, complications

At 6/52: cough test with full bladder, if leaking CMG

At 1 year: Q-Tip test, perineal US, cough test with full bladder, if leaking CMG to rule out DI.

Cure defined as negative Q-Tip, US, cough stress test and urodynamics; no subjective findings reported

\section{Notes}

Adverse effects: Group I: 1 haematuria, 2 UTIs, 2 accidental cystotomies; Group II: 2 UTIs, 1 accidental cystotomy, 1 thrombophlebitis, 1 urinary retention

Follow-up: 6 weeks and 1 year

\section{Risk of bias}

\begin{tabular}{|c|c|c|}
\hline Bias & Authors' judgement & Support for judgement \\
\hline $\begin{array}{l}\text { Random sequence genera- } \\
\text { tion (selection bias) }\end{array}$ & Unclear risk & Quote: "Prospectively allocated in randomized fashion to one of two groups." \\
\hline $\begin{array}{l}\text { Allocation concealment } \\
\text { (selection bias) }\end{array}$ & Low risk & $\begin{array}{l}\text { Quote: "The surgical technique was not determined until the morning of the } \\
\text { surgery when the random numbers packet was opened." }\end{array}$ \\
\hline $\begin{array}{l}\text { Blinding of participants } \\
\text { and personnel (perfor- } \\
\text { mance bias) } \\
\text { All outcomes }\end{array}$ & Unclear risk & $\begin{array}{l}\text { Quote: "The same surgeon performed all procedures." } \\
\text { Comment: Blinding of surgeons not possible, blinding of participants and oth- } \\
\text { er personnel not reported }\end{array}$ \\
\hline $\begin{array}{l}\text { Blinding of outcome as- } \\
\text { sessment (detection bias) } \\
\text { All outcomes }\end{array}$ & Unclear risk & Not reported \\
\hline $\begin{array}{l}\text { Incomplete outcome data } \\
\text { (attrition bias) } \\
\text { All outcomes }\end{array}$ & Low risk & $\begin{array}{l}\text { All randomised participants included in analysis. Quote: "Procedures were per- } \\
\text { formed in } 69 \text { women, all of whom were available for follow-up in the first year." }\end{array}$ \\
\hline $\begin{array}{l}\text { Selective reporting (re- } \\
\text { porting bias) }\end{array}$ & Low risk & All outcomes in Methods reported in full in Results \\
\hline Other bias & Low risk & No other source of potential bias identified \\
\hline
\end{tabular}

Samiee 2009

Methods Design: RCT


Samiee 2009 (Continued)

Participants

Setting: Arash Hospital, Tehran University of Medical Sciences

Country: Iran

40 women with SUI

Inclusion criteria: urinary incontinence with abdominal pressure $>60 \mathrm{~cm}$ which leads to water leak, or stress or positive test with cough if there was no catheter leak, increase in urethral mobility with positive answer in Maximal Straing Cotton-tipped Swab Test with $>30^{\circ}$

Exclusion criteria: previous surgery for urinary incontinence, patients with contraindication for GA and laparoscopy, increased in detrusor activity in urodynamic test, severe anterior vaginal prolapse and uterine prolapse and maximum urethra closure with pressure $>20 \mathrm{~cm}$ of water

\begin{tabular}{ll}
\hline Interventions & Group I $(n=16)$ : Burch LC \\
& Group II ( $n=19):$ TOT \\
& 5 women were lost to follow-up (4 in the LC group and \\
\hline Outcomes & Objective cure rate \\
Incontinence Quality of Life questionnaire (I-QOL) \\
Urinary Distress Inventory Short Form (UDI-6) \\
Severity of Urinary Incontinence questionnaire \\
Urodynamics \\
Operation time (min) \\
Length of stay \\
No significant differences in any outcome measures
\end{tabular}

Notes

\section{Risk of bias}

\section{Bias}

Random sequence genera- Unclear risk tion (selection bias)

Allocation concealment $\quad$ Unclear risk
(selection bias)

\begin{tabular}{|c|c|c|}
\hline $\begin{array}{l}\text { Blinding of participants } \\
\text { and personnel (perfor- } \\
\text { mance bias) } \\
\text { All outcomes }\end{array}$ & Unclear risk & No information \\
\hline $\begin{array}{l}\text { Blinding of outcome as- } \\
\text { sessment (detection bias) } \\
\text { All outcomes }\end{array}$ & Unclear risk & No information \\
\hline $\begin{array}{l}\text { Incomplete outcome data } \\
\text { (attrition bias) } \\
\text { All outcomes }\end{array}$ & Unclear risk & $\begin{array}{l}\text { A total of } 5 \text { women were lost to follow-up ( } 4 \text { in the LC group and } 1 \text { in the TOT } \\
\text { group). No reasons provided }\end{array}$ \\
\hline
\end{tabular}


Samiee 2009 (Continued)

Selective reporting (re- $\quad$ Unclear risk No information
porting bias)

Other bias Low risk No other source of potential bias identified

\section{Stangel-Wojcikiewicz 2008}

\begin{tabular}{|c|c|}
\hline Methods & Design: RCT \\
\hline \multirow[t]{4}{*}{ Participants } & 108 women \\
\hline & Age $34-78$ years \\
\hline & Inclusion criteria: urodynamically diagnosed GSI (USI) \\
\hline & $\begin{array}{l}\text { Exclusion criteria: OAB, DO, ISD (Valsalva leak point pressure }<65 \mathrm{~cm} \text { water, } \mathrm{MUCP}<20 \mathrm{~cm} \text { water); } \\
\text { prolapse grade } 3 \text { or } 4 \text {, diabetes, neurological disorders, any contraindication to laparoscopic or open } \\
\text { surgery }\end{array}$ \\
\hline \multirow[t]{2}{*}{ Interventions } & Group I $(n=51)$ : LC \\
\hline & Group II $(n=57):$ OC \\
\hline \multirow[t]{6}{*}{ Outcomes } & Stress test after surgery \\
\hline & Operating time (mean min) \\
\hline & Postoperative length of stay (mean h) \\
\hline & Blood loss (mean $\mathrm{mL}$ ) \\
\hline & Urine retention \\
\hline & Bladder perforation \\
\hline
\end{tabular}

Notes Other adverse effects in Group II: wound infection, retropubic haematoma, dyspareunia, throm-
bophlebitis

Follow-up: 18 months

This trial is a conference abstract with little detail reported. Trial author emailed for more data

\section{Risk of bias}

\begin{tabular}{lll}
\hline Bias & Authors' judgement & Support for judgement \\
\hline $\begin{array}{l}\text { Random sequence genera- } \\
\text { tion (selection bias) }\end{array}$ & Unclear risk & Randomised \\
\hline $\begin{array}{l}\text { Allocation concealment } \\
\text { (selection bias) }\end{array}$ & Unclear risk & Randomised \\
\hline $\begin{array}{l}\text { Blinding of participants } \\
\text { and personnel (perfor- } \\
\text { mance bias) }\end{array}$ & Unclear risk & Not possible \\
$\begin{array}{l}\text { All outcomes } \\
\text { Blinding of outcome as- } \\
\text { sessment (detection bias) }\end{array}$ & Unclear risk & No information \\
\hline
\end{tabular}


Stangel-Wojcikiewicz 2008 (Continued)

All outcomes

\begin{tabular}{lll}
\hline $\begin{array}{l}\text { Incomplete outcome data } \\
\text { (attrition bias) } \\
\text { All outcomes }\end{array}$ & Low risk & No dropouts \\
\hline $\begin{array}{l}\text { Selective reporting (re- } \\
\text { porting bias) }\end{array}$ & Unclear risk & No information \\
\hline Other bias & Unclear risk & This trial is a conference abstract with little detail reported
\end{tabular}

\section{Su 1997}

\begin{tabular}{ll}
\hline Methods & Design: quasi-RCT \\
\hline Participants & 92 women with urinary incontinence confirmed by pad test and objective stress test \\
& $\begin{array}{l}\text { Exclusion criteria: pathological conditions that might limit vaginal wall flexibility, uterine prolapse or } \\
\text { cytocele greater than first degree' DI, underactive detrusor or outflow obstruction, previous continence } \\
\text { surgery, previous hysterectomy }\end{array}$ \\
\hline Interventions & Group I $(n=46):$ LC using sutures \\
Group II $(n=46):$ OC
\end{tabular}

Outcomes Objective cure, 1-h pad test, urodynamics, operative time, blood loss, duration of bladder drainage, complications with 1 year

\begin{tabular}{ll}
\hline Notes & Follow-up: 1 year \\
& Most data not reported in useable form
\end{tabular}

\section{Risk of bias}

Bias Authors' judgement Support for judgement

Random sequence genera- High risk tion (selection bias)
Quote: "Patients were randomized according to a computer generated random number table; the group was assigned by opening the next sealed, opaque envelope. Only a few patients were unwilling to undergo laparoscopic colposuspension. They were, thus, enrolled in the traditional groups. Then, the next patient was assigned to the laparoscopic procedure and the following patients went back to the sequence of the random number table"

Allocation concealment High risk
(selection bias)

Quote: "Patients were randomized according to a computer generated random number table; the group was assigned by opening the next sealed, opaque envelope. Only a few patients were unwilling to undergo laparoscopic colposuspension. They were, thus, enrolled in the traditional groups. Then, the next patient was assigned to the laparoscopic procedure and the following patients went back to the sequence of the random number table"

\begin{tabular}{lll}
\hline $\begin{array}{l}\text { Blinding of participants } \\
\text { and personnel (perfor- } \\
\text { mance bias) }\end{array}$ & Unclear risk & Not reported \\
$\begin{array}{l}\text { All outcomes } \\
\begin{array}{l}\text { Blinding of outcome as- } \\
\text { sessment (detection bias) }\end{array}\end{array}$ & Unclear risk & Not reported \\
\hline
\end{tabular}


Su 1997 (Continued)

All outcomes

\begin{tabular}{lll}
$\begin{array}{l}\text { Incomplete outcome data } \\
\text { (attrition bias) } \\
\text { All outcomes }\end{array}$ & Low risk & Data provided for all participants \\
\hline $\begin{array}{l}\text { Selective reporting (re- } \\
\text { porting bias) }\end{array}$ & Low risk & Outcomes seem to be reported in full \\
\hline Other bias & Low risk & No other potential source of bias was identified \\
\hline
\end{tabular}

\section{Summitt 2000}

\begin{tabular}{ll}
\hline Methods & Design: RCT \\
\hline Participants & Setting: multicentre (5 sites) \\
& 62 women \\
Inclusion criteria: aged $21-75$, objective diagnosis of GSI with urine loss with cough and absence of de- \\
trusor activity with SUI, anatomic defect of urethrovesical junction (Q-tip deviation $>30^{\circ}$ from the hori- \\
zontal) \\
Exclusion criteria: need for concomitant surgical procedures, previous retropubic urethropexy, nee- \\
dle suspension or suburethral sling, neurologic deficit associated with incontinence, type III SUI, DI \\
that has not been treated and improved, absolute contraindications to laparoscopy (uterine fibroids or \\
pelvic masses $>16$ weeks' gestational size, conditions in which patient cannot tolerate anaesthesia, se- \\
vere bleeding disorders, acute peritonitis of upper abdomen with severe distension), pathology present \\
at the time of surgery that requires additional surgery (e.g. unsuspected ovarian mass)
\end{tabular}

$\begin{array}{ll}\text { Interventions } & \text { Group I }(\mathrm{n}=28) \text { : LC } \\ & \text { Group II }(\mathrm{n}=34): \text { OC } \\ & \text { To ensure similarity of operative technique, all coinvestigators met at a common location at begin- } \\ & \text { ning of trial to observe surgery and participate in animal laboratory. Intraperitoneal approach for la- } \\ & \text { paroscopy; } 0 \text {-Ethibond suture, } 2 \text { sutures each side of urethra; suprapubic catheter }\end{array}$

Outcomes

Operating time, blood loss, hospital stay, complications, fever, time to resumption of voiding, objective surgical success, urodynamics, time to return to work and normal activity, subjective success

Notes
$3 \mathrm{LCs}$ were converted to OCs due to severe intra-abdominal adhesions
Power calculation
Follow-up: 2 weeks, 6 weeks, 3 months and 1 year
This trial is a conference abstract with little detail reported.

\section{Risk of bias}

\begin{tabular}{lll}
\hline Bias & Authors' judgement & Support for judgement \\
\hline $\begin{array}{l}\text { Random sequence genera- } \\
\text { tion (selection bias) }\end{array}$ & Unclear risk & $\begin{array}{l}\text { Quote: "Randomly assigned to a laparoscopic or transabdominal Burch ure- } \\
\text { thropexy" }\end{array}$ \\
\hline $\begin{array}{l}\text { Allocation concealment } \\
\text { (selection bias) }\end{array}$ & Unclear risk & Not reported \\
\hline
\end{tabular}


Summitt 2000 (Continued)

Blinding of participants Unclear risk $\quad$ Not possible
and personnel (perfor-
mance bias)

All outcomes

\begin{tabular}{lll}
\hline Blinding of outcome as- & Unclear risk & Not reported \\
sessment (detection bias) &
\end{tabular}

All outcomes

Incomplete outcome data Unclear risk

Not reported. 28 and 34 analysed but number randomised not reported

(attrition bias)

unber randomised not reported

All outcomes

\begin{tabular}{lll}
\hline $\begin{array}{l}\text { Selective reporting (re- } \\
\text { porting bias) }\end{array}$ & Unclear risk & $\begin{array}{l}\text { Outcomes not reported in full e.g. "no statistical difference between complica- } \\
\text { tions, postoperative fever, and mean time to resumption of voiding." }\end{array}$ \\
\hline Other bias & Unclear risk & This trial is a conference abstract with little detail reported \\
\hline
\end{tabular}

Tuygun 2006

\begin{tabular}{|c|c|c|}
\hline Methods & \multicolumn{2}{|l|}{ Design: RCT } \\
\hline Participants & \multicolumn{2}{|c|}{60 women with primary SUI } \\
\hline \multirow[t]{2}{*}{ Interventions } & \multirow{2}{*}{\multicolumn{2}{|c|}{$\begin{array}{l}\text { Group I ( } n=27): \text { LC (mesh and tacks) } \\
\text { Group II ( } n=33): \text { OC ( } 2-0 \text { polyglactin sutures) }\end{array}$}} \\
\hline & & \\
\hline \multirow[t]{8}{*}{ Outcomes } & \multicolumn{2}{|c|}{ Complete cure defined as no need for any pads (subjective) } \\
\hline & \multicolumn{2}{|l|}{ Operation time } \\
\hline & \multicolumn{2}{|c|}{ Postoperative analgesia } \\
\hline & \multicolumn{2}{|l|}{ Blood loss } \\
\hline & \multicolumn{2}{|l|}{ Length of stay } \\
\hline & \multicolumn{2}{|c|}{ Duration of catheterisation } \\
\hline & \multicolumn{2}{|c|}{ Time to return to daily activities } \\
\hline & \multicolumn{2}{|l|}{ Cost } \\
\hline \multirow[t]{2}{*}{ Notes } & \multicolumn{2}{|c|}{$\begin{array}{l}\text { Adverse effects: Group I 2/27 ( } 1 \text { bladder perforation, } 1 \text { subcutaneous emphysema); } 2 \text { transient urinary } \\
\text { retention; Group II = } 1 \text { transient urinary retention, no bladder perforation }\end{array}$} \\
\hline & \multicolumn{2}{|c|}{ Follow-up: Group | 38.7 months +/- SD 10; Group || 42.1 (13.8) } \\
\hline \multicolumn{3}{|l|}{ Risk of bias } \\
\hline Bias & Authors' judgement & Support for judgement \\
\hline $\begin{array}{l}\text { Random sequence genera- } \\
\text { tion (selection bias) }\end{array}$ & Unclear risk & Quote: "Randomised" \\
\hline
\end{tabular}


Tuygun 2006 (Continued)

\begin{tabular}{|c|c|c|}
\hline $\begin{array}{l}\text { Allocation concealment } \\
\text { (selection bias) }\end{array}$ & Unclear risk & Randomised \\
\hline $\begin{array}{l}\text { Blinding of participants } \\
\text { and personnel (perfor- } \\
\text { mance bias) } \\
\text { All outcomes }\end{array}$ & Unclear risk & Not possible, not reported \\
\hline $\begin{array}{l}\text { Blinding of outcome as- } \\
\text { sessment (detection bias) } \\
\text { All outcomes }\end{array}$ & Unclear risk & Not reported \\
\hline $\begin{array}{l}\text { Incomplete outcome data } \\
\text { (attrition bias) } \\
\text { All outcomes }\end{array}$ & Unclear risk & All randomised participants included in analysis \\
\hline $\begin{array}{l}\text { Selective reporting (re- } \\
\text { porting bias) }\end{array}$ & Low risk & All outcomes specified in Methods reported in full in Results \\
\hline Other bias & Low risk & No other source of potential bias identified \\
\hline
\end{tabular}

Ustun 2003

\begin{tabular}{ll}
\hline Methods & Design: RCT \\
\hline Participants & Setting: tertiary care university hospital \\
& 46 consecutive women with proven GSI \\
& All participants were evaluated preoperatively with medical and voiding histories, physical examina- \\
tion, urinalysis, urine culture, multichannel urodynamics with cystometry, uroflowmetry, and measure- \\
ment of Valsalva leak-point pressure. \\
4 of TVT women had previous incontinence surgery, otherwise the groups were similar with respect to \\
age, parity and hormonal status.
\end{tabular}

Interventions Group I $(n=23)$ : LC (transperitoneal approach, 2 sutures each side under $G A)$
Group II ( $n=23)$ : TVT (5 LA and 10 spinal anaesthetic and $8 \mathrm{GA}$ )
Outcomes Operating time, length of catheterisation, hospital stay and surgical complications were recorded. Ob- jective assessment by urodynamics at 3 months. Subjective assessment (with questionnaire and pa- tient history) was also evaluated. Cure was defined as no need for pads and no leakage on urodynam- ics.
Notes
No clear exclusion/inclusion criteria
Group I: laparoscopy couldn't be completed in 2 (8.6\%) women due to intraoperative complications, so were converted to open procedures.
Group II: in the TVT group there were 2 (8.6\%) bladder lacerations but they did not need treatment.
Follow-up: subjectively at 3, 6, 12 and 18 months and objective cure at 3 months

\section{Risk of bias}

Bias Authors' judgement Support for judgement


Ustun 2003 (Continued)

Random sequence genera- Unclear risk Quote: "randomly allocated" tion (selection bias)

\begin{tabular}{lll}
\hline $\begin{array}{l}\text { Allocation concealment } \\
\text { (selection bias) }\end{array}$ & Unclear risk & Not reported \\
\hline $\begin{array}{l}\text { Blinding of participants } \\
\text { and personnel (perfor- }\end{array}$ & Unclear risk & Not possible \\
mance bias) & \\
All outcomes &
\end{tabular}

\begin{tabular}{lll}
\hline Blinding of outcome as- & Unclear risk & Not reported \\
sessment (detection bias)
\end{tabular}

All outcomes

Incomplete outcome data Low risk $\quad$ All randomised participants included in analysis
(attrition bias)

All outcomes

\begin{tabular}{lll}
\hline $\begin{array}{l}\text { Selective reporting (re- } \\
\text { porting bias) }\end{array}$ & High risk & $\begin{array}{l}\text { Methods state "follow-up visits 1, 3, 6, 12 and 18 months postoperatively" - } \\
\text { unclear if data are reported for these time points in Results }\end{array}$ \\
\hline Other bias & Low risk & No other source of potential bias identified \\
\hline
\end{tabular}

Ustun 2005

\begin{tabular}{|c|c|}
\hline Methods & Design: RCT \\
\hline \multirow[t]{7}{*}{ Participants } & Setting: Ankara University \\
\hline & Country: Turkey \\
\hline & 52 women \\
\hline & Age (mean years (SD) N): Group I = 43.62 (9.09) 26; Group II = 47.27 (5.41) 26 \\
\hline & Parity (median): Group I = 3; Group II = 4 \\
\hline & Inclusion criteria: GSI (USI), no previous continence surgery \\
\hline & Exclusion criteria: DI/DO \\
\hline \multirow[t]{5}{*}{ Interventions } & Group I $(n=26)$ : LC ( 2 sutures each side) \\
\hline & Group II ( $n=26)$ : OC Burch colposuspension ( 2 sutures each side) \\
\hline & Concomitant surgery allowed: \\
\hline & $\begin{array}{l}\text { Group I: } 3 \text { lap assisted vaginal hysterectomy; } 7 \text { posterior repair, } 9 \text { tubal ligation, } 4 \text { salpingo-oophorecto- } \\
\text { my, } 7 \text { cyst extirpation }\end{array}$ \\
\hline & $\begin{array}{l}\text { Group II: } 4 \text { hysterectomy; } 8 \text { posterior repair; } 9 \text { tubal ligation; } 2 \text { salpingo-oophorectomy; } 3 \text { cyst extirpa- } \\
\text { tion }\end{array}$ \\
\hline
\end{tabular}

Outcomes

Success subjective: history from woman, no use of pads

Success objective: stress test and urodynamics 
Ustun 2005 (Continued)

Success defined as subjectively dry, negative stress test and urodynamic evaluation (combined outcome)

Operating time

Hospital stay

Adverse effects

Bladder injury

Bleeding

DI

Urinary retention

Duration of catheterisation

Valsalva leak point pressure; Q-tip test angle; bladder capacity; first sensation of urine, maximum flow rate, maximum detrusor activity

Notes Comparison 3

\section{Risk of bias}

\begin{tabular}{lll}
\hline Bias & Authors' judgement & Support for judgement \\
\hline $\begin{array}{l}\text { Random sequence genera- } \\
\text { tion (selection bias) }\end{array}$ & Low risk & Computer-generated randomisation list \\
\hline $\begin{array}{l}\text { Allocation concealment } \\
\text { (selection bias) }\end{array}$ & Low risk & Consecutive sealed envelopes \\
\hline $\begin{array}{l}\text { Blinding of participants } \\
\text { and personnel (perfor- } \\
\text { mance bias) }\end{array}$ & Unclear risk & Not possible, not reported \\
All outcomes & \\
\hline $\begin{array}{l}\text { Blinding of outcome as- } \\
\text { sessment (detection bias) }\end{array}$ & Unclear risk & Not reported \\
All outcomes & \\
\hline $\begin{array}{l}\text { Incomplete outcome data } \\
\text { (attrition bias) }\end{array}$ & Low risk & No dropouts \\
\begin{tabular}{l} 
All outcomes \\
\hline $\begin{array}{l}\text { Selective reporting (re- } \\
\text { porting bias) }\end{array}$
\end{tabular} & Low risk & All outcomes reported \\
\hline \begin{tabular}{l} 
Other bias \\
\hline
\end{tabular} & Low risk & No other source of potential bias identified \\
\hline
\end{tabular}

\section{Valpas 2004}

\begin{tabular}{ll}
\hline Methods & Design: RCT comparing LC with TVT \\
\hline Participants & Setting: multicentre \\
& Country: Finland \\
\hline
\end{tabular}


Valpas 2004 (Continued)

128 women recruited from gynaecology clinic

Inclusion criteria: urodynamically proven SUI with positive stress test

Exclusion criteria: previous incontinent surgery, > 3 UTIs within 2 years, $>70$ years old, coincident other gynaecology surgery, unstable bladder in cystometry, urethral pressure $<20$, residual volume $>100 \mathrm{~mL}$ preoperatively

\begin{tabular}{|c|c|}
\hline Interventions & $\begin{array}{l}\text { Group I ( } n=51) \text { : LC, extraperitoneal approach, mesh ( } 2 \text { strips of polypropylene) and tacks used } \\
\text { Group II }(n=70): \text { TVT, LA and sedation }\end{array}$ \\
\hline Outcomes & $\begin{array}{l}\text { Primary outcomes: negative } 48 \text {-h pad test results }(<8 \mathrm{~g} / 48 \mathrm{~h}) \text { and secondary outcome measures in- } \\
\text { clude subjective cure of incontinence ( } 2 \text { symptom scores were assessed, the 'urinary Incontinence } \\
\text { severity score' and the 'Urge score'). KHQ and VAS were also used to assess the severity of inconti- } \\
\text { nence. Operative complications was also assessed. Length of patient stay, return to normal activities, } \\
\text { operation time and postoperative analgesia requirement }\end{array}$ \\
\hline \multirow[t]{6}{*}{ Notes } & 1 bladder perforation in each group \\
\hline & $1 \mathrm{LC}$ converted to $\mathrm{OC}$ \\
\hline & $\begin{array}{l}2 \text { participants in each group with urinary retention ( } 1 \text { TVT (Group II) had the tape loosened the next day, } \\
\text { all others treated with ISC). }\end{array}$ \\
\hline & Follow-up: 6 weeks and 1 year. Trial ongoing for a 5-year follow-up \\
\hline & 7 withdrawals and at 12 months Group I $n=49$ and Group II n = 66 \\
\hline & $\begin{array}{l}\text { 5-year outcome Valpas 2014: when all the women lost to follow-up were regarded as failures in the ITT } \\
\text { no difference in objective cure rates between the groups was seen }\end{array}$ \\
\hline
\end{tabular}

\section{Risk of bias}

\begin{tabular}{lll}
\hline Bias & Authors' judgement & Support for judgement \\
\hline $\begin{array}{l}\text { Random sequence genera- } \\
\text { tion (selection bias) }\end{array}$ & Low risk & $\begin{array}{l}\text { Quote: "Computer-generated randomization list that was kept in the random- } \\
\text { ization center. The investigator called the randomization center to enter the } \\
\text { patient in the allocated group." }\end{array}$
\end{tabular}

\begin{tabular}{lll}
\hline $\begin{array}{l}\text { Allocation concealment } \\
\text { (selection bias) }\end{array}$ & Low risk & $\begin{array}{l}\text { Quote: "The investigator called the randomization center to enter the patient } \\
\text { in the allocated group." }\end{array}$ \\
\hline $\begin{array}{l}\text { Blinding of participants } \\
\text { and personnel (perfor- } \\
\begin{array}{l}\text { mance bias) } \\
\text { All outcomes }\end{array}\end{array}$ & $\begin{array}{l}\text { Unclear risk } \\
\text { was possible" }\end{array}$ \\
\hline
\end{tabular}

\begin{tabular}{|c|c|c|}
\hline $\begin{array}{l}\text { Blinding of outcome as- } \\
\text { sessment (detection bias) } \\
\text { All outcomes }\end{array}$ & Unclear risk & $\begin{array}{l}\text { They were assessed according to the protocol by a research nurse and the doc- } \\
\text { tor in charge at the clinic, who often was not the surgeon who performed the } \\
\text { initial operation. }\end{array}$ \\
\hline
\end{tabular}

\begin{tabular}{lll}
\hline $\begin{array}{l}\text { Incomplete outcome data } \\
\text { (attrition bias) } \\
\text { All outcomes }\end{array}$ & Low risk & No differential dropout. Adequate explanation for dropouts \\
\hline $\begin{array}{l}\text { Selective reporting (re- } \\
\text { porting bias) }\end{array}$ & Low risk & Outcomes reported in full \\
\hline Other bias & Unclear risk & $\begin{array}{l}\text { The number of women recruited fell short of the target owing to limitations of } \\
\text { time and recruiting problems and for these reasons this trial was also stopped } \\
\text { prematurely. However, in this trial the groups were still considered to be com- }\end{array}$ \\
\hline
\end{tabular}


Valpas 2004 (Continued)

parable and the data were analysed without adjustment after stopping the trial. The trail was judged to be at unclear risk as it was not clear if this could have an impact on the overall result.

Wallwiener 1995

\begin{tabular}{ll}
\hline Methods & Design: RCT \\
\hline Participants & 22 women with recurrent SUI grade 2-3 \\
& $\begin{array}{l}\text { All had prior hysterectomy and at least } 1 \text { additional gynaecological operation } \\
\text { Inclusion criteria: flat passive urethral pressure profile (low maximum urethral closure pressure), hypo- } \\
\text { tonic urethra, motoric/sensoric urge component } \\
\text { Exclusion criteria: cysto- and rectocele or prolapse }\end{array}$ \\
\hline
\end{tabular}

Comparison of laparoscopic transperitoneal with extraperitoneal colposuspension
Group I: transperitoneal approach
Group II: extraperitoneal approach
Using paraurethral Goretex suture or mesh stapler fixation; all had cystoscopy to exclude bladder le-
sion and suprapubic catheter for drainage and residuals

\begin{tabular}{ll}
\hline Outcomes & $\begin{array}{l}\text { Duration of surgery, postoperative bleeding, voiding difficulties, complications, subjective evaluation, } \\
\text { urodynamics, postoperative clinical findings, perineal us for control of anatomic correction of bladder } \\
\text { neck descent }\end{array}$
\end{tabular}

Notes Adverse events: 1 bladder lesion, 1 DI, 1 transient urinary retention

Follow-up: 2-12 months

Groups too small, follow-up too short, no information about numbers in groups

\section{Risk of bias}

\begin{tabular}{|c|c|c|}
\hline Bias & Authors' judgement & Support for judgement \\
\hline $\begin{array}{l}\text { Random sequence genera- } \\
\text { tion (selection bias) }\end{array}$ & Unclear risk & $\begin{array}{l}\text { Quote: "According to the randomisation patients were allotted to either the la- } \\
\text { paroscopic or the extraperitoneal group." }\end{array}$ \\
\hline $\begin{array}{l}\text { Allocation concealment } \\
\text { (selection bias) }\end{array}$ & Unclear risk & Not reported \\
\hline $\begin{array}{l}\text { Blinding of participants } \\
\text { and personnel (perfor- } \\
\text { mance bias) } \\
\text { All outcomes }\end{array}$ & Unclear risk & Not reported \\
\hline $\begin{array}{l}\text { Blinding of outcome as- } \\
\text { sessment (detection bias) } \\
\text { All outcomes }\end{array}$ & Unclear risk & Not reported \\
\hline $\begin{array}{l}\text { Incomplete outcome data } \\
\text { (attrition bias) } \\
\text { All outcomes }\end{array}$ & Unclear risk & $\begin{array}{l}20 \text { participants randomised and analysed (but not analysed per group) } \\
\text { Quote: "The various subgroups of the study are, however, too small and fol- } \\
\text { low-up too short for detailed evaluation." }\end{array}$ \\
\hline
\end{tabular}


Wallwiener 1995 (Continued)

Selective reporting (re- Unclear risk No protocol. No prespecified outcomes reported
porting bias)

Other bias Low risk No other source of potential bias identified

Zullo 2001

\begin{tabular}{|c|c|}
\hline Methods & Design: RCT \\
\hline \multirow[t]{2}{*}{ Participants } & $\begin{array}{l}60 \text { women with either mild or moderate SUI were enrolled. All similar with regard to baseline character- } \\
\text { istics }\end{array}$ \\
\hline & $\begin{array}{l}\text { Exclusion criteria: previous gynaecological or incontinent surgery, } \mathrm{BMI}>30 \text {, prolapse } \geq 2 \text { nd degree, pre- } \\
\text { vious severe abdominal and/or pelvic infection, severe SUI (loss of urine on minimal activity) }\end{array}$ \\
\hline Interventions & $\begin{array}{l}\text { Group I }(n=30) \text { : transperitoneal LC with Ethibond sutures ( } 1-2 \text { each side) } \\
\text { Group II }(n=30) \text { : transperitoneal LC using mesh and tacks or staples }\end{array}$ \\
\hline \multirow[t]{9}{*}{ Outcomes } & $\begin{array}{l}\text { Intra- and postoperative complications were recorded, operating time, blood loss, catheterisation } \\
\text { time, resumption to spontaneous voiding, hospital stay. Objective measurement was involuntary loss } \\
\text { of urine during cough and Valsalva manoeuvre in standing position with the bladder filled to max. cys- } \\
\text { tometric capacity. VAS used to assess subjective failure }\end{array}$ \\
\hline & Subjective failure at 12,24 and 36 months \\
\hline & Objective failure at 12, 24 and 36 months \\
\hline & Perioperative complications (bladder perforations) \\
\hline & Voiding dysfunction in $24 \mathrm{~h}$ \\
\hline & DI \\
\hline & Blood loss (mean mL (SD) N) \\
\hline & Postoperative stay (mean days (SD) N) \\
\hline & Operative time \\
\hline
\end{tabular}

Notes

Power calculation

Follow-up: 3, 6, 12 months

Withdrawals: Group I = 1 due to adhesions, 2 due to lack of postoperative data; Group II = 2 due to adhesions, 2 due to lack of postoperative data

A total of 7 withdrew from the trial (Group I $n=27$; Group II $n=26$ )

\section{Risk of bias}

\begin{tabular}{lll}
\hline Bias & Authors' judgement & Support for judgement \\
\hline $\begin{array}{l}\text { Random sequence genera- } \\
\text { tion (selection bias) }\end{array}$ & Low risk & Computer-generated random number list \\
\hline $\begin{array}{l}\text { Allocation concealment } \\
\text { (selection bias) }\end{array}$ & Unclear risk & No information \\
\hline
\end{tabular}


Zullo 2001 (Continued)
Blinding of participants
Unclear risk
Not reported and personnel (performance bias)

All outcomes

\begin{tabular}{|c|c|c|}
\hline $\begin{array}{l}\text { Blinding of outcome as- } \\
\text { sessment (detection bias) } \\
\text { All outcomes }\end{array}$ & Low risk & $\begin{array}{l}\text { Researcher assessing objective outcome was blinded to the type of la- } \\
\text { paroscopy }\end{array}$ \\
\hline
\end{tabular}

\begin{tabular}{lll}
\hline $\begin{array}{l}\text { Incomplete outcome data } \\
\text { (attrition bias) } \\
\text { All outcomes }\end{array}$ & Low risk & No differential dropout \\
\hline $\begin{array}{l}\text { Selective reporting (re- } \\
\text { porting bias) }\end{array}$ & Low risk & All outcomes reported \\
\hline Other bias & Low risk & No other source of potential bias identified \\
\hline
\end{tabular}

BMI: body-mass index; CMG: cystometrogram; CNS: central nervous system; COAD: chronic obstructive airway disease; DO: detrusor overactivity; DI: detrusor instability; EBL: estimated blood loss; GA: general anaesthetic; GSI: genuine stress incontinence; HRT: hormone replacement therapy; IIQ: Incontinence Impact Questionnaire; ISC: intermittent self-catheterisation; ISD: intrinsic sphincter deficiency; ITT: intention-to-treat; KHQ: King's Health Questionnaire; LA: local anaesthetic; LC: laparoscopic colposuspension; MUCP: maximum urethral closure pressure; MUI: mixed urinary incontinence; OAB: overactive bladder; OC: open colposuspension; POP-Q: Pelvic Organ Prolapse Quantification System; QoL: quality of life; RCT: randomised controlled trial; SF-36: short-form 36 item health survey; SIIQ: Short Incontinence Impact Questionnaire; SUDI: Short Urinary Distress Inventory; SUI: stress urinary incontinence; TOT: transobturator tape; TVT: tension-free vaginal tape; UDI: Urogential Distress Inventory; US: ultrasound; USI: urodynamic stress incontinence; UTI: urinary tract infection; UUI: urgency urinary incontinence; VAS: visual analogue score/scale

Characteristics of excluded studies [ordered by study ID]

\begin{tabular}{ll}
\hline Study & Reason for exclusion \\
\hline Choi 2006 & Prospective study of TOT versus laparoscopic colposuspension; no mention of randomisation \\
\hline Foote 2007 & $\begin{array}{l}\text { Randomisation broke down when } 1 \text { recruitment source only referred patients for laparoscopic pro- } \\
\text { cedure. This led to the study continuing as a cohort study to } 2 \text { surgical techniques, so was excluded } \\
\text { from this review. }\end{array}$ \\
\hline ISRCTN44339585 & Did not start recruitment (confirmed from personal correspondence with Dr Karen Boyd) \\
\hline Koster 1996 & $\begin{array}{l}\text { Comparing 2-dimensional view laparoscopy to 3-dimensional laparoscopy for different gynaeco- } \\
\text { logical operations; } n=3 \text { for colposuspension, all randomly allocated to 1 group }\end{array}$ \\
\hline Lee 1997 & $\begin{array}{l}\text { Comparison of the clinical course and results between laparoscopic and open Burch colposuspen- } \\
\text { sion. Not a randomised study }\end{array}$ \\
\hline Lernis 1997 & $\begin{array}{l}\text { Not a randomised study and only reporting experience with laparoscopic colposuspension tech- } \\
\text { nique }\end{array}$ \\
\hline NCT00573703 & \begin{tabular}{l} 
RCT of laparoscopic colposuspension versus TOT but trial withdrawn as did not start \\
\hline Prezioso 2013
\end{tabular} \\
\hline $\begin{array}{l}\text { Prospective study of laparoscopic Burch colposuspension only, no comparator group provided (the } \\
\text { article has now been retracted, for further details please see: BMC Surg 2016;16:26. doi: 10.1186/ } \\
\text { s12893-016-0141-6. PMC4848875). }\end{array}$ \\
\hline
\end{tabular}




\begin{tabular}{ll}
\hline Study & Reason for exclusion \\
\hline Salam 2004 & $\begin{array}{l}\text { Comparison of operative complications and early results between laparoscopic and open colpo- } \\
\text { suspension. Design not stated and not a randomised study }\end{array}$ \\
\hline
\end{tabular}

RCT: randomised controlled trial; TOT: transobturator tape

DATA AND ANALYSES

Comparison 1. Laparoscopic colposuspension versus open colposuspension

\begin{tabular}{|c|c|c|c|c|}
\hline Outcome or subgroup title & $\begin{array}{l}\text { No. of } \\
\text { studies }\end{array}$ & $\begin{array}{l}\text { No. of } \\
\text { partici- } \\
\text { pants }\end{array}$ & Statistical method & Effect size \\
\hline $\begin{array}{l}1 \text { Subjective cure within } 18 \\
\text { months }\end{array}$ & 8 & 1117 & Risk Ratio (M-H, Random, 95\% Cl) & $0.92[0.81,1.05]$ \\
\hline $\begin{array}{l}\text { 1.1 Laparoscopic colposuspen- } \\
\text { sion using sutures }\end{array}$ & 6 & 755 & Risk Ratio (M-H, Random, 95\% Cl) & $1.04[0.99,1.08]$ \\
\hline $\begin{array}{l}\text { 1.2 Laparoscopic colposuspen- } \\
\text { sion using mesh and staples }\end{array}$ & 3 & 362 & Risk Ratio (M-H, Random, 95\% Cl) & $0.75[0.61,0.93]$ \\
\hline $\begin{array}{l}2 \text { Subjective cure from } 18 \\
\text { months up to } 5 \text { years }\end{array}$ & 2 & 323 & Risk Ratio (M-H, Fixed, 95\% Cl) & $0.94[0.77,1.14]$ \\
\hline $\begin{array}{l}2.1 \text { Laparoscopic colposuspen- } \\
\text { sion using sutures }\end{array}$ & 1 & 263 & Risk Ratio (M-H, Fixed, 95\% Cl) & $1.00[0.81,1.25]$ \\
\hline $\begin{array}{l}\text { 2.2 Laparoscopic colposuspen- } \\
\text { sion using mesh and staples }\end{array}$ & 1 & 60 & Risk Ratio (M-H, Fixed, 95\% Cl) & $0.71[0.47,1.08]$ \\
\hline $\begin{array}{l}3 \text { Objective cure within } 18 \\
\text { months }\end{array}$ & 9 & 1117 & Risk Ratio (M-H, Random, 95\% Cl) & $0.94[0.86,1.02]$ \\
\hline $\begin{array}{l}3.1 \text { Laparoscopic colposuspen- } \\
\text { sion using sutures }\end{array}$ & 8 & 830 & Risk Ratio (M-H, Random, 95\% Cl) & $0.97[0.89,1.06]$ \\
\hline $\begin{array}{l}\text { 3.2 Laparoscopic colposuspen- } \\
\text { sion using mesh and staples }\end{array}$ & 2 & 287 & Risk Ratio (M-H, Random, 95\% Cl) & $0.81[0.72,0.91]$ \\
\hline $\begin{array}{l}4 \text { Objective cure from } 18 \\
\text { months up to } 5 \text { years }\end{array}$ & 2 & 290 & Risk Ratio (M-H, Random, 95\% Cl) & $0.82[0.41,1.63]$ \\
\hline $\begin{array}{l}\text { 4.1 Laparoscopic colposuspen- } \\
\text { sion using sutures }\end{array}$ & 2 & 290 & Risk Ratio (M-H, Random, 95\% Cl) & $0.82[0.41,1.63]$ \\
\hline 5 Objective cure after 5 years & 2 & 107 & Risk Ratio (M-H, Random, 95\% Cl) & $0.89[0.28,2.80]$ \\
\hline 6 Length of inpatient stay (days) & 8 & 1142 & Mean Difference (IV, Random, 95\% CI) & $-1.20[-1.84,-0.56]$ \\
\hline $\begin{array}{l}7 \text { Time to return to daily activi- } \\
\text { ties (days) }\end{array}$ & 4 & 401 & Mean Difference (IV, Random, 95\% CI) & $-14.27[-25.17,-3.38]$ \\
\hline
\end{tabular}




\begin{tabular}{|c|c|c|c|c|}
\hline Outcome or subgroup title & $\begin{array}{l}\text { No. of } \\
\text { studies }\end{array}$ & $\begin{array}{l}\text { No. of } \\
\text { partici- } \\
\text { pants }\end{array}$ & Statistical method & Effect size \\
\hline 8 Operation time (minutes) & 7 & 928 & Mean Difference (IV, Random, 95\% CI) & $21.80[10.59,33.01]$ \\
\hline $\begin{array}{l}8.1 \text { Laparoscopic colposuspen- } \\
\text { sion using sutures }\end{array}$ & 5 & 549 & Mean Difference (IV, Random, 95\% CI) & $25.27[6.21,44.33]$ \\
\hline $\begin{array}{l}8.2 \text { Laparoscopic colposuspen- } \\
\text { sion using mesh and staples }\end{array}$ & 3 & 379 & Mean Difference (IV, Random, 95\% CI) & $16.77[6.59,26.95]$ \\
\hline 9 Blood loss (mL) & 9 & 940 & Mean Difference (IV, Random, 95\% CI) & $-87.64[-141.70,-33.58]$ \\
\hline $\begin{array}{l}10 \text { Duration of catheterisation } \\
\text { (days) }\end{array}$ & 4 & 449 & Mean Difference (IV, Random, 95\% CI) & $-2.39[-3.48,-1.30]$ \\
\hline $\begin{array}{l}11 \text { Perioperative complications } \\
\text { (number of events) }\end{array}$ & 11 & 1369 & Risk Ratio (M-H, Random, 95\% Cl) & $0.67[0.47,0.94]$ \\
\hline $\begin{array}{l}\text { 11.1 Laparoscopic colposuspen- } \\
\text { sion using sutures }\end{array}$ & 9 & 1003 & Risk Ratio (M-H, Random, 95\% Cl) & $0.71[0.57,0.89]$ \\
\hline $\begin{array}{l}11.2 \text { Laparoscopic colposuspen- } \\
\text { sion using mesh and staples }\end{array}$ & 3 & 366 & Risk Ratio (M-H, Random, 95\% Cl) & $0.54[0.20,1.46]$ \\
\hline 12 Bladder perforations & 10 & 1311 & Risk Ratio (M-H, Fixed, 95\% Cl) & $1.72[0.90,3.29]$ \\
\hline $\begin{array}{l}\text { 12.1 Laparoscopic colposuspen- } \\
\text { sion using sutures }\end{array}$ & 8 & 957 & Risk Ratio (M-H, Fixed, 95\% Cl) & $2.15[0.97,4.77]$ \\
\hline $\begin{array}{l}\text { 12.2 Laparoscopic colposuspen- } \\
\text { sion using mesh and staples }\end{array}$ & 3 & 354 & Risk Ratio (M-H, Fixed, 95\% Cl) & $1.00[0.30,3.25]$ \\
\hline $\begin{array}{l}13 \text { De novo detrusor overactivi- } \\
\text { ty (urodynamic diagnosis) }\end{array}$ & 6 & & Risk Ratio (M-H, Fixed, 95\% Cl) & Subtotals only \\
\hline 13.1 Within 18 months & 5 & 472 & Risk Ratio (M-H, Fixed, 95\% Cl) & $1.29[0.72,2.30]$ \\
\hline $\begin{array}{l}13.2 \text { Between } 18 \text { months and } 5 \\
\text { years }\end{array}$ & 1 & 50 & Risk Ratio (M-H, Fixed, 95\% Cl) & $1.0[0.07,15.12]$ \\
\hline 13.3 After 5 years & 2 & 107 & Risk Ratio (M-H, Fixed, 95\% Cl) & $1.22[0.40,3.75]$ \\
\hline $\begin{array}{l}14 \text { Voiding dysfunction within } \\
18 \text { months }\end{array}$ & 5 & 507 & Risk Ratio (M-H, Fixed, 95\% Cl) & $0.81[0.50,1.31]$ \\
\hline 15 Quality of life & 2 & & Std. Mean Difference (IV, Random, 95\% CI) & Subtotals only \\
\hline 15.1 EQ-5D and SUDI & 2 & 491 & Std. Mean Difference (IV, Random, 95\% CI) & $0.10[-0.08,0.27]$ \\
\hline 15.2 EQ-5D and SIIQ & 2 & 491 & Std. Mean Difference (IV, Random, 95\% CI) & $0.11[-0.07,0.29]$ \\
\hline
\end{tabular}


Analysis 1.1. Comparison 1 Laparoscopic colposuspension versus open colposuspension, Outcome 1 Subjective cure within 18 months.

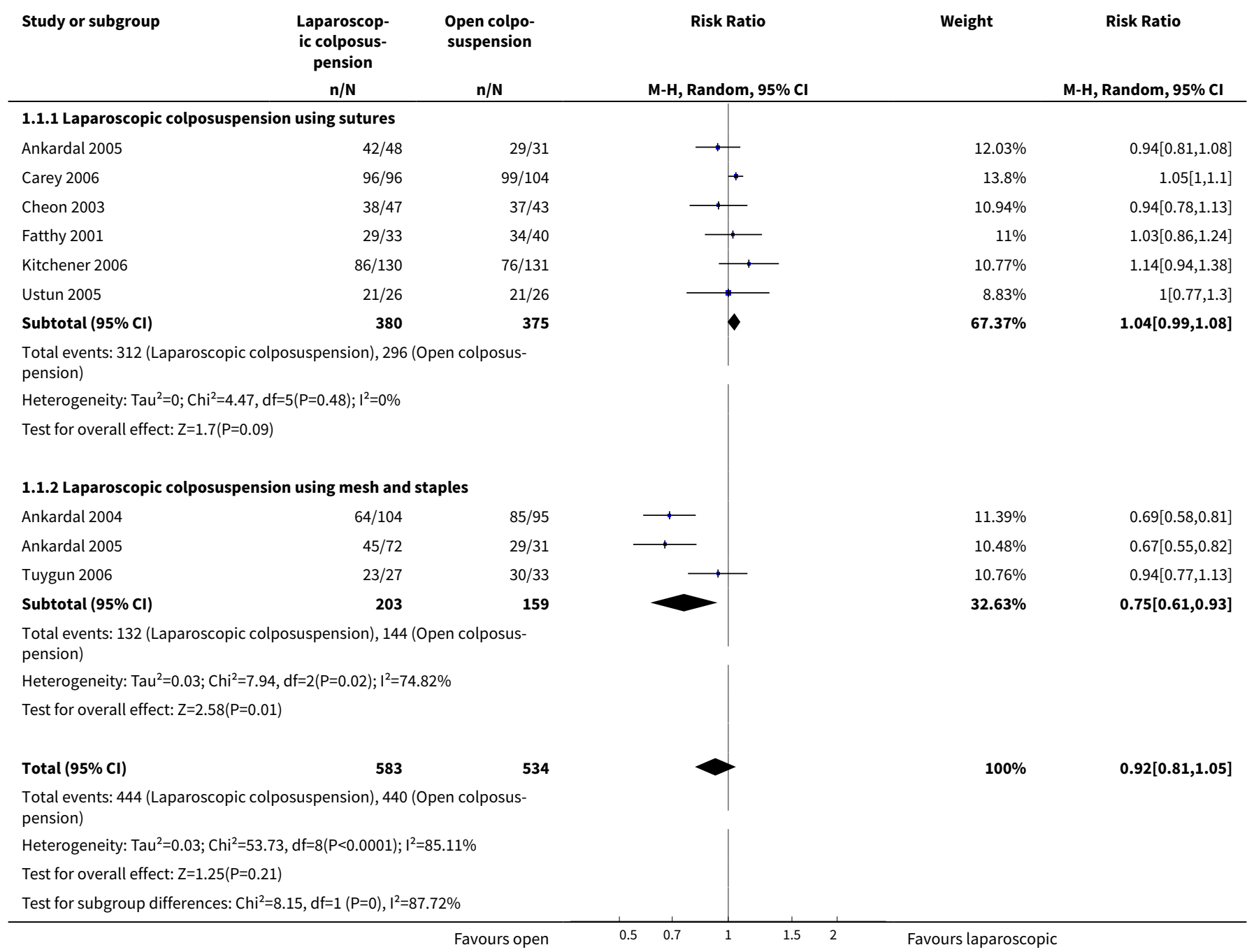

Analysis 1.2. Comparison 1 Laparoscopic colposuspension versus open colposuspension, Outcome 2 Subjective cure from 18 months up to 5 years.

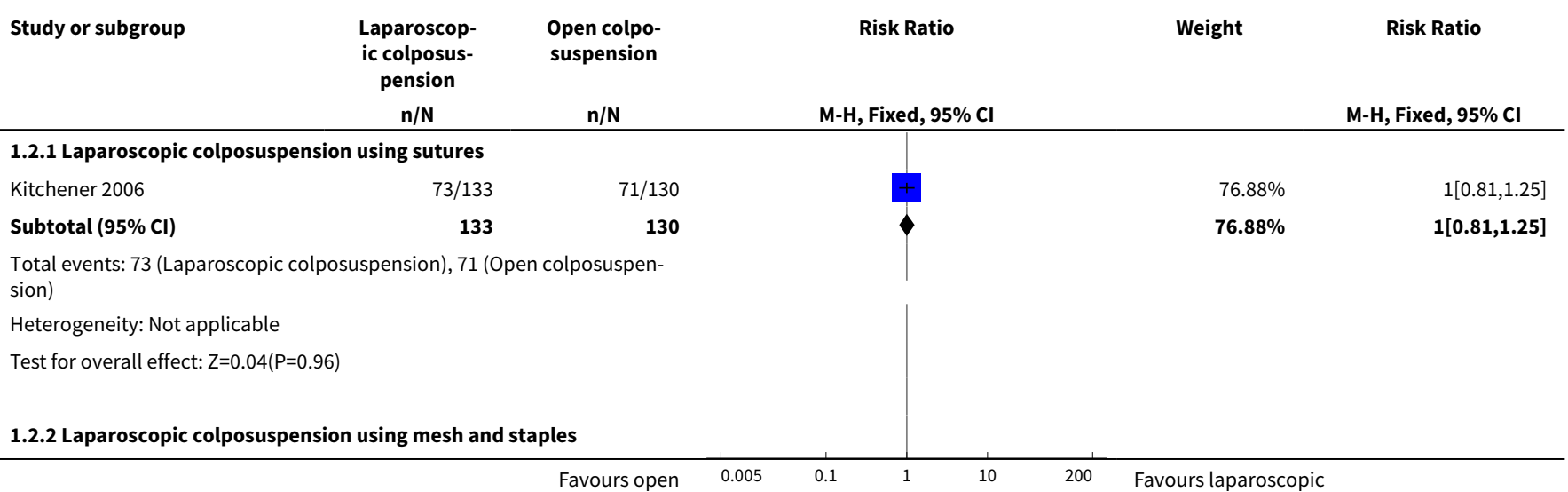




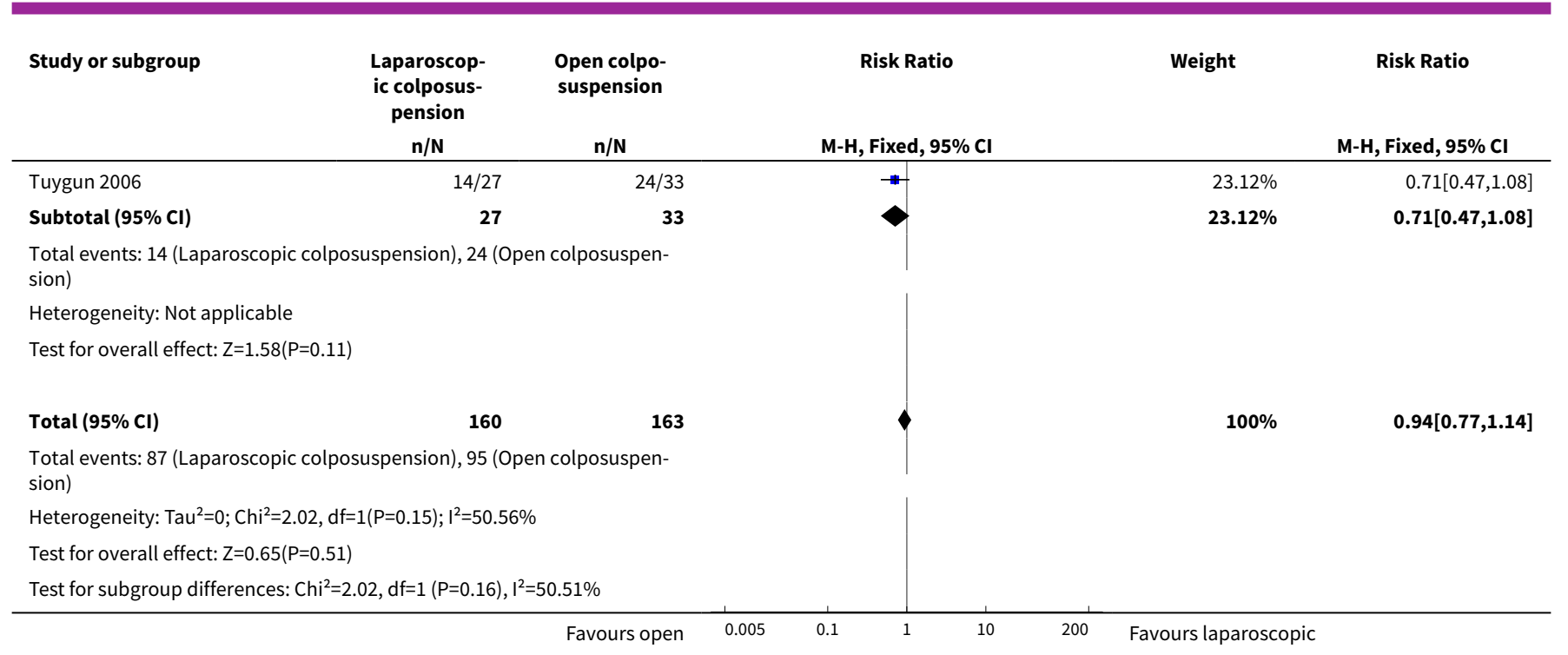

\section{Analysis 1.3. Comparison 1 Laparoscopic colposuspension versus open colposuspension, Outcome 3 Objective cure within 18 months.}

\begin{tabular}{|c|c|c|c|c|c|}
\hline Study or subgroup & $\begin{array}{l}\text { Laparoscop- } \\
\text { ic colposus- } \\
\text { pension }\end{array}$ & $\begin{array}{l}\text { Open colpo- } \\
\text { suspension }\end{array}$ & Risk Ratio & Weight & Risk Ratio \\
\hline & $n / N$ & $n / N$ & M-H, Random, 95\% Cl & & M-H, Random, $95 \% \mathrm{Cl}$ \\
\hline
\end{tabular}

$\begin{array}{lrr}\text { 1.3.1 Laparoscopic colposuspension using sutures } & \\ \text { Ankardal 2005 } & 43 / 48 & 23 / 30 \\ \text { Burton } 1997 & 21 / 29 & 27 / 28 \\ \text { Carey 2006 } & 66 / 96 & 83 / 104 \\ \text { Cheon 2003 } & 40 / 47 & 37 / 43 \\ \text { Fatthy 2001 } & 29 / 33 & 34 / 40 \\ \text { Kitchener 2006 } & 90 / 116 & 90 / 112 \\ \text { Summitt 2000 } & 22 / 24 & 24 / 28 \\ \text { Ustun 2005 } & 21 / 26 & 21 / 26 \\ \text { Subtotal (95\% CI) } & \mathbf{4 1 9} & \mathbf{4 1 1}\end{array}$

Total events: 332 (Laparoscopic colposuspension), 339 (Open colposuspension)

Heterogeneity: $\mathrm{Tau}^{2}=0.01 ; \mathrm{Chi}^{2}=10.97, \mathrm{df}=7(\mathrm{P}=0.14) ; \mathrm{I}^{2}=36.2 \%$

Test for overall effect: $\mathrm{Z}=0.66(\mathrm{P}=0.51)$

1.3.2 Laparoscopic colposuspension using mesh and staples

Ankardal 2004

Ankardal 2005

$71 / 96$

$44 / 70$

166

$84 / 91$

$22 / 30$

Subtotal $(95 \% \mathrm{Cl})$

M-H, Random, $95 \% \mathrm{Cl}$

$1.17[0.94,1.46]$ $0.75[0.59,0.95]$

$0.86[0.73,1.02]$

$0.99[0.83,1.17]$

$1.03[0.86,1.24]$

$0.97[0.84,1.1]$

$1.07[0.88,1.3]$

$1[0.77,1.3]$

$0.97[0.89,1.06]$

Total events: 115 (Laparoscopic colposuspension), 106 (Open colposuspension)

Heterogeneity: $\mathrm{Tau}^{2}=0 ; \mathrm{Chi}^{2}=0.19, \mathrm{df}=1(\mathrm{P}=0.66) ; \mathrm{I}^{2}=0 \%$

Test for overall effect: $Z=3.42(P=0)$

Total $(95 \% \mathrm{Cl})$

585

532

Total events: 447 (Laparoscopic colposuspension), 445 (Open colposuspension)

Heterogeneity: $\mathrm{Tau}^{2}=0.01 ; \mathrm{Chi}^{2}=17.84, \mathrm{df}=9(\mathrm{P}=0.04) ; \mathrm{I}^{2}=49.56 \%$

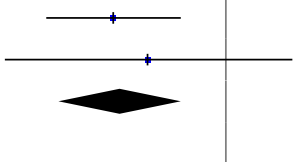




\begin{tabular}{|c|c|c|c|c|c|}
\hline \multirow[t]{2}{*}{ Study or subgroup } & $\begin{array}{l}\text { Laparoscop- } \\
\text { ic colposus- } \\
\text { pension }\end{array}$ & $\begin{array}{l}\text { Open colpo- } \\
\text { suspension }\end{array}$ & Risk Ratio & \multirow[t]{2}{*}{ Weight } & Risk Ratio \\
\hline & $n / N$ & $n / N$ & M-H, Random, 95\% Cl & & M-H, Random, $95 \% \mathrm{Cl}$ \\
\hline \multicolumn{6}{|c|}{ Test for overall effect: $Z=1.46(P=0.14)$} \\
\hline \multicolumn{6}{|c|}{ Test for subgroup differences: $\mathrm{Chi}^{2}=5.92, \mathrm{df}=1(\mathrm{P}=0.01), \mathrm{I}^{2}=83.11 \%$} \\
\hline
\end{tabular}

Analysis 1.4. Comparison 1 Laparoscopic colposuspension versus open colposuspension, Outcome 4 Objective cure from 18 months up to 5 years.

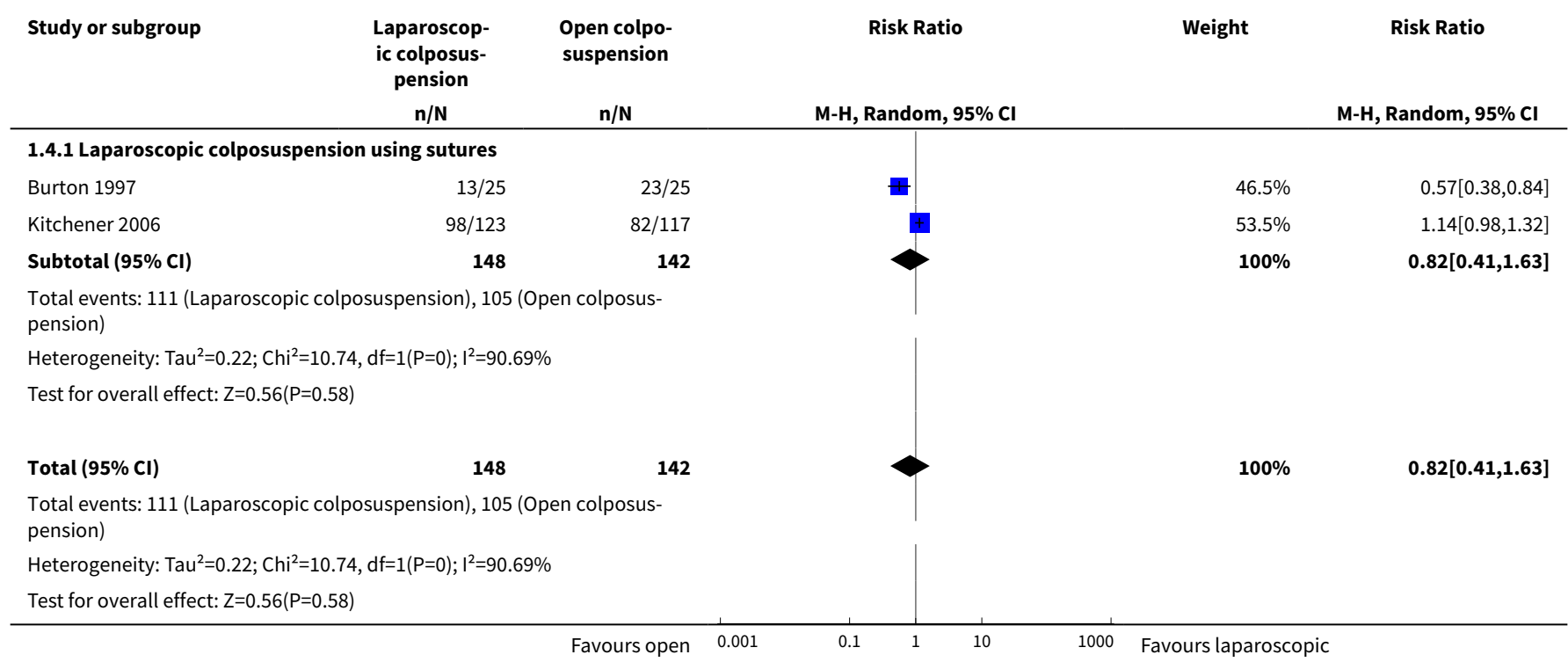

\section{Analysis 1.5. Comparison 1 Laparoscopic colposuspension versus open colposuspension, Outcome 5 Objective cure after 5 years.}

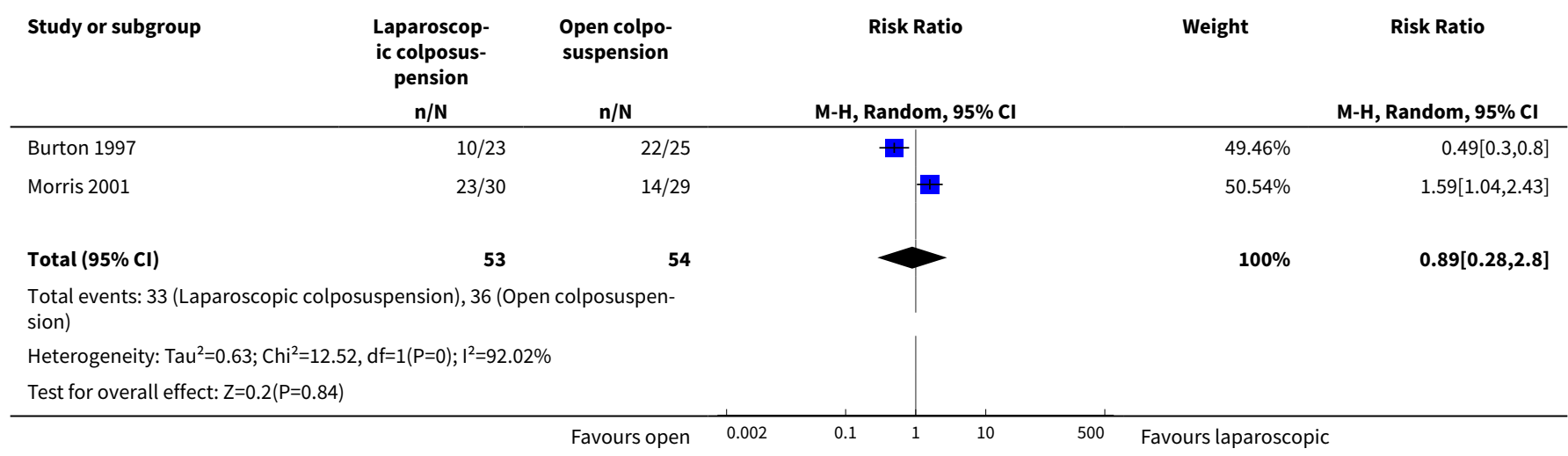


Analysis 1.6. Comparison 1 Laparoscopic colposuspension versus open colposuspension, Outcome 6 Length of inpatient stay (days).

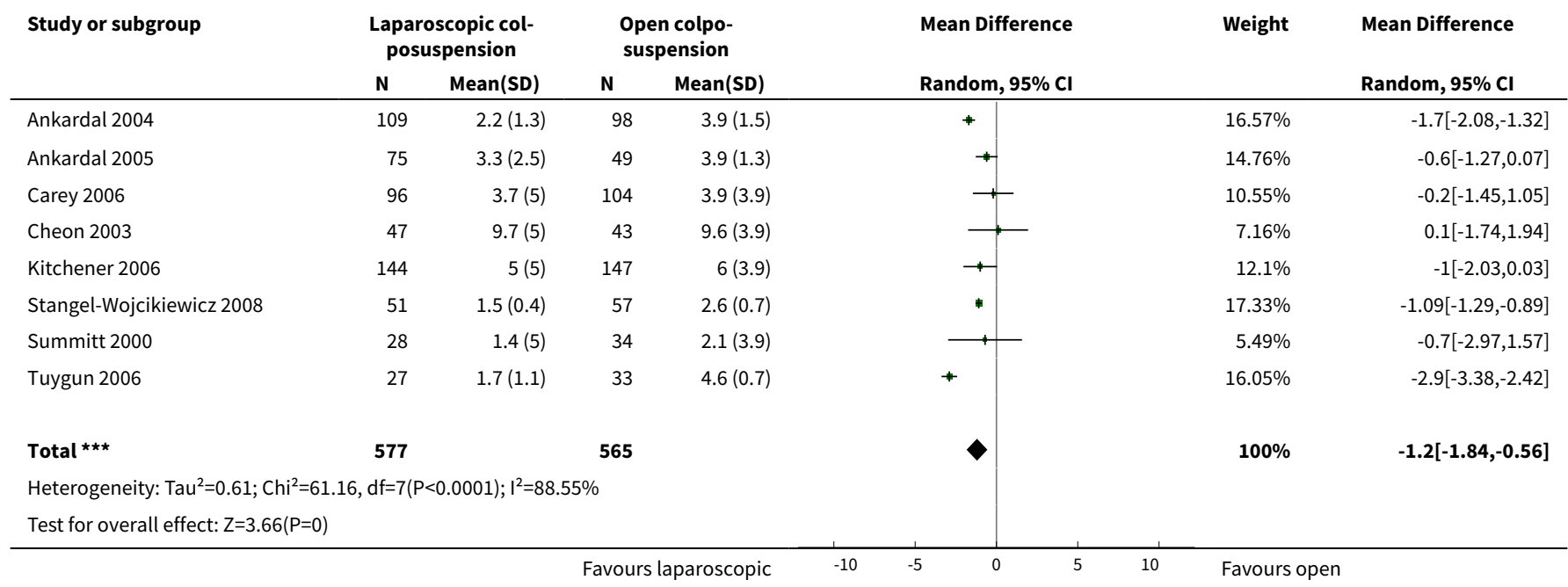

\section{Analysis 1.7. Comparison 1 Laparoscopic colposuspension versus open colposuspension, Outcome 7 Time to return to daily activities (days).}

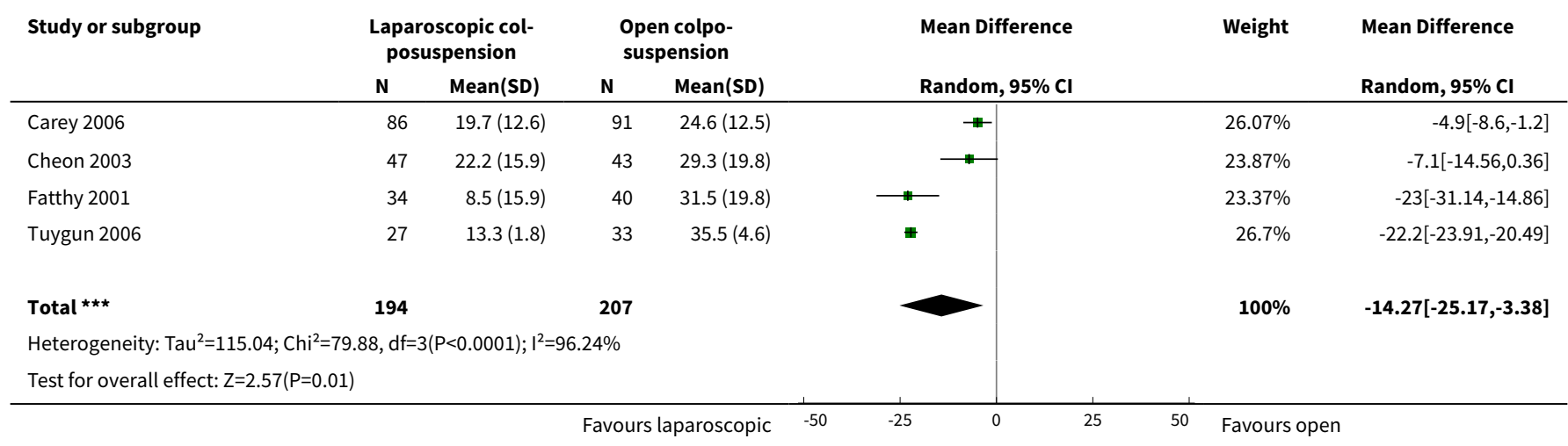

\section{Analysis 1.8. Comparison 1 Laparoscopic colposuspension versus open colposuspension, Outcome 8 Operation time (minutes).}

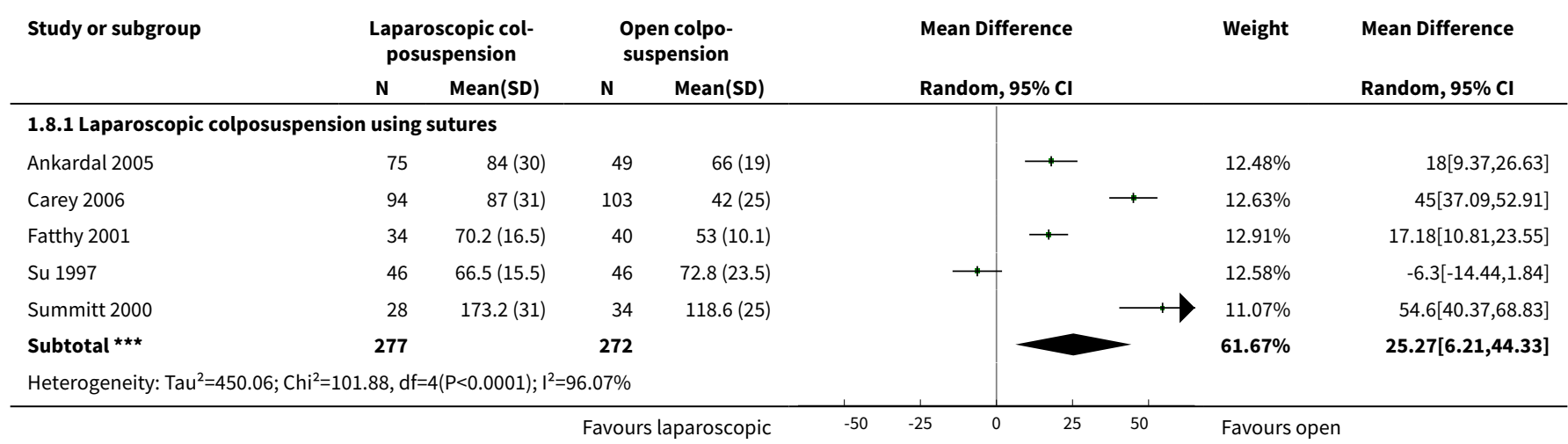




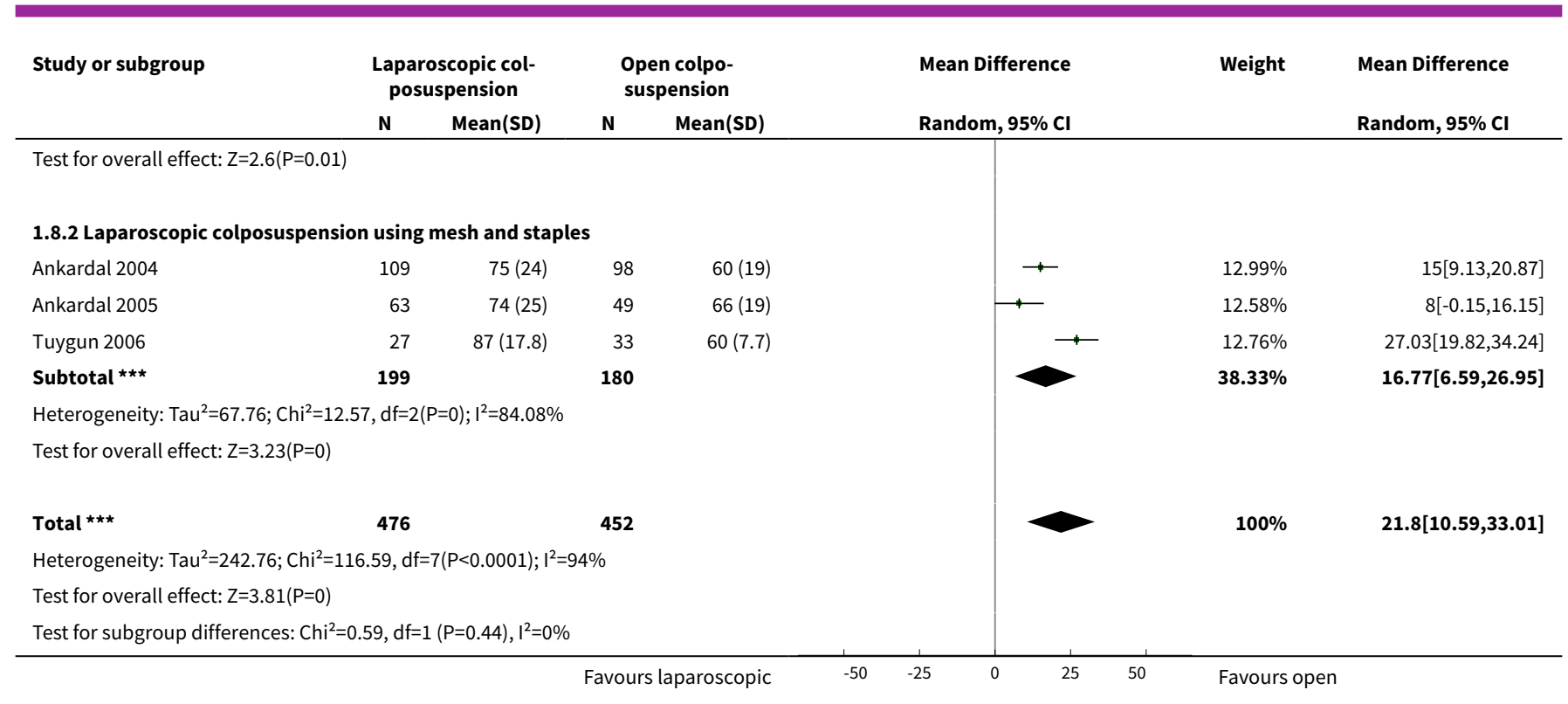

\section{Analysis 1.9. Comparison 1 Laparoscopic colposuspension versus open colposuspension, Outcome 9 Blood loss $(\mathrm{mL})$.}

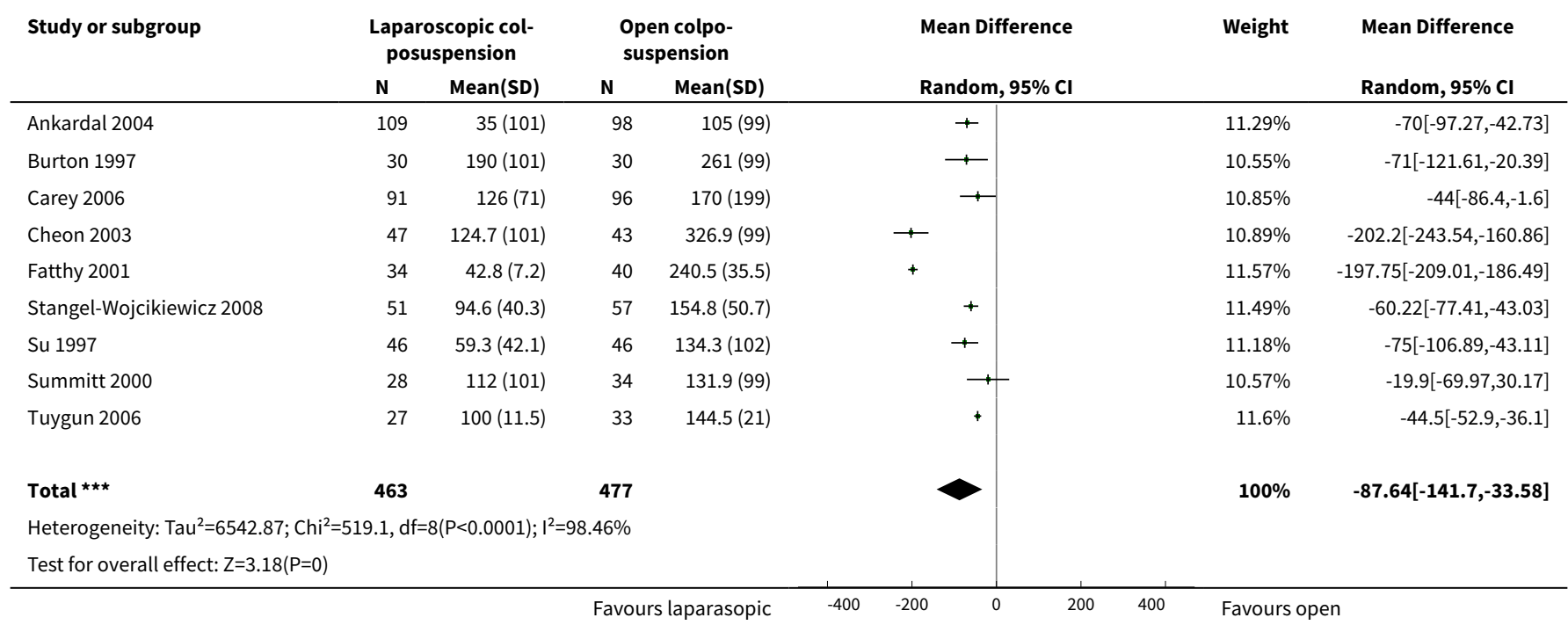

Analysis 1.10. Comparison 1 Laparoscopic colposuspension versus open colposuspension, Outcome 10 Duration of catheterisation (days).

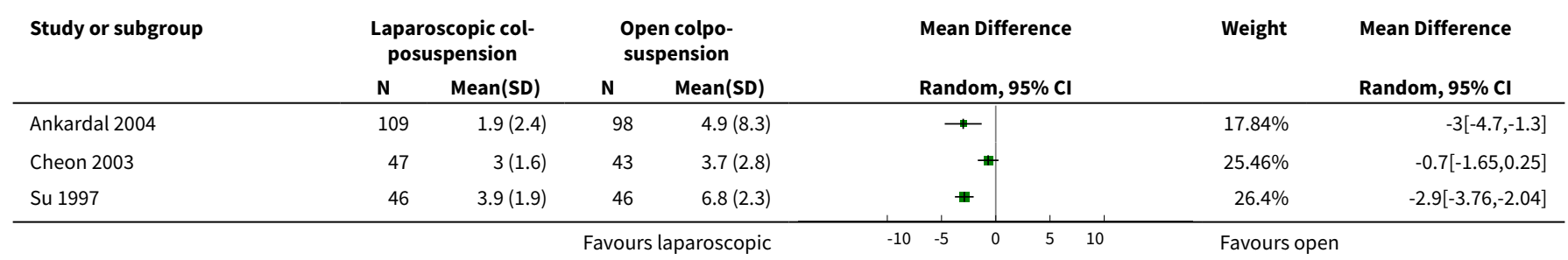




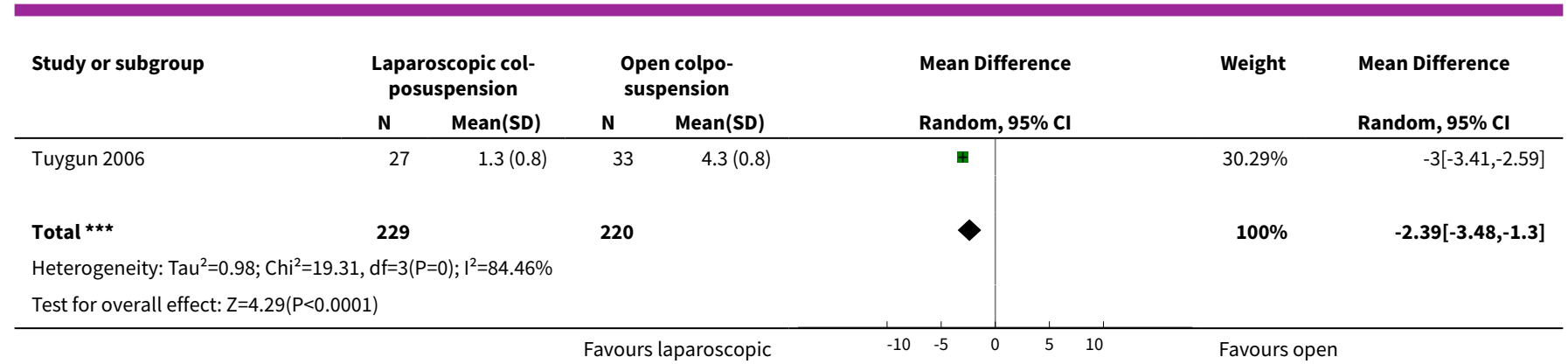

Analysis 1.11. Comparison 1 Laparoscopic colposuspension versus open colposuspension, Outcome 11 Perioperative complications (number of events).

\begin{tabular}{lrr} 
Study or subgroup & $\begin{array}{c}\text { Laparoscop- } \\
\text { ic colposus- } \\
\text { pension } \\
\text { n/N }\end{array}$ & $\begin{array}{c}\text { Open colpo- } \\
\text { suspension }\end{array}$ \\
\hline 1.11.1 Laparoscopic colposuspension using sutures & n/N \\
Ankardal 2005 & $37 / 75$ & $19 / 25$ \\
Burton 1997 & $2 / 30$ & $3 / 30$ \\
Carey 2006 & $6 / 96$ & $1 / 104$ \\
Cheon 2003 & $11 / 47$ & $15 / 43$ \\
Fatthy 2001 & $2 / 33$ & $4 / 40$ \\
Kitchener 2006 & $20 / 131$ & $30 / 143$ \\
Su 1997 & $5 / 46$ & $8 / 46$ \\
Summitt 2000 & $3 / 28$ & $2 / 34$ \\
Ustun 2005 & $6 / 26$ & $6 / 26$ \\
Subtotal (95\% CI) & $\mathbf{5 1 2}$ & $\mathbf{4 9 1}$
\end{tabular}

Total events: 92 (Laparoscopic colposuspension), 88 (Open colposuspension)

Heterogeneity: $\mathrm{Tau}^{2}=0 ; \mathrm{Chi}^{2}=6.87, \mathrm{df}=8(\mathrm{P}=0.55) ; \mathrm{I}^{2}=0 \%$

Test for overall effect: $Z=2.92(P=0)$

1.11.2 Laparoscopic colposuspension using mesh and staples

$\begin{array}{lrr}\text { Ankardal 2004 } & 15 / 109 & 26 / 98 \\ \text { Ankardal 2005 } & 15 / 75 & 18 / 24 \\ \text { Tuygun 2006 } & 4 / 27 & 1 / 33 \\ \text { Subtotal (95\% CI) } & \mathbf{2 1 1} & \mathbf{1 5 5}\end{array}$

Subtotal $(95 \% \mathrm{CI})$

211

Risk Ratio

Weight

Risk Ratio

M-H, Random, $95 \% \mathrm{Cl}$

Total events: 34 (Laparoscopic colposuspension), 45 (Open colposuspension)

Heterogeneity: $\mathrm{Tau}^{2}=0.52 ; \mathrm{Chi}^{2}=9.44, \mathrm{df}=2(\mathrm{P}=0.01) ; \mathrm{I}^{2}=78.8 \%$

Test for overall effect: $Z=1.21(P=0.23)$

Total $(95 \% \mathrm{Cl})$

723

M-H, Random, $95 \% \mathrm{CI}$

$0.65[0.47,0.89]$

$0.67[0.12,3.71]$

$6.5[0.8,53.01]$

$0.67[0.35,1.3]$

$0.61[0.12,3.1]$

$0.73[0.44,1.22]$

$0.63[0.22,1.77]$

$7.13 \%$

$3.35 \%$

$1.82[0.33,10.15]$

$1[0.37,2.7]$

$7.57 \%$

$0.71[0.57,0.89]$ pension)

Heterogeneity: Tau $^{2}=0.15 ; \mathrm{Chi}^{2}=23.09, \mathrm{df}=11(\mathrm{P}=0.02) ; \mathrm{I}^{2}=52.36 \%$

Test for overall effect: $Z=2.29(P=0.02)$

Test for subgroup differences: $\mathrm{Chi}^{2}=0.27, \mathrm{df}=1(\mathrm{P}=0.6), \mathrm{I}^{2}=0 \%$

Favours laparoscopic

$13.02 \%$

$14.13 \%$

$2.31 \%$

$29.47 \%$

$100 \%$

$0.67[0.47,0.94]$ 
Analysis 1.12. Comparison 1 Laparoscopic colposuspension
versus open colposuspension, Outcome 12 Bladder perforations.

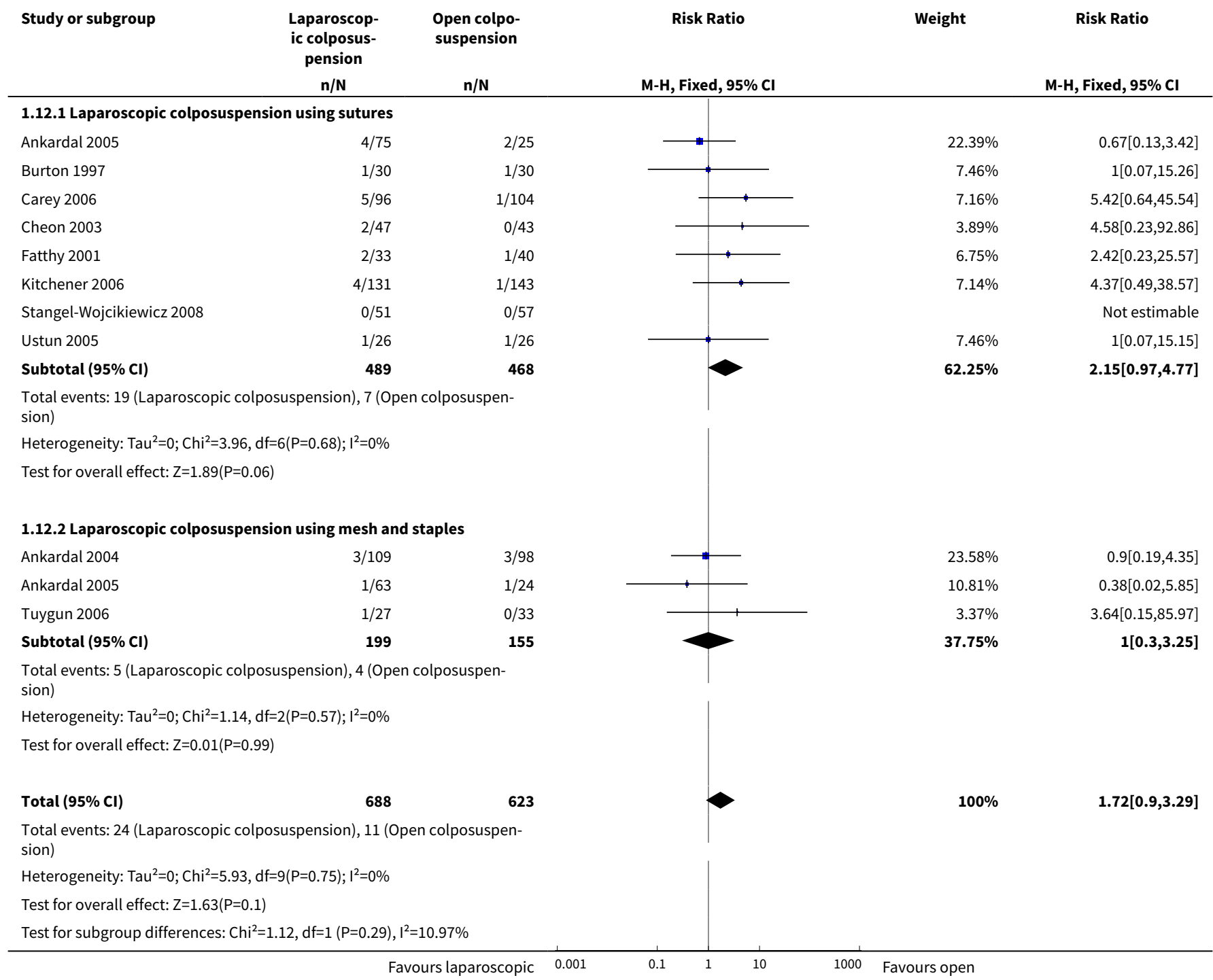

Analysis 1.13. Comparison 1 Laparoscopic colposuspension versus open colposuspension, Outcome 13 De novo detrusor overactivity (urodynamic diagnosis).

Study or subgroup

$\begin{array}{ll}\text { Laparoscop- } & \text { Open colpo- } \\ \text { ic colposus- } & \text { suspension } \\ \text { pension } & \end{array}$

Risk Ratio

Weight

Risk Ratio

$n / N$

$\mathrm{n} / \mathbf{N}$

M-H, Fixed, $95 \% \mathrm{Cl}$

M-H, Fixed, $95 \% \mathrm{Cl}$

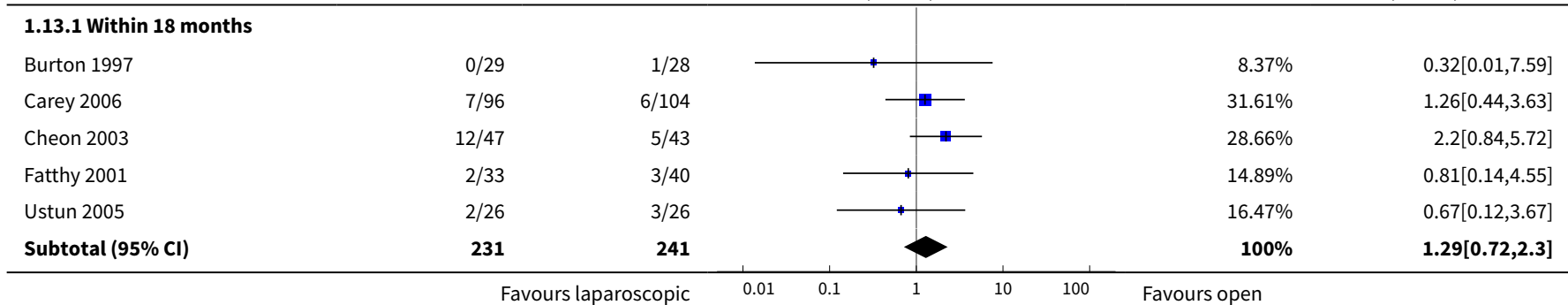

Laparoscopic colposuspension for urinary incontinence in women (Review) 


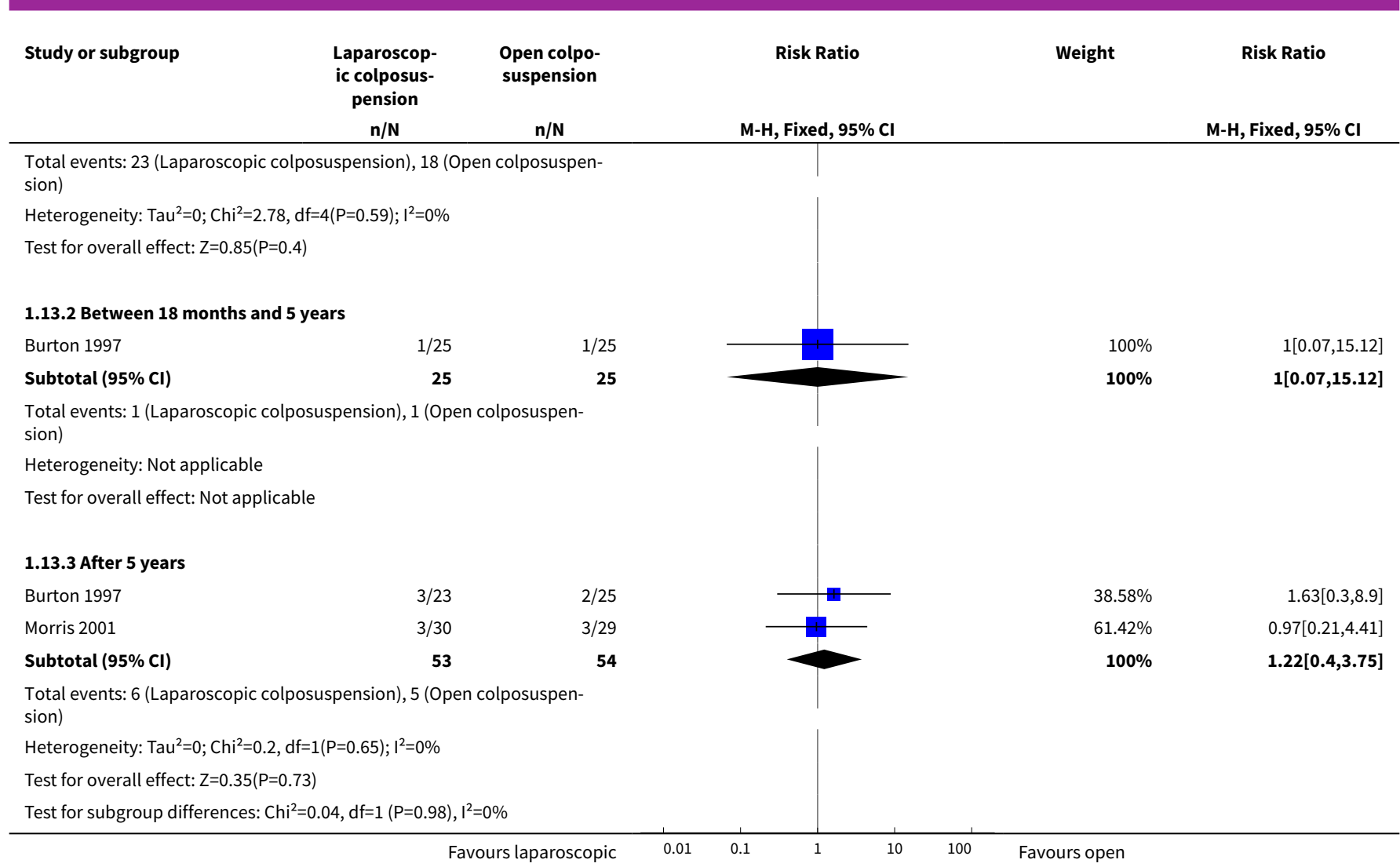

\section{Analysis 1.14. Comparison 1 Laparoscopic colposuspension versus open colposuspension, Outcome 14 Voiding dysfunction within 18 months.}

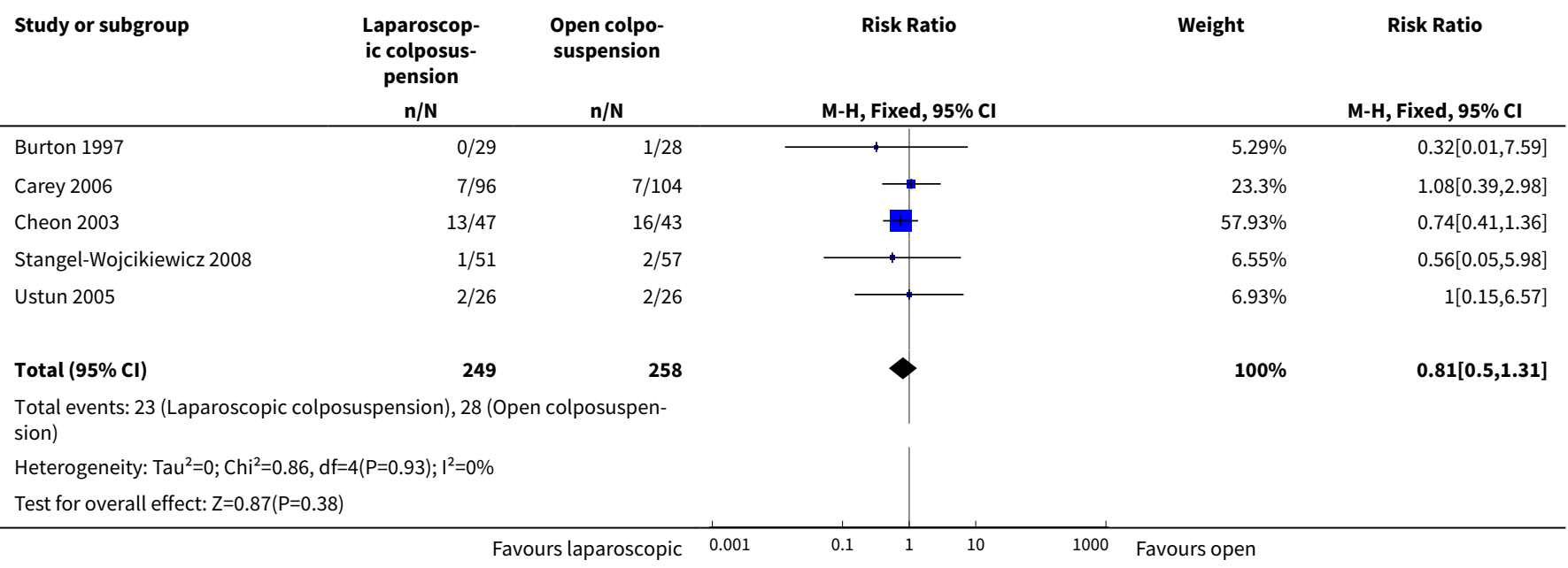




\section{Analysis 1.15. Comparison 1 Laparoscopic colposuspension} versus open colposuspension, Outcome 15 Quality of life.

\begin{tabular}{|c|c|c|c|c|c|c|c|}
\hline \multirow[t]{2}{*}{ Study or subgroup } & \multicolumn{2}{|c|}{$\begin{array}{l}\text { Laparoscopic col- } \\
\text { posuspension }\end{array}$} & \multicolumn{2}{|c|}{$\begin{array}{l}\text { Open colpo- } \\
\text { suspension }\end{array}$} & \multirow{2}{*}{$\begin{array}{c}\text { Std. Mean Difference } \\
\text { Random, 95\% Cl } \\
\end{array}$} & \multirow[t]{2}{*}{ Weight } & \multirow{2}{*}{$\begin{array}{l}\text { Std. Mean Difference } \\
\text { Random, } 95 \% \mathrm{Cl} \\
\end{array}$} \\
\hline & $\mathbf{N}$ & Mean(SD) & $\mathbf{N}$ & Mean(SD) & & & \\
\hline \multicolumn{8}{|c|}{ 1.15.1 EQ-5D and SUDI } \\
\hline Carey 2006 & 96 & $23.9(17.9)$ & 104 & $21.6(16.9)$ & \pm & $40.66 \%$ & $0.14[-0.14,0.41]$ \\
\hline Kitchener 2006 & 144 & $0.8(0.3)$ & 147 & $0.8(0.3)$ & & $59.34 \%$ & $0.07[-0.16,0.3]$ \\
\hline Subtotal $\star \star \star$ & 240 & & 251 & & & $100 \%$ & $0.1[-0.08,0.27]$ \\
\hline \multicolumn{8}{|c|}{ Test for overall effect: $Z=1.08(P=0.28)$} \\
\hline \multicolumn{8}{|c|}{ 1.15.2 EQ-5D and SIIQ } \\
\hline Carey 2006 & 96 & $31.4(23.8)$ & 104 & $26.9(29.4)$ & $\Phi$ & $40.63 \%$ & $0.17[-0.11,0.45]$ \\
\hline Kitchener 2006 & 144 & $0.8(0.3)$ & 147 & $0.8(0.3)$ & & $59.37 \%$ & $0.07[-0.16,0.3]$ \\
\hline Subtotal $\star \star \star$ & 240 & & 251 & & 1 & $100 \%$ & $0.11[-0.07,0.29]$ \\
\hline \multicolumn{8}{|c|}{ Test for overall effect: $\mathrm{Z}=1.23(\mathrm{P}=0.22)$} \\
\hline Test for subgroup dif & $01, \mathrm{df}=$ & $P=0.92), I^{2}=0 \%$ & & & & & \\
\hline
\end{tabular}

\section{Comparison 2. Laparoscopic colposuspension versus midurethral sling procedures}

\begin{tabular}{|c|c|c|c|c|}
\hline Outcome or subgroup title & $\begin{array}{l}\text { No. of } \\
\text { studies }\end{array}$ & $\begin{array}{l}\text { No. of } \\
\text { partici- } \\
\text { pants }\end{array}$ & Statistical method & Effect size \\
\hline 1 Subjective cure within 18 months & 5 & 377 & Risk Ratio (M-H, Fixed, 95\% Cl) & $0.91[0.80,1.02]$ \\
\hline $\begin{array}{l}\text { 1.1 Laparoscopic colposuspension us- } \\
\text { ing sutures vs TVT }\end{array}$ & 4 & 256 & Risk Ratio (M-H, Fixed, 95\% Cl) & $1.01[0.88,1.16]$ \\
\hline $\begin{array}{l}\text { 1.2 Laparoscopic colposuspension us- } \\
\text { ing mesh vs TVT }\end{array}$ & 1 & 121 & Risk Ratio (M-H, Fixed, 95\% Cl) & $0.71[0.55,0.91]$ \\
\hline $\begin{array}{l}2 \text { Number of women with de novo ur- } \\
\text { gency symptoms }\end{array}$ & 2 & 201 & Risk Ratio (M-H, Fixed, 95\% Cl) & $0.44[0.13,1.47]$ \\
\hline 3 Incontinence episodes per week & 2 & 150 & Mean Difference (IV, Fixed, 95\% CI) & $-1.40[-2.07,-0.73]$ \\
\hline $\begin{array}{l}\text { 3.1 Laparoscopic colposuspension us- } \\
\text { ing sutures vs TVT }\end{array}$ & 1 & 63 & Mean Difference (IV, Fixed, 95\% CI) & $-1.4[-3.30,0.50]$ \\
\hline $\begin{array}{l}3.2 \text { Laparoscopic colposuspension us- } \\
\text { ing sutures vs SPARC sling }\end{array}$ & 1 & 87 & Mean Difference (IV, Fixed, 95\% CI) & $-1.4[-2.12,-0.68]$ \\
\hline 4 Objective cure within 18 months & 7 & 575 & Risk Ratio (M-H, Fixed, 95\% Cl) & $0.88[0.81,0.95]$ \\
\hline $\begin{array}{l}\text { 4.1 Laparoscopic colposuspension us- } \\
\text { ing sutures vs TVT }\end{array}$ & 6 & 454 & Risk Ratio (M-H, Fixed, 95\% Cl) & $0.93[0.86,1.01]$ \\
\hline $\begin{array}{l}\text { 4.2 Laparoscopic colposuspension us- } \\
\text { ing mesh vs TVT }\end{array}$ & 1 & 121 & Risk Ratio (M-H, Fixed, 95\% Cl) & $0.66[0.51,0.86]$ \\
\hline
\end{tabular}




\begin{tabular}{|c|c|c|c|c|}
\hline Outcome or subgroup title & $\begin{array}{l}\text { No. of } \\
\text { studies }\end{array}$ & $\begin{array}{l}\text { No. of } \\
\text { partici- } \\
\text { pants }\end{array}$ & Statistical method & Effect size \\
\hline 5 Length of inpatient stay (days) & 5 & 322 & Mean Difference (IV, Fixed, 95\% CI) & $1.18[0.82,1.55]$ \\
\hline $\begin{array}{l}6 \text { Time to return to daily activities } \\
\text { (days) }\end{array}$ & 3 & 280 & Mean Difference (IV, Fixed, 95\% CI) & $7.14[4.60,9.67]$ \\
\hline 7 Operation time (mins) & 6 & 392 & Mean Difference (IV, Random, 95\% CI) & $25.85[13.56,38.13]$ \\
\hline $\begin{array}{l}8 \text { Perioperative complications (number } \\
\text { of events) }\end{array}$ & 7 & 514 & Risk Ratio (M-H, Fixed, 95\% Cl) & $0.99[0.60,1.64]$ \\
\hline $\begin{array}{l}8.1 \text { Laparoscopic colposuspension us- } \\
\text { ing sutures vs TVT }\end{array}$ & 6 & 393 & Risk Ratio (M-H, Fixed, 95\% Cl) & $0.81[0.46,1.45]$ \\
\hline $\begin{array}{l}8.2 \text { Laparoscopic colposuspension us- } \\
\text { ing mesh vs TVT }\end{array}$ & 1 & 121 & Risk Ratio (M-H, Fixed, 95\% Cl) & $1.92[0.65,5.71]$ \\
\hline $\begin{array}{l}9 \text { De novo detrusor overactivity (urody- } \\
\text { namic diagnosis) within } 18 \text { months }\end{array}$ & 4 & 326 & Risk Ratio (M-H, Fixed, 95\% Cl) & $0.80[0.34,1.88]$ \\
\hline $\begin{array}{l}\text { 9.1 Laparoscopic colposuspension us- } \\
\text { ing sutures vs TVT }\end{array}$ & 4 & 326 & Risk Ratio (M-H, Fixed, 95\% Cl) & $0.80[0.34,1.88]$ \\
\hline $\begin{array}{l}10 \text { Voiding dysfunction within } 18 \\
\text { months }\end{array}$ & 5 & 412 & Risk Ratio (M-H, Fixed, 95\% Cl) & $1.06[0.47,2.41]$ \\
\hline $\begin{array}{l}10.1 \text { Laparoscopic colposuspension us- } \\
\text { ing sutures vs TVT }\end{array}$ & 4 & 291 & Risk Ratio (M-H, Fixed, 95\% Cl) & $1.00[0.41,2.48]$ \\
\hline $\begin{array}{l}\text { 10.2 Laparoscopic colposuspension us- } \\
\text { ing mesh vs TVT }\end{array}$ & 1 & 121 & Risk Ratio (M-H, Fixed, 95\% Cl) & $1.37[0.20,9.42]$ \\
\hline
\end{tabular}

Analysis 2.1. Comparison 2 Laparoscopic colposuspension versus midurethral sling procedures, Outcome 1 Subjective cure within 18 months.

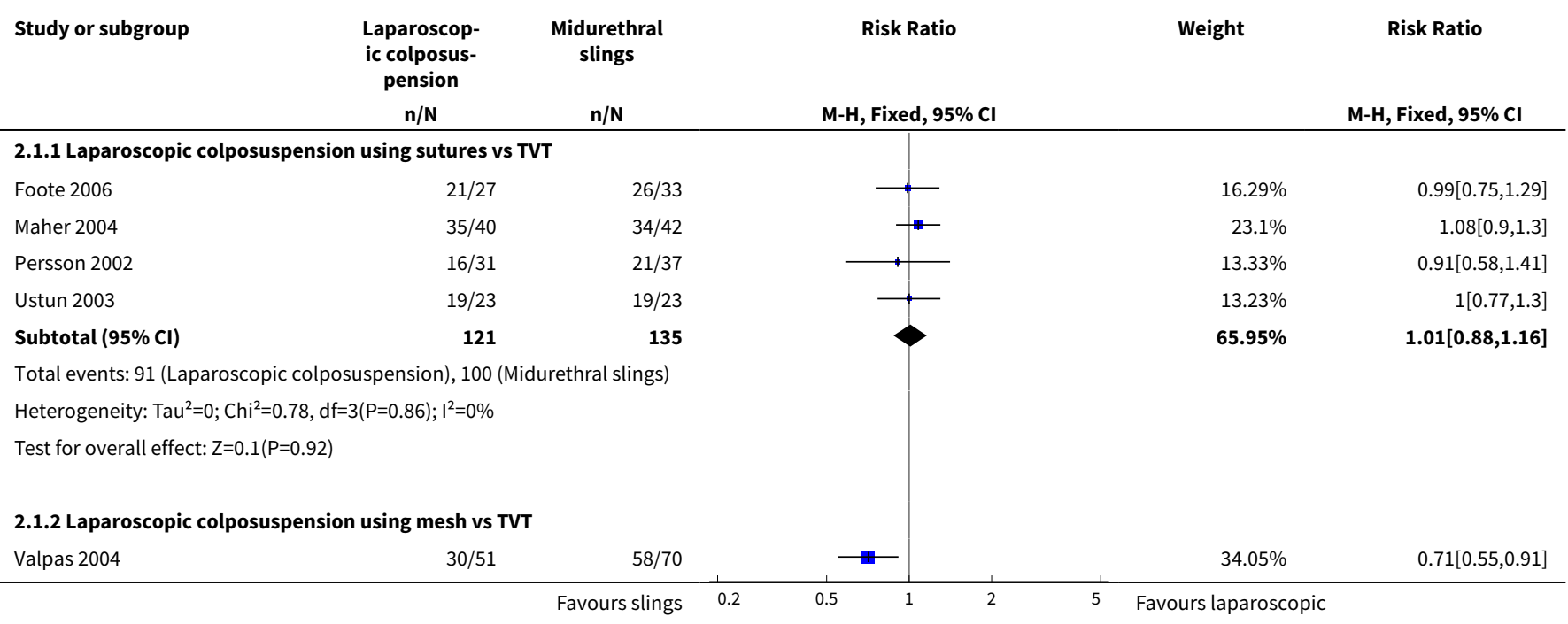




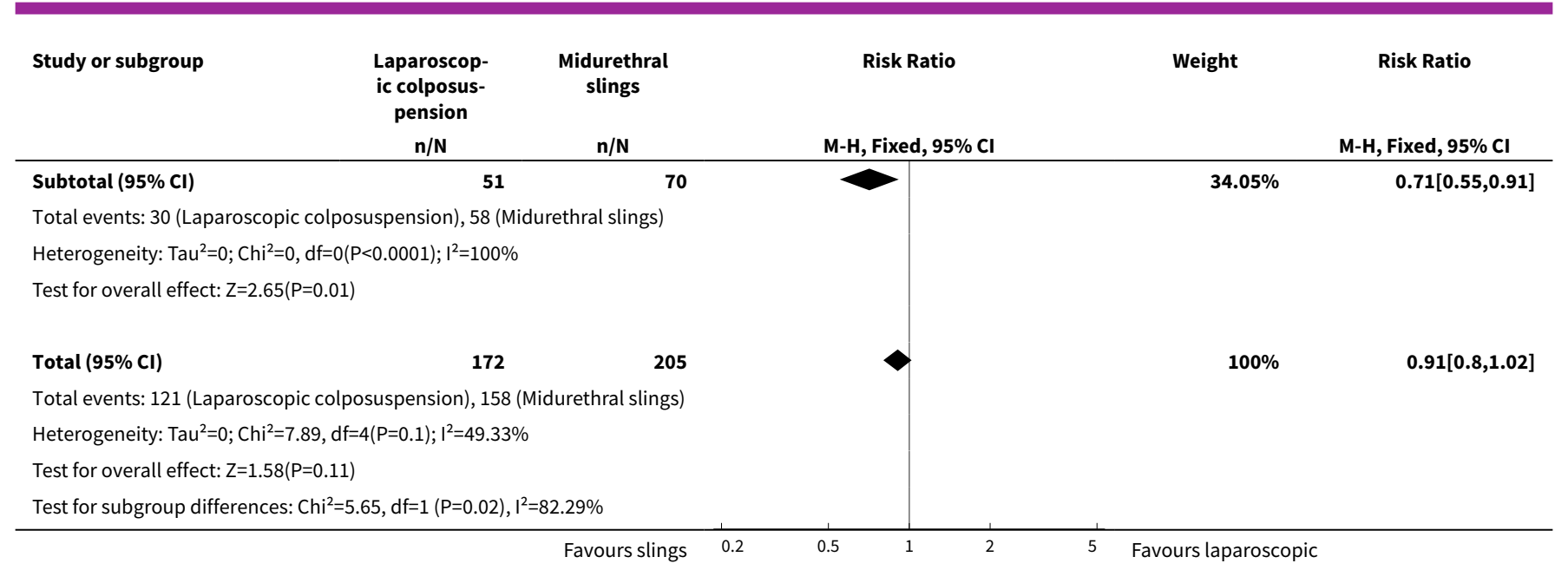

Analysis 2.2. Comparison 2 Laparoscopic colposuspension versus midurethral sling procedures, Outcome 2 Number of women with de novo urgency symptoms.

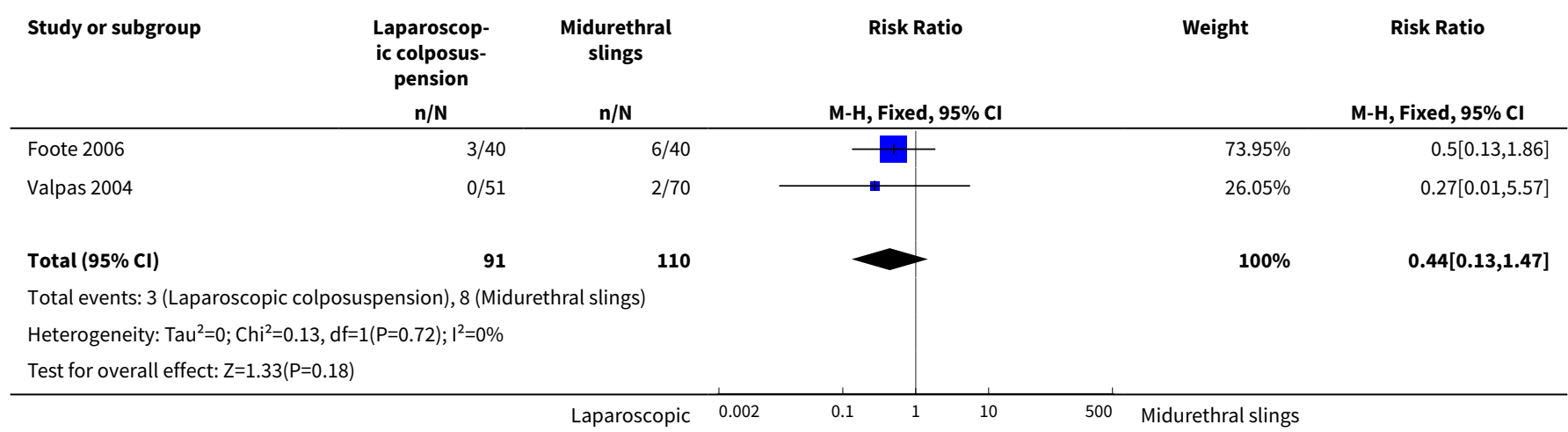

Analysis 2.3. Comparison 2 Laparoscopic colposuspension versus midurethral sling procedures, Outcome 3 Incontinence episodes per week.

\begin{tabular}{|c|c|c|c|c|c|c|c|}
\hline \multirow[t]{2}{*}{ Study or subgroup } & \multicolumn{2}{|c|}{$\begin{array}{l}\text { Laparoscopic col- } \\
\text { posuspension }\end{array}$} & \multicolumn{2}{|c|}{ Midurethral slings } & \multirow{2}{*}{$\begin{array}{c}\text { Mean Difference } \\
\text { Fixed, } 95 \% \mathrm{Cl} \\
\end{array}$} & \multirow[t]{2}{*}{ Weight } & \multirow{2}{*}{$\begin{array}{l}\text { Mean Difference } \\
\text { Fixed, } 95 \% \mathrm{Cl}\end{array}$} \\
\hline & $\mathbf{N}$ & Mean(SD) & $\mathbf{N}$ & Mean(SD) & & & \\
\hline \multicolumn{8}{|c|}{ 2.3.1 Laparoscopic colposuspension using sutures vs TVT } \\
\hline Paraiso 2004 & 33 & $0.4(1.6)$ & 30 & $1.8(5.1)$ & - & $12.45 \%$ & $-1.4[-3.3,0.5]$ \\
\hline Subtotal $\star \star \star$ & 33 & & 30 & & & $12.45 \%$ & $-1.4[-3.3,0.5]$ \\
\hline \multicolumn{8}{|c|}{ Heterogeneity: Not applicable } \\
\hline \multicolumn{8}{|c|}{ 2.3.2 Laparoscopic colposuspension using sutures vs SPARC sling } \\
\hline Foote 2006 & 43 & $2.1(1.5)$ & 44 & $3.5(1.9)$ & - & $87.55 \%$ & $-1.4[-2.12,-0.68]$ \\
\hline 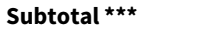 & 43 & & 44 & & & $87.55 \%$ & $-1.4[-2.12,-0.68]$ \\
\hline \multicolumn{8}{|c|}{ Heterogeneity: Not applicable } \\
\hline \multicolumn{8}{|c|}{ Test for overall effect: $\mathrm{Z}=3.82(\mathrm{P}=0)$} \\
\hline & & & Favour & roscopic & -1 & Favours & \\
\hline
\end{tabular}




\begin{tabular}{|c|c|c|c|c|c|c|c|}
\hline \multirow{3}{*}{ 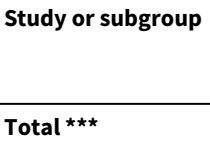 } & \multicolumn{2}{|c|}{$\begin{array}{l}\text { Laparoscopic col- } \\
\text { posuspension }\end{array}$} & \multicolumn{2}{|c|}{ Midurethral slings } & \multirow{2}{*}{$\begin{array}{c}\text { Mean Difference } \\
\text { Fixed, } 95 \% \mathrm{Cl} \\
\end{array}$} & \multirow{3}{*}{$\begin{array}{r}\text { Weight } \\
100 \%\end{array}$} & \multirow{3}{*}{$\begin{array}{l}\text { Mean Difference } \\
\text { Fixed, 95\% Cl } \\
-1.4[-2.07,-0.73]\end{array}$} \\
\hline & \multirow{2}{*}{$\frac{N}{76}$} & \multirow[t]{2}{*}{ Mean(SD) } & & \multirow[t]{2}{*}{ Mean(SD) } & & & \\
\hline & & & & & & & \\
\hline \multicolumn{8}{|c|}{ Heterogeneity: $\operatorname{Tau}^{2}=0 ; \mathrm{Chi}^{2}=0, \mathrm{df}=1(\mathrm{P}=1) ;\left.\right|^{2}=0 \%$} \\
\hline \multicolumn{8}{|c|}{ Test for overall effect: $Z=4.08(P<0.0001)$} \\
\hline
\end{tabular}

Favours laparoscopic

Analysis 2.4. Comparison 2 Laparoscopic colposuspension versus midurethral sling procedures, Outcome 4 Objective cure within 18 months.

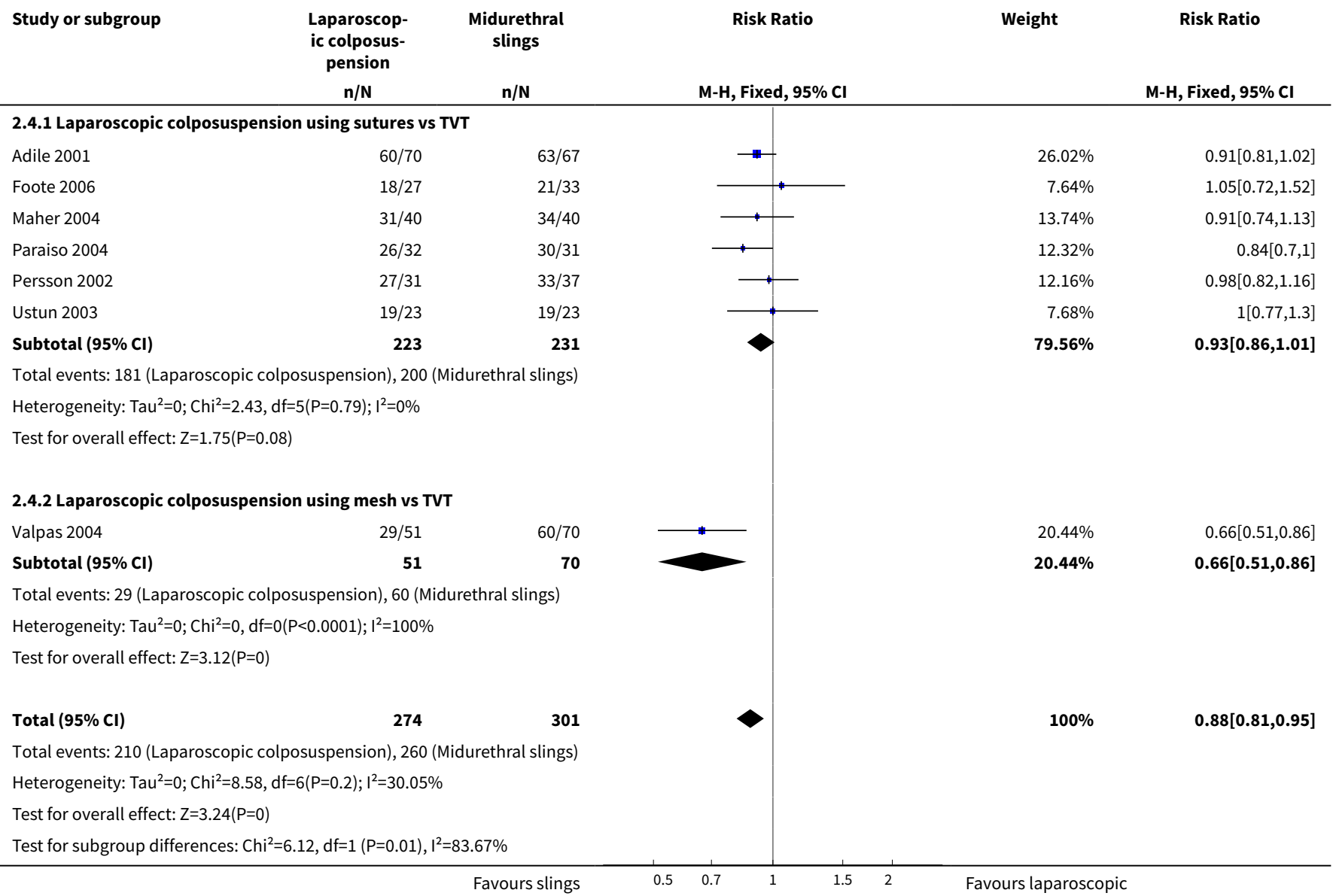

Analysis 2.5. Comparison 2 Laparoscopic colposuspension versus midurethral sling procedures, Outcome 5 Length of inpatient stay (days).

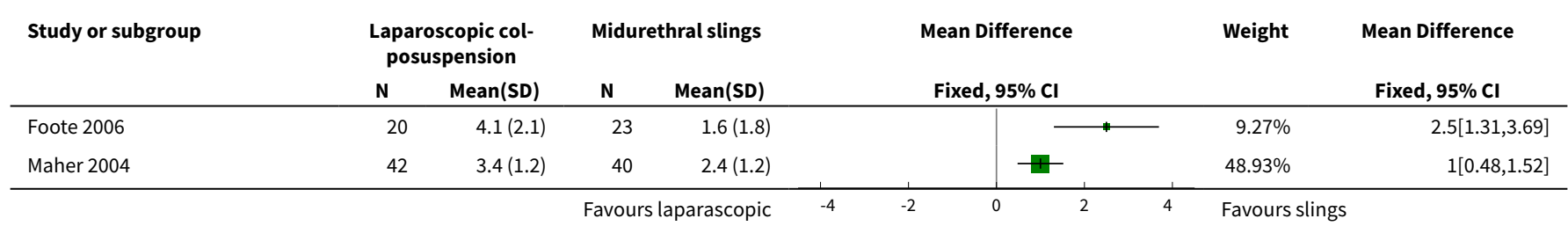




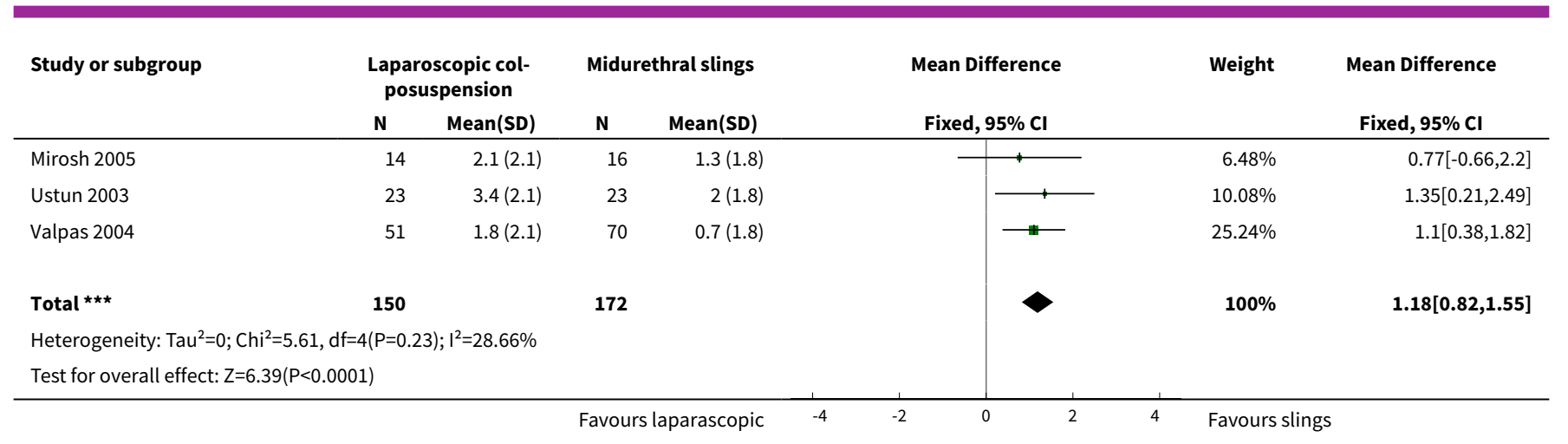

Analysis 2.6. Comparison 2 Laparoscopic colposuspension versus midurethral sling procedures, Outcome 6 Time to return to daily activities (days).

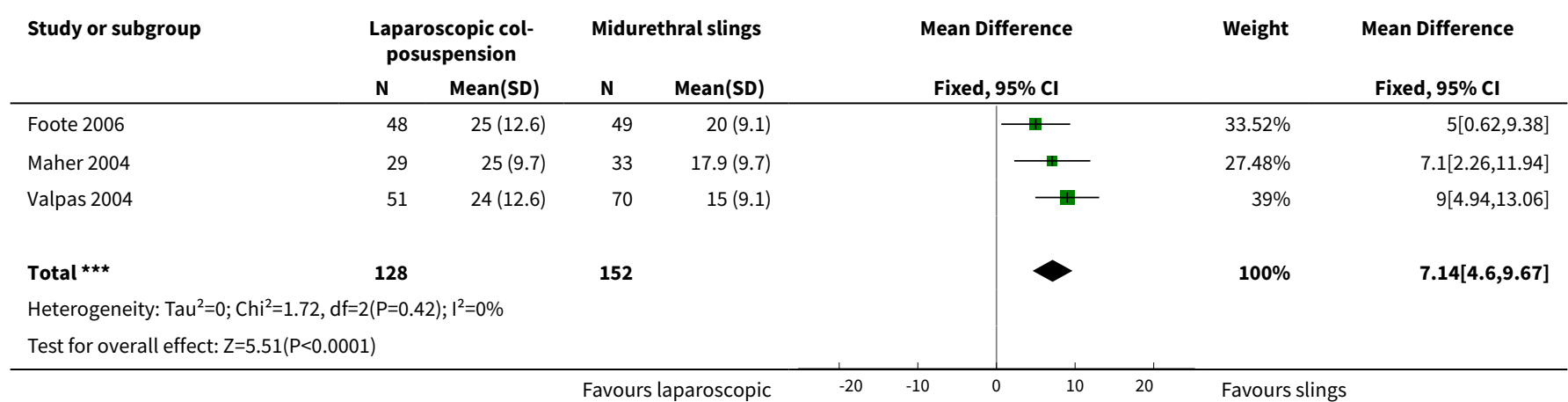

Analysis 2.7. Comparison 2 Laparoscopic colposuspension versus midurethral sling procedures, Outcome 7 Operation time (mins).

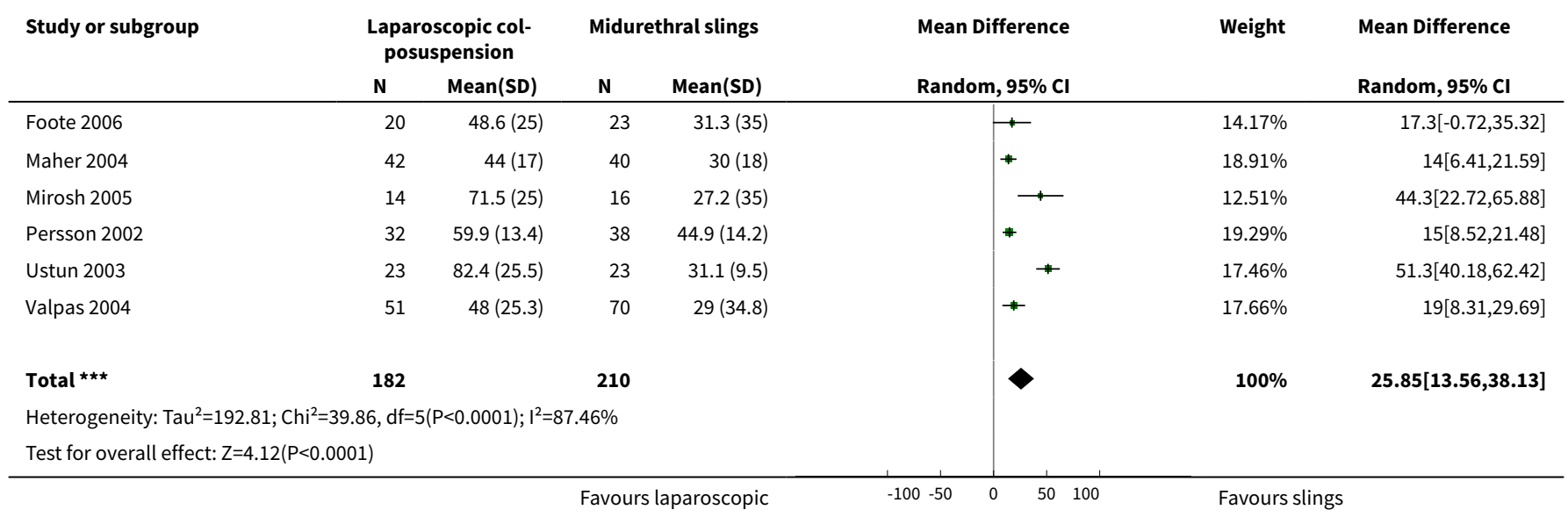


Analysis 2.8. Comparison 2 Laparoscopic colposuspension versus midurethral sling procedures, Outcome 8 Perioperative complications (number of events).

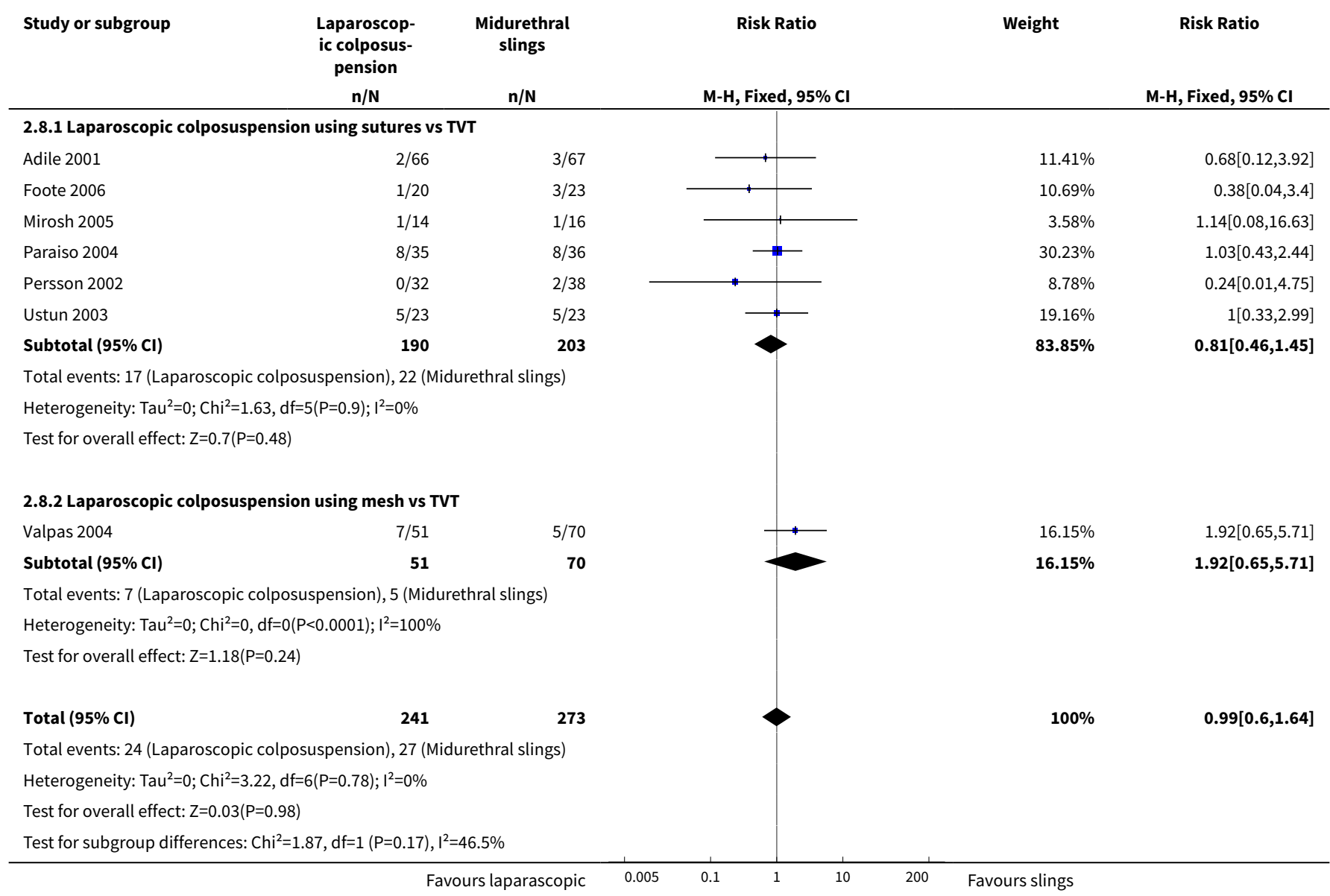

Analysis 2.9. Comparison 2 Laparoscopic colposuspension versus midurethral sling procedures, Outcome 9 De novo detrusor overactivity (urodynamic diagnosis) within 18 months.

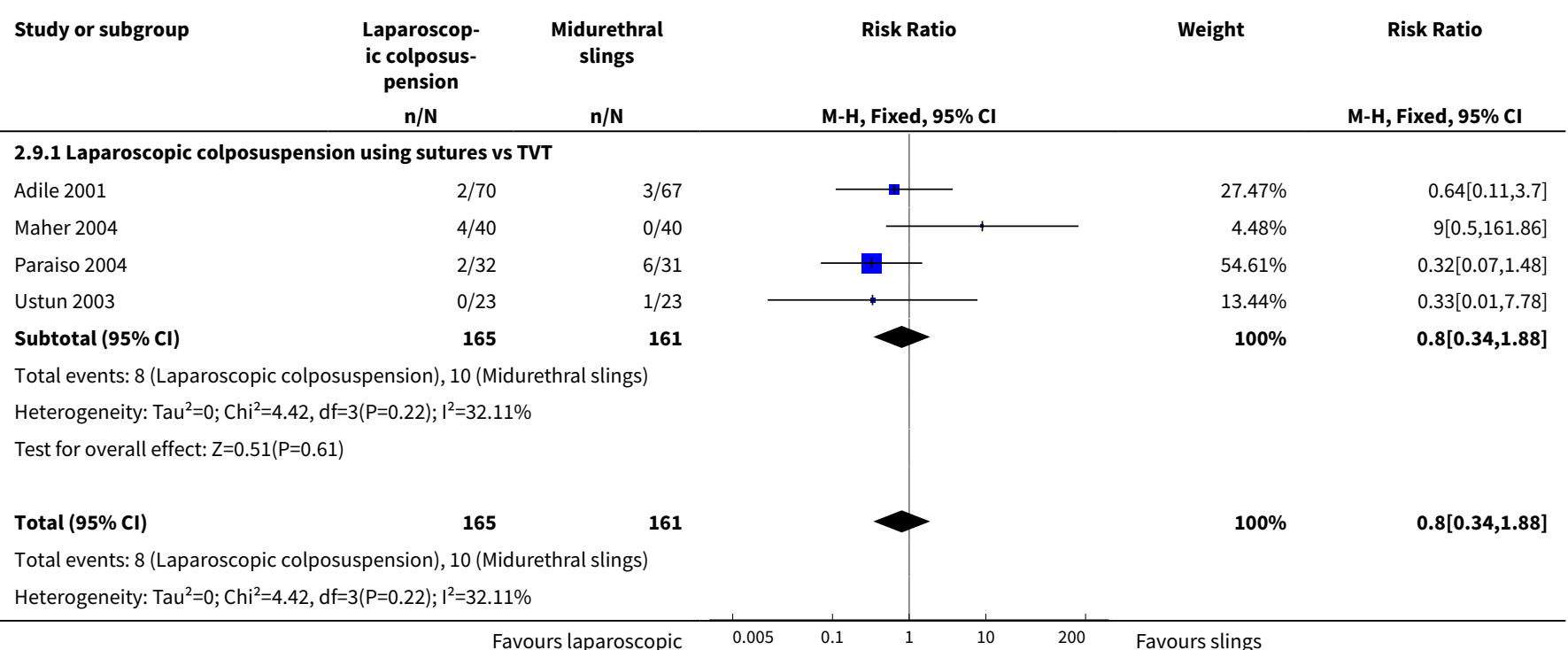




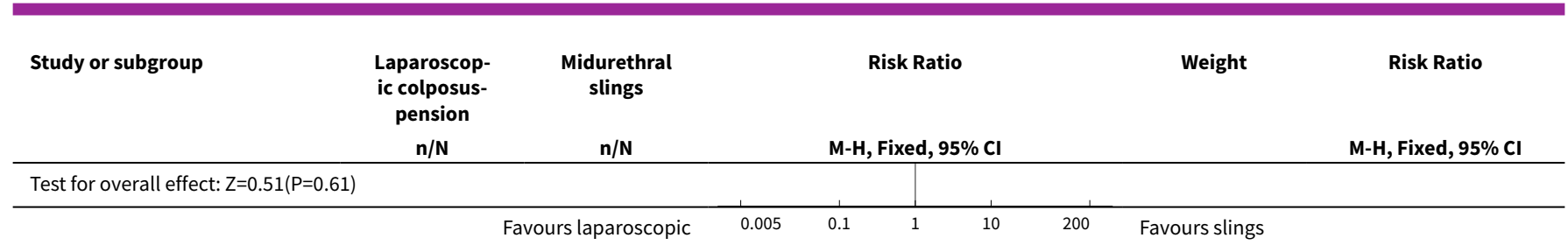

Analysis 2.10. Comparison 2 Laparoscopic colposuspension versus midurethral sling procedures, Outcome 10 Voiding dysfunction within 18 months.

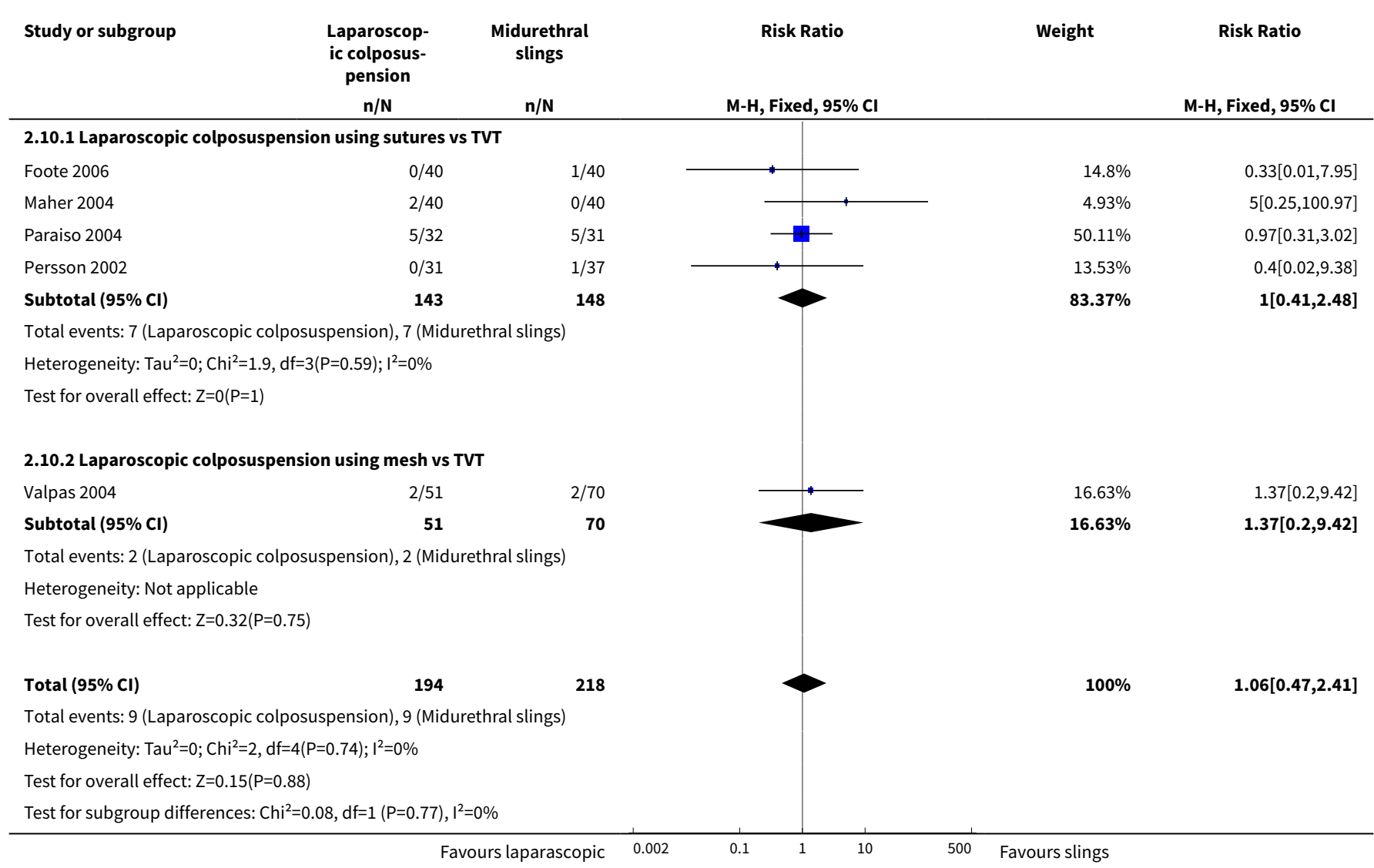

\section{Comparison 3. Laparoscopic colposuspension with sutures versus laparoscopic colposuspension with mesh and} staples

\begin{tabular}{llllll}
\hline Outcome or subgroup title & $\begin{array}{l}\text { No. of } \\
\text { studies }\end{array}$ & $\begin{array}{l}\text { No. of } \\
\text { partici- } \\
\text { pants }\end{array}$ & Statistical method & Effect size \\
\hline 1 Subjective cure within 18 months & 2 & 180 & Risk Ratio (M-H, Fixed, 95\% Cl) & $1.28[1.11,1.47]$ \\
\hline 2 Objective cure within 18 months & 3 & 243 & Risk Ratio (M-H, Random, 95\% Cl) & $1.17[0.89,1.55]$ \\
\hline 3 Perioperative complications & 3 & 260 & Risk Ratio (M-H, Fixed, 95\% Cl) & $1.94[1.09,3.48]$ \\
\hline
\end{tabular}




\begin{tabular}{lllll}
\hline Outcome or subgroup title & $\begin{array}{l}\text { No. of } \\
\text { studies }\end{array}$ & $\begin{array}{l}\text { No. of } \\
\text { partici- } \\
\text { pants }\end{array}$ & Statistical method & Effect size \\
\hline $\begin{array}{l}\text { 4 De novo detrusor overactivity } \\
\text { within } 18 \text { months }\end{array}$ & 2 & 122 & Risk Ratio (M-H, Fixed, 95\% Cl) & $0.72[0.17,3.06]$ \\
\hline
\end{tabular}

Analysis 3.1. Comparison 3 Laparoscopic colposuspension with sutures versus laparoscopic colposuspension with mesh and staples, Outcome 1 Subjective cure within 18 months.

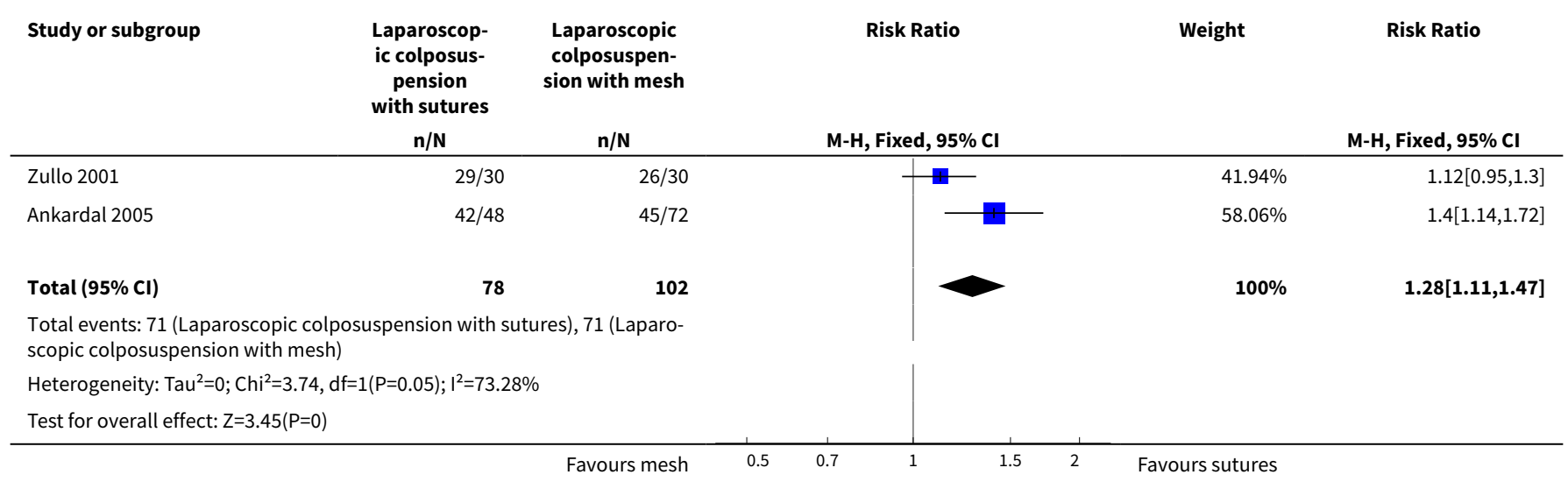

\section{Analysis 3.2. Comparison 3 Laparoscopic colposuspension with sutures versus laparoscopic} colposuspension with mesh and staples, Outcome 2 Objective cure within 18 months.

\begin{tabular}{|c|c|c|c|c|c|}
\hline Study or subgroup & $\begin{array}{l}\text { Laparoscop- } \\
\text { ic colposus- } \\
\text { pension } \\
\text { with sutures }\end{array}$ & $\begin{array}{l}\text { Laparoscopic } \\
\text { colposuspen- } \\
\text { sion with mesh }\end{array}$ & M-H, Random, $95 \% \mathrm{Cl}$ & Weight & $\begin{array}{c}\text { Risk Ratio } \\
\text { M-H, Random, } 95 \% \mathrm{Cl}\end{array}$ \\
\hline Ankardal 2005 & $43 / 48$ & $44 / 70$ & $\longrightarrow$ & $32.95 \%$ & $1.43[1.16,1.75]$ \\
\hline Ross 1996 & $32 / 35$ & $32 / 34$ & - & $36.7 \%$ & $0.97[0.85,1.11]$ \\
\hline Zullo 2001 & $25 / 28$ & $21 / 28$ & —- & $30.35 \%$ & $1.19[0.93,1.53]$ \\
\hline Total $(95 \% \mathrm{Cl})$ & 111 & 132 & & $100 \%$ & $1.17[0.89,1.55]$ \\
\hline \multicolumn{6}{|c|}{$\begin{array}{l}\text { Total events: } 100 \text { (Laparoscopic colposuspension with sutures), } 97 \text { (La- } \\
\text { paroscopic colposuspension with mesh) }\end{array}$} \\
\hline \multicolumn{6}{|c|}{ Heterogeneity: $\mathrm{Tau}^{2}=0.05 ; \mathrm{Chi}^{2}=12.88, \mathrm{df}=2(\mathrm{P}=0) ; \mathrm{I}^{2}=84.47 \%$} \\
\hline \multicolumn{6}{|c|}{ Test for overall effect: $Z=1.11(P=0.27)$} \\
\hline
\end{tabular}


Analysis 3.3. Comparison 3 Laparoscopic colposuspension with sutures versus laparoscopic colposuspension with mesh and staples, Outcome 3 Perioperative complications.

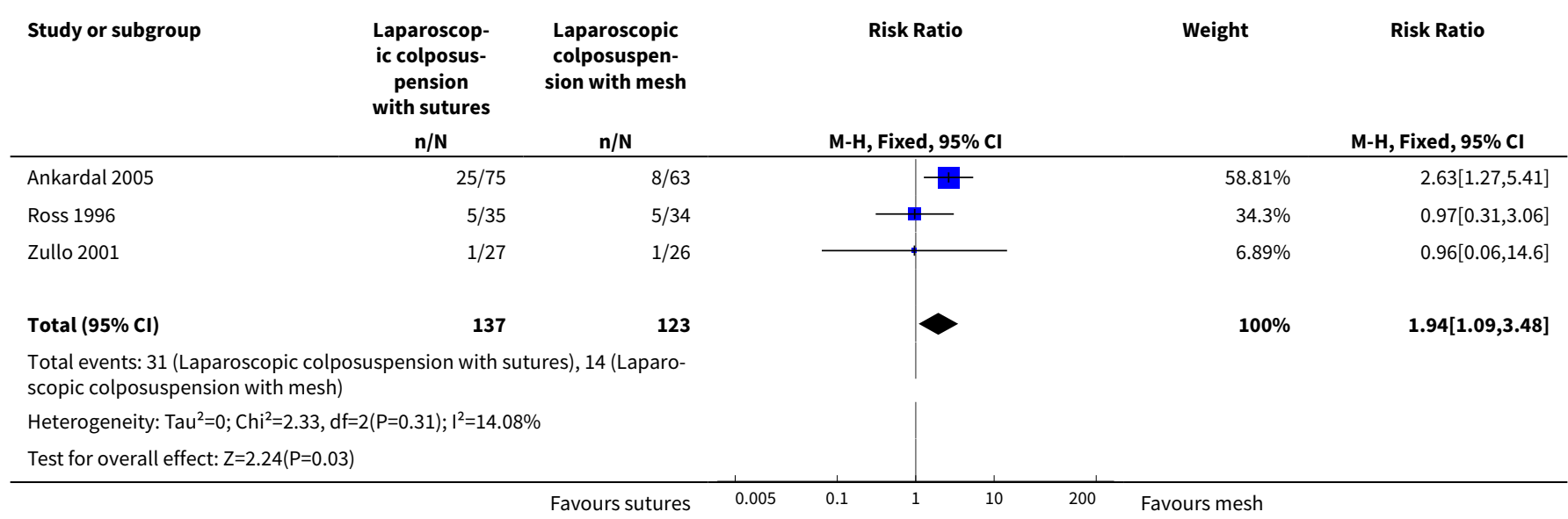

Analysis 3.4. Comparison 3 Laparoscopic colposuspension with sutures versus laparoscopic colposuspension with mesh and staples, Outcome 4 De novo detrusor overactivity within 18 months.

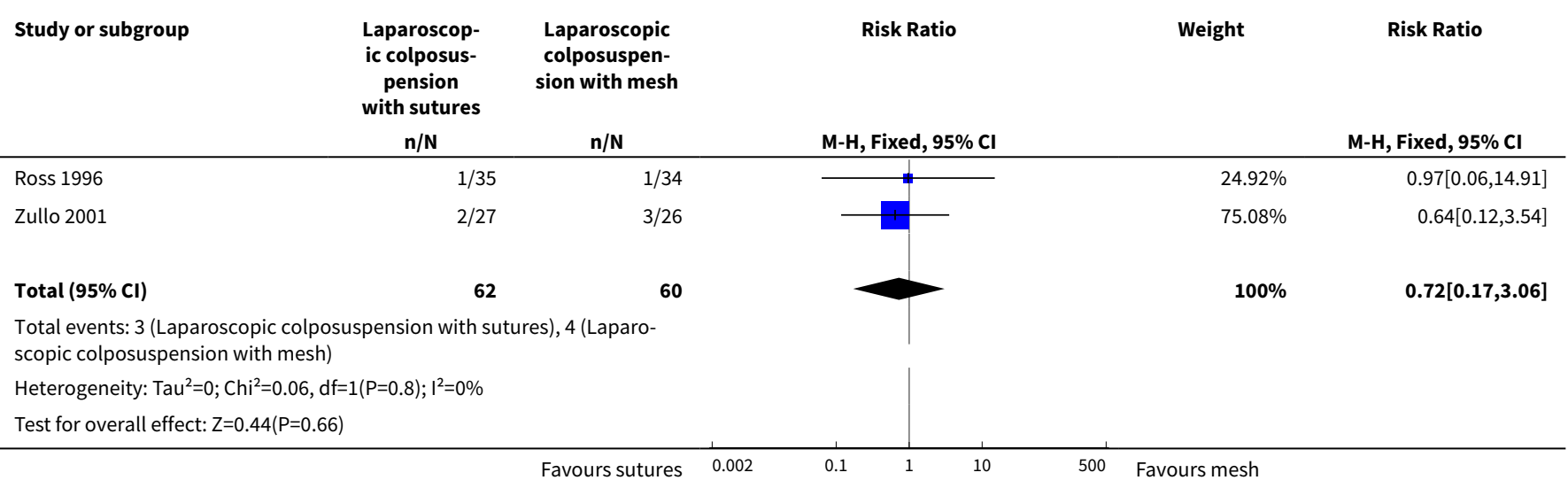

\section{ADDITIONAL TABLES}

Table 1. Additional data: laparoscopic colposuspension versus open colposuspension

\begin{tabular}{llll}
\hline Laparoscopic colposuspension versus open colposuspension & & \\
\hline Study & Outcome & Laparoscopic & Open \\
\hline $\begin{array}{lll}\text { Ankardal } \\
2004\end{array}$ & VAS scores (median, range): & $1(0-47)$ & $0(0-4)$ \\
& Physical activity & $0(0-13)$ & $0(0-0)$ \\
& Working ability & $0(0-20)$ & $0(0-0)$ \\
& Social life & $0(0-10)$ &
\end{tabular}


Table 1. Additional data: laparoscopic colposuspension versus open colposuspension (Continued)

\begin{tabular}{|c|c|c|c|}
\hline \multirow{10}{*}{$\begin{array}{l}\text { Ankardal } \\
2005\end{array}$} & VAS scores (median, range): & (mesh) & $0(0-2)$ \\
\hline & Physical activity & $2(0-44)$ & $0(0-0)$ \\
\hline & Working ability & $0(0-16)$ & $0(0-0)$ \\
\hline & Social life & $0(0-20)$ & $0(0-0)$ \\
\hline & Sexual life & $0(0-18)$ & \\
\hline & VAS scores (median, range): & (sutures) & $0(0-2)$ \\
\hline & Physical activity & $0(0-0)$ & $0(0-0)$ \\
\hline & Working ability & $0(0-0)$ & $0(0-0)$ \\
\hline & Social life & $0(0-0)$ & $0(0-0)$ \\
\hline & Sexual life & $0(0-0)$ & \\
\hline \multirow[t]{3}{*}{ Carey 2006} & SF-36 General Health (mean, SD) ${ }^{a}$ & $2.60(1.02)$ & $2.22(1.06)$ \\
\hline & SUDI (mean, SD)b & $23.92(17.90)$ & $21.56(16.92)$ \\
\hline & SIIQb & $31.40(23.83)$ & $26.87(29.36)$ \\
\hline \multirow[t]{2}{*}{ Cheon 2003} & VAS scores (mean, SD): & $22.2(15.9)$ & $29.3(19.8)$ \\
\hline & Return to normal activity (days) & & \\
\hline \multirow{5}{*}{$\begin{array}{l}\text { Kitchener } \\
2006\end{array}$} & SF-36 (mean, SD): physical subscale $a$ & $79.32(27.59)$ & $77.60(27.74)$ \\
\hline & SF-36 (mean, SD): mental subscale $a$ & $69.51(21.21)$ & $69.38(22.65)$ \\
\hline & EQ-5D (mean, SD)b & $0.844(0.259)$ & $0.825(0.270)$ \\
\hline & Mean (SD) total costs & GBP 1805 (471) & GBP 1433 (362) \\
\hline & QALYs at 2 years (mean) & 1.677 & 1.637 \\
\hline
\end{tabular}

EQ-5D: EuroQuol generic health questionnaire; QALY: quality-adjusted life years; SD: standard deviation; SF-36: short-form 36 item health survey; SIIQ: Short Incontinence Impact Questionnaire; SUDI: Short Urinary Distress Inventory; VAS: visual analogue scale

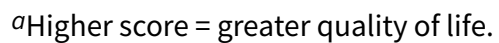

bLower score $=$ greater quality of life.

Table 2. Additional data: laparoscopic colposuspension versus midurethral slings

\begin{tabular}{|c|c|c|c|}
\hline Study & Outcome & Laparoscopic colposuspension & Midurethral slings \\
\hline \multicolumn{4}{|c|}{ Quality of life } \\
\hline Foote 2006 & YQ and UDI & \multicolumn{2}{|c|}{ No evidence of a difference between groups } \\
\hline Maher 2004 & SUDI, SIIQ, SF-36 & \multicolumn{2}{|c|}{ No evidence of a difference between groups } \\
\hline
\end{tabular}


Table 2. Additional data: laparoscopic colposuspension versus midurethral slings (Continued)
Mirosh 2005
SF-36 to assess quality of life. Symptom
No evidence of a difference between groups distress for urinary incontinence in women with the IIQ and the UDI

\begin{tabular}{lll}
\hline Paraiso 2004 & UDI-6 and IIQ-7 & No evidence of a difference between groups \\
\hline Samiee 2009 & SUDI, SIIQ, SF-36 & No significant difference between the two groups \\
\cline { 2 - 3 } & $\begin{array}{l}\text { SF-36 to assess quality of life. Symptom } \\
\text { distress for urinary incontinence in women } \\
\text { with the IIQ and the UDI }\end{array}$ & No evidence of a difference between groups \\
\cline { 2 - 3 } & \\
\cline { 2 - 3 } UDI-6 and IIQ-7 & No evidence of a difference between groups \\
\hline I-QOL, UDI-6 and ISI & $\begin{array}{l}\text { I-QOL: "significantly increased in both groups after } 6 \text { months of opera- } \\
\text { tion ( } \mathrm{p}<0.05) \text {. But the differences were not statistically significant". }\end{array}$ \\
& $\begin{array}{l}\text { UDI-6: improvement in urgency was significant in TOT compared to } \\
\text { Burch (P = 0.04) } \\
\text { ISI: subjective cure rate following surgery showing no evidence of a } \\
\text { difference between groups }(P=0.23)\end{array}$
\end{tabular}

\section{Womens' observations}

\begin{tabular}{|c|c|c|c|}
\hline \multirow[t]{22}{*}{ Valpas 2004} & PGII at 1 year & $58.8 \%$ & $82.9 \%$ \\
\hline & Procedure met woman's expectation & $27.5 \%$ & $11.4 \%$ \\
\hline & - Completely & $7.8 \%$ & $0 \%$ \\
\hline & - Partially & $74.5 \%$ & $92.9 \%$ \\
\hline & - Not at all & & \\
\hline & Would recommend to a friend & $15.7 \%$ & $1.4 \%$ \\
\hline & - Yes & $3.9 \%$ & $0 \%$ \\
\hline & - Maybe & $64.7 \%$ & $71.4 \%$ \\
\hline & - No & $21.6 \%$ & $7.1 \%$ \\
\hline & PGII at 3 years & $5.9 \%$ & $0 \%$ \\
\hline & Procedure met woman's expectation & $76.5 \%$ & $77.1 \%$ \\
\hline & - Completely & $9.8 \%$ & $2.9 \%$ \\
\hline & - Not at all & $3.9 \%$ & $0 \%$ \\
\hline & Would recommend to a friend & $51.0 \%$ & $64.3 \%$ \\
\hline & - Yes & $23.5 \%$ & $8.6 \%$ \\
\hline & - Maybe & $3.9 \%$ & $0 \%$ \\
\hline & - No & & \\
\hline & PGII at 5 years & $66.7 \%$ & $67.1 \%$ \\
\hline & Procedure met woman's expectation & $7.8 \%$ & $23.5 \%$ \\
\hline & - Completely & $5.9 \%$ & $3.9 \%$ \\
\hline & - Partially & & \\
\hline & - Not at all & & \\
\hline
\end{tabular}


Table 2. Additional data: laparoscopic colposuspension versus midurethral slings (Continued) Would recommend to a friend

- Yes

- Maybe

- No

\begin{tabular}{|c|c|c|c|}
\hline Valpas 2004 & UISSa (0-20; mean, SD at 5 years) & $3.4(4.0)$ & $1.8(3.4)$ \\
\hline \multicolumn{4}{|l|}{ Surgical costs } \\
\hline Maher 2004 & & AUD 3388 & AUD 3633 \\
\hline Paraiso 2004 & & lap USD 6368 & USD 6059 \\
\hline Persson 2000 & & EUR 1273.40 & EUR 1342.80 \\
\hline Valpas 2004 & & EUR 1342.80 & EUR 1180.10 \\
\hline \multicolumn{4}{|c|}{ Mean duration of catheterisation } \\
\hline Maher 2004 & & 2.7 days $(2.6)$ & 1.4 days $(2.1)$ \\
\hline Paraiso 2004 & & lap 4.9 days & 5.2 days \\
\hline Ustun 2003 & & 3 days (range $1-5$ ) & 1 days (range $0-7$ ) \\
\hline Valpas 2004 & & $24.4 \mathrm{~h}$ & $9.2 \mathrm{~h}$ \\
\hline
\end{tabular}

IIQ: Incontinence Impact Questionnaire;ISI: Incontinence Symptom Index; I-QOL: Incontinence Quality of Life; PGII: Patients' Global Impression of Improvement; SD: standard deviation; SF-36: short-form 36 item health survey; SIIQ: Short Incontinence Impact Questionnaire; SUDI: Short Urinary Distress Inventory; UDI: Urogenital Distress Inventory; UISS: Urinary Incontinence Severity Score; YQ: York Quality of life

$a_{\text {Lower score }}=$ greater quality of life.

\section{AP PEN DICES}

\section{Appendix 1. Search strategy for clinical effectiveness studies: Cochrane Incontinence Specialised Register}

We searched the Cochrane Incontinence Specialised Register on 22 May 2019 using the Group's own keyword system, with the following search terms:

(design.rct* or design.cct*)

AND

TOPIC.URINE.INCON*

AND

INTVENT.SURG.LAP*

All searches were of the keywords field of EndNote 2018.

\section{Appendix 2. Electronic search methods for the brief economic commentary (BEC)}

We performed supplementary electronic searches designed to identify published reports of relevant economic evaluations to inform development of the brief economic commentary (BEC). We searched the following databases:

- MEDLINE on OvidSP (covering 1 January 1946 to week 5 July 2018) searched on 10 August 2018;

- Embase on OvidSP (covering 1 January 1980 to week 32 2018) searched on 10 August 2018; 
- NHS Economic Evaluation Database (NHS EED) on OvidSP (1st quarter 2016) searched on 6 April 2017 (this database is no longer updated by the producer).

The economic evaluation search filters applied to our MEDLINE and Embase search strategies for the BEC (reproduced below) are those formerly used by the UK Centre for Reviews and Dissemination (CRD) to identify published reports of full economic evaluations for indexing on NHS EED. These economic evaluation search filters remain freely available on the CRD Databases web-pages (CRD 2015). The other lines of search syntax in these MEDLINE and Embase search strategies for the BEC are those developed by one of the two health economists involved in the 2016 NIHR-funded project to add BECs to the suite of Cochrane Reviews involving surgery for urinary incontinence (Patricia Aluko). Terms describing the population and interventions were developed using both controlled vocabulary and textwords. We used one search strategy in NHS EED (OvidSP) and two different search strategies on MEDLINE and Embase (OvidSP). Details of the searches run and the search terms used can be found below.

\section{MEDLINE on OvidSP (1 January 1946 to week 5 July 2018) and Embase on OvidSP (1 January 1980 to week 32 2018) searched on 10 August 2018}

We used two different search strategies in MEDLINE and Embase (OvidSP).

\section{Search strategy 1}

1. Economics, Pharmaceutical/ or Economics, Medical/ or Economics/ or Economics, Hospital/ or economics.mp. or Economics, Nursing/

2. exp "costs and cost analysis"/

3. "Value of Life"/

4. exp "fees and charges"/

5. exp budgets/

6. budget $^{\star} . \mathrm{ti}, \mathrm{ab} .0$

7. cost $^{\star}$.ti.

8. (economic* or pharmaco?economic*).ti.

9. (price* or pricing*).ti,ab.

10. $\left(\right.$ cost $^{\star}$ adj2 (effective ${ }^{\star}$ or utilit ${ }^{\star}$ or benefit ${ }^{\star}$ or minimi ${ }^{\star}$ or unit $^{\star}$ or estimat ${ }^{\star}$ or variable $\left.^{\star}\right)$ ).ab.

11. (financ* or fee or fees).ti,ab.

12. (value adj2 (money or monetary)).ti,ab.

13. ((energy or oxygen) adj cost).ti,ab.

14. (metabolic adj cost).ti,ab.

15. ((energy or oxygen) adj expenditure).ti,ab.

16.1 or 2 or 3 or 4 or 5 or 6 or 7 or 8 or 9 or 10 or 11 or 12 or 13 or 14 or 15

17. exp Urinary Incontinence/

18. ((stress ${ }^{\star}$ or mix* or urg ${ }^{\star}$ or urin $\left.{ }^{\star}\right)$ adj3 incontinen $\left.{ }^{\star}\right)$.tw.

19. Urodynamics/ or Urinary Incontinence, Stress/ or Urinary Incontinence/ or Suburethral Slings/ or mixed incontinence.mp. or Urinary Bladder/ or Urinary Incontinence, Urge/

\section{17 or 18 or 19}

21. anterior vaginal repair*.tw.

22. 16 and 20 and 21

23. anterior colporrhaphy*.tw.

24. 21 or 23 
25. 16 and 20 and 23

26. bladder neck needle suspension\$.tw.

27. 16 and 20

\section{26 and 27}

29. open abdominal retropubic colposuspension ${ }^{\star}$.tw.

30. retropubic colposuspension ${ }^{\star}$.tw.

31. burch colposuspension*.tw.

32. 29 or 30 or 31

33. 27 and 32

34. laparoscopic retropubic colposuspension*.tw.

35. laparoscopic colposuspension*.tw.

36.34 or 35

37.27 and 36

38. traditional suburethral retropubic sling procedure $\$^{\star}$. tw.

39. traditional sling procedure $\$$.tw.

40. suburethral retropubic sling procedure $\$^{\star} . t w$.

41. retropubic sling procedure $\$$.tw.

42. traditional suburethral sling*.tw.

43. Suburethral Slings/ or Urinary Incontinence, Stress/ or Urologic Surgical Procedures/

44.27 and 43

45.21 or 23 or 26 or 32 or 36 or 38 or 39 or 40 or 41 or 42

46. suburethral slings/

47. urological surgical procedures/

48. 45 or 46 or 47

49. 48 and 27

50. remove duplicates from 49

\section{Search strategy 2}

1. economics.mp. [mp=ti, ab, ot, nm, hw, fx, kf, px, rx, ui, sy, tn, dm, mf, dv, kw, dq]

2. value of life.mp. [mp=ti, ab, ot, nm, hw, fx, kf, px, rx, ui, sy, tn, dm, mf, dv, kw, dq]

3. exp "costs and cost analysis"/

4. exp economics, hospital/

5. exp economics, medical/

6. economics, nursing.mp. [mp=ti, ab, ot, nm, hw, fx, kf, px, rx, ui, sy, tn, dm, mf, dv, kw, dq]

7. economics, pharmaceutical.mp. [mp=ti, ab, ot, nm, hw, fx, kf, px, rx, ui, sy, tn, dm, mf, dv, kw, dq]

8. exp "fees and charges"/ 
9. exp budgets/

10. budget $^{\star} . \mathrm{ti}, \mathrm{ab}$.

11. cost $^{\star}$.ti.

12. (economic ${ }^{\star}$ or pharmaco?economic $\left.{ }^{\star}\right)$.ti.

13. (price ${ }^{\star}$ or pricing*).ti,ab.

14. (cost $^{\star}$ adj2 (effective ${ }^{\star}$ or utilit ${ }^{\star}$ or benefit ${ }^{\star}$ or minimi ${ }^{\star}$ or unit ${ }^{\star}$ or estimat ${ }^{\star}$ or variable $\left.{ }^{\star}\right)$ ).ab.

15. (financ ${ }^{*}$ or fee or fees).ti,ab.

16. (value adj2 (money or monetary)).ti,ab.

17. or/1-16

18. economics.mp. [mp=ti, ab, ot, nm, hw, fx, kf, px, rx, ui, sy, tn, dm, mf, dv, kw, dq]

19. value of life.mp. [mp=ti, ab, ot, nm, hw, fx, kf, px, rx, ui, sy, tn, dm, mf, dv, kw, dq]

20. exp "costs and cost analysis"/

21. exp economics, hospital/

22. exp economics, medical/

23. economics, nursing.mp. [mp=ti, ab, ot, nm, hw, fx, kf, px, rx, ui, sy, tn, dm, mf, dv, kw, dq]

24. economics, pharmaceutical.mp. [mp=ti, ab, ot, nm, hw, fx, kf, px, rx, ui, sy, tn, dm, mf, dv, kw, dq]

25. exp "fees and charges"/

26. exp budgets/

27. budget $^{\star} . \mathrm{ti}, \mathrm{ab}$.

28. cost $^{\star}$. ti.

29. (economic ${ }^{\star}$ or pharmaco?economic $\left.{ }^{\star}\right)$.ti.

30. (price ${ }^{\star}$ or pricing $\left.{ }^{\star}\right)$.ti,ab.

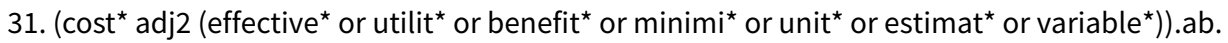

32. (financ* or fee or fees).ti,ab.

33. (value adj2 (money or monetary)).ti,ab.

34. 18 or 19 or 20 or 21 or 22 or 23 or 24 or 25 or 26 or 27 or 28 or 29 or 30 or 31 or 32 or 33

35. ((energy or oxygen) adj cost).ti,ab.

36. (metabolic adj cost).ti,ab.

37. ((energy or oxygen) adj expenditure).ti,ab.

38.34 or 35 or 36 or 37

39. urinary incontinence.mp. [mp=ti, ab, ot, nm, hw, fx, kf, px, rx, ui, sy, tn, dm, mf, dv, kw, dq]

40. ((stress\$ or mix\$ or urg\$ or urin\$) adj3 incontinen\$).tw.

41. URINARY INCONTINENCE, STRESS.mp. [mp=ti, ab, ot, nm, hw, fx, kf, px, rx, ui, sy, tn, dm, mf, dv, kw, dq]

42. stress urinary incontinence ${ }^{\star} . m p$. [mp=ti, ab, ot, nm, hw, fx, kf, px, rx, ui, sy, tn, dm, mf, dv, kw, dq]

43. 39 or 40 or 41 or 42 


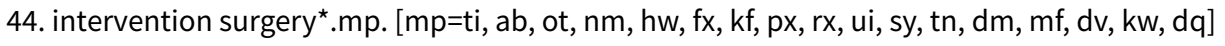

45. colporrhaphy.tw.

46. Bologna procedure*.mp. [mp=ti, ab, ot, nm, hw, fx, kf, px, rx, ui, sy, tn, dm, mf, dv, kw, dq]

47. Kelly-Kennedy.mp. [mp=ti, ab, ot, nm, hw, fx, kf, px, rx, ui, sy, tn, dm, mf, dv, kw, dq]

48. Marion Kelly.mp. [mp=ti, ab, ot, nm, hw, fx, kf, px, rx, ui, sy, tn, dm, mf, dv, kw, dq]

49. Diaphragmplasty.mp. [mp=ti, ab, ot, nm, hw, fx, kf, px, rx, ui, sy, tn, dm, mf, dv, kw, dq]

50. Vaginal urethrocystopexy.mp. [mp=ti, ab, ot, nm, hw, fx, kf, px, rx, ui, sy, tn, dm, mf, dv, kw, dq]

51. Cystocele repair.mp. [mp=ti, ab, ot, nm, hw, fx, kf, px, rx, ui, sy, tn, dm, mf, dv, kw, dq]

52. Kelly plication.mp. [mp=ti, ab, ot, nm, hw, fx, kf, px, rx, ui, sy, tn, dm, mf, dv, kw, dq]

53. anterior vaginal repair\$.mp. [mp=ti, ab, ot, nm, hw, fx, kf, px, rx, ui, sy, tn, dm, mf, dv, kw, dq]

54. anterior colporrhaphy.mp. [mp=ti, ab, ot, nm, hw, fx, kf, px, rx, ui, sy, tn, dm, mf, dv, kw, dq]

55.44 or 45 or 46 or 47 or 48 or 49 or 50 or 51 or 52 or 53 or 54

56. 38 and 43 and 55

57. remove duplicates from 56

58. Bladder neck needle suspension\$.mp. [mp=ti, ab, ot, nm, hw, fx, kf, px, rx, ui, sy, tn, dm, mf, dv, kw, dq]

59. 38 and 43 and 58

60. burch colposuspension.mp. [mp=ti, ab, ot, nm, hw, fx, kf, px, rx, ui, sy, tn, dm, mf, dv, kw, dq]

61. open abdominal retropubic colposuspension.mp. [mp=ti, ab, ot, nm, hw, fx, kf, px, rx, ui, sy, tn, dm, mf, dv, kw, dq]

62. Paravaginal defect repair.mp. [mp=ti, ab, ot, nm, hw, fx, kf, px, rx, ui, sy, tn, dm, mf, dv, kw, dq]

63. Marshall-Marchetti-Krantz.mp. [mp=ti, ab, ot, nm, hw, fx, kf, px, rx, ui, sy, tn, dm, mf, dv, kw, dq]

64. abdominal burch.mp. [mp=ti, ab, ot, nm, hw, fx, kf, px, rx, ui, sy, tn, dm, mf, dv, kw, dq]

65. abdominal colposuspension.mp. [mp=ti, ab, ot, nm, hw, fx, kf, px, rx, ui, sy, tn, dm, mf, dv, kw, dq]

66. endopelvic Fascia Plication.mp. [mp=ti, ab, ot, nm, hw, fx, kf, px, rx, ui, sy, tn, dm, mf, dv, kw, dq]

67.60 or 61 or 62 or 63 or 64 or 65 or 66

68.38 and 43

69.67 and 68

70. laparoscopic retropubic colposuspension.mp. [mp=ti, ab, ot, nm, hw, fx, kf, px, rx, ui, sy, tn, dm, mf, dv, kw, dq]

71. laparoscopic colposuspension.mp. [mp=ti, ab, ot, nm, hw, fx, kf, px, rx, ui, sy, tn, dm, mf, dv, kw, dq]

72. retropubic colposuspension.mp. [mp=ti, ab, ot, nm, hw, fx, kf, px, rx, ui, sy, tn, dm, mf, dv, kw, dq]

73. 70 or 71 or 72

74.68 and 73

75. remove duplicates from 74

76. suburethral sling.mp. [mp=ti, ab, ot, nm, hw, fx, kf, px, rx, ui, sy, tn, dm, mf, dv, kw, dq]

77. abdominal sling.mp. [mp=ti, ab, ot, nm, hw, fx, kf, px, rx, ui, sy, tn, dm, mf, dv, kw, dq]

78. traditional sling procedure $\$$.tw. 
79. suburethral sling procedure.mp. [mp=ti, ab, ot, nm, hw, fx, kf, px, rx, ui, sy, tn, dm, mf, dv, kw, dq]

80.76 or 77 or 78 or 79

81.68 and 80

82. remove duplicates from 81

83. mid\$urethral sling.mp. [mp=ti, ab, ot, nm, hw, fx, kf, px, rx, ui, sy, tn, dm, mf, dv, kw, dq]

84. retropubic sling procedure $\$$.tw.

85. transobturator sling procedure\$.mp. [mp=ti, ab, ot, nm, hw, fx, kf, px, rx, ui, sy, tn, dm, mf, dv, kw, dq]

86.83 or 84 or 85

87. remove duplicates from 86

88.68 and 87

89. TVT-Secur.mp. [mp=ti, ab, ot, nm, hw, fx, kf, px, rx, ui, sy, tn, dm, mf, dv, kw, dq]

90. mini-arc.mp. [mp=ti, ab, ot, nm, hw, fx, kf, px, rx, ui, sy, tn, dm, mf, dv, kw, dq]

91. ajust.mp. [mp=ti, ab, ot, nm, hw, fx, kf, px, rx, ui, sy, tn, dm, mf, dv, kw, dq]

92. needleless.mp. [mp=ti, ab, ot, nm, hw, fx, kf, px, rx, ui, sy, tn, dm, mf, dv, kw, dq]

93. solyx.mp. [mp=ti, ab, ot, nm, hw, fx, kf, px, rx, ui, sy, tn, dm, mf, dv, kw, dq]

94. single\$incision sling\$.mp. [mp=ti, ab, ot, nm, hw, fx, kf, px, rx, ui, sy, tn, dm, mf, dv, kw, dq]

95. miniarc.mp. [mp=ti, ab, ot, nm, hw, fx, kf, px, rx, ui, sy, tn, dm, mf, dv, kw, dq]

96. mini\$sling.mp. [mp=ti, ab, ot, nm, hw, fx, kf, px, rx, ui, sy, tn, dm, mf, dv, kw, dq]

97. Ophira.mp. [mp=ti, ab, ot, nm, hw, fx, kf, px, rx, ui, sy, tn, dm, mf, dv, kw, dq]

98. Tissue Fixation System.mp. [mp=ti, ab, ot, nm, hw, fx, kf, px, rx, ui, sy, tn, dm, mf, dv, kw, dq]

99. 89 or 90 or 91 or 92 or 93 or 94 or 95 or 96 or 97 or 98

100. 68 and 99

101. remove duplicates from 100

102. ((urethra\$ or periurethra\$ or transurethra\$) adj3 (agent\$ or bulk\$ or injection\$ or injectable\$)).tw.

103. injection therapy.tw.

104. injectable\$.tw.

105. (injectable\$ adj2 agent\$).tw.

106. (bulk\$ adj3 agent\$).tw.

107. Peri\$urethral injection\$.mp. [mp=ti, ab, ot, nm, hw, fx, kf, px, rx, ui, sy, tn, dm, mf, dv, kw, dq]

108. Autologous fat.mp. [mp=ti, ab, ot, nm, hw, fx, kf, px, rx, ui, sy, tn, dm, mf, dv, kw, dq]

109. Macroplastique.mp. [mp=ti, ab, ot, nm, hw, fx, kf, px, rx, ui, sy, tn, dm, mf, dv, kw, dq]

110. Calcium hydroxylapatite.mp. [mp=ti, ab, ot, nm, hw, fx, kf, px, rx, ui, sy, tn, dm, mf, dv, kw, dq]

111. Hyaluronic acid with dextranomer.mp. [mp=ti, ab, ot, nm, hw, fx, kf, px, rx, ui, sy, tn, dm, mf, dv, kw, dq]

112. Porcine dermal implant.mp. [mp=ti, ab, ot, nm, hw, fx, kf, px, rx, ui, sy, tn, dm, mf, dv, kw, dq]

113. Ethylene vinyl alcohol copolymer.mp. [mp=ti, ab, ot, nm, hw, fx, kf, px, rx, ui, sy, tn, dm, mf, dv, kw, dq] 
114. Silicon particles.mp. [mp=ti, ab, ot, nm, hw, fx, kf, px, rx, ui, sy, tn, dm, mf, dv, kw, dq]

115.102 or 103 or 104 or 105 or 106 or 107 or 108 or 109 or 110 or 111 or 112 or 113 or 114

116.102 or 103 or 104 or 105 or 106 or 107 or 108 or 109 or 110 or 111 or 112 or 113 or 114

117.68 and 115

118.55 or 58 or 67 or 73 or 80 or 86 or 99 or 115

119. 118 and 38 and 43

120. remove duplicates from 119

\section{NHS EED (OvidSP) (1st quarter 2016)}

NHS Economic Evaluation Database (NHS EED) on OvidSP (1st Quarter 2016) searched on 6 April 2017. As this database is no longer updated by the producer we did not perform further updates of this search as no new records would have been added.

We searched NHS EED using the following search strategy:

1. Urinary incontinence/

2. Urinary incontinence, stress/

3. ((stress\$ or mix\$ or urg\$ or urin\$) adj3 incontinen\$).tw.

4. Colporrhaphy.tw.

5. Colpoperineoplast\$়.tw.

6. Sling procedure\$.tw.

7. Sling\$ procedure\$.tw.

8. Bladder neck needle suspension\$.tw.

9. Anterior vaginal repair\$.tw.

10. Or/1-9

Appendix 3. Contributions to previous versions and acknowledgements

\section{Contributions of authors}

For the original review (Moehrer 2000): Birgit Moehrer wrote the review with advice and editorial help from Don Wilson. Don Wilson and Marcus Carey wrote the original protocol. Gaye Ellis and Birgit Moehrer selected trials, extracted data separately and cross-checked with Don Wilson.

For the first (2005), second (2007) and third (2009) updates: Nicola Dean wrote the updated review. Gaye Ellis and Nicola Dean assessed the new studies and extracted the data separately. Don Wilson and Peter Herbison checked the new data and commented on the review.

\section{Acknowledgements}

For the original review (Moehrer 2000): Jean Hay-Smith, Peter Herbison and Gaye Ellis were very helpful with discussions on the form of the review, data interpretation and trial selection. Michelle Fynes critically read and commented on the final draft of the original review.

For the 2007 update: we would like to thank the previous authors, Birgit Moehrer and Marcus Carey, for their contributions to the original review.

\section{WHAT'S NEW}

\begin{tabular}{lll}
\hline Date & Event & Description \\
\hline 6 December 2019 & New search has been performed & $\begin{array}{l}\text { For this update, published in 2019, we made the following } \\
\text { changes. }\end{array}$
\end{tabular}




\begin{tabular}{lll}
\hline Date Event Description & Den
\end{tabular}

1. We updated the search to May 2019 and added five new trials

(Carey 2006; Samiee 2009; Stangel-Wojcikiewicz 2008; Tuygun 2006; Ustun 2005), bringing the total to 26.

2. We changed the primary outcome from 'number of women with incontinence' to 'subjective cure of incontinence'.

3. We created subgroup analyses for the different surgical techniques used in laparoscopic colposuspension.

4. In accordance with Cochrane standards, we performed a full risk of bias assessment on all trials and evaluated the quality of the evidence by adopting the GRADE approach.

\section{December 2019}

New citation required but conclusions have not changed
1. There are changes to the byline.

\section{HISTORY}

Protocol first published: Issue 3, 2001

Review first published: Issue 1, 2002

\begin{tabular}{lll}
\hline Date & Event & Description \\
\hline 10 July 2017 & Amended & $\begin{array}{l}\text { Brief economic commentary (BEC) added. Economics-related } \\
\text { sections revised: the Abstract, Plain language summary, Back- } \\
\text { ground, Methods (outcomes, search methods), and Discussion } \\
\text { were amended. Appendix added with details of search strategies } \\
\text { for BECs. }\end{array}$ \\
\end{tabular}

16 December $2009 \quad$ New search has been performed

Minor update. This updated review includes the long term (4 to 8 years) follow-up results of a previously included trial, comparing laparoscopic colposuspension and TVT. Overall four studies were identified from the search. Two trials were excluded due to not being randomised and a further study, which was in abstract form, had already been included in the previous updated review in 2007. So only one study has been added in this update. This is the long term (4 to 8 years) follow-up results of a previously included trial, comparing laparoscopic colposuspension and TVT. Overall the conclusions of the review remain the same, with now emerging evidence that laparoscopic colposuspension has similar long-term subjective cure rates as TVT.

31 October $2007 \quad$ New citation required and conclusions have changed
Substantive amendment This update of the review (Jan 2008) includes additional results from a three-armed trial comparing two techniques of laparoscopic colposuspension with open colposuspension. Many of the trials in the previously updated review were in abstract form only and now have been published in full and on one occassion the authorship has changed. One trial has also published additional outcomes of cost effectiveness. The overall conclusions of the review remain unchanged for the comparisons of laparoscopic colposuspension with open and newer sling techniques. However, the addition of the three armed trial has lead to both subjective and objective outcomes favouring the use of sutures rather than mesh for the laparoscopic colposuspension procedures.

The last major update of the review (Jan 2006) included the following:
24 May $2006 \quad$ New citation required and conclusions have changed 


\begin{tabular}{lll}
\hline Date Event Description & Den
\end{tabular}

The authorship has changed. Nicola Dean and Peter Herbison have been added to the authors, in place of Birgit Moehrer and Marcus Carey.

The review includes the results of thirteen extra trials.

Four trials compared laparoscopic colposuspension with open colposuspension, involving longer-term follow-up data and additional outcomes, such as health economic costs and quality of life scores.

Eight trials have been included comparing laparoscopic colposuspension with 'self-fixing' vaginal sling procedures, reporting short-term outcomes and allowing for analysis.

There is one additional trial comparing techniques of laparoscopic colposupension.

The overall conclusion that laparoscopic colposuspension appears, in the short-term, to have similar subjective and poorer objective cure rates to open colposuspension remains. However, 'self fixing' sling procedures appear to have similar, if not, better cure rates than laparoscopic colposuspension and offer greater benefits of minimal access surgery: shorter operation time, shorter hospital stay, and quicker return to normal activities.

15 January $2002 \quad$ New search has been performed $\quad$ update

\section{CONTRIBUTIONS OF AUTHORS}

JF: initial screening of studies for inclusion into this update, data extraction, 'Risk of bias' assessment, data analysis and interpretation, writing the review

FS: data extraction, 'Risk of bias' assessment, data analysis and interpretation, writing the review

MIO: data extraction, 'Risk of bias' assessment, data analysis and interpretation, providing methodological guidance, writing the review AM: conduct and writing of brief economic commentary

WA: initial screening of studies for inclusion into this update, data extraction, 'Risk of bias' assessment, data analysis and interpretation, writing the review, providing clinical guidance

\section{DECLARATIONS OF INTEREST}

JF: none known

FS: none known

MIO: none known

AM: none known

WA: Wael Agur has received a Research Fellowship from the Chief Scientist Office, NHS Research Scotland and support for travel to meetings from the University of Aberdeen; trainer and speaker fees from CR Bard for training surgeons on mesh procedures for incontinence and prolapse, sponsorship from Boston Scientific for training on mesh procedures for prolapse, sponsorship from Neomedic for training on mesh procedures for incontinence, trainer and speaker fees from SEP Pharma/Contura, NHS Ayrshire \& Arran, and the London Medical Education Academy for cadaver training on native tissue continence surgery, including laparoscopic colposuspension; consultancy fees from Astellas and SEP Pharma/Contura; expert fees from the Central Legal Office of NHS Scotland and various law firms in Scotland, England, USA, the Republic of Ireland and Australia for provision of medicolegal advice, expert report writing and/or appearance in court, on mesh litigation; and institutional research support as principal investigator for the SIMS pilot studies, PROSPECT, VUE, POPPY, OPAL, TOPSY and PURSUIT studies.

\section{SOURCES OF SUPPORT}

\section{Internal sources}

- No sources of support supplied 


\section{External sources}

- National Institute for Health Research, UK.

This project was supported by the National Institute for Health Research, via Cochrane Infrastructure funding to Cochrane Incontinence. The views and opinions expressed therein are those of the authors and do not necessarily reflect those of the Systematic Reviews Programme, NIHR, NHS or the Department of Health. The NIHR Cochrane Infrastructure grant is the single largest funder of Cochrane Incontinence.

\section{DIFFERENCES BETWEEN PROTOCOLAND REVIEW}

In this update of the review (2019), we made the following changes:

- Performed a full 'Risk of bias' assessment of all included trials;

- Developed 'Summary of findings' tables and adopted the GRADE method (Guyatt 2008) to assess quality of evidence;

- Substantively revised, updated and reformatted the review, including the Data collection and analysis section, in accordance with current Cochrane standards;

- Created subgroup analyses for the different surgical techniques used in laparoscopic colposuspension; and

- Changed the primary outcome from number of women with incontinence to subjective cure of incontinence.

\section{NDEX TERMS}

\section{Medical Subject Headings (MeSH)}

*Laparoscopy; Quality of Life; Randomized Controlled Trials as Topic; Urinary Incontinence [*surgery]; Urologic Surgical Procedures [methods]

\section{MeSH check words}

Female; Humans 